\title{
Charles Ruys de Beerenbrouck : edelman-staatsman, 1873-1936
}

Citation for published version (APA):

Stassen, M. J. L. A. (2000). Charles Ruys de Beerenbrouck : edelman-staatsman, 1873-1936. [Doctoral Thesis, Maastricht University]. Datawyse / Universitaire Pers Maastricht. https://doi.org/10.26481/dis.20000628ms

Document status and date:

Published: 01/01/2000

DOI:

10.26481/dis.20000628ms

Document Version:

Publisher's PDF, also known as Version of record

\section{Please check the document version of this publication:}

- A submitted manuscript is the version of the article upon submission and before peer-review. There can be important differences between the submitted version and the official published version of record.

People interested in the research are advised to contact the author for the final version of the publication, or visit the DOI to the publisher's website.

- The final author version and the galley proof are versions of the publication after peer review.

- The final published version features the final layout of the paper including the volume, issue and page numbers.

Link to publication

\footnotetext{
General rights rights.

- You may freely distribute the URL identifying the publication in the public portal. please follow below link for the End User Agreement:

www.umlib.nl/taverne-license

Take down policy

If you believe that this document breaches copyright please contact us at:

repository@maastrichtuniversity.nl

providing details and we will investigate your claim.
}

Copyright and moral rights for the publications made accessible in the public portal are retained by the authors and/or other copyright owners and it is a condition of accessing publications that users recognise and abide by the legal requirements associated with these

- Users may download and print one copy of any publication from the public portal for the purpose of private study or research.

- You may not further distribute the material or use it for any profit-making activity or commercial gain

If the publication is distributed under the terms of Article $25 \mathrm{fa}$ of the Dutch Copyright Act, indicated by the "Taverne" license above, 
(c) 2000 M.J.L.A. Stassen, Munstergeleen, The Netherlands All rights reserved. No part of this publication may be reproduced or transmitted in any form or by any means, electronic or mechanical, including photocopy, recording or any informationstorage or retrieval system, without permission in writing from the copyright owner.

ISBN: 9090138374

Vormgeving: Caroline Stassen

Productie en druk: Datawyse | Universitaire Pers Maastricht 


\section{CHARLES RUYS DE BEERENBROUCK edelman - staatsman 1873 - 1936}

\section{Proefschrift}

ter verkrijging van de graad van doctor aan de Universiteit Maastricht, op gezag van de Rector Magnificus, Prof. dr. A.C. Nieuwenhuijzen Kruseman, volgens het besluit van het College van Decanen in het openbaar te verdedigen op woensdag 28 juni 2000 om 16.00 uur door

Jo Stassen 


\section{Promotores:}

Prof. mr. F.A.M. Stroink

Prof. mr. A.W. Heringa

\section{Beoordelingscommissie:}

Prof, mr. L.F.M. Verhey (voorzitter)

Prof. mr. D.j. Elzinga (Rijksuniversiteit Groningen)

Prof. mr. E.C.M. Jurgens 


\section{INHOUD}

WOORD VOORAF

\section{HOOFDSTUK 1}

Terugblik en vooruitzicht

1.1 Inleiding

1.2 De liberale staatsinrichting

De grondwet wan $1848,7 /$ Monumentaal startpunt, 7

1.3 Nagalm van het ancien régime

1.4 Fundamentele strijdvragen

De onderwijskwestie, $9 /$ Het kiesrechtvradgstuk, 10/Kappeyne speelt met vuur, $11 /$ De grondwetsherziening van $1887,12 /$ Het eerste rechtse coalitiekabinet, 13/Takkianen versus anti-Takkianen, 13/Politieke hergroepering. 14/ Het "slaven/uk" van de leerplicht, 15/Antithesepolitiek van Kuyper, $16 /$ Poging tor herzlening wan de grondwet, $16 /$ Paciflcator tussen rechts en links, 17

1.5 Van staatsonthouding tot staatsinterventle Schoorvotende staatsbemoeing. 19

\section{HOOFDSTUK 2}

De kabinetsformatie van 1918

\subsection{Inleiding}

2.2 Rechts coalitieverbond staat op springen

De Tweede-Kamerverkiezing van 1918,22, Protestantse dilemma's, 23

2.3 Nolens formateur

Eén vulltie aan de lucht, 24/Tussenberaad, 26 
2.4 Ruys rondt af

Ridder of schildknatp? 28

\section{HOOFDSTUK 3}

Charles Ruys, adel verplicht

3.1 Inllelding

3.2 leugd en studletijd

3.3 Soclaal en polltiek dubbelleven

HOOFDSTUK 4

Het eerste kabinet-Ruys de Beerenbrouck 1918-1922

4.1 Inlelding

Samenstelling wan de ministersplaeg, 35

4.2 Vuurdoop

Nadagen van de oorlog. 37/Revolutionair klimaat, 39/Manlfest wan SDAP en NVW' 40/Traelstra's revolutionalre kamerrede, 40/Reactie van de kamer en Ruys, 42 / Vreugde over de goede afloop, 44

4.3 Het kabinetsdebuut in het licht van het staatsrecht

Versterking van het premierschap, 46/De koninklijke onschendbaarheid, $48 /$ Constitutie en revolutie, 49

4.4 De elsen van de nieuwe tijd

Het ropjaar van de sochale wetgeving, 5I/Actief wrouwenkiesrecht, $55 /$ Schoolwet-De Visser, 57

4.5 Het kabinet in de problemen

Pappen en nat gaan. 6I/ Een bedroevend zootje. 62

4.6 De reconstructie van 1921

Missie- en zendingsirbeid, 68

4.7 De echo van de Volkenbond

Vraagstukken van hogere politieke orde, $7 /$ / Herziening van de kieswet, 72 
4 De grondwetsherzlening van 1922

Wat verandert, 74 / De woed in ebbe werkerd. $76 /$ Een sprookle afschatfen?.77

4.9 Balans van wer jaar Ruys

HOOFDSTUK 5

De kbinetsfomatte van 1922

5. Intetoling

Het kabinet bitfit altten, $86 /$ De koningh consulteent, $87 / \mathrm{De}$ Geer informatewt 88

5.2 Ruys formatev

De Vaticaankwestle, $90 / 0 p$ zoel naar een gemeenschappelltke basts,

9l/ Het regeerakkoord, 93

\section{HOOFDSTUK 6}

Het weede kabinet-Ruys de Beerenbrouck 1922-1925

6. Inlelding

6.2 Bezunigingspolthek

Narlgheld in het werschet, 99

6.3 Een kindsdeel en nog veel meer

Leven en laten leven, $102 /$ Beklaggde promovert to werdachte $103 /$ De weg has arbeldswede, $104 /$ Het belang wan de landbouw wint veld, $105 /$ Organieke regelingen, 106

6.4 De eerste schermutsellngen

De sterke man in actie, 110

6.5 Nolens en ziln rebellenclub

Een krachieloos machiswoord, 1/3/ Virtueel viootakkoord, /14

6.6 Het latste redmiddel

De formatiepoging van Koolen, $1 / 6 /$ /Jdele hoop, $1 / 7 /$ De rechterzljde voor het blok, $1 / 8$ 
6.7 Gelukkig dat Ruys er nog is

A/s feilt aanvalard, 120

6.8 Het waagstuk loopt goed af

Tegen alle "verkregen rechten" in, 123,/ De finale wan het politieke bectrlf, 125

6.9 Balans van drie jaar Ruys If

\section{HOOFDSTUK 7}

Een lang intermezzo na een korte proloog 1925-1929

7.1 Inlelding

7.2 Onder het presidlaat wan Ruys

De nacht van Kersten, 130/Rechts coalitieverbond ter ziele, 131/Ruys en de reorganisatte van de staatspartij, 132

7.3 Een intermezzokabinet

Kosmopolleten in natm, 135

7.4 De kabinetsformatie van 1929

\section{HOOFDSTUK 8}

Het derde kabinet-Ruys de Beerenbrouck 1929-1933

8.1 Inleiding

8.2 Nlet zargwekkend, wel zorgeisend

Etketten opplakken, 144

8.3 Een goed begin

Geen funshoppen op zondag, $148 /$ Etherrantsoen, $449 /$ De gemeentewet herzien, 151

8.4 De kentering

Tasten en zoeken, 153

8.5 Het malaise|aar 1931

pachtrecht in crisistijd, 156/Smerige, ellendige troep, 15\%/Aanpassing 
aan de verminderde welvaart, $162 /$ Het eind van een tijdperk, 164

8.6 Wegwelteren

Uit bittere noodzaak, $167 /$ Een nationale wet, $170 /$ Instrumenten voor de crisisbestriliding, $172 / \mathrm{De}$ initiatiefwet van Ebels, 175

8.7 Duistere tijden

Den Haag in rep en roer, $176 /$ Het kabinet onder vur, $178 / \mathrm{Gelukkig}$ dat Ruys er nog is?. 180/Tot betere tijden, $181 / 100 k$ dat nog. $182 /$ Op termilin gesteld, 184

8.8 Balans van wher jaar Ruys III

186

HOOFDSTUK 9

189

De slotjaren \933-1936

9.1 Inleilding

9.2 Snipperuurtjes goed bestedien

9.3 Leven zonder te werken, dat kan ik niet

9.4 Betekenis van Ruys 



\section{WOORD VOORAF}

Gedurende 31 jaar heeft jhr. mr. Charles Joseph Marie Ruys de Beerenbrouck (1873-1936) ons land in de voorste gelederen gediend.

In 1905 verschijnt Charles Ruys op het landelijke politieke toneel. Hij maakt in dat jaar zijn debuut in de Tweede Kamer en is daar tot in 1918 onafgebroken lid van. Na dit optreden speelt hili alleen nog maar hoofdrollen. Beurtelings is hij tot aan zijn dood in 1936 voorzitter van de ministerraad en voorzitter van de Tweede Kamer. Bil elkaar staat Ruys in de boeken als een staatsman die twintig jaar lid - waarvan zeven jaar voorzitter - van die kamer is geweest en liefst drie kabinetten heeft geleid.

Als Nederland op 9 september 1918 in de persoon van de Limburger Ruys voor het eerst een katholieke premier krijgt, is die gebeurtenis niet minder dan een schokkende doorbraak van de tot dan toe bestaande politieke verhoudingen. Met een premierschap van bijna elf jaar is hij de langst regerende eerste minister uit onze parlementaire geschledenis, tòt Ruud Lubbers dit record zo'n zestig jaar later breekt.

De tijd waarin de opmerkelijke Haagse loopbaan van Ruys zich afspeelt, is bepaald niet de meest vredige en onbewogen periode van de twintigste eeuw: de ruim vier jaar durende teistering van de Eerste Wereldoorlog met zijn nasleep van ellende, de commotie rond de revolutiepoging van Troelstra, de strijd om de sociale hervorming, de herziening van de grondwet, de ontwapeningsgolf met haar verlammende werking op de landsverdedlging, de dreiging van het opkomende fascisme en nationaal-socialisme, alsook de economische neergang en crisis van de jaren twintig en dertig zijn slechts een greep uit de moeilijke opgaven waarvoor hij komt te staan.

Wie is Ruys, waardoor kenmerken zich zljn denken, daden en politieke kwaliteiten en wat heeft deze man ons nagelaten, die op cruciale momenten in het staatkundige en maatschappelijke leven van ons land aan het roer staat, zijn enkele vragen die niet onbeantwoord mogen blijven, wil men de band die hem met zijn tijd verbindt op de juiste waarde schatten. Dankzij eerder verrichte studies ' $k a n$ men zich een helder beeld vormen van politici uit die tijd als: dr. Abraham Kuyper (1837-1920), jhr. mr. Alexander Frederik de Savornin Lohman (1837-1924), mr. Pleter Jelles Troelstra (1860-1930), mgr. dr. Willem Hubert Nolens (1860-1931), mr. Theodorus Heemskerk (1852-1932), mr. Pieter Wilhelm Adriaan Cort van 
der Linden (1846-1935), dr. Hendrikus Colijn (1869-1944), mr. Petrus Josephus Mattheus Aalberse (1871-1948), mr. Hendrik Pieter Marchant (1869-1956) en veel andere prominenten.

Ruys ontbreekt in dit rijtje. In tegenstelling tot een extreem vereerde en daarnaast even grondig verafschuwde man als de wat pompeuze, theatrale Collin, die nog steeds voortleeft in het publieke geheugen en tot de dag van vandaag veel stof tot schrijven geeft ${ }^{2}$, brengt de ingetogen, ongekunstelde Ruys de pennen nauwelijks in beweging. ${ }^{3}$ Zijn lijfspreuk: "nooit versagend, nooit onbescheiden", getuigt van deugden die lemand welhaast tot de vergetelheid doemen.

Even ontwaakt de sluimerende herinnering aan Ruys. Bij gelegenheid van zljn $25^{\text {ste }}$ sterfdag ontstaat het plan om deze respectabele staatsman een late hulde te brengen: Nederland en vooral Limburg zijn hem nog een standbeeld schuldig !

De inlossing van die ereschuld heeft plaats op 27 mei 1967 als jkvw. Marla van Nispen tot Sevenaer-Ruys de Beerenbrouck een bronzen borstbeeld van haar vader aan de Calvariestraat in Maastricht onthult. Maar na deze kortstondige opleving van Ruys, verdwijnt langzamerhand de herinnering aan zijn politieke leven en nalatenschap.

Een onverwachte revival van Ruys kondigt zich aan als de Stichting Literaire Activiteiten Amsterdam in de jaren 1988-1990 een serie lezingen organiseert over achttien toppers van de twintigste eeuw, die waardig zijn bevonden om Jan en Annie Romeins portrettengalerij van zesendertig prealabele Erflaters van onze beschaving te completeren.

Geïnspireerd door Ruys' inzet voor de publieke zaak klest Lubbers voor een terugblik op zijn politieke erflater, wiens nalatenschap, aldus de toenmalige premier, uit drie hoofdelementen bestaat: de prioriteit die Ruys gaf aan sociale kwesties, zijn democratische beginselvastheid - van stemrecht voor een leder tot een grotere rol van de Tweede Kamer - en ten slotte zijn afkeer van het model van de sterke man. ${ }^{4}$

Sociale rechtvaardigheid? Verheffing van de arbeiders? Ruys sociaal bewogen, een emancipator? Dat zijn loze woorden en loze beloften uit de mond van katholieken, dat zijn leugens van Lubbers over Ruys, hoont $D e$ Groene Amsterdammer van 16 mel 1990 in reactie op Lubbers' lezing en aansluitend artikel in de Volkskrant van 23 februari 1990. Dat is niet misselijk, al zou een beetje weekblad moeten weten dat je door zo'n hoge toon aan te slaan jezelf behoorlijk te kijk zet, zonder de mikpunten van je verachting te raken ...

Met het oordeel van dr. G. Puchinger, voormalig hoofd van het Historisch Documentatiecentrum voor het Nederlands Protestantisme, dat Ruys 
door zijn kundigheden maar vooral door zijn eigenschappen van hoofd en hart, juist als eerste rooms-katholieke minister-president een zegen voor Nederland is geweest ${ }^{5}$, klappen we de drieluik vol verscheidenheid aan opvattingen over onze hoofdpersoon voorlopig dicht.

Kijkt men naar de grote hoeveelheid biografieën en andere publicatles die aan Nederlandse politici, ongeacht hun functies en formaat, zijn gewijd, dan valt des te meer op hoe zwaar onderbelicht Ruys is gebleven. Het is toch merkwaardig dat een man als Ruys, die het staatkundige en maatschappelijke leven van ons land op zo vooraanstaande posten zo langdurig en op zo belangrijke momenten heeft meebepaald, zo weinig belangstelling heeft gewekt, en nu voomamelijk zijn bekendheid ontleent aan een schriel gedenkzuiltje in Maastricht en aan naambordjes op zljstraten van een Thorbeckeplein of een Nolenslaan in de minst introverte gemeenten. ${ }^{6}$ Die ogenschijnlijke tegenstrijdigheid roept vragen op, noodt uit tot nader onderzoek naar de rol en de betekenis van Ruys.

Nadat het ontstaan van het eerste kabinet-Ruys in een terugblik op de politiek-maatschappelijke ontwikkelingen sedert de tweede helft van de negentiende eeuw is belicht, richt het onderzoek zich vervolgens op de belangrijkste situaties waarin Ruys zich als kabinetsleider of in andere hoedanigheid geplaatst ziet. In deze capita selecta is er met name ook ruime aandacht voor de wederkerige relatie van politiek en staatsrecht.

De meer persoonlijke kant van Ruys' leven komt niet anders dan terloops aan de orde.

De intentie van dit werk is bovenal de herinnering aan de staatsman Ruys ruim zestig jaar na zijn dood - nleuw leven in te blazen.

Als daardoor de waardering voor Ruys zou stijgen, is dat een mool neveneffect! 


\subsection{Inleiding}

In bijna heel Europa is 1848 een roerig jaar. De opgekropte weerzin tegen het stelsel van de Heilige Alliantie met zijn verlicht despotisme komt tot uitbarsting in een heftige vrijheidsbeweging. De gevestigde orde wordt opgerold door hervormingsgezinden.

In Nederland brengen de februarirevolutie in Parijs en de maartrevoluties in Wenen en Berlijn grote schrikreacties teweeg. Wil men bulten de woeste maalstroom blijven, dan valt aan hervormingen niet te ontkomen, beseft men nu ook in conservatieve kring. Voor de liberalen is het getil gunstig om de lang gekoesterde herzieningswensen binnen te halen en alzo de slepende strijd met de conservatieven in hun voordeel te beslechten.

Verhinderen elders in Europa sociale of nationalistische bewegingen dat de overwinning van de liberale revolutionairen van lange duur is " In Nederland krijgt de liberale burgeri] wèl de revolutie die haar voor ogen staat. Binnen zeven maanden heeft ons land een op liberale leest geschoeide staatsinrichting die de grote beroering die zich in andere landen voordoet, buiten de grenzen houdt.

De liberale staat is gevestigd en gaat de negentiende eeuw domineren. De conservatieven verliezen in 1848 de slag. Voortaan maken de liberalen de dienst uit. Tot in de jaren zeventig is de liberale partij zelfs oppermachtig. Maar ook in de periode daarna, als het liberalisme in verval is, drulken de liberalen nog een zwaar stempel op het politieke en maatschappelijke leven van ons land.

In die laatste kwarteeuw treden echter ingrijpende veranderingen in de staatkundige verhoudingen op. De liberale partij ontkomt niet aan een richtingenstrijd die het klassieke, doctrinaire Thorbecklaanse liberalisme en een meer democratische, radicale stroming uiteendrijft. Daarnaast stuit de elitaire liberale staat met zijn politieke en educatieve eenheidsideaal op heftig verzet van antirevolutionairen, katholieken en socialisten, die als drie nieuwe partijen een tijdperk van pluralisering van de politiek inluiden en daarmee tevens een stevig tegenwicht vormen tegen de overheersing van de liberalen.

Het is de strijd voor de rechtsgelijkheid van de eigen, bijzondere school 
die de historische kloof tussen protestanten en katholieken dempt en hen aanzet tot een hecht antiliberaal samenwerkingsverbond. De Rooms-Dortse coalitie is geboren. Het bijzonder onderwijs heeft door toedoen van het IIberale kabinet-Kappeyne elf strenge winters te verduren eer voor de eigen school in 1889 - tijdens het eerste confessionele coalitiekabinet, onder leiding van de antirevolutionair Mackay - de late lente aanbreekt en na een lang schraal voorjaar, in 1920 eindelijk de zomer inzet. Dan is inmiddels de katholiek Ruys premier van het vierde coalitiekabinet, en begint een tijdperk waarin de zogenoemde rechterzijde langdurig in de meerderheid is.

Met zevenmijlslaarzen zijn we van 1848 beland in 1920. Maar deze haast verschaft onvoldoende inzicht in de ingewikkelde werkelijkheid van het ontstaan van de liberale staat, de rechtse coalitie èn de kabinetten-Ruys de Beerenbrouck.

Met rasse schreden keren we dan ook terug naar het revolutiejaar 1848.

\subsection{De liberale staatsinrichting}

Onder de indruk van de huiveringwekkende berichten over de loop van de omwentelingen in het buitenland - zo is in Frankrijk de monarchie in enkele dagen verdrongen door een democratische republiek - verschiet koning Willem II van politleke kleur. Voortaan conservatief met een liberaal tintje besluit hlj op 17 maart 1848 - overigens buiten zijn ministers om en zonder de gevoelens van de Tweede Kamer af te wachten - tot instelling van een commissie die de grondwet in liberale zin moet herzien.

Onder voortvarende leiding van wetenschapper-politicus Johan Rudolf Thorbecke (1798-1872) gaat de grondwetscommissle, die geheel uit liberalen bestaat, aan het werk en reeds op 11 april biedt zij de koning haar ontwerp aan.

De herzleningsvoorstellen van de grondwetscommissie dragen het nadrukkelijke stempel van Thorbecke. Verrassend is het dan ook niet dat diens liberale gedachtegoed bepaald geen gemeengoed is bij de conservatleve geesten binnen het ministerie-Schimmelpenninck en de Tweede Kamer. Maar de koning geeft geen krimp en vastberaden biedt hij de Staten-Generaal bij koninklijke boodschap van 19 junl de ontwerpen van de commissle-Thorbecke aan.

De Tweede Kamer dwingt enige belangrijke wijzigingen' af alvorens de herzleningsvoorstellen te aanvaarden, en vervolgens kan de Eerste Kamer er zich eveneens mee verenigen. En als de voorstellen ook in tweede lezing de daarvoor vereiste drievierde meerderheid halen, kunnen die op $\mathbb{} 4$ 
oktober 1848 worden bekrachtigd.

\section{* De grondwet van 1848}

De liberale grondwet van 1848 legt de basis voor een geheel nleuw bestel. "De grondwet sloot volkskracht buiten; zij moet die nu in alle aderen des Staats trachten op te nemen ... De burgerij had tot hiertoe het besef, dat zij mederegeerde, niet ... Dat besef wordt door een echte, eenvoudige vertegenwoordiging in plaatselijke, provinciale en landsregering aan de ingezetenen geschonken.", zo vat Thorbeckes memorie bij het ontwerp de vernieuwing van 1848 in haar kern. ${ }^{2}$

De constitutionele inkadering van de monarchale macht, de invoering van de koninklijke onschendbaarheid met de politieke ministeriële verantwoordelijkheid als complement, en de uitbreiding van de rechten van de Staten-Generaal vormen de aanzet tot een meer democratische bestuursvorm, die ooit uitgroeit tot het huidige parlementaire stelsel.

Met rechtstreekse verkiezingen voor de Tweede Kamer, Provinciale Staten en gemeentebesturen heeft de "volkskracht" voortaan stem in het kapittel, mits dit volk de kracht bezit om over de fiscale kiesdrempel te stappen.

Voorts geeft de erkenning van de rechten van vereniging en vergadering en van schriftelijk verkeer uitbreiding aan de individuele vrijheidsrechten van de burgers. Daarnaast brengt de afschaffing van het recht van placet met zich mee dat de kerkgenootschappen hun eigen organisatie in het vervolg zonder bemoeiing van de staat, in vrijheld kunnen regelen. Ten slotte bevat de nleuwe grondwet wijzigingen van het hoofdstuk betreffende het onderwijs. Die krijgen hierna in het onderdeel 1.4 uitgebreid aandacht.

\section{* Monumentaal startpunt}

Zo leidt de roep om hervorming van de "stembevoegde burgerl|" na een goed halfjaar tot een liberaal-elitaire bestuursvorm. De verkiezing van 1849 luidt de opmars van de liberalen en de terugtocht van de conserva. tieven in. De liberale staat is gevestigd, al blijven de conservatleven nog een tijdlang aan de rem trekken.

Er is reden te over om de grondwet van 1848 te beschouwen als een monumentaal startpunt van een nleuwe politieke orde, maar een symblotisch maaksel dat voor nu en later de harmonie in de samenleving verzekert, is zij zeker niet. Het primaat van de openbare school en het exclusieve kiesrecht zijn niet de kleinste gebreken die het werkstuk aankleven. En los dáárvan: het is niet zó dat alleen de grondwet de staatkundige werkelijk- 
heid bepaalt, maar er ziln daarnaast ook ongeschreven regels van staatsrecht dile onderdeel vormen van ons rechtsbestell. ${ }^{3}$

Nu eens door de letter van de eigen wet, dan weer door de tijdgeest ${ }^{4}$ beperkt, is de staatsregeling van 1848 niet bij machte om de nagalm van het ancien régime ineens te stillen, oude strijdvragen definitief te beslechten en op de brandende kwesties van straks adequaat te reageren.

Op deze beperkingen gaan we hierna in de onderdelen $1.3 \mathrm{t} / \mathrm{m} 1.5$ nader in.

\subsection{Nagalm van het ancien régime}

In de jaren 1866-1868 rijst tot tweemaal toe een ernstig conflict tussen de regering en de Tweede Kamer, met als inzet: "... de onderlinge verhouding der onderscheidene Staatsmachten, zoals die door de Grondwet begrensd is ..." 5

Het eerste conflict - de zogenaamde kwestie-Mijer - ontstaat als het conservatieve kabinet-Van Zuylen van Nijevelt-Heemskerk weigert verantwoording af te leggen over de benoeming van de even tevoren afgetreden minister van koloniën Mijer tot gouverneur-generaal van Nederlands-Indië. Benoeming en ontslag van ministers en gouverneurs-generaal, zo verdedigt het kabinet $z \mid j n$ weigering, zljin een prerogatief van de koning, waarvoor de kamer ministers niet ter verantwoording kan roepen. De kamer neemt vervolgens een motie aan waarin zij haar afkeuring over de houding van het kabinet uitspreekt.

De mede-ondertekening door Nederland van een verdrag dat de neutraliteit van Luxemburg garandeert, is de aanleiding tot het tweede conflict de zogenaamde Luxemburgse kwestie. De kamer mist het vertrouwen in het beleid van de minister van buitenlandse zaken Van Zuylen en stemt zijn begroting af.

In een perlode van vijftien maanden leiden deze conflicten telkens tot ontbinding van de Tweede Kamer, nleuwe verklezingen en ... aanblijven van het kabinet.

De uitslag van de laatste verkiezing versterkt de positie van de liberalen. Wederom loopt de spanning hoog op als de nieuwe kamer de jongste ontbinding afkeurt en vervolgens - ten tweeden male - de begroting van buitenlandse zaken verwerpt. Even dreigt het opnieuw op een kamerontbinding uit te draalen, maar na een krachtig protest van binnen en buiten het parlement komt het ditmaal niet zover. Net als bij het ontstaan van het tweede conflict bleden de ministers Willem III hun ontslag aan, en deze keer weigert hij het hun niet. 
Het parlement heeft gezegevierd, de nagalm van het ancien régime is vervlogen. Wat het in 1848 aanvaarde grondwettelijke bestel betekent voor de verhouding tussen regering en parlement is in de jaren 1866-1868 nader verduidelijkt. Sindsdien geldt in ons land de - ongeschreven - regel van staatsrecht dat geen minister kan aanblijven als deze nlet het vertrouwen van de volksvertegenwoordiging blijkt te hebben, in welke regel ligt opgesloten dat gebruikmaking van het recht van ontbinding van de kamer(s), slechts éénmaal ter zake van hetzelfde conflict is toegestaan. ${ }^{6}$

\subsection{Fundamentele strijdvragen}

Het heeft in de negentiende eeuw niet ontbroken aan fundamentele strijdvragen. Mijlenver lopen de meningen uiteen over de thema's onderwijs en kiesrecht. Fel en onverzettelijk woedt de strijd in de politleke arena totdat hier in 1917 eindelijk de vredesduif neerstrijkt.

\section{* De onderwijskwestie}

In de lijn van de destijds heersende opvatting dat onderwijs een algemeen belang en dus een taak van de staat is, vestigt de schoolwet van 1806 het monopolie van de openbare school. De wet kent ook de bijzondere school, maar deze sectarische pendant mag niet worden opgericht dan alleen met vergunning van het - vaak onwillige - gemeentebestuur. De tijdgeest van toen geeft de openbare school het karakter van de enige echte nationale school, die dienstbaar als zil is aan de eenheid van de natle en de vereniging van alle gezindten, moet opleiden tot alle maatschappelijke en christelijke deugden.

Onder de werking van de wet van 1806 is er beslist geen sprake van viijheid van onderwijs. Gaandeweg ontstaat aan orthodox-protestantse en katholieke kant verzet tegen het neutrale karakter van de nationale school en het autorisatievereiste waaraan de bijzondere school is gekluisterd.

De grondwetsherziening van 1848 introduceert het beginsel van vr|jheid van onderwijs. "De inrichting van het publiek onderwijs wordt, met eerblediging van leders godsdienstige begrippen, door de wet geregeld. Het geven van onderwijs is vrij, behoudens het onderzoek naar de bekwaamheid der onderwijzers en het toezicht der overheid, beide door de wet te regelen.", luidt het voorstel van de commissie-Thorbecke. Deze aantasting van het primaat van de nationale school ondervindt echter sterke tegenkanting. Onder de druk van invloedrijke vrijzinnige kringen en zelfs van modernistische kerkelijke zijde ontkomt de regering er niet aan enige be- 
langrilke accentverschuivingen - "Het openbaar onderwijs is een voorwerp van de aanhoudende zorg der Regering ... Er wordt overal in het Rijk van overheldswege voldoend openbaar lager onderwijs gegeven." - in de definitieve tekst aan te brengen.

De nleuwe wet op het lager onderwils van 1857 breekt met het autorisatlevereiste en handhaft het neutrale karakter van de openbare school. Dit laatste is de antirevolutionair Groen van Prinsterer een gruwel. Vergeefs liverde hil voor een schoolwet die het hele onderwijs zou splitsen naar kerkelijke gezindten. Zonder succes bleef ook zijn poging de katholieken voor dit standpunt te winnen: na driehonderd jaar schullkerk en met een verse herinnering aan de protestantse furle van 1853 tegen de vrije verhoudingen op kerkelijk gebied, hebben "de roomse inboorlingen onder de grote rivleren" - een benaming waarmee Groen eertijds uitdrukte welke achting hil voor hen voelde - nog steeds alle belang bij een hechte band met de liberalen, en moeten van een calvinistische toenadering nog even niets weten ...

Teleurgesteld keert de grondlegger van de antirevolutionaire staatsleer zich met ziln geestverwanten af van de openbare school. Weldra gaat de school met de Bijbel zich verbreiden.

In de jaren zestig begint ook bij de katholieken de onderwijskwestie een belangrijke rol te spelen. In het spoor van de pauselijke encycliek Quanta Cura van 1864 noemt het mandement van de Nederlandse bisschoppen de neutrale staatsschool een product van verderfelijke liberale opvattingen, en derhalve ongeschikt en uiterst gevaarlijk voor de katholieke jeugd: "De Kerk will, dat de jeugd in wetenschappen onderwezen worde, maar zij eist tevens dat dit onderwils in alle opzichten Katholiek en godsdienstig zlj.", heet het in het herderlijke schrijven van 1868.

Als twee jaar later de liberaal-nationalistische beweging in litaliö de pollneke en territorlale eenmalking van dit land voltooit en daarmee tevens een eind maakt aan de wereldllke macht van de paus, is deze gebeurtenis voor de Nederlandse katholieken aanleiding om voorgoed te breken met de lberale bondgenoot, die overloopt van enthousiasme voor ginds Risorgiñento.

\section{* Het kiesrechtvraagstuk}

Naast het onderwijs is ook het kjesrecht een telkens terugkerend onderwerp op de politieke agenda. Kiesrecht heeft alleen hij die ten minste een door de wet bepaald minimumbedrag in de directe belastingen betaalt. Deze censuseis, waaraan slechts zo'n $10 \%$ van de volwassen mannelijke 
bevolking voldoet, maakt van het kiesrecht een privilege van een elite en laat vrijwel geen ruimte voor uitbreiding van het kiezerskorps.

Minstens zo ongelukkig is de regeling van het kiesstelsel, die bil groel van het aantall leden van de Tweede Kamer telkens uitbreiding en herindeling van kjesdistricten nodig maakt, wat resulteert in een lappendeken van enkel- en meervoudige districten van ongelijk stemgewicht. ${ }^{7}$

\section{* Kappeyne speelt met vuur}

Na 1870 ontstaat er een krachtige beweging die herziening van de wetgeving op het gebied van onderwijs en kjesrecht wil. Onder het liberale kablnet-Kappeyne van de Coppello (1877-1879) stijgen beide kwesties tot het kookpunt.

In alle hevigheid ontbrandt de schoolstrijd als het kabinet-Kappeyne de herzlening van de schoolwet aanpakt. Reeds lang wordt er van alle kanten aangedrongen op wijziging van de wet van 1857 . En daarbil staat de liberalen verbetering van het openbare onderwijs voor ogen, terwijl het de beide confessionele stromingen speciaal te doen is om subsidiëring van de bijzondere school, die tot dusver alleen op particuliere middelen is aangewezen.

Bij de wet van 1878 worden de eisen waaraan openbare én bijzondere scholen moeten voldoen, sterk opgevoerd. De gemeenten, die daardoor voor hogere lasten komen te staan, kunnen voortaan een ruime rijkssubsidie tegemoet zien, maar "Inrichtingen die bedoelen te verdelen hetgeen de wet begeert verenigd te houden, hebben op begunstiging geen recht.", schrijft Kappeyne, met een beroep op de grondwet, in de memorie van toelichting. ${ }^{8}$ Het gevolg is dat de bijzondere scholen voor nóg hogere lasten komen te staan.

Fel keert Kuyper, de nieuwe voorman van de antirevolutionairen, zich in zljn partijkrant De Standaard tegen "de scherpe resolutie" dle de vrlje school "zó ruw en zó hardhandig" behandelt. " Heftig bestrijdt ook de katholieke prominent Schaepman "het decretum horribile" in het dagblad De Tijd. ${ }^{10}$ Via volkspetitionnementen verzoeken ruim 450.000 protestantse en katholieke burgers de koning de knevelwet niet te tekenen. Zij hebben echter geen succes, want Willem III is inmiddels vertrouwd met het in 1848 aanvaarde bestel ...

Met zijn rigide schoolwet bewijst Kappeyne het bijzonder onderwijs èn ... zijn eigen liberale partil een slechte dienst: door zijn radicale houding in de schoolkwestie wordt hij de ongewilde smid van een hecht, antiliberaal samenwerkingsverband van calvinisten - in 1879 door toedoen van Kuyper verenigd in "s lands eerste politieke parti], de Antirevolutionaire Partl]. - 
en katholieken, die thans schouder aan schouder de bestrijding van de discriminatie van de elgen school tot hun politieke hoofdthema verheffen.

Ook in de kjesrechtkwestie zoekt Kappeyne de moeilijkheden op. In de liberale gelederen staan de voor- en tegenstanders van kiesrechthervorming lijnrecht tegenover elkaar. Vooral onder de jongere liberalen wint de mening terrein dat het kjesrecht niet uitsluitend aan census gekoppeld mag blijven. Voor hen is de grondwet derhalve aan revisie toe.

Kappeyne hoort ook in het progressieve kamp, maar omwille van de lieve vrede in zijn kabinet en partij houdt hij het heikele item van het kiesrecht bulten het regeerprogram. Medio 1879 grijpt hij echter zijn kans om daarop terug te komen: in de verwerping van de kanalenwet door de Tweede Kamer zien de verantwoordelijke minister van waterstaat Tak van Poortvliet, die eveneens een verklaard voorstander van kiesrechthervorming is, en Kappeyne aanleiding om hun ontslag in te dienen. Als de koning dit voorshands weigert, is Kappeyne bereid op zijn post te blijven, onder de voorwaarde dat hem wordt toegestaan een grondwetsherziening die uitbreiding van het klesrecht mogelijk maakt, in gang te zetten. Het kabinet is evenwel nog steeds onverminderd verdeeld over Kappeynes denkbeeld, waarop de beide ministers alsnog hun ontslag krilgen en de dolende romp van het kabinet vervolgens ook snel opstapt.

Het stemrechtvraagstuk is in deze hectische kabinetsperiode geen stap nader tot een oplossing gekomen, zit nu zelfs muurvast, maar over enige jaren blijkt dat Tak de moed nog niet heeft opgegeven.

\section{* De grondwetsherzlening van 1887}

Het conservatieve kabinet- J. Heemskerk (1883-1888) geeft bij zijn aantreden te kennen een algehele herzlening van de grondwet te willen nastreven. Ook de breed gewenste hervorming van het kiesrecht zal in die herzlening worden meegenomen.

Het kabinet krljgt het zwaar te verduren zodra het parlement de herzieningsontwerpen onder ogen krijgt. Met geen woord reppen die over de schoolkwestie, reden waarom de rechterzijde verklaart niet te kunnen ("non possumus") meewerken aan de herziening als het onderwijsartikel ("194") niet in hun geest wordt gewijzigd. Ook de kiesrechtvoorstellen krilgen fors weerwerk: waarom geen blanco artikel dat de gewone wetgever de vrije hand laat; waarom naast Individueel kiesrecht geen organische varlant, waardoor ook de stem van de maatschappelijke verbanden kan doorklinken ?, kritiseert men Heemskerk van diverse zijden.

De herzlening dreigt zó op dood spoor te raken, en het kabinet bledt zijn 
ontslag aan. Als er echter geen politiek alternatief blijkt te zijn, keert het kabinet terug en wordt de Tweede Kamer ontbonden. Na de verkiezing worden de voorstellen opnieuw bij de Staten-Generaal ingediend. Met de voorstemmen van de liberalen aanvaardt de nieuwe kamer thans de regeringsvoorstellen, met inbegrip van het ontwerp dat kiesrecht toekent aan de "mannelijke ingezetenen, tevens Nederlanders, die de door de kieswet te bepalen kentekenen van geschiktheid en maatschappelijke welstand bezitten."

Bredere instemming van de kamer krijgt bovendien een initlatiefvoorstel van Schaepman tot herziening van het onderwijsartikel 194. Maar dit voorstel strandt in de Eerste Kamer, waarbij de liberale tegenstemmers overigens onthullen dat artikel 194 het subsidiëren van de bijzondere school niet verbiedt... In de war door deze verbluffende tekstverklaring geeft een aantal rechtse vertegenwoordigers in tweede lezing ook zijn steun aan alle regeringsontwerpen.

De grondwetsherziening van 1887 is een feit.

\section{* Het eerste rechtse coalitiekabinet}

Rechts krijgt hij de verkiezing van 1888 voor het eerst een meerderheid. De antirevolutionair baron Mackay wordt premier van het - eerste - coalltiekabinet van AR en RK (1888-1891). Zijn regeerprogram omvat onder meer de invoering van een arbeidswet en - vanzelfsprekend - een herziening van de schoolwet.

De herziene schoolwet van 1889 is een eerste stap in de richting van gelijke behandeling van openbaar en bijzonder onderwijs: zij kent namelijk het bijzonder lager onderwijs eenzelfde rijkssubsidie toe als de openbare school reeds sinds 1878 ontvangt.

\section{* Takkianen versus anti-Takkianen}

In 1891 wordt Tak van Poortvliet weer minister. Als bewindsman van binnenlandse zaken stelt hij zich tot doel uitvoering te geven aan het kiesrechtartikel van de grondwet.

Een jaar later presenteert hij de vrucht van zijn legislatieve arbeid: klesrecht voor leder die kan lezen en schrijven en in staat is, zonder bijstand van de armenzorg, in eigen onderhoud te voorzien. Het is een ontwerp als een splijtmes, dat de meeste kamerfracties verdeelt in progressieve en conservatieve vleugels, in fervente Taldkianen en anti-Takkianen.

Dit wetsvoorstel is strijdig met de grondwet, is een "legislatief wangedrocht", dat met uitzondering van analfabeten en bedeelden, aan leder- 
een kiesrecht geeft; betogen de anti's rond de liberaal Van Houten en de antirevolutionair De Savornin Lohman.

Bil de katholieken staat Takkiaan Schaepman vrijwel alleen tegenover een kamerclub die in het partijblad De Maasbode haar bedenkelijke spreekbuis heeft: "De ondervinding bewijst, dat het [geven van stemrecht aan mensen die totaal geen inzicht in de politiek hebben] slechts revolutie en anarchie voortbrengt." "I

Tak stuit dan ook op hevig verzet in de Tweede Kamer, en als deze een hem onwelgevallig amendement aanneemt, wordt de kamer ontbonden en het geschil voorgelegd aan de (census-)kiezers.

De kamerverkiezing geeft de anti-Takkianen een ruime meerderheld. Na de kabinetswisseling van 1894 komt de gematigde liberaal Van Houten op binnenlandse zaken. In 1896 brengt hij zijn kieswet tot stand, die census als maatstaf handhaaft, maar ook woning-, loon-, spaar- en examenkiezers toelaat. Het aantal kiesgerechtigden verdubbelt daardoor en groeit uit tot 600.000 .

\section{* Politieke hergroepering}

De strijd om het kiesrecht heeft in de jaren negentig ingrijpende gevolgen voor de politieke verhoudingen. De kieswet-Van Houten gaat de behoudende te ver, de radicaal niet ver genoeg en is de gematigde voorlopig voldoende. Met de eenheid onder de liberalen, de antirevolutionairen en de socialisten is het afgelopen.

Sinds 1885 zijn de liberalen verenigd in de Liberale Unie. Deze zit op de lijn van Tak, wil het kjesrecht zo ver mogelijk oprekken, maar kan voorlopig wel leven met Van Houtens wet. Zo niet de linkervleugel van de Unie. Die staat pal voor algemeen mannen- en vrouwenkiesrecht, vindt daar in de moederpartif onvoldoende gehoor voor en sticht in 1892 de Radicale Bond, die zich in 1901 aansluit bij de Vrijzinnig-Democratische Bond. Ook de anti-Talkkiaanse rechtervleugel keert zich van de Unie af, vaart vanaf 1894 zijn eigen koers onder de vlag van oud-liberalen, en gaat in 1906 op in de Bond van Vrije Liberalen.

Een dergelijke driedeling doet zich ook voor in de protestantse gelederen. Door gevoelige kwesties als kiesrecht en kerkelijke tegenstellingen treedt een verwijdering op tussen de aanhangers van Kuyper en Lohman. Het komt tot een officiële splitsing als de groep-Lohman zich in 1898 als VrijAntirevolutionaire of Christelijk-Historische Partij afzonderlijk gaat organiseren. Intussen heeft zich in 1896 nóg een partij op christelijk-historische 
grondslag gevormd, de Christelijk-Historische Kiezersbond van De Visser, die in 1908 met de partij van Lohman en de Friese Christelijk-Historische Kiesvereenigingen samensmelt tot de Christelijk-Historische Unle, de $\mathrm{CHU}^{12}$

Bij de socialisten openbaart zich eveneens verdeeldheid. In de Sociaal-Democratische Bond van 1882 is een felle strijd ontbrand tussen de parlementaire en antiparlementaire richting. De laatste richting, waartoe Domela Nieuwenhuis behoort, heeft haar bekomst van het parlementaire werk en wil haar socialistische ideaal via directe, buitenparlementaire actie verwezenlijken. Als de Bond zich uitspreekt voor de antiparlementaire, anarchistische koers, richten Troelstra en elf volgelingen - De Twaalf Apostelen - in 1894 een nieuwe marxistische partij op, die haar program wèl langs parlementaire weg beoogt te verwezenlijken: de Sociaal-Democratische Arbeiderspartij, de SDAP, een sterk voorstander van algemeen kiesrecht voor mannen en vrouwen.

De katholieken zijn de enige groepering die intact blijft. "Eén tegen Tak", is het parool dat nagenoeg alom in hun kring opgeld doet. In deze negatieve lading blijkt nu juist het bindmiddel te zitten waarnaar hun staatkundige leider - en Takkiaan - Schaepman vanaf 1883 op zoek is. In dat jaar publiceert hij in Onze Wachter zijn fundamentele artikel: "Een Katholieke Partij. Proeve van een program", waarin hij de katholieken het sein geeft - net ais Kuypers "Ons Program" dat eerder aan de protestanten deed - dat zil zich moeten verzamelen in een eigen politieke partij. ${ }^{13}$

Tóen haalden de meeste geloofsgenoten hun schouders op voor het Idee van die jeugdige nieuwlichter, uit Tubbergen nog wel I Nú heeft Schaepmans appèl wèl succes: in 1896 lukt het hem alle katholieke Tweede-Kamerleden, in 1897 ook alle bestaande kiesverenigingen, onder één program en leiding te scharen. De Rooms-Katholieke Staatspartl], de RKSP, is present.

\section{* Het "slavenjuk" van de leerplicht}

Nogmaals komt de schrille tegenstelling van openbare en bijzondere school naar buiten tijdens het liberale kabinet-Pierson-Goeman Borgesius (1897-1901). In het kader van het omvangrijke regeerprogram op het gebied van sociale wetgeving ontwerpt Borgesius een regeling in het belang van scholing en maatschappelijke opvang van het kind: de leerplicht.

Het ontwerp ontketent een stormloop van rechts. De staat wil zich van onze kinderen meester maken en dwingt ouders hun kinderen naar de 
openbare school te sturen als de school van hun voorkeur ontbreekt, zo klinkt het luide protest van confessionele zijde.

Töch wordt leerplicht in 1900 wet, al springt Borgesius in de Tweede Kamer met de hakken over de sloot: 49 van de 100 afgevaardigden stemmen tegen, onder wie alle socialisten - zij missen in de leerplichtwet de sociale component -, alle leden van de protestants-christelijke fracties en ... bijna alle katholieken.

"Eén mens heeft aan honderdduizenden landgenoten het gevloekte slavenjuk van de leerplicht op de nek getast. En vraagt gij, wie die éne mens is, dan moeten wij $u$ helaas antwoorden: dat is dr. Schaepman. Diepbedroevend voorwaar.", venijnt de Limburger Koerier ${ }^{14}$, en vergeet in zijn haastige spoed dat óók Kolkman een uitzondering op de conservatieve regel is.

\section{* Antithesepolltiek van Kuyper}

In deze opgewonden sfeer komt na de verkjezing van 1901 rechts weer aan de regering. De vrijmaking van het onderwijs in al zijn geledingen staat hoog in het vaandel van het tweede coalitiekabinet van AR en RKSP, onder leiding van Kuyper (1901-1905).

"Niet aan deze of gene groep de voorrang toekennen, niet de eenheid der natie prijsgeven, geen bevoorrechting of miskenning, doch aan de beide antithetische delen eenzelfde kans laten." ${ }^{15}$, zo accentueert de nieuwe premier de tegenstelling christendom-paganisme.

De hogeronderwijswet wordt herzien en verleent aan de bijzondere gymnasia en bijzondere universiteiten - op dit moment nog geen andere dan Kuypers eigen Vrije Universiteit - effectus civilis en subsidie. Dit gaat echter niet zonder slag of stoot. In eerste instanile verwerpt de Eerste Kamer, waar de liberalen de boventoon voeren, het wetsvoorstel, dan forceert Kuyper de ontbinding van de Senaat, waarna de nieuwe - volgens de voorcalculatie in meerderheid rechtse - kamer het voorstel wel aanvaardt.

$\mathrm{Nu}$ is er ook geen parlementair obstakel meer dat forse verhoging van de rijkssubsidie voor alle lagere scholen en opneming van alle onderwijzers in de rijkspensioenregeling in de weg staat.

Het is een rijke oogst die Kuyper voor het bijzonder onderwijs binnenhaalt, maar de nadruk die hij daarbij op de antithese legt en het machtsvertoon waarvan hij zich bedient bij de ontbinding van de Eerste Kamer en bij de spoorwegstakingen van $1903^{16}$, zetten de staatkundige verhoudingen onder hoogspanning. De pacificatie waar menigeen allengs naar smacht, is zeker niet van hém te verwachten. 
Onder het kabinet-Th. Heemskerk (1908-1913) - wederom een coalitie van AR en RKSP - krijgen de bijzondere Hogere Burgerscholen recht op subsidie. Het kabinet komt in februari 1913 met voorstellen tot herziening van de onderwijs- en kiesrechtbepalingen in de grondwet. Het onderwijsvoorstel gaat uit van financiële gelijkstelling van openbaar en bijzonder lager onderwijs en wil van de vrije school regel, van de openbare school uitzondering maken. Op het punt van het kiesrecht is het voorstel om het in de AR aangehangen huismanskiesrecht in de grondwet vast te leggen.

De tijd is evenwel spelbreekster. De voorstellen komen niet meer aan de orde vóór de verkiezing van zomer 1913, maar zijn wel de inzet van een hevige stembusstrijd.

Als vrijzinnige concentratie gaan de drie liberale partijen de verklezing in. Voor dit moment zijn de drie één in hun brandende zorg over de ondermijnende werking van de antithesepolitiek van rechts op hun liberale beginselen en hun nationale eenheidsideaal. Tegenover het organische kiesrecht en de vrije-school-als-regel van Heemskerk c.s., plaatst het liberale verkiezingsmanifest het algemeen mannenkiesrecht en de versterking van de positie en de kwalliteit van de nationale, openbare school.

Daarnaast zijn ook het staatspensioen en de wettelijke-regeling-metstaatssteun van ziekenfondsen en ziektekassen programmapunten die sluitende stembusafspraken met de SDAP mogelijk maken. De aldus ontstane linkse concentratie wint met 55 tegen 45 zetels de verkiezing.

\section{* Pacificator tussen rechts en links}

Een vrijzinnig-rood kabinet daagt aan de horizon als koningin Wilhelmina, na consultatie van de leiders van de linkse concentratie - óók Troelstra maakt zijn opwachting op Het Loo -, de vijzinnig-democraat dr. D. Bos opdracht geeft een kabinet "uit de gehele linkerzijde" te vormen. De SDAP is echter niet happig op regeringsverantwoordelijkheid, blijft maar talmen en schuift zó een eerste paars kabinet 81 jaar voor zich uit ...

Het liberale minderheidskabinet-Cort van der Linden (1913-1918) dat na de vergeefse formatiepoging van Bos aantreedt, maakt algemeen kiesrecht voor mannen en staatspensioen tot de hoofdpunten van zijn regeerprogram. Voor de grondwetsherziening op het stuk van het kiesrecht is ook de medewerking van de rechterzijde nodig, realiseert Cort van der Linden zich. Wil hij in zijn opzet slagen, dan moet hij al zijn wijsheid en tact inzetten om de hevige stammenstrijd te matigen. 
De troonrede van 1913 kondigt de instelling van een staatscommissie aan die zal onderzoeken "in hoever een algemeen bevredigende regeling mogelijk is ter zake van de subsidiëring van het bijzonder onderwijs en de voorwaarden, welke daaraan verbonden moeten worden." 17 Een tweetal staatscommissies gaat aan het werk.

Het rapport van de commissie- "klesrecht" is nog vóór het begin van de wereldoorlog klaar, en op basis daarvan dient de regering in oktober 1915 twee ontwerpen bij de Tweede Kamer in. Deze beogen algemeen kiesrecht voor mannen, onmiddellijke verkiesbaarheid van vrouwen, evenredige vertegenwoordiging voor de Tweede Kamer, Provinciale Staten en gemeenteraden, èn invoering van stemplicht. In het voorlopige verslag komt rechts met een reeks van bezwaren tegen algemeen kiesrecht, tot op 11 maart $1916 \ldots$ het verslag van de commissie-"onderwijs" verschijnt.

Deze commissie, bestaande uit veertien Tweede-Kamerleden - van elk van de zeven fracties de leider en een onderwijsspecialist - onder voorzitterschap van de welbekende gewezen kabinetsformateur Bos, is het met de grootst mogelijke meerderheid eens geworden over de redactie van een nleuw artikel 192. Het kabinet neemt het voorstel, dat uitgaat van financiele gelijkstelling van het bijzonder met het openbaar onderwijs, over en dient het bij de Tweede Kamer in.

De klesrecht- en onderwijsontwerpen komen te zamen in openbare beraadslaging. $\mathrm{Blj}$ amendement wordt nog wat gesleuteld aan de positie van de openbare school (“... In elke gemeente ... voldoend openbaar algemeen vormend lager onderwijs... Volgens bij de wet te stellen regels kan afwijking ... worden toegelaten, mits tot het ontvangen van zodanig onderwijs gelegenheid wordt gegeven ..."), alsmede aan de waarborging van de deugdelijkheid van het onderwijs op de bijzondere school (“... de deugdelijkheid van het geheel uit de openbare kas bekostigd bijzonder onderwijs en van het openbaar onderwijs [wordt] even afdoende gewaarborgd ... met inachtneming, voor zover het bijzonder onderwijs betreft. van de vrijheid van richting ..."). Maar dàn gaan de voorstellen er in de Tweede en Eerste Kamer ook vlot door.

Onmiddellijk daarna volgt de grondwettelijk voorgeschreven ontbinding van de kamers. De nieuwe kamers - waarin krachtens akkoord tussen de partijen: "laat zitten wat zit", alle aftredende leden zijn teruggekeerd - behandelen de voorstellen in tweede lezing met hetzelfde resultaat, waarna de bekrachtiging volgt op 19 november 1917.

Na zo'n halve eeuw van strijd is de pacificatie voltooid. Dit is de historlsche verdienste van Cort van der Linden, die zich met recht een "eerlijk makelaar tussen rechts en links" mag noemen.

In juli 1918 moet stemgerechtigd Nederland weer naar de stembus. Voor 
het eerst zijn de nieuwe kjesrechtbepalingen van toepassing op de verkiezing van de Tweede Kamer. Een nleuw tijdperk in onze parlementaire geschiedenis is aangebroken.

\subsection{Van staatsonthouding tot staatsinterventie}

Zoals in het begin van dit hoofdstuk is aangegeven, doet in 1848 een verlicht liberalisme zijn intree in de politiek. Het politieke bedrijf wordt daarmee het privilege van een elite, d.w.z. van een met rede en/of have begaafde bovenlaag van de burgerij.

Volgens de klassiek-liberale doctrine zijn het juist deze burgers die met volle vrijheid van handelen in staat worden geacht de economische, sociale en culturele processen te beheersen en voor maatschappelijk evenwicht te zorgen. In deze gedachtegang mag de staat zich niet met het zelf-organiserende vermogen van de individuen bemoeien, want dit zou het maatschappelijke evenwicht alleen maar verstoren ...

Afgezien van de aanhoudende overheidszorg voor het vrijzinnige paradepaard van de nationale school, start in de liberale bedding van 1848 een tijdperk van staatsonthouding op sociaal en economisch terrein. De enorm snel groeiende inclustrialisatie in de tweede helft van de negentiende eeuw veroorzaakt een totale wijziging van de arbeidsverhoudingen. Van het kleinschalige "huur van dienstboden en werklieden", waarvoor het Burgerlijk Wetboek van 1838 een drietal bepalingen bevatte, wordt arbeid een massaverschijnsel dat om maatregelen vraagt die het privaatrecht overstijgen.

De volledige staatsonthouding op het gebied van de arbeid heeft het ontstaan van ernstige misstanden sterk in de hand gewerkt. Sociale wetgeving past niet in het liberalisme van Thorbecke, ligt dus buiten de scope van zijh grondwet. Als het liberale kamerlid Van Houten in 1871 aandringt op wettelijke maatregelen ter bestrijding van de uitwassen van de kinderarbeid, krijgt hij van Thorbecke te horen: "Wanneer een lid der Kamer aandringt op wettelijke regeling van enig onderwerp en zegt, dat hij alle gevolgen daarvan heeft berekend, dan is zijn taak eer zelf het initiatief te nemen dan een minister, die nog aarzelt, tot het nemen van het initiatief aan te moedigen." ${ }^{18}$ Kennelijk gaat de sociale kwestie de regering nog steeds niet aan, en zo neemt Van Houten het voortouw en bewerkstelligt hij met zijn wet van 1874 het verbod van arbeild door kinderen beneden twaalf jaar. 
De kinderwet-Van Houten is de voorloopster van staatsinterventie die ondanks de tegendruk van de liberale staatsidee, maar ook van de onder de antirevolutionairen en katholieken heersende vrees voor vergaande staatsinvloed - steeds dieper gaat doordringen in het maatschappelijke leven.

De omslag van de klassieke staatsonthouding naar een democratische en sociale staatsbemoeiing voltrekt zich niet van de ene dag op de andere, maar is een moeizaam proces van lange adem, met veel horten en stoten. Bijzonder onderwijs en leerplicht zijn reeds gememoreerde voorbeelden van een weinig toeschietelijk zorgbesef van de politiek. Ook in de discussies tijdens het coalitiekabinet-Mackay over het ontwerp-arbeidswet van minister van justitie Ruys de Beerenbrouck senior en de invoering van de persoonlijke militaire dienstplicht (de afschaffing van het zogenaamde remplaçantenstelsel) strijden een meer individueel en algemeen belang om de voorrang.

Eerst onder het liberale kabinet-Pierson-Goeman Borgesius verliest het laissez faire, laissez passer zijn vanzelfsprekendheid. "Laat aan het Nederlandsche volk zien, dat gij de woorden, waartoe ook gij u tot heden grootendeels bepaald hebt, in daden weet om te zetten, en zorgt, dat men van u kunne getuigen niet alleen, dat verwacht werd dat gij zóudt zijn, maar ook, dat gil gewéést ziljt een ministerie van sociale rechtvaardigheid." 19 . houdt het nleuwbakken Venlose kamerlid Nolens Pierson en zijn ministersploeg op 1 december 1897 voor. En het kabinet laat het niet bij woorden, maar realiseert een indrukwekkend program op het gebied van arbeidersbescherming, sociale verzekering, gezondheidszorg, leerplicht en volkshuisvesting.

Talma, minister van landbouw, nijverheid en handel in het derde confessionele coalitiekabinet, onder leiding van Th. Heemskerk, gat in deze ijn verder en bevordert in de jaren tot aan de Eerste Wereldoorlog een forse uitbreiding van de sociale wetgeving. Tijdens de oorlog vragen andere zaken de grootst mogelijke aandacht en ligt de wetgevende arbeid op sociaal terrein vrljwel stil.

Tegen het negentiende-eeuwse liberale beginsel van staatsonthouding in. is de bemoeiling van de overheid met het sociaal-economische leven rond de eeuwwisseling schoorvoetend op gang gekomen. Twee decennia later staat de "liberale nachtwakersstaat" 20 op het punt van aflossing door een bestel dat zich gaandeweg ontwikkelt tot de verzorgingsstaat van de tweede helft van de twintigste eeuw. 


\subsection{Inleiding}

Het heette een Monsterverbond toen calvinistens en katholieken zich amper twintig jaar na de Aprilbeweging van 1853 coaliseerden tegen het IIberale onderwijsfanatisme.

Nu mag een dergelijk verbond niets met vriendschap van doen hebben, Intussen was het wèl een ommekeer in de politieke verhoudingen dat twee elkaar zo weinig toegedane groeperingen hun traditionele tegenstellingen ondergeschikt gingen maken aan het grote doel dat zi] gemeen hadden en hen tot gestadige samenwerking bracht: de rechtsgelijkheid van de bijzondere school.

De toenadering tussen de confessionelen is geen proces dat zonder aarzeling en weerstand verliep. Maar historicus $\mathrm{N}$. de Rooy overdrijft als hi] die eerste stappen tot coalitievorming in In Vrijheid Herboren bestempelt als een louter opportunistische actie van antipoden: "Zonder elkander excuses te maken over het verleden of afspraken te maken voor de toekomst, besluiten de twee colonnes elkaars marsroute nlet te hinderen. Men schonk elkander geen vertrouwen of vriendschap, maar rekende er slechts op, dat wie naar Genève of Rome reizen, een tijd lang op elkaars gezelschap zijn aangewezen. Wat de leiders van deze tocht betreft: Schaepman ter ener, Kuyper en De Savornin Lohman ter anderer zijde; zij hebben met elkaar en hun tochtgenoten veel te stellen gehad." ...'

Eerder dan Kuyper, zien Schaepman en Lohman in de jaren zeventig van de negentiende eeuw de mogelijkheden en kansen van een interconfessionele samenwerking. In ideaal en vriendschap verenigd, trekken de $k a-$ tholieke voorman zonder achterban en de calvinist zonder katholiekenvrees de aanvankelijke antipapist Kuyper de coalitie in. En het is deze krachtige trojka die haar aanhangen mobiliseert en tot tochtgenoten maakt op een zware reis, die hen onder haar leidi7ng langs de mijlpalen van drie coalitiekabinetten naar het einddoel van de onderwijsvrede voert.

\subsection{Rechts coalitieverbond staat op springen}

Het oude coalitieverbond Schaepman-Lohman-Kuyper vertoont in 1918 
wilzen. Ook ziet hil niets in het aanblijven van het kabinet-Cort van der Linden, hoewel de oppositierol hem niet belette goede zaken te doen met de liberale premier - een politieke lat-relatie waarop een argwanende Kuyper onlangs het brandmerk "ontrouw van de Roomsch-Catholieke Chef" drukte ... ${ }^{5}$

Nolens maakt zlch van de aanvang af sterk voor een rechts kabinet, geformeerd door een katholiek. Want dăt past, volgens hem, bij de nieuwe politieke verhoudingen waarin de katholieken recht hebben op een prominente plaats in het landsbestuur.

\subsection{Nolens formateur}

De formatie van 1918 loopt allerminst van een leien dakje. En dat ligt niet aan de liberale en sociaal-democratische fracties, want hun leiders geven te kennen de vorming van een rechts kabinet geen strobreed in de weg te willen leggen.

In de rijen van de coalitie heerst echter opperste verdeeldheid. Eerst worden protestanten en katholieken uit elkaar gedreven door de vraag aan welk soort kabinet zil hun medewerking zouden moeten geven. Later, als onder krachtige impuls van koningin Wilhelmina ${ }^{6}$ een rechts kabinet tot gemeenschappelijk uitgangspunt van de bondgenoten is verheven, zijn dezen het weer oneens over de kerkelijke kleur en de persoon van de nieuwe premier.

$\mathrm{Na}$ enige strubbelige positiebepaling in het rechtse front is het op 13 juli zover dat Nolens de opdracht krijgt een rechts kabinet te vormen. Voor het eerst in de parlementaire geschiedenis staat een katholiek politicus, een priester nog well, voor deze belangrijke taak. Katholiek Nederland reageert vol vreugde en trots op deze historische mijlpaal: "Het kwam U zonder twijfel vóór anderen toe, en ik verheug er mij van ganscher harte over, dat men te bevoegder plaatse zulks heeft ingezien. Maar ook voor de Katholleke partij geeft het reden tot groote blijdschap. Aan de eer der partij is nu volkomen voldaan. We zijn toch vooruitgegaan; slechts 65 jaar na de Aprilbeweging wordt een Priester de Kabinetsformatie opgedragen, en nlemand denkt zelfs aan rustverstoring.", schrijft partijvoorzitter mr. A. baron van Wijnbergen aan Nolens op dit gedenkwaardige moment voor de emancipatie van het katholieke volksdeel. ${ }^{7}$

\section{* Eén vulltje aan de lucht}

Tien dagen na de verkiezing ligt de formatietaak uiteindelijk in handen van 
iemand die bij de aanvaarding van zlijn opdracht liet weten, vanwege zijn geestelijke ambt in geen geval zelf minister te willen worden. En dit laatste maakt van Nolens, die de stelregel aanhangt dat een kabinet eenheid en kracht mist als de formateur daar geen deel van uitmaakt, een opdrachtnemer die niet méér en - hem kennende - vooral niet mínder dan wegbereidervoor een ander wil zijn. ${ }^{8}$

Het beraad van de formateur met de top van de drie rechtse fracties loopt voorspoedig. Over programmatische en portefeuillekwesties is men het binnen enkele weken met elkaar eens. De contouren van een nieuw kablnet tekenen zich af, maar er is nog één vuiltje aan de lucht: de allesoverheersende vraag wie premier moet worden!

Nooit eerder was er bij een kabinetsformatie zo veel te doen om het premierschap. Zeker, de internationale situatie alsook de economische toestand van het land vragen om een sterk en homogeen kabinet, onder probate leiding. Maar er is méér aan de hand. Tijdens de formatie van Nolens bekruipt menig calvinist de vrees voor, aldus Colijn, "de machtsbegeerte der RK Club". 9 Deze verontrusten willen voorkomen dat de formatie de verkeerde kant opgaat, want hebben die roomsen eenmaal het premlerschap, panikeert Kuyper, "dan komen wij als geloovige protestanten daarna nooit meer aan bod". ${ }^{10}$

Nolens toont zich de formateur die de broze verhoudingen binnen de rechtse gelederen met een scherp gevoel voor het haalbare juist inschat. $\mathrm{Hij}$ komt tegemoet aan de dringende behoefte aan profilering bij zijn protestantse partners en onderdrukt daarbi| zi|jn voorliefde voor een katholieke premier.

Pas als voor en na alle eerste-ministeriabele figuren uit de AR en de $\mathrm{CHU}$, als Colijn, Idenburg en Lohman, het om verschillende redenen laten afweten, en de AR haar vroegere premier Heemskerk onwrikbaar als persona non grata voor dat ambt blijft beschouwen - hem treft nog steeds het verwijt, de kans op een tweede kabinet-Kuyper in 1908 ult elgenbelang te hebben verijdeld -, hebben de protestantse partijen na deze vergeefse zoektocht vrede met Nolens' oorspronkelijke voorkeur, namelijk de katholiek jhr. mr. O. van Nispen tot Sevenaer: hém kennen ze, hij bezit goede kwaliteiten en als voormalig voorzitter van de Tweede Kamer genlet hl] het vertrouwen van alle protestantse politici. Maar helaas, óók Van Nispen geeft niet thuis, en zo'n fraaie geloofsbrief als de tegenwoordige gezant bij het Vaticaan kan overleggen, ontbeert de man met wie Nolens nú komt aanzetten.

De man om wie het gaat is jhr. Charles Ruys de Beerenbrouck, nog maar net benoemd tot Commissaris der Koningin in Limburg en daarvóór dertien jaar lang een verdienstelijk maar niet bijzondler opvallend lid van de 
Tweede Kamer.

Zo'n man mist toch de ervaring, weten de protestantse selecteurs, om doortastend leiding te geven aan een sterk en homogeen kabinet dat er moet komen. En dan diens aristocratische-papo-Limburgse visitekaartje ! Je kunt het wel vergeten dat een jonkheer de sociale kwestie serieus oppakt en zodoende het opkomende socialistische getij keert. Om nog maar te zwilgen van 's mans uitgesproken roomse signatuur die - zo zegt hun een vertwiffeld gemoed - weinig heil belooft voor de kleine huyden, maar des te meer zegen voor diens favoriete katholleke zuiden!

Ruys, dle fanatieke roomse Limburgse gouverneur, premier? Nee, alle benoemingen van burgemeesters en onderwilsambtenaren in diens handen. dát zou "uiterst ellendig" "zijn, en is dan ook onbespreekbaarvoor de AR en de CHU!

Op 19 augustus geeft Nolens zijn opdracht terug aan de koningin. De wegbereider is al een aardig eind op streek, maar zonder een kandidaatpremier is zijn werk op een wezenlijk onderdeel onaf.

\section{* Tussenberaad}

In het tussenberaad dat nu volgt, speelt Colijn een doorslaggevende rol. Hi) komt weer met het idee van een gemengd kabinet onder linkse leiding op de proppen. Maar deze oorspronkelijke optie van de AR stuit op onoverkomelijke bezwaren van de katholieke fractie, en ook de $\mathrm{CHU}$ wil de formatie van een rechts kabinet voortzetten. Klezen voor de gemengde variant betekent dat de RKSP afhaakt, waarna de coalitie wellicht voorgoed uiteenvalt. Bij keuze voor een rechts kabinet bijift de AR en de CHIJ niet veel anders over dan Ruys de Beerenbrouck te accepteren als formateur én premier...

Zoals de zaken er nu voorstaan is het Colijn duidelijk dat de vorming van een rechts kabinet moet worden vervolgd, en breekt hij in de eigen ARkring het verzet tegen een rechts kabinet onder leiding van Ruys. Ook de $\mathrm{CHU}$ laat weten, zich niet te zullen verzetten tegen het onvermijdelijke, al houdt Lohman tot op het laatst vast aan de kandidatuur van de voor de twee andere fracties onacceptabele Heemskerk, om zó aan de "uiterst ellendige" benoeming van Ruys te ontkomen !

\subsection{Ruys rondt af}

Na royale gebruikmaking van het right to consult dat het staatshoofd bij een kabinetsformatie toekomt - Colijn en Idenburg, Lohman en De Geer, 
Nolens en Van Nispen, twee kopstukken per bloedgroep, verschenen de laatste dagen op Het Loo -, ontbiedt Wilhelmina op 29 augustus Ruys in Apeldoorn en geeft hem de opdracht een rechts kabinet te formeren.

Uitvoerig oriënteert de nieuwe formateur zich de volgende dag bij Nolens. Deze wegbereider bezit immers al een blauwdruk van het regeerprogram en een bijna compleet lijstje van kandidaat-ministers, en dat voorwerk mag niet onbenut blijven.

In de eerste bijeenkomst van de kandidaat-ministers op 2 september kost de afwerking van het regeerprogram dan ook weinig tijd. De vergadering verloopt gesmeerd, totdat de beoogde minister van financiën, $\mathrm{mr}$. L. Trip, aan het woord komt. Hij weigert de portefeuille als de toekomstige collega's niet bereid zijn de, naar zijn oordeel, buitensporige defensieuitgaven met minstens $f 100$ miljoen te verlagen en die vervolgens aan een vaste limiet te binden. Dit laatste achten de overige aanwezigen echter niet doenlijk voor het geval dat het landsbelang noodzakelijk hogere eisen zou stellen. ${ }^{12}$

En derhalve moet Ruys op zoek naar een andere kandidaat voor financiën. De zorgelijke toestand van de schatkist vraagt om een minister die van wanten weet, en voor zo'n karwei is het excellente Tweede-Kamerlid jhr. $\mathrm{mr}$. D. de Geer de aangewezen persoon. Maar als blijkt dlat deze finandele specialist zich achter een doktersadvies verschuilt, moet een noodoplossing - de in Haagse kringen onbeschreven Amsterdamse wethouder van financiën $\mathrm{mr}$. S. de Vries - de formatie redden.

Op 5 september heeft Ruys zijn opdracht af. Zijn kabinet stelt zich tot hoofdtaak "de nood der tijden naar vermogen te temperen en de economische toestand te sterken". Daarnaast staan ook de uitvoering van het nieuwe onderwijsartikel van de grondwet, alsmede de invoering van Talma's sociale wetten hoog genoteerd in het regeerprogram. Verder heeft het kabinet ervoor te zorgen dat "de militaire weerkracht van ons land en van Indië zóo zij - en na den vrede zóo worde - als ons onafhankelijk volksbestaan en het behoud van onze Koloniën vorderen." 13

Het duurt nog vier dagen eer Ruys zijn eindrapportage uitbrengt aan de koningin. Hare Majesteit kan wel even wachten, want hoe zal de onberekenbare Kuyper er bij zijn terugkeer van vakantie op reageren dat tijdens zijn afwezigheid, geheel buiten hem om de formatie van een rechts kabinet onder katholieke leiding is afgerond?

Als een hoofse goodwill-ambassadeur maakt Ruys zijn opwachting blj Abraham de Geweldige om " ... van $U$ de verzekering te ontvangen dat op Uw machtigen steun zou kunnen gerekend worden." 14 
Wie formeerde nu eigenlijk dit kabinet? Dat was geheel en al het werk van Ruys, betoogt J. Verhagen in zijn dissertatie over de formatie van 1918. ${ }^{15}$ Naar zlin mening is de formatiearbeid van Nolens mislukt en belandt de vorming van een kabinet als gevolg daarvan in een nieuwe fase die nog alle kanten op kan. Tijdens het tussenberaad vertoeft de ex-formateur in de antichambre waar hij de loop van de gebeurtenissen vol ongeduld en ergernis moet aanzien, zonder er echt vat op te hebben. De formatie van 1918 neemt pas een beslissende wending als Ruys de opdracht krijgt - én er in slaagt - een rechts kabinet onder zijn leiding te vormen.

Anders dan Verhagen is Oud van mening dat Ruys zijn kabinet uit handen van Nolens ontving. Ook al beproeven anderen na Nolens' terugtreden nog alternatieve mogelijkheden, en moet Ruys als formateur nog diverse moeilijkheden zelf klaren, feitelijk is het nieuwe kabinet er een van Nolens zonder Nolens, aldus de erkende parlementaire geschiedschrijver. ${ }^{16}$

Wel zeker was Ruys lets méér dan alleen een "schildknaap of marionet in Nolens" hand", zoals geschriften en spotprenten hem destijds soms voorstelden. G. Puchinger ${ }^{17}$ en J.P. Gribling ${ }^{18}$ wijzen er terecht op dat niet Nolens, maar Ruys de kroon op het formatlewerk zet. Het is immers aan diens tact en geduld toe te schrijven - zijn betoon van respect voor Kuyper, die hem daarvoor beloont met: "Het valt niet in te zien, in welk opzicht [Ruys] nobeler en voorzichtiger had kunnen te werk gaan." ${ }^{\prime 9}$, is daar een voorbeeld van - dat de plooien in de relatie met zijn protestantse coalitiegenoten worden gladgestreken en de ministersposten definitief worden verdeeld en bezet.

Hoe Nolens over een en ander denkt, komt nog aan de orde.

Maar deze hele discussie doet niets af aan de "Jubelzang op het Kabinet" in de socialistische Notenkraker:

"Dit is de Jonkheer Ruys,

Waarschijnlijk per abuis.

Tot Leider aangewezen,

Omdat geen mensch 't wou wezen.

Hij moet van grond op leeren,

Hoe of dat gaat: regeeren !" 


\subsection{Inleiding}

Charles Ruys stamt uit een geslacht dat reeds in de vifftiende eeuw voorkomt in de contreien van Den Bosch. Vanaf het begin van de zeventiende eeuw bekleden achtereenvolgende generaties hoge ambten in het hertogdom Gelre, het vorstendom Thorn en in Venlo.

De meest bekende voorvader is Gerlach Ruys, raadadviseur en rekenmeester in Gelre van koning Filips II van Spanje en de landvoogden Albrecht en Isabella."

Getrouw aan zijn wapenspreuk: "antes morir que ser traidor" - liever sterven dan verraden - moet Gerlach zijn Spanish connections in 1627 met de dood bekopen als hij de hem toevertrouwde overheldsdocumenten weigert over te dragen aan het Staatse leger.

In 1816 wordt Charles' grootvader Edmond Hieronymus benoemd tot lid van de ridderschap van Limburg. De nieuwe jonkheer, gehuwd met Clara Maria Anna Philippina van Aefferden, vrouwe van Beerenbroek (familledomein in Geldern, Duitsland), voegt die laatste naam toe aan zijn geslachtsnaam Ruys.

Vader jhr. mr. Gustave Lodewijk Marie Hubert Ruys van Beerenbroek (1842-1926), geboren in Roermond, huwt in 1872 met ziln Belgische nicht jknw. Marie Isabelle Louise Ruys de Beerenbrouck (1849-1922). Bil vonnis van de rechtbank Roermond van 21 maart 1895 laat Gustave, oudgemeenteraadslid van Maastricht, oud-lid van de Tweede Kamer, oud-minister van justitie in het kabinet-Mackay en van 1893 tot 1918 Commissaris der Koningin in Limburg, zijn familienaam verfransen in: Ruys de Beerenbrouck. ${ }^{2}$

Uit dit huwelijk worden op 1 december 1873 zoon Charles en twee jaar later dochter Louise geboren. Op een gedenkplaat tegen de gevel van rijksmonument Swalmerstraat 13 in Roermond staat te lezen dat dit pand het geboortehuis is van een "overtuigd christen en staatsman".

\subsection{Jeugd en studietijd}

In 1877 verhuist de familie Ruys naar Maastricht, waar vader Gustave 
rechter wordt. De kinderen groelen op in een harmonieus, degelijk katholiek en in sobere still levend gezin. Hun opvoeding is doortrokken van geloofsiliver en plichtsbesef. Dagelifikse kerkgang hoort tot het vaste leefpatroon. En al vroeg laten de ouders hun kinderen ook de keerzlide van hun bevoorrechte bestaan zien.

Charles en Louise zitten nog maar op de lagere school als vader Ruys hen al confronteert met de erbarmelikke toestanden in de sloppenwiliken en de gevangenis van Maastricht. De oude Ruys, een geboren regent, wordt door dr. E. Kimman ${ }^{3}$ getypeerd als lemand met een politieke attitude vergelijkbaar met die van de Engelse adel. Een Tory dus, met een open houding voor veranderingen. Als Tweede-Kamerlid die de sociale noden van nabil kent, is hil in 1886 mede-indiener van een voorstel om een parlementaire enquête te houden naar de situatie van de arbelders in fabrieken en werkplaatsen. De enquêtecommissle, waarvan de edelman lid is, brengt ongelofelijke misstanden, met name in de fabrieken van de Maastrichtse inclustrieel Regout, aan het licht. Eenmaal minister van justitie, verbindt Ruys senior in 1889 zijn naam aan de eerste arbeldswetgeving van Nederland.

Thuis maakt vader Gustave zlpn zoon Charles deelgenoot van de maatschappellike problematiek. Charles is uitermate ontvankelijk voor die vraagstukken: zijn dlepe geloof en sterke rechtvaardigheidsgevoel blikken de krachtbron te ziln van zilin grote sociale en politieke dadendrang van straks.

De benoeming van Gustave Ruys tot minister brengt mee dat het gezin in 1888 naar Den Haag vertrekt. Charles zet zijn op het Stedelijk Gymnasium in Maastricht gestarte opleiding voort op het Haganum in Den Haag en doet in 1892 samen met klasgenoot en toekomstige collega jhr. H.A. van Karnebeek eindexamen. In dat jaar gaat hij rechten studeren in Leiden. Hij wordt in oktober lid van het Leids Studentencorps na een nogal rumoerige inauguratieplechtigheid. Charles verzet zich namelijk tegen het ritueel dat aspirant-corpsleden de groet aan het corpsvaandel moeten bevestigen door een kniebuiging. "lk kniel alleen voor God", verstout de noviet zich, en daar heeft zelfs Minerva van die dagen niet van terug!

Met latere coryfeeën als de politicus P.J.M. Aalberse en de eminente staatsrechtsgeleerde A.A.H. Struycken neemt geheelonthouder en nietroker Ruys in 1893 het initiatief tot de oprichting van een katholieke studentenvereniging in Leiden. Piet Aalberse is de stuwende kracht achter dit plan. Zlin eerste kennismaking met Charles Ruys bevalt hem best: “... een uitstekende kerel, met wie ik het goed zal kunnen vinden; jammer dat hij niet wat gemakkelijker spreekt, doch dat zal hij wel aanleren... " ${ }^{4}$ De ou- 
derejaarsstudent in de letteren, later bekeerd tot de rechtenstudie, laat aan "zwaargewicht" Charles - spijtig genoeg geen spraakwater, maar wèl zoon van een oud-minister en bovendien van adel - de eer om de eerste preses van de RK Studentenvereniging, nadien "Sanctus Augustinus" geheten, te worden. ${ }^{5}$ Werken aan een nieuwe inrichting van de maatschappij zit er bij deze twee studenten al op jonge leeftlid in!

Op 17 december 1895 rondt Ruys zijn studie af met een proefschrift over "Het Strafrecht in het Oude Maastricht", ongetwiffeld een reminiscentle aan het gevangenisbezoek in zijn prille jeugd.

\subsection{Sociaal en politiek dubbelleven}

Begin 1896 vestigt Charles Ruys zich als advocaat en procureur in Maastricht. Dit tweede Limburgse tijdvak is er een van groot maatschappelijk engagement. Zijn stuwende en sturende activitelten op een breed sociaal terrein, aanvankelijk in Maastricht, later in heel Limburg, maken hem tot een van de grondleggers van de maatschappelijke organisatles in deze provincie.

In 1897 wordt de jonge advocaat juridisch adviseur van de twee oudste katholieke vakverenigingen - van aardewerkers en glasbewerkers - in Maastricht. Al gauw raakt hilj overtuigd van het belang dat de katholieke arbeiders zich aaneensluiten. Mede op zijn initiatief komen in 1899 de Maastrichtse Volksbond en in 1900 de Limburgse koepel van alle be: staande vakorganisaties tot stand en neemt Ruys in beide bonden belangrijke functies op zich.

Buiten de Volksbond blijft de Centrale Bond van RK mijnwerkers, die onder impuls van de uit Venlo afkomstige priester-parlementariër Willem Nolens in 1903 het leven ziet. In die tijd werken veel Limburgse "koempels" in Duitse milnen en zijn daar interconfessioneel georganiseerd. $\mathrm{Er}$ is een krachtig pleidool van Nolens èn Ruys voor nodig eer het bisschoppelijke paleis in Roermond in 1907 bewilligt in de oprichting van de Algemene Bond van Christellike Mijnwerkers in Nederland.

Eind 1897 raakt Ruys diep onder de indruk van een lezing over drankbestrijding die Alphons Ariëns (1860-1928) in Maastricht houdt. Na het klemmende betoog van deze in Twente werkzame priester-plonler van de Nederlandse katholieke arbeidersbeweging staat voor Charles, toch al geen kroegbezoeker, vast dat "... een goed volk van den drankdulvel moet worden verlost ..." ${ }^{6}$ Op instigatie van beide drankbestrijders komt in 1898 de katholleke vereniging voor drankweer, Sobrletas, tot stand, waarvan Ruys tot 1918 landelijk voorzitter is. 
Ook treedt Ruys op velerlel ander terrein op de voorgrond. Zo behoort hij in 1903 met Aalberse tot de oprichters van de Katholieke Sociale Actie, en is hij tot 1912 voorzitter van dit overkoepelende orgaan van sociale organisaties. Mede aan hem is tevens de oprichting van het Limburgse Groene Kruis in 1910 te danken. En alweer is Ruys ook van deze instelling van gezondheidszorg voorzitter. Dat daarnaast de katholieke Vroedvrouwenschool in Heerlen (1911), de RK Reclasseringsvereniging, plaatselijke EHBO-cursussen en talrijke overige sociale zorg mede op Ruys" initiatief van de grond komen, demonstreert op welk breed scala aan acties hij zijn stempel drukt.

Prominent is bovendien zijn rol in de gemeenteraad van Maastricht, waar hij van 1899 tot mei 1918 onafgebroken lid van is.

$\mathrm{A}$ in de eerste vergadering na zijin installatie als raadslid dringt Ruys aan op verbetering van de rechtspositie van de ambtenaren en de werklieden in dienst van de gemeente. Wat zullen we nou krilgen ?, sissen de vroede vaderen, en geven het groentje in hun afhoudende weerwoord te verstaan dat hij zelf maar met voorstellen moet komen. Initiatieven blijven niet lang uit. Eerst lanceert hij een ontwerp van een pensioenregeling voor het gemeentepersoneel en vervolgens concipieert hij een ambtenarenreglement en bepalingen voor minimumloon en maximale arbeidsduur in gemeentebestekken. De gemeenteraad voelt aanvankelijk weinig voor die vooruitstrevende ideeën van Ruys, doch gaat na diens hardnekkige en soms ongekend felle verdediging van de ontwerpen overstag. Aldus helpt Ruys in de beginjaren van zijn raadslidmaatschap Maastricht als een van de eerste gemeenten in Nederland aan een drietal sociale verordeningen.

Een actief aandeel heeft hil daarnaast ook in de bestrijding van de werkloosheid en de woningnood in Maastricht: op zijn voorstel komen onder meer een gemeentelijk werklozenfonds en voorzieningen op het gebied van de soclale woningbouw tot stand. En zo gaat die "roeje" Ruys steeds maar door, |ammeren de liberale stadsregenten, "de Raad gaat langzamerhand de socialistische weg op"... ${ }^{7}$

Op 15 april 1902 huwt Charles Ruys in Warnsveld met jkww. Maria josephina Ernestina Alexandrina van der Heijden (1877-1948), vrouwe van Suideras (familiedomein in Vierakker, gemeente Vorden in Gelderland).

Zij krijgen drie kinderen, Maria (1903-1999), Gustave (1904-1983) en Joanna (1910-1992). In hun opvoeding weersplegelt zich de lijn van denken en leven van de ouders: zonder overdaad, sociaal, breed èn katholiek, zelfs "héél katholiek zou ik haast zeggen", herinnert de eerstgeborene zich. ${ }^{8}$ 
De oudste dochter huwt nadien met jhr. mr. C.M.O. van Nispen tot Sevenaer; de jongste dochter met I.J.G. baron van Voorst tot Voorst; de zoon met vrouwe M.M.C.Ph.H.G. barones de Loë.

Na een zware kamp met een kandidaat van het "Zuid-Limburgse bierkapitaal" wordt Ruys in 1905 namens het kiesdistrict Gulpen lid van de Tweede Kamer. Het dubbelleven van een tweevoudig volksvertegerwoordiger breekt aan. In een dertien jaar durende pendeldienst tussen Maastricht en Den Haag doet hij zich kennen als een toegewijd en degelijk lid van de katholieke kamerclub, hoewel minder opvallend dan in de gemeenteraad van zijn woonplaats.

Met enorme werkkracht blijft politicus Ruys daarnaast zijn aandacht widen aan talloze maatschappelijke functies. Hij neemt veel hool op zijn vork, te veel zelfs, zoals in 1910 blijkt. Wegens zware overspanning is hij een vol jaar uit de running, maar "leven zonder te werken, dat kan lk nlet". Bij het uitbreken van de Eerste Wereldoorlog krijgt hij in 1914 de taak als regeringscommissaris de opvang en de verzorging van de Belgische vluchtelingen in Zuid-Nederland te regelen.

Amper veertig jaar oud is Ruys een naam om te onthouden. Zeker nu de katholieke edelman zich inmiddels ook mag verheugen in de gunst van koningin Wilhelmina, die hem in 1913 benoemt tot haar kamerheer in bultengewone dienst.

In mei 1918 volgt Charles Ruys zijn vader op als Commissaris der Koningin in Limburg. De gouverneur is nog geen vier maanden in functie, of hij moet: "Optredende als Voorzitter van Harer Majesteits Ministerle mijn ambt van Commissaris der Koningin in Uwe Provincie vaarwel zeggen. Gij weet hoeveel mij dit kost; waar 's lands Vorstin mil persoonlijk riep en de formatie opdroeg, zou ik mijn plicht niet begrijpen, indien ik zonder geldige reden weigerde aan den wensch van Hare Majesteit gevolg te geven" " schrijft hij in zijn afscheidsbrief aan Gedeputeerde Staten.

Met plin in het hart vertrekt Charles Ruys uit zijn Limburg, het oord ook waar hij zijn ouders achterlaat. Overigens heeft het Haagse gezin Ruys jarenlang een rlant pied-à-terre in Kasteel Wolfrath in het Limburgse Holtum, waar de oude Ruys en zijn echtgenote hun intrek hebben genomen. Tot 1983 is een Ruys - Gustave junior sluit de ril - kasteelheer van dit uitgestrekte landgoed, dat tegenwoordig sombert in de schaduw van een multinationale autofabriek in Born. ${ }^{\prime}$ 


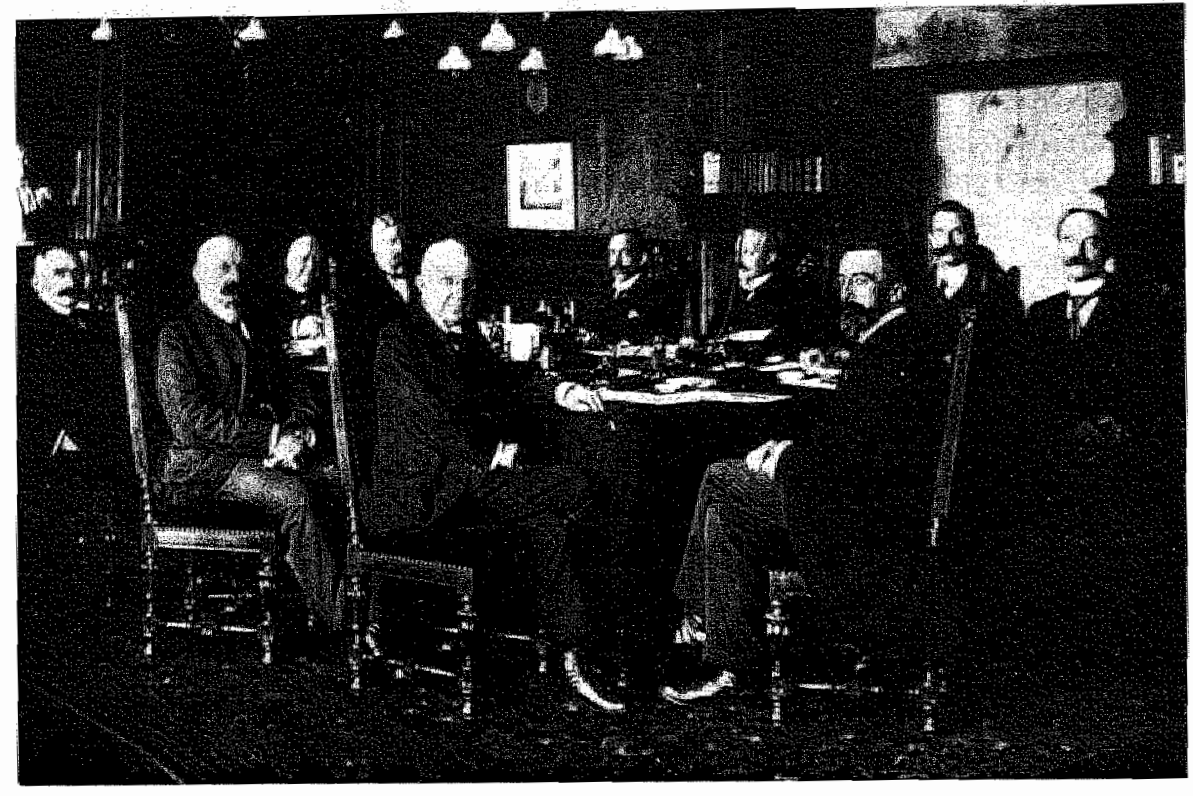

\section{HET EERSTE KABINET-RUYS}

V.I.n.r.: S. de Vries, W. Naudln ten Cate (schuin achter De Vries). G. Alting von Geusau, J. de Msser, Th. Heemskerk, H. van IIsselsteijn, H. van Karnebeek, Ch. Ruys, P. Aalberse, A. König en A. Idenburg. 


\section{HET EERSTE KABINET-RUYS DE BEERENBROUCK (1918-1922)}

\subsection{Inleiding}

Op 9 september 1918 gaat het kabinet-Ruys van start. Alleen ziln er nog geen ministers van arbeid en onderwijs, die pas bij de instelling van hun nieuwe ministeries op 25 september aantreden.

Het nieuwe kabinet gaat een zwaar beladen regeerperiode tegemoet. Het krijgt aanstonds te maken met de dreigingen van oorlog en revolutie. Zodra deze vuurproef achter de rug is, pakt het in ongekend snel tempo de hervorming van het sociale stelsel aan en brengt het tevens de nieuwe wet op het lager onderwijs tot stand.

Vervolgens heeft het kabinet te kampen met ernstige financiële en militaire problemen, die in 1921 tot een kabinetscrisis leiden. In gereconstrueerde vorm keert het kabinet terug, waarna het in zijn laatste zittingsjaar toekomt aan de sinds 1918 voorberelide herziening van de grondwet.

Alvorens deze gebeurtenissen onder de loep te nemen, staan we even stil bij de nieuwe ministersploeg, die een bonte mengeling van professionals en nieuwelingen in het politieke vak vormt.

\section{* Samenstelling van de ministersploeg}

Als het eindelijk zover is dat de AR en de $\mathrm{CHU}$ hun verzet tegen de formatie van een kabinet-Ruys opgeven, verklaart een aantal prominente protestantse politici zich meteen ook bereid regeringsverantwoordelijkheid te dragen.

De antirevolutionair A. Idenburg, gouverneur-generaal van NederlandsIndië, was reeds minister van koloniën in de kabinetten van Kuyper en Heemskerk, en aanvaardt dit ambt nu voor de derde maal. Zijn partligenoot $\mathrm{mr}$. Th. Heemskerk komt op justitie. Als voormalig wethouder van Amsterdam en meer nog als premier van het derde coalitiekabinet kan hilf evenzeer bogen op een rijke politieke ervaring. Bovendien zijn staatszaken hem door zijn vader met de paplepel ingegeven.

De vroegere leider van de Christelijk-Historische Kezersbond, dr. J. de Visser, is de belangrijkste vertegenwoordiger van de christelijk-historische richting in het kabinet. Met deze hervormde predikant, thans voorzltter 
van de CHU en sinds 1897 onafgebroken lid van de Tweede Kamer, komt cok de gevoelige portefeuille van onderwijs, in combinatie met kunsten en wetenschappen, in handen van een man van formaat.

Met Ruys is Aalberse de meest vooraanstaande katholieke minister in het kabinet. In 1903 verwisselde hij zi|n wethouderschap voor sociale aangelegenheden in Leiden voor het lidmaatschap van de Tweede Kamer, waar hij dr. H. Schaepman namens het kiesdistrict Almelo opvolgde. In 1916 verllet hil de kamer om hoogleraar arbeidswetgeving en handelsrecht aan de Technische Hogeschool in Delft te worden. Als mede-oprichter en motor van het Katholiek Sociaal Weekblad en de Katholieke Sociale Actie een exponent van de progressieve vleugel in de staatspartij, is hil dé aangewezen persoon voor het nieuwe ministerie van arbeld.

Ook de minister van buitenlandse zaken past in de rij van ervaren bestuurders. Dr. Van Karnebeek, een partijloze telg uit een liberaal regentengeslacht en tot voor kort een beoogd "linkse" minister in een eventueel gemengd kabinet, maakt, bij gebrek aan een geschikte "rechtse" kandidaat voor de betrekkingen met het buitenland, zijn overstap van burgemeester van Den Haag naar het kabinet van zijn oude studiegenoot Ruys.

De post financlën is, zoals we reeds zagen, voor De Vries (AR), en verder telt de ministersploeg in ir. A. König (RK; waterstaat), jhr. G. Alting von Geusau (RK; oorlog). H. van IJsselsteljn (christelijk-historisch; landbouw, nijverheld en handel) en W. Naudin ten Cate (christelijk-historisch; marine) vier politieke debutanten.

Blijft over de naamgever van het kabinet. Bil zijn aantreden als premier is Ruys nog maar $\mathbf{4 4}$ jaar, hetgeen hem de jongste eerste minister maakt die ons land sinds Thorbecke tot hier toe kende. Het parlementaire werk in Den Haag en de sociaal-politieke actie in Limburg waren een goede leerschool voor hem, zo te zeggen: de opmaat tot het premierschap, dat hem nu nolens volens is toegevallen. Ruys neemt binnenlandse zaken voor zijn rekening, betrekt het fameuze Torentje van Thorbecke en weet zich in zijn coördinerende rol van voorzitter van de ministerraad al direct aanmerkelijk gesterkt door een koninklijk besluit van 13 september 1918, dat elke minister verplicht met hem overleg te voeren over zaken waarbij het algemeen regeringsbeleid kàn zijn betrokken.

De nleuwe ministersploeg is "op zeer presentabele wijze" samengesteld, oordeelt Colijn met welgevallen. En met een welhaast lyrische ontboezeming noemt Nolens het tableau de la troupe onverbloemd zijn werk: "Het kabinet is er en het mag er zijn, al zeg ik het zelf, zou ik er bijna bijvoegen ... de heren kunnen mij dankbaar zijin, dat ik het optreden van een parlementair kabinet mogelijk heb gemaakt." 2 


\subsection{Vuurdoop}

Herziening van de schoolwet en realisering van een omvangrijk soclaal plan, dát zijn de hoofdpijlers van het regeerprogram, die de troonrede van 1918 aankondigt.

Ter uitvoering van het gewijzigde artikel 192 van de grondwet will de regering onverwijld en "in de geest van onderling vertrouwen, die de herzlening heeft gekenmerkt" komen tot de financiële gelijkstelling van de bi zondere met de openbare lagere school.

Naast de afsluiting van de veelbesproken onderwijskwestie stelt de troonrede prompte invoering van Talma's sociale wetten - door de oorlog zilin die blijven liggen - èn verdere uitbreiding van arbeidswetgeving en sociale verzekering in uitzicht.

"Ik heb eens nagegaan, wat ik zou willen doen", noteert Aalberse op 9 augustus 1918 in zijn dagboek. ${ }^{3}$ Achttien punten telt het werkplan dat de kandidaat-minister op 31 augustus aan formateur Ruys voorlegt. De beoogde minister van arbeid will alleen zitting nemen in het kabinet als hij de ruimte krijgt voor maatregelen als: instelling van een Hoge Raad van Arbeid, invoering van de 8-urige werkdag voor volwassen mannen, herzlening van de ziekte-, ongevallen- en invaliditeitswet, een verplichte ouderdomsverzekering van de arbeiders en een uitbreiding daarvan tot niet-arbeiders, alsook terugdringing van arbeidsgeschillen. Ruys stemt hler volledig mee in, want, net als zijn politieke vriend, leeft ook hil onder de tucht van de sociale encycliek Rerum Novarum van $1891^{4}$, die binnen de RKSP als grondwet van het sociaal-politieke handelen geldt.

De troonrede maakt verder nog gewag van de bijzondere maatregelen die cle regering nodig acht vanwege de nijpende internationale en nationale situatie. Dat zou een voorgevoel van een vlammende vuurdoop blijken te zijn ...

\section{* Nadagen van de oorlog}

Zomer 1918 brengt de definitieve ommekeer op het westelijke oorlogsfront. De geallieerden pareren de aanhoudende voorjaarsoffensieven van de Duitsers en zetten - met gewapende tussenkomst van de Verenigde Staten - hun eindoffensief in.

Duitsland beseft dat de nederlaag nabij is, de bevolking is de lasten en ellende van de oorlog meer dan beu. Op 4 oktober verklaart de keizerlike regering - die inmiddels een bescheiden democratische transformatie achter de rug heeft - zich bereid tot vredesonderhandelingen en onmiddellijke staking van de vijandelijkheden. Een maand later, als de Entente 
nog steeds niets voelt voor onderhandelingen met keizer Wihelm II en zijn regering, slaat de Duitse vloot in Kiel aan het multen.

Dit oproer van het krijgsvolk is het begin van revolutionaire woelingen die zich snel over het land uitbreiden. Overal vormen zich raden van arbeiders en soldaten die de macht in stad en land overnemen. De revolutiegolf overspoelt ten slotte ook de hoofdstad, waar de keizerlijke regering bezwijkt onder de druk van het volksfront.

Op 9 november roept Philipp Scheidemann - bijtijds hield deze socialist het zinkende regeringsschip na een ambtstermijn van amper een maand voor gezien - in Berlijn de republiek uit en vlucht de kelzer naar Nederland. Twee dagen later accepteert de nieuwe socialistische regering-Ebert de wapenstilstandsvoorwaarden en komt er een eind aan die verschrikleIljke grande guerre.

Oók Nederland gaat in de nadagen van de oorlog gebukt onder kommer en kwel. Als neutrale staat zit ons land klem tussen de oorlogvoerende partijen. Blokkades van de geallieerden en de duikbootoorlog van de Duitsers leggen de scheepvaart op zee nagenoeg lam, met alle gevolgen voor de aanvoer van levensmiddelen en grondstoffen van dien. Brede lagen van de bevolking lijden honger en armoede, er heerst grote werkloosheid. De oorlogsdreiging is zo dichtbil dat aan verlenging en uitbreiding van de reeds vier jaar durende en geldverslindende mobilisatie niet valt te ontkomen.

De burgers zuchten onder de strenge rampspoed, leger en vloot morren. Als in de loop van 1918 het broodrantsoen voor de zoveelste keer wordt verlaagd, breken op diverse plaatsen wanordelijkheden uit. Hier en daar moet men zelfs militairen inzetten om de orde te herstellen.

Het kabinet-Ruys is nog maar nauwelijks van de partij of het krijgt op zijn beurt te maken met een reeks van ongeregeldheden. Op 25 oktober komt het in het leger tot een uitbarsting. Uit ontevredenheid over het intrekken van verloven en over de slechte voeding rebelleren de soldaten in de Harskamp tegen de leiding van het legerkamp. Deze brandhaard leidt ook elders tot rellen.

Als de Tweede Kamer het kabinet op 5 november over de militaire situatie Interpelleert, wijst Ruys onmiddellijke demobilisatie als zelfmoord voor ons land van de hand.

Vervolgens breekt Troelstra in zijn interpellatie de staf over de legerleiding en eist In revolutionaire taal: "als de regering deze man niet afzet, dan moet de regering zelf afgezet worden" 5 , het ontslag van opperbevelhebber Snilders.

Oorlogsminister Von Geusau hoort de socialist geduldig aan. Maar een 
dag later - het onheilspellende nleuws over de muiterij in Klel en de revolutionaire roes in Duitsland is inmiddels kennelijk ook tot Den Haag doorgedrongen - kondigt de minister reorganisatie van het leger en officierskorps én ... het gedwongen ontslag van de hoogste militair aan.

De komende dagen blijkt dat Troelstra en andere sensibele geesten binnen de SDAP in de heersende onlusten de tekenen van een revolutionair klimaat ên het sein tot machtsovername vermoeden.

\section{Revolutionair Klimaat}

Bij het ochtendkrieken van zondag 10 november meldt zich een niet-alledaags gezelschap bij de grenspost in Eijsden. Niemand minder dan Wilhelm von Hohenzollern met zijn escorte klopt aan bij het Witte Huis, en meteen is Nederland in rep en roer.

Even later krijgt Ruys een telegram uit Maastricht dat hem het onzalige nieuws van de onverhoedse komst van de ex-keizer brengt.

Prompt komt de premier in actie. Met een paar leden van het kabinet bespreekt hij die ochtend wat er met de hoge asielzoeker moet gebeuren. En petit comité besluit men Wilhelm toe te laten en een voorlopig verblijf voor hem te zoeken in kasteel Amerongen van graaf Bentinck. En met het levende bewijs in handen dat met de uit het Duitse militaire hoofdkwartier in Spa naar Nederland gevluchte ex-keizer de wapenstilstand voor de deur staat, kondigt Ruys - daartoe gemachtigd in de ministerraad van 8 november - nog zondagavond gedeeltelijke demobilisatie af.

Al vroeg is óók Troelstra die zondag op de hoogte van hèt nieuws van de dag. "Geen andere gebeurtenis heeft in ons land een zoo grooten indruk gemaakt als de vlucht van den Duitschen keizer over onze grens. De val van dezen machthebber was het symbool van de ineenstorting der oude wereld", schrijft hij later ${ }^{6}$, maar op dít moment staat hem lets anders te doen dan reflecteren.

In de overtuiging dat de rebellie in de Harskamp - naar het voorbeeld van de muiterij in Kiel - het begin van de revolutie is, waarbij de overheid nlet meer kan rekenen op het leger en de politie, spoedt Troelstra zich naar het socialistische bolwerk Rotterdam.

Op zijn initiatief komen zondagavond de besturen van de SDAP en het socialistische vakverbond, het NW, alsmede de socialistische leden van de Tweede Kamer en de Rotterdamse gemeenteraad in vergadering bijeen. Besloten wordt op 16 en 17 november een congres te houden, morgen een programma van eisen te publiceren en vooralsnog - tot hevige teleurstelling van Troelstra - af te zien van revolutionaire daden. 
Maandagochtend 11 november verschijnt het program van eisen in een manifest van de SDAP en het NW aan de Nederlandse kameraden. Het eisenpakket is zwaar en bevat onder meer: socialisatie van alle bedrijven die daarvoor in aanmerking komen, dekking van alle crisisuitgaven en sociale maatregelen door heffingen ten laste van het grootkapitaal en het grootgrondbezit, invoering van staatspensionering op 60-jarige leeftijd, onverwijlde invoering van de wettelijke 8-urige werkdag, volledige werklozenzorg onder beheer van de arbeidersorganisaties, afschaffing van de Eerste Kamer en onmiddellijke invoering van algemeen vrouwenkjesrecht.? Maar met frases als: "... Hoedt u voor onberaden stappen... Wacht af en houdt u bereid voor het parool, dat het congres u zal geven...", wekt het manifest niet de indruk dat men de claims stormenderhand wil afdwingen. Troelstra - hij was geen lid van de programmacommissie - neemt aangenaam verrast kennis van de geformuleerde eisen. In opgetogen stemming over de revolutionaire betekenis die hij aan het manifest toekent, voert hij die avond het woord tijdens een door de SDAP belegde vergadering in het Verkooplokaal te Rotterdam.

"... Wat is een revolutie ? Dat een heerschende klasse, die totnogtoe de macht in handen had, afdankt, en plaats maakt voor de nieuwe klasse, die rijp, in staat is, te doen wat de omstandigheden eischen. Zoo gezien, is in Nederland op dit oogenblik een revolutionaire toestand ingetreden. Hij plaatst de arbeidersklasse voor een geweldige taak. Verzuimt het oogenblik niet, grijpt de macht, die u in den schoot wordt geworpen... Wij maken een revolutie omdat het kan en moet... ik heb twintig jaren geleden onder het langzame gesukkel van het parlementaire stelsel, niemand heeft een zoo vervloekten hekel aan die langzaamheid als $\mathbf{k}$... Wij zullen dus Zondags [tijdens het congres] de gewichtige vraag hebben te bespreken, of wij zullen overgaan tot een oppersten raad van arbeiders en soldaten voor het heele land, en verder van plaatselijke raden. Hebben wij daartoe besloten, dan is die raad van af dat oogenblik het opperste gezag van ons land... laat er eenmaal worden gezegd: het Nederlandsche proletariaat toonde zich berekend voor zijn taak, de Nederlandsche proletarische revolutie is geweest het gloriepunt in de geschiedenis van Nederland !", zijn de woorden waarmee Troelstra het aanstaande congres onomwonden oproept de revolutie te proclameren. ${ }^{8}$

\section{* Troelstra's revolutionaire kamerrede}

Het nieuws van de revolutionaire rede van Troelstra in Rotterdam gaat als 
een lopend vuurtje door het land zodra de ochtendbladen van 12 november verschijnen. Een golf van verontwaardiging breekt los. Zelfs in het socialistische kamp is men niet onverdeeld ingenomen met Troelstra's act: naast grote bijval oogst de agitator ook forse kritiek op zijn eigenmachtige optreden.

De gebeurtenissen van de laatste dagen laten ook het kabinet niet onberoerd. We zagen reeds dat Ruys met enige getrouwen op zondag druk bezig was met de keizerskwestie en de afkondiging van gedeeltelijke demobilisatie. Maandagochtend komt de ministerraad in buitengewone vergadering bijeen. Ruys doet verslag van de gang van zaken op zondag, en als reactie op zijn mededelingen over de gisteren gehouden socialistische vergadering in Rotterdam wordt besloten dat de premier een regeringsverklaring zal afleggen bij de hervatting van de debatten in de Tweede Kamer op dinsdagmiddag 12 november.

In een zinderende sfeer - de spanning in de vergaderzaal is om te snljden en de publieke tribunes zijn propvol - legt $\mathbb{R} u y s$ die dinsdagmiddag - van het socialistische manifest met eisenpakket is hij inmiddels uit de krant op de hoogte - zijn verklaring af waarin hij verbetering van de voedselvoorziening aankondigt, maar: "Van het grootste belang is dat vóór alles de orde gehandhaafd blijft ... dat geen ordeverstoringen de werkzaamheid der Overheid belemmeren... Voor de eischen van den nieuwen tijd mag niemand ongevoelig zijn; in verdere geregelde samenwerking tusschen Regeering en Volksvertegenwoordiging, gekozen door het Nederlandsche volk, kunnen die vraagstukken aan de orde worden gesteld en worden beslist, maar gewelddadigheden, in elken vorm ook, kunnen daarbi] niet anders dan storend werken." ${ }^{9}$

Urenlang is vervolgens Troelstra aan het woord. Geheel op de Rotterdamse toer hekelt hij "... uw burgerlijk stelsel ... langzamerhand vermolmd en verrot ... verloren het staatsrechtelijke recht om zich te beschouwen als de aangewezen behartigers van de belangen des volks ..." 10 Opnieuw maar nú met de extra impact van de bijzondere plaats en tijd - verkondigt Troelstra de revolutie, opnieuw wijkt hij daarmee af van de lijn van de leiding van de SDAP, en opnieuw laten deze weinig alerte partijbonzen hem begaan.

Meteen na afloop van de hectische kamerzitting komt de ministerraad weer bijeen. Het gezelschap moet eerst wel even bekomen van de aandoening, maar neemt weldra krachtig stelling. "Over "t algemeen waren we kalm ... We moesten veel troepenmacht vertoonen, zoo spoedig mogelijk. Alle regeeringsgebouwen, stations, gas- en electriciteitsfabrileken 
moesten door militairen worden bewaakt, terstond. Dit zou de oproermakers afschrikken, die zouden zien, dat van een onbloedige revolutie geen sprake zou zijn ... Wat een dag is dat geweest. Ik vergeet hem nooit " zoolang ik leef", tekent Aalberse in zijn dagboek aan. "I

En Ruys, welke indruk maakt deze dolle dinsdag op hem ? De bronnen laten zich er niet over uit. Men mag echter aannemen dat de opruiende rede van Troelstra niet langs zijn koude kleren afglijdt, maar de alom heersende commotle brengt hem niet van zijn stuk. Door zijn flinkheid van karakter - kenners was die eigenschap al eerder opgevallen - èn aangeboren optimisme blijft hij de precaire situatie de baas.

Na een aanvankelijke rumor in casa zet de premier het kabinet op het eensgezinde spoor van krachtig ingrijpen. "In ons land loopen er veel pessimisten rond. Hun pessimisme werkt bij mij in tegengestelde richting... Ik heb zoo het gevoel, om niet te zeggen de zekerheid, dat het Kabinet er sterker voorstaat, indien er een weinigje beroering binnenslands is...", vertrouwt een onderkoelde Ruys zijn vriend Van Nispen ooit toe. ${ }^{12}$

Dat het kabinet inmiddels mag rekenen op de grootst mogelijke steun van het - burgerlijke deel van het - parlement en van met name de katholieke valkbeweging, geeft vandaag nieuw voedsel aan Ruys' optimisme over het welslagen van de handhaving van gezag en orde.

\section{* Reactie van de kamer en Ruys}

Er volgen drie dagen van topspanning in de Tweede Kamer. Een koor van sprekers uit rechtse en linkse hoek verklaart dat sociale en economische hervormingen dringend nodig zijn, maar dan wèl langs wettige weg. Fel kanten diverse woordvoerders zich tegen Troelstra. "Gij gooit ons met Duitsche boeken om het hoofd, neemt een voorbeeld aan de organisatie van de Pruisische sociaal-democraten, wil[ $[t]$ thans nadoen wat de Pruisische sociaal-democraten doen, die ondanks het wegzenden van den kelzer militaristen zijn in merg en been ... Maar ik wil zeggen", vervolgt Marchant, "dat gij op het punt staat een vreeselijke verantwoordelijkheld op $u$ te laden, en dat gil uw voornemen moet volbrengen alleen. Buiten de SDAP hebt gij slechts tegenstand te verwachten ..." 13

De bijtende woorden van de vrijzinnig-democratische spreker treffen doel: "Ik begon meer en meer pijnlijkk te beseffen, dat ik te ver was gegaan", schrijft Troelstra later. ${ }^{14}$ Ook in de SDAP en het NW groeit de kritiek op Troelstra's onstuimige optreden en begint de revolutionaire stemming snel te verflauwen.

Intussen volgt de apostel van de nieuwe orde aandachtig maar zwijgend de debatten in de Tweede Kamer. De vrij-liberaal mr. H. Dresselhuys lokt 
hem uiteindelijk met: "De heer Troelstra heeft in deze Kamer gezegd, dat hij zou doen een staatsgreep...", uit ziln tent. ${ }^{15}$

De bellaagde voorzitter van de sociaal-democratische fractie interrumpeert heftig: "Het woord staatsgreep is door mil in het geheel niet gebruikt. De heeren hebben zich een paar dagen opgewonden over voorstellingen, die volstrekt niet beantwoorden aan hetgeen in deze Kamer door mil uitdrukkelijk is gezegd." ${ }^{16}$ En met deze uitspraak laat hij vervolgens de heren - en wellicht ook het enige vrouwelijke kamerlid - op 14 november sprakeloos én opgelucht huiswaarts gaan...

Volkomen uitgeput laat Troelstra de volgende dag verstek gaan in de kamer. Plaatsvervangend fractieleider J. Schaper, juist een van de grootste tegenstanders van Troelstra's revolutiepoging, valt de "eer" te beurt diens terugtocht te dekken. Na veel tactische omhaal van woorden bekent de gekwelde spreker ten slotte: " ...wil dreigen niet, wij zullen ons best doen, maar doe gij dat dan ook ..." 17

Keren we nu weer terug naar de regeringstafel. Op 13 november, daags na Troelstra's geruchtmakende optreden in de kamer, verklaart Ruys dat de regering bereid is met voortvarendheid de sociale hervormingen ter hand te nemen. Dat het de regering ernst is met haar stellige belofte blijkt een week later opnieuw als de premier de kamer aan het slot van de beraadslagingen verzekert: "ledere zucht tot conservatisme is haar vreemd, tenzij dan wanneer het geldt de grondslagen van ons maatschappelijk en politiek leven te beschermen, met name de souvereiniteit van het Huis van Oranje nevens de democratische instelling onzer Volksvertegenwoordiging en de daarbij passende parlementaire verantwoordelijkheid in het Kabinet." ${ }^{18}$

Tevens stelt Ruys in zijn regeringsverklaring van 13 november ontbinding van de Tweede Kamer in uitzicht en schenkt hij bijval aan spoedige invoering van het vrouwenkiesrecht. Kamerontbinding ? Daar repte anders de troonrede met geen woord van ! Maar de kamer weet dan ook nlet dat het regeerprogram dat middel tot versterking van de parlementalire basis van het kabinet wèl in gedachte houdt. ${ }^{19}$

Oók Ruys" adhesiebetuiging met het vrouwenklesrecht baart veel opzien in de vergadering, en wel in dit geval vooral achter de regeringstafel ... Want zonder overleg met zijn collega's schiet hij een bres in: "Vrouwenkjesrecht worde niet door het Kabinet voorgesteld" - een beleidsuitgangspunt dat onder zware druk van de AR en de CHU in het regeerprogram is opgenomen - en omarmt nu pardoes een initiatiefvoorstel-Marchant dat twee maanden geleden de oppositionele reactie was op het passleve regeringstandpunt over deze kwestie. 
Vanwaar die ommezwaai van Ruys, waarmee hij zich de hoon van sociaaldemocrate Suze Groeneweg - "de regering verschuilt zich achter vrouwenrokken" ${ }^{20}$ - op de hals haalt ? Natuurlijk rekent Ruys ook wel op een samenhang van vrouwen-naar-de-stembus en versterking van het draagvlak van zljn kabinet. Maar als veranderingsgezinde ijveraar voor een regeerprogram van sterk sociaal gehalte grijpt de premler de algemene roep om grote maatschappelijke hervormingen, die in november opklinkt, aan om die hervormingen met kracht door te zetten en aan te vullen.

Hij schat daarbij in dat het klimaat voor ingrijpende veranderingen, óók voor het vrouwenkiesrecht, in zijn politieke achterban gunstig is. Dit kiesrecht is immers binnen de RKSP geen kwestie van ideologie - zoals in de kamerdebatten van 1916 over de grondwetsherzlening bleek - maar van opportuniteit ${ }^{21}$, en welke rechtgeaarde partiigenoot zou nú nog twiffelen over de geschiktheid van tijd of gelegenheid?

Ruys' instemming met het vrouwenkiesrecht is dan ook geen concessie aan degene die "langs illegale weg verbeteringen wil aanbrengen", maar is een aansporing voor de kamer om op de reeds eerdler - op initiatief van Marchant - ingeslagen weg onverlet voort te gaan. Een respectabel politiek gebaar van de premier, is men geneigd te zeggen, maar straks blijkt dat een deel van zijn ministersploeg en de ware aanhangers van het huismanskiesrecht daar bepaald anders over denken !

\section{* Vreugde over de goede afloop}

Zondagmiddag 17 november blaast het congres van de SDAP en het NWV de revolutieplannen af. "Als eerlijk man gevoel ik mij verplicht te zeggen, dat ik de machtsverhoudingen niet geheel juist gezien heb.", moet Troelstra erkennen. ${ }^{22}$

De revolutlepoging, zo kan men vaststellen, ontbrak het aan een scherpe analyse van de situatie in Nederland, aan koel beraad, aan een uitgekiende tactiek, aan know-how bovendien, maar ... wat hebben volgelingen van Karl Marx nou helemaal aan een leermeester die een bij hem naar een strijdplan voor revolutie hengelende Domela Nieuwenhuis ooit te verstaan gaf: "Je moet niet van die domme vragen stellen, Ferdinand." ? ${ }^{23}$

Een dag later is het Malieveld in Den Haag het feestterrein waar de enorme vreugde over de goede afloop van de enerverende week uitbarst in een massale aanhankelijkheidsbetuiging aan de koninklijke familie. Enthouslast gejuich is er ook voor de ministers die de vorstelijke stoet vergezellen. Nog zeven andere steden bewijzen de koningin in de rest van de maand uitbundige hulde.

Gaandeweg rijst echter ook kritiek op haar tournee door het land: is men 
niet bezig het staatshoofd te verlagen tot een argeloze propagandiste voor rechts? 24

Nog vóór de kamerdebatten over de novembergebeurtenissen zijn afgelopen verschijnt op 20 november in een speciale editie van de Staatscourant een proclamatie van de koningin aan de Nederlandse bevolking. Al een week eerder wilde Wilhelmina een woord tot de natie richten, maar het kabinet kon haar er toen - met enige moeite - van overtuigen dat zo"n plan in het heetst van de strijd niet opportuun zou zijn. Nu de regering de precaire situatie inmiddels in bedwang heeft, hoeft de boodschap aan mijn volk niet langer te wachten: "Ik voel Mij gedrongen, na hetgeen wil in de bange oorlogsjaren en in de laatste dagen met elkander hebben doorleefd, een woord tot $\mathrm{U}$, Mijn Volk, te spreken... Ik breng Mijnen hartelijken dank aan de mannen van leger en vloot ... en niet minder aan $U$ allen, mannen en vrouwen, die met geduld en volharding de ontbering, door den krijg veroorzaakt, hebt gedragen ... Het grondwettig gewaarborgd recht van het Volk om langs wettigen weg, niet onder den druk van drejgement, zijn verlangen over zijn lot te doen kennen, is gehandhaafd en het parlementair overleg kan worden voortgezet. Het is Mijn verlangen de voorgenomen hervormingen door te zetten en aan te vullen met de snelheid, die past bij den polsslag van dezen tijd ... Ik heb verstaan, dat Gij Mij daarin steunt en met liefde en vertrouwen tegemoet treedt ..." 25

Placht een regerend vorst zich naar de trant van toen tot de burgers te richten in termen van mijn volk of onderdanen, in de proclamatie van de koningin is nu echter óók een duidelijk wijgevoe/ aanwezig. Naast de nog minzame majesteitelijke deernis over de verschrikkingen die het volk heeft moeten verduren van de oorlog en de eerste "vredesweek", beluistert men in haar woorden ook grote vreugde over de gezamenlijk overwonnen beproevingen, en is haar diepe dank voor de overweldigende steun die zij als antwoord op de aanval op de Kroon mocht ontvangen, net zo min afstandelijk te noemen. Is het vreemd dat in deze sfeer van koninklijke solidariteit met de bevolking de proclamatie een ongewoon nadrukkelijke politieke lading - overigens gedekt door ministerieel contraseign - heeft ? De regering heeft de revolutiepoging van Troelstra weerstaan. De toestand is weer rustig. De tijd voor hervormingen is aangebroken. De heren van het kabinet willen snel vooruit; na zoveel beroering is terugkrabbelen er niet meer bij! 


\subsection{Het kabinetsdebuut in het licht van het staatsrecht}

In diverse opzichten zijn de eerste drie maanden van het kabinet-Ruys ook uit een oogpunt van staatsrecht belangwekkend. We noemen in dit verband de accentuering van het ambt van eerste minister, de verhouding tussen het staatshoofd en de ministers, alsmede de revolutiepoging van Troelstra.

Terloops kwam reeds ter sprake dat Ruys zich meteen na zijn aantreden voorzag van wettelijke ruggensteun voor zijn coördinerende taak als voorzitter van de ministerraad. In hoeverre het desbetreffende koninklijk besluit van invloed is op de betrekkingen tussen de ministers, behoeft enige nadere uitdieping. Voorts speelt de vraag of het ministeriële kordon rond de koningin gedurende de hectische novembermaand steeds hecht genoeg was om de toets aan het staatsrecht te doorstaan. En waar er de regering alles aan gelegen was "de grondslagen van ons maatschappelijk en politiek leven te beschermen", is er, ten slotte, een goede reden ook even stil te staan bij het werk dat zij ervan maakt om gevaar voor een onverhoedse aanval op het staatsbestel in te dammen.

\section{* Versterking van het premierschap}

Het premierschap heeft in de loop van de jaren een ontwikkeling doorgemaakt dle het ambt deed uitgroeien van een primus inter pares tot een meer en meer geprofileerd minister-presidentschap.

Voor de regeling van het voorzitterschap van de ministerraad zijn speciaal de jaren 1901, 1905, 1918, 1922, 1945 en 1983 van belang. Gold vóór 1901 het systeem van verkiezing van de voorzitter, de wijziging van het reglement van orde voor de raad van ministers stelde daar in 1901 benoeming door de Kroon voor in de plaats. De nieuwe regeling kwam tegemoet aan het streven van Kuyper om zich een bijzondere positie als minister-president te verwerven. Na het aftreden van het kabinet-Kuyper In 1905 ging men weer over op het oude systeem, zi] het dat vanaf 1922 de voorzitter niet meer tijdelijk heette te zljn. En zó is het gebleven tot 1945, toen de eerste naoorlogse premier, Ir. W. Schermerhorn, in het reglement liet vastleggen dat de voorzitter voor de duur van zijn mandaat door de Kroon wordt benoemd en de titel van minister-president draagt. Een met die van 1945 vergelijkbare regeling is in 1983 ook in de grondwet opgenomen. Met de inwerkingtreding van de bepaling dat de - door de Kroon te benoemen - "minister-president" voorzitter is van de "ministerraad" (artikel 45, lid 2) krijgen twee organen die "zich duidellik als zelfstandige grootheden [hebben] gemanifesteerd" ${ }^{26}$ voor het eerst grond- 
wettelijke status. In aangelegenheden van algemeen regeringsbeleid heeft de samenbindende rol van beide organen - zoals blijkt uit voornoemd artikel 45 , leden $1 \mathrm{t} / \mathrm{m} \mathrm{3}$, nader uitgewerkt in het reglement van orde voor de raad van ministers - aan belang gewonnen ten koste van het zelfstandige element in de functie van de afzonderlijke ministers.

Al staan beide organen thans meer op de voorgrond, hun coördinerende rol heeft in hoofdzaak slechts betekenis voor de interne werking van het samenspel van de ministers, en laat de individuele verantwoordelijkheid van de ministers jegens beide kamers van de Staten-Generaal onverlet. Tegen die achtergrond prevaleert nog steeds het collegiale karakter van de functie van minister-president, heeft hij niet de dominerende rol van een Britse prime minister of een Duitse Bundeskanzler en is zijn positle naar buiten toe niet uitgesproken versterkt, aangenomen dat staatsrechtelijke leer en praktijk altijd zouden samenvallen. ${ }^{27}$

Bezien we nu het koninklijk besluit van 13 september 1918, $\mathrm{nr}$. 38. Deze wettelijke maatregel - na een solitair bestaan, in 1956 geïncomoreerd in het reglement van orde voor de raad van ministers - verplicht een minister niet eerder een beslissing te nemen over zaken waarbij het algemeen regeringsbeleid kàn zijn betrokken, dan na overleg met de minister-president. De aldus beperkte bevoegdheid van de ministers gaat samen met een toenemende coördinerende rol van de voorzitter van de ministerraad èn van de raad zelf, want de kwestie moet worden voorgelegd aan het collectief als primus en pares het met elkaar niet eens kunnen worden. In het licht van de grondwetswijziging van $1983 \mathrm{kan}$ men in het KB van 19.18 niets anders zien dan een puur interne uitbreiding van het huishoudelijke reglement van de ministerraad, maar het is wèl een besluit dat de ministers bindt en - meer speciaal - de positie van de premier ten opzichte van zijn collega's versterkt.

Zonder er de ministerraad vooraf in te kennen, betuigde Ruys op 13 november in de kamer zijn instemming met de invoering van het vrouwenkiesrecht. ${ }^{28}$ Vergeefs zoekt men, zoals uit het voorafgaande moge biliken, voor dit eigenmachtige optreden van de premier een aanknopingspunt in het huishoudelijke reglement van de ministerraad. "Dat is de eenige fout, die deze week door ons gemaakt is ..." 29 , verwijt de zich gepasseerd voelende Aalberse de kabinetsleider. Heemskerk daarentegen vindt die "polltieke zet" van Ruys in de gegeven abnormale omstandigheden alleszins verstandig.

Naar deze uitlating te oordelen, is de minister van justitie geen authentieke spreekbuis van zijn achterban. Het antirevolutionaire staatsbegrip van die dagen verzet zich namelijk uit beginsel tegen algemeen klesrecht, om- 
dat de individualistische grondslag daarvan geen recht doet aan het gezin als organische kern van het maatschappelijke samenstel. Het is het gezinshoofd - de huisman - dat het exclusieve stemrecht toekomt, is de achtergrond van de kritiek die Ruys met zijn verklaring over het vrouwenkiesrecht van collega Idenburg te horen krijgt.

Bij de Tweede-Kamerbehandeling van het initiatiefvoorstel-Marchant klinkt dit principlële geluild uit orthodox-protestantse hoek opnieuw op, zonder overigens weerklank te vinden bij de overgrote meerderheid van de kamer.

\section{* De koninklitke onschendbaarheid}

De regering wordt gevormd door de koning en de ministers. Deze tweeeenheid in aangelegenheden van regeringsbeleid komt onder meer tot ulting in de gezamenlijke ondertekening van alle koninklijke besluiten, beschikkingen en - sinds 1983 ook - van wetten door het staatshoofd en een of meer ministers of staatssecretarissen.

Dit zogenaamde contraseign van een bewindspersoon is een uitvloeisel van de in 1848 ingevoerde koninklijke onschendbaarheid, gepaard gaande met de politieke ministeriële verantwoordelijkheid voor het totale regeringsbeleid. Alleen de ministers zijn aanspreekbaar voor het optreden van de regering en trouwens ook voor het doen en laten van de koning en het koninklijk huis. Het aandeel van de koning in het regeringsbeleid staat echter krachtens zijn grondwettelijke onschendbaarheid buiten de politieke discussie, zelfs als het staatshoofd of een van ziljn ministers naar buiten zou laten blijken van het Grote Staatsgeheim.

Onmiskenbaar zijn de constitutionele spelregels bij de proclamatie van de koningin op 20 november formeel juist toegepast. Door de koninklijke boodschap te contraseigneren namen de ministers deze immers geheel voor hun rekening. Maar het kabinet deed er niet echt verstandig aan de proclamatie te laten verschijnen op een moment dat de kamerdebatten over de novembergebeurtenissen in volle gang waren en de politiek beladen woorden van Wilhelmina best nog aanleiding konden geven tot kritiek die ook haar niet zou sparen.

Ook in de regie van de feestelijke novembermanifestaties toonde het kabinet zich niet een bijzonder prudent handhaver van de monarchie. Het liet de koningin tljdens haar tournee door het land zó openlijk en scherp in het zoeklicht komen dat haar persoon gevaar liep in de partijpolitiek te worden gemengd. Dat "neutraal" kamerlid $\mathrm{mr}$. $M$. Treub het kabinet onderschatting van dat risico verweet, is beslist niet misplaatst, doch de konin- 
gin daarbij meteen ook maar een - zij het onbewuste - propagandiste voor de ... rooms-katholieke partij noemen ${ }^{30}$, klinkt wel erg kolderiek.

Is er wel een excuus voor dat het kabinet de spelregels voor de relatie koning-ministers in de uitzonderlijke novembermaand van 1918 een beetje ongewoon toepaste, wat Ruys vier jaar later bij de grondwettelijke herziening van het inkomen van de koning doet, kan moeilijk anders dan een geheide constitutionele misser heten. Voor zijn afwiljzing van een amendement op het regeringsvoorstel tot verhoging van de jaarlijkse uitkering aan het staatshoofd beroept de premier zich op een verklaring van de koningin, waarin zij zich voorneemt heel zuinig met het extra bedrag om te gaan en een eventueel restant in de staatskas terug te storten. Ten onrechte betrekt de premier hier de koningin in het politieke debat over de vaststelling van haar inkomen. Zonder ministerieel verantwoordelijk te ziljn voor de wijze waarop Wilhelmina haar inkomen in alle vrijheld denkt te besteden, gebruikt Ruys niettemin haar verklaring dienaangaande als een argument om het regeringsvoorstel onverkort te handhaven. ${ }^{31}$

Door resoluut op te treden behoedde het kabinet de monarchie in de revolutieweek voor de ondergang, maar het maakte vervolgens wel enkele foutjes die duiden op een wat lichtvaardig besef van zijn ministeriële verantwoordelijkheid.

Het ministeriële kordon rond de koningin in 1918 - en zeker in 1922 - is per slot dan ook geen toonbeeld van hechtheid, al is het waar dat een sterke persoonlijkheid als de Onschendbare zich niet gemakkelijk laat afschermen.

\section{* Constitutie en revolutie}

Revolutie en staatsgrepen zijn niet vreemd geweest aan onze staatsregelingen uit de Franse tijd (1795-1813). De fluwelen revolutle van 1795 maakte van de Republiek der Verenigde Nederlanden een vazalstaat van Frankrijk, waarna dit land - aanvankelijk als een achtergrondregisseur van een reeks staatsgrepen, later als een openlijke baas in andermans huis hier de constituties telkens naar de laatste mode in Parljs onder handlen nam. Desondanks zijn er ook nu nog verlate patriotten die de Bataafse grondwet van 1798 als hèt handvest van onze parlementaire democratie beschouwen.

Op het keerpunt van de politieke geschiedenis in 1813 volgt ons staatsrecht een weg die zich zigzag baant door het nieuwe van de geïmporteerde Franse revolutie en de gedachtewereld van het stadhouderlijke tijdperk van vóór $1795 .{ }^{32}$ Wars van het beginsel van de volkssoevereiniteit, 
dat met al ziln schilnwertoningen in de praktijk was ultgelopen op "de heerschappli van eén Caesar", geeft men in de grondwet van 1814 de aanzet tot een stelsel waarin de staatsmachten elkaar door onderlinge beirvoeding in balans moeten houden.

Naast deze voorloper van het stelsel van checks and balances vormt ook een in dat laar ingevoerde - en in 1848 herziene en sindsdien nagenoeg onveranderde - procedure voor grondwetsherzlening een tegenwicht tegen llchtvaardige awntasting van de hoofdregels van het staatsbestel. Deze herzleningsprocedure, die thans voorkomt in artikel 137 van de grondwet, is een omslachtige en zware uitvoering in twee bedrijven, waarin eerst de zittende Staten-Generaal en vervolgens het nieuwe parlement oordelen over de whziging, zonder dat de kezers daar tussentijds of achteraf een directe uitspraak over kunnen doen.

Naarmate men herzlening van de grondwet minder gemakkelik maakt, wordt het gevaar groter, aldus Oud ${ }^{33}$, dat in tijden van spanning wijziging langs revolutionaire weg zal worden beproefd. Dit blikt in 1918. Het " ${ }^{*} .$. langzame gesukkel van het parlementaire stelsel belet de nieuwe klasse ... te doen wat de omstandigheden eischen, en ... dan moet er nu een andere methode, die van revolutie, worden gebezigd ...", zegt Troelstra. En is het niet Karl Marx die hem voorhoudt dat de onderdrukte klasse aan haar doeleinden, cle samenvallen met de hogere doeleinden van de mensheid, hat recht ontleent tot geweld, dictatuur en omverwerping van de oude orde? ${ }^{34}$

Lichtvaardige aantasting van de hoofdregels van het statatsbestel, langzaam gesukkel van het parlementaire stelsel, hogere doeleinden van de mensheld: inderdaad, de regering en het parlement hebben thans beweegredenen te over om grote democratische hervormingen zowel op wetgevend als op soclaal gebled onmiddelitik ter hand te nemen.

Op het terrein van het noodrecht komt in deze kabinetsperiode een tweetal regelingen tot stand. De oorlogswet van 1899, die bepaalt wat er moet gebeuren als het Rijk in de noodtoestand van staat van oorlog of beleg geraakt, verruimt na haar wijziging op 22 november 1918 (Staatsblad nr. 604) de verordenende bevoegdheid van het militaire gezag: het kan van die bevoegdheid bij staat van beleg, anders dan bij staat van oorlog, voortaan zonder overleg met de burgerlijke autoriteiten gebruik maken. Daarbil wordt op 28 jull 1920 (Staatsblad nr. 619) het Wetboek van Strafrecht aangevuld met nadere voorzieningen tot bestrijding van revolutionaire woelingen: een gelegenheidswetgeving van Heemskerk, die uit staatkundig oogpunt van weinig betekenis is.

In de tussentijd bereidt een staatscommissie onder voorzitterschap van 
Ruys een herziening van de grondwet voor. Waar dat toe leidt, komt aan het eind van dit hoofdstuk aan de orde.

Er is echter geen eis van de nieuwe tijd die de politiek voorlopig zo beheerst als de sociale kwestie. We tellen hierna eens de zegeningen van zo'n unieke situatie.

\subsection{De eisen van de nieuwe tijd}

Nauwelijks staat het kabinet na de roerige novembermaand in de startblokken om het regeerprogram af te werken, of internationale repercussies van de oorlog dienen zich aan. De argwanende houding van de geallieerden tegenover het neutrale Nederland slaat bij het eind van de oorlog om in een groot ongenoegen als na de ondertekening van de wapenstilstand ons land een deel van de verslagen Duitse troepen ongewapend uit België via Limburg laat afmarcheren naar de Heimat. Als zwaar getroffen, morele overwinnaar tracht België munt te slaan uit de anti-stemming jegens zljn noorderbuur door een zware claim te leggen op Zeeuws-Vlaanderen en driekwart van Limburg. De touwtrekkerij om de herzlening van de Londense verdragen van 1839 blijft nog jarenlang de verhitte gemoederen in Noord en Zuid beheersen...

Ook het gastrecht van de ex-keizer is een steen des aanstoots voor de overwinnaars. Om alvast een duidelijke stelling te betrekken tegen het weldra te verwachten uitleveringsverzoek van de grote mogendheder, verklaart Ruys op 10 december in de Tweede Kamer dat de regering nlet wenst af te wijken van de aloude traditie van het asielrecht. Wanneer na een jaar van diplomatiek bakkeleien over de ex-keizer de Franse premier Georges Clemenceau namens de Entente officieel om Wilhelms uitlevering verzoekt, legt de regering deze affaire gewoon naast zich neer, en er is geen haan die er verder meer naar kraalit ...

\section{* Het topjaar van de sociale wetgeving}

Met een ongekend omvangrijk pakket maatregelen op het gebied van arbeidersbescherming, sociale verzekering, bedrijfsorganisatie, volkshuisvesting en volksgezondheid schetst Ruys op 10 december bij de opening van de algemene beschouwingen over de begroting van 1919 in de Tweede Kamer de contouren van een jaar zonder weerga.

Deze maatregelen, verzekert Ruys, zijn geenszins een gevolg van de gebeurtenissen en dreigementen in de week van 11 november, maar vloeien voort uit: "... Zijn [Aalberses] werkplan [en stonden] voor hem vast, vóór- 
dat hij de ministeriële portefeuille aanvaardde..." 35

Ter uitvoering van haar program wil de regering, aldus de premier, thans zo spoedig mogelijk Talma's arbeldswet 1911 en wet op de Raden van Arbeid 1913 uitbreiden en diens - in 1913 in het Staatsblad verschenen, maar nog niet inwerkinggetreden - invaliditeitswet en ziektewet in gewijzigde vorm invoeren. Voorts staan een ingrijpende herziening van de ongevallenwet 1901, alsmede een vrijwillige ouderdomsverzekering, een ongevallenverzekering van zeelieden en tal van voorzleningen op het terrein van de woningbouw en de volksgezondheid op stapel. Van de meest verre strekking acht Ruys de voorgenomen instelling van een Hoge Raad van Arbeid, een tripartiete college dat de regering van advies moet gaan dienen over alle sociale maatregelen en als zodanig van grote betekenis kan zijn voor de bedrijfsorganisatorische hervorming van de maatschappij.

Na de kamerbrede - met uitzondering van de communisten - waardering die Ruys oogst voor het sociale program van de regering, begint de wetgevende machine van het ministerle van arbeid op volle toeren te draaien. In razend ternpo bedelft Aalberse het parlement onder wetsontwerpen.

Het eerste van de grote drie, het ontwerp-arbeidswet, wordt reeds op 11 april 1919 - anderhalve maand na de goedkeuring van de begroting van het ministerie door de Tweede Kamer - bij de kamer ingediend, op 20 juni gevolgd door het ontwerp tot wijziging van de invaliditeitswet èn het ontwerp tot regeling van de vrijwillige ouderdomsverzekering.

De wetsvoorstellen gaan er ongewoon snel door. Drie maanden na de indiening van de ontwerpen, passeren deze reeds de Tweede Kamer en op 31 oktober maakt de Senaat het drievoudige succes van Aalberse compleet. "Het zal wel zelden zijn voorgekomen, dat op zo enkele dagen zoveel en zo belangrijke ontwerpen op verschillend gebied van éénzelfde departement werden aangenomen." ${ }^{36}$, schrijft secretaris-generaal mr. L.A. Scholtens met gepaste trots aan zijn minister.

Overigens bereiken in 1919 ook nog verschillende kleinere wetten, als de herziene radenwet, de zeeongevallenwet, de vleeskeuringswet, de warenwet en de wet op het Staatstoezicht der Volksgezondheid, naast de instelling van de Hoge Raad van Arbeid, het Staatsblad.

Kon minister ds. A. Talma zijn sociale verzekeringswetten in 1913 slechts met veel tegenwind het Staatsblad inloodsen, zes jaar later heeft Aalberse bij de uitbouw van het sociale verzekeringsstelsel wél het getij mee.

De ongevallenwet is aan grondige, tijdvergende revisie toe, maar een provisionele wijziging van de oudste sociale verzekeringswet van ons land zorgt ervoor dat de uitkeringen bij ongevallen binnen enkele maanden zijn 
aangepast aan de gestegen kosten van levensonderhoud.

Al op 3 december treedt de invaliditeitswet 1919 in werking, die de verplicht verzekerde arbeider in loondienst recht geeft op invaliditeitsrente, waaronder begrepen een ouderdomspensioen bij het bereiken van de 65 jarige leeftijd. Anders dan in de wet van Talma komt de verzekeringspremie nu geheel voor rekening van de werkgever, gaat het pensioen niet op zeventigjarige leeftijd maar vijf jaar eerder in, en hebben naast wezen thans óók weduwen aanspraak op een renteuitkering.

In samenhang met de verplichte ouderdomsverzekering van de arbeider wil het ontwerp-ouderdomswet voor alle Nederlanders en rijksingezetenen de mogelijkheid openen op vrijwillige basis bij de overheid een pensioenverzekering af te sluiten. Voordat ook deze wet op 3 december in werking treedt, moet Aalberse in de Tweede Kamer eerst nog enige amendementen die de verzekerde beogen te ontheffen van de premielast, tot een "... voor mij onaannemelijk stuk staatspensionering ..." verklaren.

We komen nu toe aan de arbeidswet 1919, het onbetwiste chef d'oeuvre van Aalberse. Behalve dat de nieuwe wet een aanscherping bevat van de bepalingen die reeds golden voor het verbod van kinderarbeld en de bescherming van jeugdige personen en vrouwen, strekt de werkingssfeer van het geestesproduct van de minister van arbeid zich nu ook uit tot de volwassen mannelijke arbeiders.

Was de arbeidswet van Ruys senior nog besmet met de tljdgeest van de staatsonthouding en liet de arbeidswet van Talma zich nog door economische motieven weerhouden van beperking van de arbeidsduur van de mannen, met de invoering van de 45-urige werkweek en de vrlje zaterdagmiddag in ondernemingen en hiermee gelijkgestelde irrichtingen en kantoren legt de arbeldswet van Aalberse de grondslag voor de verheffing van de sociale positie van de arbeider.

Zoals de Hoge Raad in zijn arrest van 26 oktober 1931, N.J. 1932, blz. 413, overweegt, is de strekking van deze wet: " ... niet alleen de arbeider voor overmatige vermoeidheid te behoeden, doch ook om hem de vrije beschikking over een voldoende deel van zijn tijd te geven ten behoeve van eigen ontwikkeling en ontspanning en in het belang van ziljn gezin ..." De ingreep van de overheid in de arbeidsvoorwaarden van de volwassen mannen veroorzaakt een principiële doorbraak op het gebied van de arbeidersbescherming. De veel verdergaande strekking van de arbeidswet 1919 doet haar fundamenteel verschillen van haar beide voorlopers. Deze wet, die "een der zegenrijkste wetten [zal] blijken te $z i j n$ " ${ }^{37}$, bezorgt Aalberse de onuitwisbare reputatie van sociale hervormer én van ... taaie volhouder. Want moest hij tien jaar geleden - toen hij met zijn mede namens 
Ruys ingediende motie Talma vergeefs trachtte te bewegen de arbeidsduur voor volwassen arbeiders tot tien uur per dag te beperken - ervaren dat je zolets nlet kunt forceren, nú bieden de eisen van de nieuwe tijd hem de kans om zijn werk van de lange adem te voltooien. "Aalberse was nog royaler", herinnert socialistisch kamerlid J. Schaper zich, "dan wij: stelde ik voor een 46-urige, hij een 45-urige werkweek ..." 38

Even loopt Nederland internationaal voorop met zljn 45-urige werkweek, maar binnen drie jaar raakt het zijn voorsprong weer kwijt als een resolutie van de eerste Internationale Arbeidsconferentie van oktober 1919 in Washington Aalberse met klem uitnodigt de aldaar aanvaarde 48-urige werkweek eveneens in het g/dsland bij wet in te voeren.

Aan het eind van 1919 toont de staat van actief op de balans van het ministerie van arbeid een indrukwekkend resultaat op het gebied van de sociale wetgeving en de volkshuisvesting. Ook in de komende regeerperiode blijt Aalberse met onvermoeide viljt liveren voor de hervorming van het soclale stelsel, de woningbouw en de woningverbetering. ${ }^{39}$

Zo krijgt in 1921 de grondige herzlening van de ongevallenwet 1901 haar beslag. De wijziging van de oude wet is dermate drastisch dat men haar voortaan de industriële ongevallenwet 1921 noemt.

Vervolgens verschijnt in 1922 een speciale ongevallenverzekering voor de werknemers in de agrarische sector en de bosbouw. Deze land- en tuinbouwongevallenwet is de eerste sociale verzekeringswet met een duaal uitvoeringsstelsel. Het alleenrecht van een rijksorgaan op centrale uitvoering van de sociale verzekering moet wijken voor een uitvoeringsorganisatie waarin men voor deze verzekering óók terecht kan bij een bedrijfsvereniging. Na een jarenlange parlementaire strijd over de grondslag van het uitvoeringsstelsel, waait de wind nu uit een andere hoek.

De inschakeling van bedrijfsverenigingen is na de instelling van de Hoge Raad van Arbeid een volgende stap in de richting van de bedrijfsorganisatorische vernieuwing van de maatschappij.

De genoemde wet van 1922 komt in die zin tegemoet aan de in christendemocratische hoek gekoesterde gedachte aan een maatschappelijk middenveld met eigen taken en bevoegdheden in het sockal-economische bestel. Dit denkbeeld vindt men onder meer terug bij de aanhangers van Kuypers soevereiniteit in eigen kring ${ }^{40}$, volgens welke leer maatschappelijke organisaties en bedrijfslichamen zelfstandig gezag toekomt dat door de overheid moet worden gerespecteerd.

Daarnaast gaat de katholieke school uit van een organische staatsopvatting die de staatsbemoeiing in de vorm van sociale wetgeving will combineren met een ordening van de samenleving op de grondslag van part- 
cipatie en zeggenschap van het georganiseerde beroeps- en bedrijfsleven. De zelfwerkzaamheid van de "lagere organen" vormt de kerngedachte van dit zogenaamde subsidiariteitsbeginsel. En Aalberse neemt dat tot richtsnoer als hij de nleuwe sociale wetgeving voorzlet van prikkels die de indvidualistische samenleving moeten veranderen in een sociaal bouwwerk, gegrondvest op een brede organisatie van arbeiders en middenstanders.

Het kabinet heeft in Aalberse en Ruys excellente volgelingen van de katholieke school. Beiden zijn pioniers van de katholieke sociale actie, werken in de geest van Rerum Novarum - aan een nieuwe inrichting van de maatschappij, geven de stoot tot de oprichting van vakorganisaties en verenigingen op velerlei terreinen en begunstigen met deze zullen de emancipatie van met name de onderste lagen van de samenleving.

De twee voormannen gaan daarbij op geheel eigen wijze te werk. Aalberse, de uit de lagere middenstand voortgekomen hoogvlieger, is vooral de man van wetenschap en wetgeving. Ruys, de edelman in wle "wel zeer duidelijk gedemonstreerd wordt, hoeveel natuurlijker de adel tot begrip en waardering van de sociale actie kwam dan de bourgeoisie" ${ }^{41}$, is meer de doener, met een waaier van bestuursfuncties in het maatschappelijke en culturele vlak op nationaal niveau.

Aalberse is er niet in geslaagd de herziening van de ziektewet voor elkaar te brengen. Notabene met de Hoge Raad van Arbeid - zinn schepping, die ministerie en maatschappij nader tot elkaar zou moeten brengen - krljgt hij het aan de stok over de organisatie van de uitvoering van de wet. We zijn drie kabinetten verder als het minister Slotemaker de Bruïne lukt een moeizaam, dualistisch compromis te bereiken met de Raad, en vervolgens is het nog wachten op het derde kabinet-Ruys voordat minister Verschuur de ziektewet 1930 eindelijk kan invoeren... De drive van het topjaar 1919 is dan alweer lang voorbij !

\section{* Actief vrouwenklesrecht}

Het vrouwenkiesrecht is in ons land bepaald niet uit een spontane opwelling voortgekomen. Als de regering de Tweede Kamer in 1915 voorstelt over te gaan tot invoering van het evenredigheidsstelsel, het algemeen mannenkiesrecht, de verkiesbaarheid van vrouwen en opheffing van de grondwettelijke uitsluiting van vrouwenkjesrecht, moet er een uitruil met een nieuw onderwijsartikel 192 aan te pas komen eer deze baanbrekende kiesrechtbepalingen van de grondwet de eindstreep halen. "De openbare school ingeruild ter wille van het algemeen kiesrecht", sneert de bekende cartoonist Johan Braakensiek in zijn spotprent aan het adres van 
de vrijzinnigen en de socialisten: net alsof $z i \hat{j}$ alleen concessies hadden moeten doen, net alsof nu trouwens ook vrouwen konden gaan stemmen...

Nu de grondwet het de gewone wetgever sinds 1917 niet langer onmogelijk maakte het vrouwenklesrecht in te voeren, leefde in het de vrouwenbeweging toegedane politieke kamp de verwachting dat de regering die stille wenk van de hoogste wetgever meteen zou opvolgen. De troonrede van 1918 zwigt daar evenwel in alle toonaarden over. En als de fracties van de vrijzinnig-democraten (VDB) en de SDAP in de Eerste Kamer Ruys vragen wat die grote stilte te betekenen heeft, verklaart de premier dat van het kabinet geen voorstel tot invoering van het vrouwenkiesrecht te verwachten is. Dat is van later zorg, laat hij in zijn antwoord doorschemeren, en prompt komt daarop de Tweede Kamer in 't geweer: in september dient de vrijzinnig-democraat Marchant een initiatief-voorstel in dat vrouwen en mannen voor de kieswet gelijk beoogt te behandelen. Acht maanden later buigt het parlement zich over zijn eigen initiatief. De tijd had intussen niet stilgestaan.

Het was de overwinning van het gezonde verstand toen de wig die de slepende politieke strijdvragen in ons volksleven had geslagen, er in 1917 werd uitgehaald. ${ }^{42}$

Toch hield dit historische vergelijk geen belofte in voor het welslagen van het initlatief waarmee Marchant een jaar later de kiesrechthervorming tracht te completeren. Het klimaat voor invoering van het vrouwenklesrecht is in september 1918 niet onverdeeld gunstig: in de regeringsfracties hebben principieel verzet aan protestantse zljde en opportuniteitsbezwaren aan katholieke kant nog de overhand, en ook in de gelederen van de vrij- en unie-liberalen voeren de voorstanders van uitbreiding van het kiesrecht zeker niet de boventoon.

Maar de novembergebeurtenissen missen hun uitwerking niet. Het is hoog tijd om vaart achter grote democratische en sociale hervormingen te zetten, en het is de stem van Ruys, die daar als eerste toe oproept. Meer realo dan fundo in de kwestie van het vrouwenkiesrecht geeft hij in zijn regeringsverklaring van 13 november een signaal af dat Nolens, Lohman en andere politicl met werkelljkheidszin helder opvangen en verstaan.

Na Ruys' gezaghebbende interventie ontmoet Marchant acht maanden later weinig weerstand bil de verdediging van zijn ontwerp in de beide kamers. Het initiatiefvoorstel krijgt nu ook de steun van alle katholieken, liberalen en de meeste christelijk-historischen, en zo verzekert Nederland zich in 1919 van een - bescheiden - negende plaats in het klassement van landen waar vrouwen mogen stemmen. 
Aan Gioacchino Rossini's una voce poco fa hoeft beslist niets te veranderen, maar Oud heeft gelijk als hij schrijft dat Marchant heel wat minder kans van slagen zou hebben gehad als niet Ruys' stem juist véél had uitgemaakt. ${ }^{43}$

"Aan goeden wil tegenover $u$ en de uwen zal 't mil niet ontbreken" ${ }^{44}$, was Ruys' erkentelijke reactie op de gelukwens die hij bij zijn aantreden van Marchant ontving. Getrouw aan die toezegging draagt de premier er nadien zijn steentje toe bij dat de Vereeniging voor Vrouwenkiesrecht van Wilhelmina Drucker en Aletta Jacobs haar zilveren ... bestaan in feeststemming kan vieren.

\section{* Schoolwet-De Visser}

"Mijn vader heeft veel verdriet van de onderwijskwestie gehad. Hij heeft het altijd zeer betreurd, dat hij verplicht geweest was, de hatelijke onderwijswet-Kappeyne te ondertekenen" ${ }^{45}$, zou de koningin De Visser op de dag van zijn beëdiging hebben toevertrouwd.

Op deze gestaalde staatsman-theoloog rust nu de taak voorgoed af te rekenen met het hartzeer van 1878 door aan het in de nieuwe grondwet verankercle pacificatiebeginsel uitvoering te geven. Zijn ontwerp van de lager-onderwijswet van 1920 voorziet er in dat de centrale c.q. gemeentelijke overheid de kosten van salarissen, gebouwen en leemiddelen naar dezelfde maatstaf als voor de openbare school geldt, vergoedt aan de bijzondere school met de vereiste bezettingsgraad.

De minister krijgt bij zijn kundige verdediging van het wetsvoorstel weinig principieel verzet in de Tweede Kamer. Heel even is "de geest van onderling vertrouwen, die de [grondwets-]herzlening heeft gekenmerkt", echter volkomen zoek als na een kamermeerderheid voor een amendement dat een eind maakt aan het ambulantisme op de openbare school, de vrijzinnig-democraat Th.M. Ketelaar alsnog bij wet geregeld wil zien dat óók het hoofd van de bijzondere school voor de klas hoort te staan.

In een flits zit de kat in de gordijnen. De vrijheid van Inrichting van de blzondere school staat op het spel, en tegen de vereende kracht van rechts legt het amendement-Ketelaar met 40 tegen 28 stemmen - er is kennelijk ook enig ambulantisme bij de kamerleden - het loodje.

Met slechts drie stemmen tegen aanvaardt de Tweede Kamer in junt 1920 het ontwerp, dat vervolgens na het zomerreces zonder hoofdelijke stemming de Eerste Kamer passeert en op 9 oktober door de koningin wordt bekrachtigd.

De schoolwet bezorgt De Visser grote faam. "Zelden is een ontwerp op zo 
voortreffelilke wilze verdedigd als deze schoolwet. ... Hij heeft gedaan, wat hij kon, om op het ontwerp den stempel te drukken niet van een partijwet, maar van een nationale wet." ${ }^{46}$, steekt Oud ais "de geschiedschrifver van links" de loftrompet over deze minister.

Midzomer 1920, als de parlementaire behandeling van het ontwerp nog maar halverwege is, verneemt onze gezant bij het Vaticaan van zilin trouwe penvriend uit Den Haag dat De Visser zijn wet briljant verdedigt. "Dit korte oordeel, afkomstig van lemand die als geen ander achter de schermen zag [Puchinger heeft het over Ruys], zegt voldoende aangaande De Vlssers prestatie." 47

De geschiedenis van de wording van de schoolwet 1920 mag niet worden afgesloten zonder nog even stil te staan bij een belangrijk inhoudelijk aspect van de wet.

Volgens bij de wet te stellen regels laat de grondwet afwijking toe van de bepaling dat in elke gemeente van overheidswege in een genoegzaam aantal scholen voldoende openbaar algemeen vormend lager onderwijs wordt gegeven, mits tot het ontvangen van zodanig onderwijs gelegenheid wordt gegeven. Ter uitwerking van het grondwettelijke mits bepaalt het wetsvoorstel dat een gemeente zonder openbare school moet opdraalen voor de extra kosten ingeval een kind niet binnen een straal van $4 \mathrm{~km}$ van zljn woning in een andere gemeente naar de openbare school kan gaan.

Het ontwerp verklaart die regeling meteen ook maar van toepassing op kinderen voor wie de bijzondere school van de gewenste richting op de bezwaarlijk geachte afstand ligt.

Drukt De Visser hier niet tòch terloops de stempel van een partijwet op zijn ontwerp ? Een amendement van de communist Van Ravesteijn is daar zeer stellig in, en ook Lohman, de voormalige vice-voorzitter van de commissie voor de onderwijspacificatie, wil niet zonder meer als juist aanvaarden dat die ultbreiding past in het systeem van de grondwet.

In zijn weerwoord geeft de minister aan dat hij zich niet alleen bij de financiële gelijkstelling van de bijzondere met de openbare school, maar ook bij de daarmee annexe, onderhavige vergoedingsregeling laat leiden door het beginsel van gelijke behandeling. Met de grootst mogelijke meerderheid verwerpt de kamer daarop het amendement.

Ongetwijfeld heeft De Visser in deze kwestle het staatsrechtelijke gelijk aan zijn zijde. De herziening van het eerste lid van artikel 192 van de grondwet in 1917 maakt immers óók het bijzonder onderwils tot "een voorwerp van de aanhoudende zorg der Regering". Onverminderd de waarborgen en beperkingen die hun basis hebben in 192, geldt voortaan bil overheidsbemoeilngen met het onderwijs dan ook het in artikel 4 (oud) 
van de grondwet verankerde recht op gelijke behandeling van beide soorten onderwijs.

Waar de vergoedingsregeling voor vervangend openbaar onderwijs rust op het vierde lid van artikel 192, daar komt het eerste lid van artikel 4 te hulp om een anders ongelijke behandeling van een voor bijzonder onderwijs opterende burger gelijk te trekken.

Lohman had aanvankelijk zo zijn twijfels over het wetsontwerp. Zag hij even over het hoofd dat artikel 4 zich ook tot de wetgever richt ?

\subsection{Het kabinet in de problemen}

De tussenstand na twee jaar regeren geeft aan dat het kabinet aardig op koers ligt. De uitbouw van het sociale stelsel vordert gestaag, de schodkwestie behoort - althans vooriopig - tot het verleden, en vooraf hebben Ruys en zijn mannen ook nog zolets als een revolutie de kop ingedrukt en de orde hersteld.

Ondertussen is een machtig beschermheer almaar druk doende z/in geesteskind flankdekking te geven. Nu eens als een parlementair coryfee in het kamerdebat, dan weer als een alert souffleur achter de coulissen van de regeringstafel, werpt de onbetwiste leider van de katholieke kamerfractie zijn volle politieke gewicht in de schaal van het kabinetsbeleid.

Komt het aan op het fijnere staatkundige vakwerk, dan neemt hij de finesses van de zaak nog eens grondig door met de man die het oolt een voor-: recht noemde "onder Uw leiding mij op het politieke pad te wagen." 48 In die gevallen is voor de twee geboren Limburgers, Wiel en Charel, een wandeling over de boulevard in Scheveningen het vaste ritueel en decor om - in de eigen, vertrouwde streektaal - te communiceren over de gevoelige vraagstukken van landsbelang, het wel en wee van de coalitie en het behoud van de eenheld onder de katholieken.

Het worden langlopende gesprekken tussen twee geheel verschillende naturen. Nolens:" scherpzinnig en trefzeker, meesterlijk tacticus en organisator, maar ook dominant, kortaf en gedistantieerd, is het type van de markante zakelijke leider met onmiskenbaar autocratische neigingen. Ruys: sterke wil en vasthoudend, charmant in de omgang, samenbindend en verdraagzaam, maar ook wat oppervlaklkig en grillig, voldoet welhaast het laatstgenoemde kenmerk dwingt immers tot enige restrictie - aan de profielschets van de ware manager die de boel goed bij elkaar weet te houden. ${ }^{49}$

Hoe steekt de denker-schaker bil de doener-regelaar af ! De zestiger - architect van de coalitie, gezagvoerder van het katholieke smaldeel, impo- 


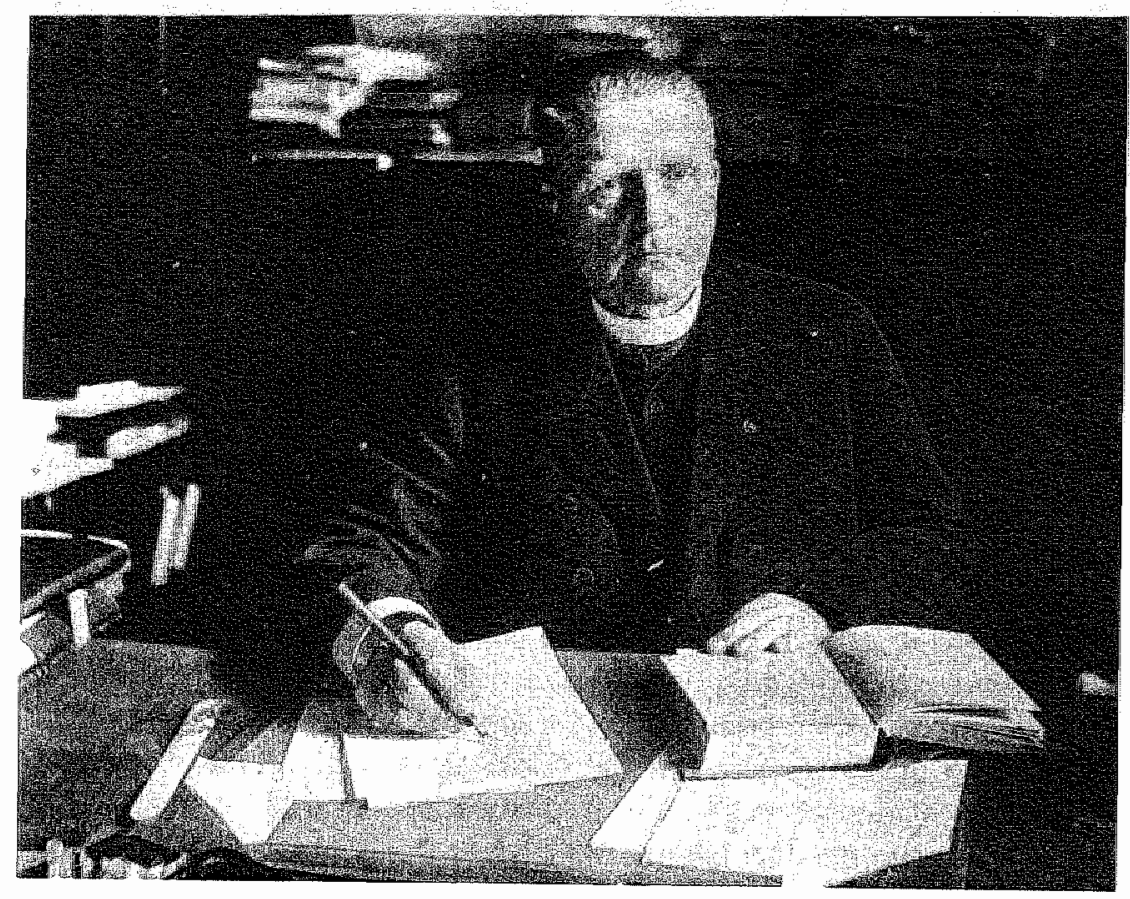

Mgr. dr. W. H. Nolens 
sant, steil, sfinxachtig en professoraal - naast de veertiger - ogenschilnlijk kleine zelfstandige in de publieke sector, frêle; onversaagd, tactvol en wiljs -: ziehier het tafereel van een tweemanschap dat te sterk contrasteert om samen een hecht koppel te vormen.

De elder statesman laat de ander volop delen in zijn kennis, inzicht en ervaring, bemoedigt, spoort aan, dringt op ... De new comer luistert, steekt op, bewondert - "zoo geleerd als diëen ben ik niet" ${ }^{50}$, zou hij volmondig kunnen toegeven -, maar blijft buiten de betovering van het gezagsaureool van de ander, en eist, enigermate eigenzinnig en koppig, zijn eigen verantwoordelijkheid op.

Beiden staan pal voor het heil van de staat, de sociale gerechtigheid en de katholieke zaak, maar in hun pact met deze belangen bieden hun uiteenlopende karakters slechts ruimte voor een zakelijke, gereserveerde verstandhouding, zonder nauwe affinitelt of intieme omgang.

$\mathrm{Na}$ een periode van wind in de zeilen krijgt het kabinet met snel aanwakkerende tegenwind te maken als in de financiële en militaire hoek grote problemen de kop opsteken. De gebruikelijke wandeling van het tegen de krachtige wind optornende duo begint te lijken op een overlevingstocht ...

\section{Pappen en nat gaan}

Het sinds 1919 voortdurend stijgende rijksuitgavenpatroon kost minister van financiën De Vries steeds heviger hoofdbrekens. De financiële nasleep van de tijdens de oorlog getroffen crisismaatregelen, maar vooral de schoksgewijze overgang van de klassieke rechtsstaat naar de sociale rechtsstaat eisen hun zware tol van de schatkist.

Is de budgettaire taak van de schatkistbewaarder in de gegeven omstandigheden bepaald niet gemakkelijk, intussen kan hij zich wel beroepen op een besluit van de ministerraad van 1919, dat zijn bevoegdheden aanmerkelijk verruimt. Voortaan moet immers elk wetsvoorstel van een collega-minister eerst de minister van financiën ter beoordeling passeren, terwijl elke wijziging in een wetsontwerp, elke toezegging aan de kamers en elke andere maatregel die belangrijke financiële gevolgen kan hebben. zijn goedkeuring - of anders die van de ministerraad - nodig heeft.

In 1919 moeten diverse directe belastingen omhoog om de begroting voor dat jaar sluitend te maken. De hoge belastingopbrengsten zorgen aanvankelijk voor een lichte opleving van de financiële toestand. De Vries rekent zich een tijdje rijk aan deze meevallers, mar verkijkt zich behoorlijk op de excessief stijgende kosten. 
A gauw is het helemaal mis met de financiën. In allerill moet de minister nieuwe belastingbronnen aanboren. Als geheid tegenstander van verdere verhoging van de inkomsten- en vermogensbelasting, zoekt hil aanvankelijk alleen in een vermogensaanwasbelasting en een gedwongen lening van $f 550$ milloen de oplossing voor het wegwerken van de "in hoge mate zorgwekkende" tekorten op de begroting voor 1920 .

Net heeft De Vries de kamer zover dat zij haar bezwaren tegen de voorgestelde leningspolitiek in het belang van de schatkist inslikt, of hij trekt die vermogensaanwasbelasting tot leders verbazing weer in... Wèl houdt hij voor "slechter tijden" nog wat anders in petto.

Eind $1920 \mathrm{krijgt}$ De Vries het in de kamer zwaar te verduren met zijn voorgenomen salarismaatregelen en zijn wetsontwerp tot uitbreiding van het gemeentelijke belastinggebied. Door de portefeuillekwestie te stellen weet hij de regeringsfracties ervan te weerhouden het pensioen van ambtenaren en onderwijzers alsnog premievrij te maken en hun steun te geven aan een amendement waarmee De Geer (CHU) een noodregeling voor gemeentelijke belastingheffing wil treffen. Het toch al tanende vertrouwen in de minister takelt, ook bij rechts, verder af als hij enkele weken later onder de druk van een staking bij de posterijen wèl toegeeft in de salariskwestie.

Oók voor 1921 kampt de minister van financiën weer met een ernstig begrotingstekort. Hij vindt het nu de tijd om met zijn plannen voor "slechter tljden" voor de dag te komen. Zijn voorstel tot verhoging van de successierechten pikt de kamer nog wel, al zijn juist heel wat leden van rechts in de contramine. Heftig is echter de oppositie van rechts én links tegen een tweetal belastingen op zogeheten artikelen van algemeen gebruik: de accijnzen op sterke drank en tabak. Opnieuw moet De Vries met zijn portefeuille zwaaien om rechts in het gareel te brengen en aldus zijn accijnzen voor de ondergang te behoeden.

Als de minister vervolgens ook de grondbelasting op alle eigendommen wil optrekken, gaat het mis. Tegen het zware geschut van links en vijf rechtse dissidenten is De Vries uiteindelijk niet bestand.

Op 13 mel 1921 verwerpt de Tweede Kamer met 39 tegen 36 stemmen het fel omstreden artikel 7 van het onderhavige wetsontwerp, en kan het uittellen van deze politiek gevoelsarme en krampachtig achter de feiten aan hollende bewindsman beginnen.

\section{* Een bedroevend zootje}

In een klimaat van epidemisch antimilitarisme en defensiepolitieke halfslachtigheid wordt de partijloze luitenant-generaal W.F. Pop op 31 maart 
1920 de nieuwe minister van oorlog èn marine. Zijn dubbele portefeuille bergt een "bedroevend zootje", zoals katholiek kamerlid mr. J. Bomans het kernachtig uitdrukt, en is bovendien besmet met de hollanditis van de jaren twintig.

Uit afkeer van oorlogsgeweld dat de arbeidersklasse dienstbaar maakt aan kapitalistische belangen, voeren de partijen op marxistische grondslag harde strijd voor algehele ontwapening. In de Vrijzinnig-Democratische Bond wroet een sluipend gevoel van weerloosheid tegen vijandelijke agressie, en uit deze defaitistische gezindheid ontwikkelt zich in die partij een politiek van afbraak van het nationale defensleapparaat. Daarentegen hechten de coalitiepartijen wèl aan paraatheid van leger en vloot in Nederland en Indië, zolang de defensieuitgaven maar omlaaggaan ... ${ }^{51}$

Met het militaire apparaat is het in 1920 dan ook treurig gesteld. De landmacht is slecht geoefend en antiquarisch bewapend, de luchtmacht met haar verouderd en onbetrouwbaar materieel is vleugellam, de marine moet zich drijvende zien te houden met "opgevaren" schepen, de defensieuitgaven zijn in een jaar tijd nagenoeg gehalveerd én het moreel van leger en vloot ligt op navenant peil.

Natuurlijk is de generaal Pop van al deze feiten op de hoogte. Maar als hi] vlak na de explosieve begrotingsbehandeling van oorlog en marine in de Tweede Kamer, de ministerspost van zijn voorgangers overneemt, moeten de kruitdampen van het parlementaire gevecht eerst goed optrekken voor hij de deplorabele militaire toestand in zijn volle omvang kan overzien.

In de lijn van een tijdens de behandeling van de oorlogsbegroting 1919 door de Tweede Kamer aanvaarde motie-Bomans, wordt oorlog in 1920 beschoten én getroffen door een reeks amendementen van Marchant. Na deze bezuinigingsslag wenst minister Von Geusau de vergaand gestripte begroting niet langer voor zijn rekening te nemen en treedt op 5 januari 1920 af. Tot 31 maart doet Ruys deze functie erbij.

Nieuwe variaties op het oude thema van de kruisers spelen een hoofdrol in het drama van de marinebegrotingen voor 1919 en 1920. Ter verdedging van Indië zette het kabinet-Cort van der Linden midden in de oorlog drie kruisers, de Java, Sumatra en Celebes, op stapel. Nu echter de oorlog voorbij is en de internationale verhoudingen nog vaste vorm moeten aannemen, wil de kamer de strategische bedoelingen van destijds niet voetstoots overnemen.

Op steun van socialistische en vrijzinnig-democratische zijde hoeft minister Naudin ten Cate niet te rekenen. En als bovendien de katholieke fractie hem terugfluit omdat zij de aanschaf van drie kruisers samen met een grondige opknapbeurt van de vloot een te kostbaar streven vindt, wacht 
de bewindsman de eindbeslissing over zljn begroting niet af, maar dient op 20 februari 1919 zijn ontslag in. Ruys neemt marine waar, laat de $\mathrm{Ce}$ lebes - voorlopig ? - "varen" en krijgt dan het groene licht van de kamer voor de begroting 1919.

Bif de begrotingsbehandeling voor 1920 dringt de kamer opnieuw op bezuinigingen aan. De katholieke fractie heeft meer dan genoeg van lapmidclelen en bepleit nu een drastisch andere opzet van de marinetaak: een sterk gereduceerde vloot-nieuwe-stijl zou als hulptroep ter zee slechts een aanvillende rol mogen spelen in de kustverdediging van Nederland en zou zlch in de Indische wateren dienen te beperken tot patrouilleren en eventuele voorpostgevechten - en het zwaardere werk aan zeemachtige bondgenoten moeten overlaten!

Dit standpunt van doorgaans bevriende zijde plaatst het kabinet voor een moellijke afweging. Wat blijft er over van het nog in het begin van het jaar door Ruys in de kamer gehanteerde argument dat de kruisers hoognodig zijn voor de verdediging van Indië, als men die nu zou prijsgeven? Daar staat tegenover dat de afbouw inderdaad een hoop geld kost en dus tevens de enige begrotingspost is waar "snijden" zoden aan de dijk zet. En wie weet ? Als het erop aankomt zou de kamer de definitieve bouwstop nog wel eens een verwerpelijke kapitaalvernietiging kunnen vinden ...

Met een halfslachtig standpunt van de ministerraad in zijn achterhoofd en een contract voor levering van pantsermateriaal voor de kruisers in zijn achterzak doet de nieuwe bewindsman van marine, mr. $H$. Bijleveld (AR), een gewaagde zet: we moeten die beide oorlogsschepen maar niet afbouwen ! De minister komt hierdoor in conflict met zijn fractie, en alls de kamer bovendien de lucht krijgt van het voorbarige contract, ziet Bijleveld vervolgens zijn begroting stranden en valt op 5 januari 1920 het doek over dit kortstondige ministerschap.

Wederom is een waarnemend minister redder in nood. Nu is het Van IIsselstel|n dle de fava en Sumatra op militaire én commerciële gronden verdedigt en veilig door de Tweede Kamer loodst.

Pop komt al spoedig na zijn aantreden tot de conclusie dat hij hard moet gaan werken aan een consistent defensiebeleid, willen leger en vloot niet de eeuwige speelbal van de politiek blijven.

Aan een interdepartementale commissie vraagt hij, hem te adviseren over een nleuw vlootontwerp. Zelf bereidt hij de reorganisatie van de landmacht voor. De gedachten die hil in de kamer etaleert gaan uit van een splitsing van het leger in kern - en reservetroepen. Onder handhaving van de in Colijns militiewet van 1912 vastgestelde jaarlijkse lichting van 23.000 
man, is Pop van plan uitsluitend recruten die tot het kernleger gaan behoren middels een - verkorte - training in de kazerne volledig op te leiden, en de rest van de lichting, na een lichte oefening buiten kazerneverband, in te lijven bij de reservetroepen.

Om uiteenlopende redenen spreken de plannen een kamermeerderheid wel aan. Dat elk wat wils geldt evenwel niet voor de AR en de CHU: zil ziljn mordicus tegen de ministeriële spinsels, die naar hun inzicht niets heel laten van de landsverdediging.

Zonder de hoofdlijn van zijn plannen los te laten, maar - als gebaar aan het adres van de protestantse partijen - wél met enige, voornamelijk cosmetische, upgrading van de paraatheid van de reservetroepen, tracht Pop met zijn ontwerp-dienstplichtwet tussen de klippen door te zeilen. Bij die riskante manoeuvre verliest de ontmaskerde millitarist de dubbelzinnige steun van de soclaal- en de vrijzinnig-democraten, kan de verzaker van de defensie de AR en de $\mathrm{CHU}$ niet tot inkeer brengen en blijven alleen de staatspartij en de Vrijheidsbond - een recente samensmelting van vrij- en unie-liberalen met drie kleine neutrale fracties - de saneerder van de legertroep trouw.

Op 15 juni 1921, een maand na het echec van minister De Vries, verwerpt de kamer het ontwerp-dienstplichtwet.

In iets meer dan twee jaar zijn vijf ministers hopeloos vastgelopen. Voor het kabinet is daarmee de maat vol. Een dag later biedt het de koningin zijn ontslag aan.

\subsection{De reconstructie van 1921}

Buiten adem van "de snelheid, die past bij den polsslag van dezen tijd", is de politiek hard aan een rustpauze toe. De wijdverbreide euforie en dadendrang van de eerste naoorlogse tijd zijn intussen ingehaald door de ontnuchterende werkelijkheid van zorgwekkende begrotingstekorten, grenzeloze verdeeidheid over essentiële vraagstukken en slijtend onderling vertrouwen van de coalitiepartners.

Gestart met ruime parlementaire steun voor de ultvoering van de Talmawetten en de herziening van de schoolwet, raakte het kabinet al na een jaar in ernstige financiële, militaire én personele problemen. Hoewel niet "extraparlementair", had het geen speciale vertrouwensband met de geestverwante fracties in het parlement, en dat wreekte zich toen onderdelen van het regeerprogram met een open eind aan de orde kwamen.

Zo'n open eind was "de militaire weerkracht van ons land en van Indië", die volgens het regeringsbeleld, "zóo moet zijn als ons onafhankelijk volks- 
bestaan en het behoud van onze Koloniën vorderen."

Dáár zat rek in, die de coalitiepartijen en ... ministers bij beurten aangrepen als hun dat van pas kwam. Eerder zagen we vier opeenvolgende ministers van marine en/of oorlog door toedoen van links, doch telkens met medewerking van een aantal leden van de rechterzijde, schipbreuk lijden. Ruys, de eindverantwoordelijke redderaar, bleef echter niet lijdzaam toezien hoe het de drenkelingen verging, en de kopstukken van de rechtse partijen wilden óók best hun handen uitsteken, maar of deze broeders hem bij zijn reddingspoging ècht zouden helpen, leerde het vervolg ...

Nolens kreeg na de verkiezing van 1918 de leiding over een sterk vernieuwde kamerclub, die het hem niet altijd gemakkelijk maakte. De linkervleugel van de fractie kwam ten gevolge van de instroom van een aantal jongeren en afgevaardigden uit de arbeidersbeweging aanzienlijk versterkt uit de bus. En deze nieuwelingen bezorgden de fractieleider niet alleen een breder draagvlak voor zijn sociale politiek, maar óók een extra dosis weerbarstigheid tegen de grote slokop van defensie.

Dit laatste bleek maar al te zeer toen de kamerclub op 4 november 1919 de oorlogsbegroting van "haar" minister besprak, en de vergadering, zwaar verbolgen over de voorgenomen stijging van de uitgaven die geheel haaks stond op de motle-Bomans van vorig jaar, de staf brak over "de onvastheid van beleid, de legertoestanden en vooral over het niet doorvœren van de beloofde reorganisatie." 52

Een crisis dreigcle en in spoedberaad verkenden Ruys en Nolens hun smalle marges. Met ettelijke miljoenen minder méér, zou Von Geusau niet mogen mopperen en zouden die lastige "jongere heeren" in de fractie uiteindelijk wel door de bocht gaan, dacht het tweemanschap ... Het liep wèl even anders !

De val van de ministers van oorlog en marine - de nekslag kwam beide keren van "broederhand" - bracht het kabinet op 5 januarl 1920 in een netelige positie. De militaire barometer stond op storm en eiste uiterst "veel geconfereer, overleg en durf" van de premier.

Ruys nam oorlog er zolang bij - de duve/stoejager was óók al stand-in geweest voor de geëclipseerde Naudin ten Cate, alsmede voor Idenburg gedurende de periode van diens ziekte tot aan het noodgedwongen ontslag van deze alom gerespecteerde bewindsman op 13 november $1919^{53}$ - en ging intussen uitvoerig te rade bij Colijn.

De - toen nog - tilidelijk voorzitter van het Centraal Comité der ARP was zich, ondanks zijn verblijf in het buitenland, waar hij leiding gaf aan de BPM, sterk blijven interesseren voor en bemoeien met de Nederlandse politiek. Ruys, op zoek naar een zwaargewicht voor defensie, lukte het 
niet de oliebaron ertoe over te haien minister te worden. Colijns ambities lagen voorlopig elders, en bovendien had hij daags vóör kerstmis 1919 nog in de vergadering van het Centraal Comitê verklaard: "... In dit kabinet zitten teveel antirevolutionairen en ze hebben de moeilijkste portefeullies. Onder geen voorwaarde moet nu weer een antirevolutionair zich beschkbaar stellen." 54

Ook bij de christelijk-historischen ving de premier vervolgens bot.

Het open overleg met de AR en de CHU maakte het Ruys overigens wel duidelijk waarom zij de banden met het kabinet wat wilden vieren. Beide protestantse partijen waren namelijk fel gekant tegen verdere inkrimping van de defensleuitgaven en hadden om die reden grote moeite met de huns inziens laconieke houding die het kabinet en de katholieke fractie tegenover de landsverdediging annamen: verkeerden die laatste twee gezelschappen soms, net als links, in de waan dat voortaan de Volkenbond de internationale vrede en veiligheid zou waarborgen? Daar kwam nog bij dat de protestantse fracties ernstige budgettalre bezwaren bleken te hebben tegen de sneltreinvaart waarmee Aalberse zich op het sociale vraagstuk stortte.

Vol nieuwe defensieplannen en met het vaste voornemen gat in de hand De Vries en big spender Aalberse eens flink de waarheid te zeggen, zette de premier, alias minister van oorlog ad interim, het jaar 1920 in.

Dat was een durf die spoedig reactie opriep: "Krijg ik moeite in 't Kabinet ? Voor een week begon Ruys in den Ministerraad De Vries een standje te schoppen, dat hij niet genoeg op de financiën lette: ik gaf te veel uit, de werkloosheidsverzekering kostte schatten gelds, mijn voorstel betreffende ziekenfondsen was veel te duur ... Wanneer "t dezen kant uitgaat .... dan weet ik wel, wie spoedig oud-Minister van Arbeid zal zljn !", tekende een ontstemde Aalberse in zijn dagboek aan. ${ }^{55}$

Nolens sprak Aalberse moed in en bezwoer hem in geen geval de portefeuillekwestie te stellen. Maar toen Ruys eenmaal de rem op financiën had aangehaald, liep vooral de druk op arbeid snel op. Begin 1921 kwam Aalberse in botsing met vrijwel alle leden van het kabinet. De steunkassen voor werklozen waren leeg en op vinnige toon - "ik heb geducht van me afgebeten" - claimdie hij extra middelen.

De ministerraad kwam er iniet ult, en In deze Impasse vond nader overleg plaats met de leiders van de rechterzijde. Nolens trok parti] voor Aalberse, en tot zijn grote verontwaardiging kreeg Ruys door zijn wandelpartner voor de voeten geworpen: "Zolang we voor oorlog en marine $f 70$,- miljoen over hebben, kunnen we ook wel enkele miljoenen voor de werklozen uitgeven." ${ }^{56}$ De basis voor een sociaal compromis was daarmee gelegd, 
en ... de vrije val van de defensieuitgaven bleek nu niet meer te stuiten! "Met de drie Rechtsche fracties heb ik overlegd over de hoofdlijnen van een defensieprogram en wij zijn het eens geworden." ${ }^{57}$. schreef een als altijd optimistische Ruys op 29 maart 1920 aan Van Nispen.

Langs die gemeenschappelijke lijnen zou de nieuwe minister Pop het defenslebeleid verder moeten uitwerken. Toen Pop eind 1920 zijn conceptlegerplannen aan de kamer presenteerde, maakte AR-woordvoerder mr. V. Rutgers hem al snel duidelijk het legerconcept volstrekt onvoldoende te vinden. En Lohman voegde daar namens zijn fractie aan toe: "... het is misschien nlet onnodig daarop de aandacht van de regering te vestigen, dat voor een goede landsverdediging alle andere politieke consideraties moeten wijken." 58

Dat klonk als een ultimatum, aldus Oud, en dat bleek het over een halfiaar ook te zijn. ${ }^{59}$

\section{* Missie- en zendingsarbeid}

Na deze terugblik op oorzaak van en aanleiding tot de kabinetscrisis keren we nu terug naar de actualiteit van de crisis zelf.

Wanneer een kabinet in verband met de verkiezing van de Tweede Kamer of om andere redenen ontslag vraagt en demissionair wordt, hoort de koning eerst achtereenvolgens een vaste rij van raadslieden, namelijk de voorzitters van de Eerste en Tweede Kamer, de vice-president van de Raad van State en de fractievoorzitters uit de Tweede Kamer (in volgorde van de grootte van de fracties), zo beschrijft Van der Pot-Donner de huidige gang van zaken bij een kabinetsformatie. ${ }^{\infty}$

De vormgever van deze formatiepraktijk, dr. Louis Beel, is in 1921 pas een 19 jaar oude, tijdielijk ambtenaar ter gemeentesecretarie in Roermond, en het duurt dan ook nog een kwarteeuw eer het staatshoofd bij de kabinetsformatie mínder naar welgevallen en méér volgens een strikt patroon te werk gaat.

Een door dr. E. van Raalte ingesteld onderzoek ${ }^{61}$ lat zien dat het horen van de voorzitters van beide kamers en de vice-president van de Raad van State sinds 1894 vaste regel is - het onderzoek gaat overigens voorbij aan de uitzondering van 1921. De consultatie van fractieleiders start in 1905 , en is vanaf dat jaar tot ver in de jaren dertig een selectief proces, waarin de koningin nu eens aan álle fracties advies vraagt, dan weer met uitzonderlng van de SDAP of de hele linkerzijde.

Als Ruys de koningin op 16 juni 1921 het ontslag van de ministers aanbiedt, deelt Hare Majesteit hem mee: “... uit Amsterdam gekomen met 
overtuiging: oplossing Crisis te vinden in de reconstructie Kabinet: ${ }^{62}$ Na raadpleging van Ruys, Heemskerk, De Visser en de leiders van de drie rechtse fracties, besluit de koningin deze fracties te vragen nat hun bereidheid tot verdere samenwerking en onderlinge regeling van het milltaire vraagstuk en dat van de grondbelasting.

Op basis van de positieve reacties die de koningin van de drie kamerclubs ontvangt, geeft zij Ruys op 22 juni de opdracht het kabinet te reconstrueren. Maar de demissionaire premier wijst de koningin op de gebleken zwakte van de rechtse coalitie en geeft hat te kennen de opdracht niet te kunnen aanvaarden, indien niet óók de linkse fractielelders de gelegenheid krijgen, haar hun oordeel over de politieke situatie te geven. ${ }^{63}$ Dat moét dan maar, besluit Wilheimina inschikkelijk, en zó verschijnen op 25 junl Marchant, Schaper en de aanvoerder van de nileuwe Vritheidsbond, $\mathrm{mr}$. P. Rink, ten paleize om blijk te geven van hun niet-overwegende bezwaren tegen het aanblijven van het demissionaire kabinet.

Zonder dit oppositionele intermezzo af te wachten is Ruys Intussen druk in de weer om oplossingen te vinden voor de politieke én personele pinpunten. In gesprekken met fractieleiders, partijbonzen en demissionaire ministers peilt hij tegen welke prijs zij de coalitie wensen voor te zetten.

Op voorhand is het duidelijk wlé water in de wijn moet doen. Het is dus Nolens die als eerste een uitnodiging van Ruys ontvangt, en getweeën tijgen zij weer naar Scheveningen om te onderhandelen over het militaire vraagstuk en het al dan niet doorzetten van de - complete - opheffing van het processieverbod.

Dit laatste onderhandelingspunt betreft één van de door de regering in maart 1921 overgenomen voorstellen tot partiële grondwetsherziening van de staatscommissie-Ruys, welk onderdeel, naast grote tevredenheid in katholieke kring, ernstige tegenkanting ondervindt van hervormd Nederland en de CHU. ${ }^{64}$

Tijdens het Limburgse onderonsje op de boulevard blijkt weer eens hoeveel beide heren op hebben met de coalitie en het voortbestaan van het kabinet. Na een nuchtere analyse van de situatle komen zij tot de conclusie dat hun gemeenschappelijke doel haalbaar Is, maar dan moet wél de fel emotieve processiekwestie als "politiek onrijp" van tafel, is ombuiging naar protestants model van het defensiebeleid onvermijdelijk en behoeft het financleringstekort de allerhoogste aandacht.

Zij weten nu wat hun te doen staat. Nolens keert terug naar zijn fractle om haar stilaan voor te berelden op de nodige concessies, terwijl Ruys - hll heeft inmiddels de opdracht van de koningin aanvaard - zich gaat wijden aan zijn zendingstaak bij de protestantse coalitiegenoten. 
Een op de leest van de AR en de CHU geschoeide herziening van de dienstplichtwet, handhaving van het ontwerp van wet op de grondbelasting, forse bezuinigingsmaatregelen en vervanging van de ministers van financlën en defensle vormen de inzet van uitgebreid beraad in de eerstvolgende weken.

Medio juli heeft Ruys zijn reconstructieplannen rond en legt hil deze ter accordering voor aan de drie rechtse fracties. Ondanks zeker voorbehoud tegen de vaagheld van de bezuinigingsvoorstellen zijn de protestantse fracties bereid genoegen te nemen met de toezegging van Ruys dat de nieuwe minister van financiën voor nadere precisering zal zorgen. Ook de katholieke kamerclub verklaart het ontwerp-regeerprogram wel als basis voor verdere samenwerking te kunnen aanvaarden. Nolens' missiearbeid heeft kennelijk gebaat, "maar enthousiast is men over het algemeen niet", zo typeert Gribling de stemming van de vergadering. ${ }^{65}$

Na deze programmatische afslulting van de crisis bereikt Ruys op 26 juli ook een akkoord over het aantrekken van twee ministers. De antirevolutionair dr. J. van Dijk, directeur van de Topografische Dienst, komt op defensle en het christelijk-historische Tweede-Kamerlid, tevens burgemeester van Arnhem, Jhr. D. de Geer, gaat de financlën beheren. Twee dagen later beëdigt de koningin beide nieuwe ministers en pakt het gereconstrueerde kabinet de draad weer op.

\subsection{De echo van de Volkenbond}

Het is alles nieuwe bezuiniging, hogere belastingdruk, zoveelste defensiehervorming en langer werken wat de klok slaat op de derde dinsclag van september 1921. Met de Tweede-Kamerverkiezing van 1922 in zicht, lijkt de laatste zittingsperlode van het kabinet allerminst een oggstjaar te worden.

Maar de septembermaand brengt ook een aangename verrassing. In de tweede Assemblée van de Volkenbond valt die maand het besluit tot instelling van het Permanent Hof van Internationale Justitie en tot aanwijzing van Den Haag als plaats van vestiging.

Het Hof, dat zich kan uitspreken over geschillen die staten hem voorleggen, Is één van de internationale organisaties die deel uitmaken van de op 10 januari 1920 krachtens het Vredesverdrag van Versailles totstandgekomen - Volkenbond. Dit in Genève gevestigde "waarborginstituut" van internationale vrede en veiligheid beoogt ook de internationale samenwerking te bevorderen, en nam op dit terrein - als bond in oprichting - het 
initiatief tot de eerste Internationale Arbeidsconferentie van oktober 1919 in Washington, bij resolutie waarvan Aalberse tot de bekende pijnlijke revsie van de arbeidswet werd gemaand, die in 1922 haar beslag kriggt.

Anderhalf jaar na de toetreding van Nederland tot de overwinnaarsbond van Versailles is het internationale aanzien van die voormalige neutralist zodanig gestegen dat hij voor een bonus van de League of Nations in aanmerking komt. Het draait zelfs uit op een bonus met toegift, want de volkenrechtsgeleerde mr. Bernard Loder wordt gekozen tot de eerste president van het Hof.

De idealen van de Volkenbond doen inmiddels ook hun invloed gelden op binnenlands politiek terrein. De vredes- en veiligheidsgedachte van de statenbond vindt hler aanstonds in brede kring een goede voedingsbodem. Voor links en de linkervleugel van de katholieke fractie bieden de internationale ontwikkelingen een welkome gelegenheid om hun webekende bezwaren tegen de achtereenvolgende defensieplannen extra kracht bij te zetten.

In het laatste regeringsjaar staan de Haagse staatszaken voor een belangrijk deel in het teken van de hogere politiek van de machtscentra in Genève en Washington.

We besteden hierna aandacht aan deze supranationale inwerking op het landsbeleid en sluiten dit hoofdstuk vervolgens af met de puur nationale aangelegenheden van de wilziging van de kjeswet én de grondwet.

\section{* Vraagstukken van hogere politieke orde}

Het verdrag van Versailles heeft de bedoeling vermindering van bewapening te bevorderen, betoogt Van Karnebeek tijdens zijn verdediging in januari 1920 van het wetsontwerp dat de regering moet machtigen toe te treden tot de Volkenbond.

Met deze verklaring weet de minister van buitenlandse zaken de soclaalen vijzinnig-democraten voor zijn voorstel te winnen, maar onbedoeld rijdt hil daarmee wel zijn collega van oorlog behoorlijk in de wielen.

"... Van principiële verwerping van de landsverdediging was bij de Vrilheidsbond geen sprake ... Hier kwam het practisch probleem aan de orde: welke offers zullen gebracht worden ?", schrijft dr. L. de Jong. ${ }^{66}$ Nu deze nieuwe liberale partij in Van Karnebeeks woorden het begin van een internationale ontwapeningswedloop proeft, sluit zij zich dan ook onmiddellijk aan bij de taaie linkse oppositie als Van Dijk met zijn ontwerp-dienstplichtwet in december 1921 weliswaar van de eerder gelanceerde splitsing van het leger afstapt, maar wél de sterkte van de troepen opvoert. 
Alle stemmen van rechts, met inbegrip van de gedoogsteun van diverse katholieke afgevaardigden, heeft de minister nodig om zijn ontwerp er in belde kamers met minimale meerderheid door te krijgen.

De echo van het "waarborginstituut" heeft geklonken: de jaarlijkse defensleultgaven - van $f 207$ miljoen in 1919, in drie jaar tijd reeds tot $f 107$ miljoen gezakt - blijven vanaf 1922 aanhoudend verder dalen om in 1935 het dieptepunt van $f 76$ miljoen te bereiken. "Méér... wilden of durfden de successieve kabinetten niet vragen.", zo verklaart De Jong deze bezuiniging met "catastrofale gevolgen". 67

In december 1921 komen de vijf grote mogendheden - Amerika, Engeland. Frankrijk, Italië en Japan - te Washington bijeen om de maritieme bewapeningswedloop aan banden te leggen. Op voorstel van Amerika nemen de viff ter conferentie het besluit de bouw van slagschepen drastisch te beperken en hun gelimiteerde vlootsterkte in een vaste verhouding op elkaar af te stemmen.

Naast dit vlootverdrag leggen de vier belanghebbende mogendheden Italië blijft hier buiten - bij traktaat vast dat zil elkaars ellandenbezit in de Stille Oceaan zullen eerbiedigen. In een afzonderlijke verklaring tegenover de Nederlandse regering geeft elk van de vier te kennen dat hun Pacific Dea/ tevens de erkenning van onze insulaire bezittingen omvat.

Op 9 februarl 1922 doet Van Karnebeek de Tweede Kamer uitgebreid verslag van de door hem biligewoonde conferentie van Washington. Twee maanden later stelt zijn ambtgenoot van marine het ontwerp-vlootwet in de kamer aan de orde.

Waarom zou Nederland nog moeten overgaan tot de bouw van een vloot? Van Karnebeek is op dat moment op weg naar het buitenland en is dus niet bij de hand om het de goeddeels dwarse kamer nog eens haarfijn uit te leggen. Een motie van de vrijzinnig-democraat mr. P. Oud dringt aan op schorsing van de behandellng, en dit idee vindt bijval van Nolens, die zich met zijn fractie eerst van de paasplicht wil kwijten alvorens zich met zulke vervelende besognes in te laten.

De oude kamer komt, vlak vóór de verkjezing, niet meer aan de behandeling van het ontwerp toe. "De monseigneur heeft het voorstel prachtig van de baan gewerkt", gniffelt zilin dankbare achterban. ${ }^{68}$

\section{* Herziening van de kleswet}

De verkiezing van 1918, de eerste na invoering van het stelsel van evenredige vertegenwoordiging, bracht zeventien partijen in de Tweede Kamer. Terwijl voorheen het districtenstelsel "splinterpartijen" vrijwel geen kans 
bood, maar drong tot samenwerking en samengaan van verwante groeperingen, maakt het nieuwe stelsel de opstap naar een kamerzetel een stuk gemakkelijker voor een kleine partij. De kamer telt in 1918 llefst acht eenmansfracties; zes hiervan hebben hun plaats te danken aan toewijzing van een restzetel.

Het nieuwe stelsel met zijn vergaand versnipperende werking doet weldra de roep om wijziging van de methode van verdeling van restzetels kinken. De aanpak van deze omstreden regeling in 1921 is de eerste stap in een lange reeks van maatregelen en voorstellen die nog volgen. Voortaan is niet minimaal $50 \%$ van de kiesdeler, doch $75 \%$ nodig om een lijst met het grootste stemmenoverschot aan één restzetel te helpen.

Ofschoon na deze wijziging van de kleswet het aantal "splinters" in de kamer tot aan de Tweede Wereldoorlog sterk afneemt, moet in de "jacht" op de kleinere partijen, het systeem van de grootste overschotten in 1933 wijken voor dat van de grootste gemiddelden, dient een lijst sinds 1935 de volle kiesdeler te halen om voor een restzetel in aanmerking te komen en opent de grondwetsherziening van 1938 de mogelijkheid om de evenredige vertegenwoordiging aan een onevenredig hogere kiesdrempel te koppelen. Maar die gelegenheid is nog steeds niet benut, al zljn sindsdien wel diverse pogingen in het werk gesteld om de strikte evenredigheid te matigen. Na de kameruitbreiding van 1956 staan de kansen van een "splinter" op een kamerzetel zelfs gunstiger dan in 1921. Alleen gaat het nú om één of meer van de honderdvifftig !

Het gewicht van de voorkeurstemmen is in 1921 aanzienlijk beperkt. Wie, al dan niet na de stemoverdracht in de volgorde van de kandidatenlijst, de kjesdeler hadden gehaald, waren volgens de wet van 1917 gekozen. De overige aan de lijst toegewezen zetels kwamen vervolgens terecht bij de kandidaten die over de meeste stemmen beschikten. Voor kandidaten met voorkeurstemmen was dit systeem niet ongunstig, en bll de kamerverkiezing van 1918 leidde dat dan ook in zeven gevallen tot de door (een willekeurig aantal) kiezers én gekozene beoogde afwijking van de lijstvolgorde.

Een amendement van de sociaal-democraat ir. J. Albarda luidt het eind van dit kansspel in. Een kandidaat moet volgens diens voorstel minstens de helft van de kiesdeler vergaren, wil hij of zij met voorkeurstemmen worden gekozen. Ruys heeft als verantwoordelijke minister van binnenlandse zaken ernstige bedenkingen tegen die forse terugdringing van het kiezerscorrectief, maar spreekt daar niet het "onaanvaardbaar" over uit. ${ }^{69}$ Het systeem-Albarda, dat in 1921 wet wordt, maakt de beslissing van de partijapparatsjiks over de volgorde op de kandidatenlijst lange tijd vrijwel 
onaantastbaar, ook al kunnen sinds 1989 de in het hele land op een kandidaat uitgebrachte voorkeurstemmen blj elkaar worden opgeteld.

$\mathrm{Er}$ is eigenlijk niets mis met een voorkeursdrempel ingeval alle leden van de partijen lets te vertellen (zouden) hebben over de kandidaatstelling ... Maar de kieswet neemt in 1997 het zekere voor het onzekere: nú volstaat $25 \%$ van de kiesdeler om de kandidatenlijst eens flink door elkaar te schudden met voorkeursacties.

\subsection{De grondwetsherziening van 1922}

Het is op de kop af een maand geleden dat Ruys de kamer ingrijpende maatregelen ter bescherming van de grondslagen van ons politieke leven toezegde, als de regering op 20 december 1918 een staatscommissie instelt om een grondwetsherziening voor te bereiden.

De commissle, waarin onder voorzitterschap van Ruys de zes grootste partljen elk met één lid vertegenwoordigd zijn ${ }^{70}$, heeft de opdracht haar aandacht speciaal te richten op: de troonopvolging, het recht van oorlogsverklaring, het traktatenrecht, de samenstelling van de Staten-Generaal, het referendum met volksinitiatief en de vraag of het constitutioneel mogelijk is andere dan in de grondwet genoemde pubiekrechtelijke lichamen in te stellen.

Eind oktober 1920 brengt de commissie haar verslag uit. Op een enkele uitzondering ${ }^{71}$ na neemt de regering de voorstellen over en dient die op 22 maart 1921 in bij het parlement.

De ontwerpen doen geen geestdrift ontvlammen en de lauwe verdediging door Ruys dooft weldra het laatste sprankje vuur bij de volksvertegenwoordiging. De meeste van de betrekkelijk magere regeringsvoorstellen halen dan ook gladjes de eindstreep.

De grondwetsherzlening waar men in de euforie van eind 1918 zo'n hooggespannen verwachtingen van had, is dan ook vooral bekend om de hervormingen die in 1922 juist niet zijn doorgevoerd.

\section{* Wat verandert}

Diverse wél gerealiseerde wijzigingen zijn nochtans niet zonder betekenis. Naast de grondwettelijke vastlegging van het actief vrouwenkiesrecht behoren de herziene regelingen van de troonopvolging en de buitenlandse betrekkingen, alsmede de bepaling dat de wet ook aan andere dan in de grondwet genoemde lichamen verordenende bevoegdheid kan geven, tot de belangrijkste veranderingen van 1922 . 
Voor de troonopvolging komen nog slechts de afstammelingen van koningin Wilhelmina in aanmerking. Deze drastische beperking is een waarborg voor het behoud van "een waarlijk nationaa/ koningschap", zolang er tenminste een volgens de grondwet bevoegde opvolger is. Voor het geval dat zo'n opvolger ontbreekt, wil de staatscommissle de klezers laten beslissen over de aard van de staatsvorm, maar de regering acht de grondwet nlet de plaats en een referendum niet het middel om op een mogelijk andere staatsvorm te doelen. In het door haar ingediende ontwerp zijn het de Staten-Generaal die in dubbelen getale, in verenigde vergadering bijeenkomen teneinde een koning te benoemen.

In de kamerdebatten wijzen Oud en de katholieke afgevaardigde mr. J. van Schaik op de impasse die zou kunnen ontstaan als de benoeming van een koning - of anders het bewuste referendum over de staatsvorm - niet de vereiste tweederde meerderheid haalt, en er vervolgens evenmin zo'n meerderheid is voor een wijziging van de grondwet in republikeinse zin. Ruys voelt er echter niets voor naar de steen der wijzen te zoeken voor een niet-bestaand probleem. En vele grondwetswijzigingen later is er nog altijd geen probleem en is ook die steen nog niet gevonden.

Tientallen jaren na de bevestiging van het parlementaire stelsel had de volksvertegenwoordiging slechts een uiterst beperkte zeggenschap in aangelegenheden van buitenlands beleid. Toen de Tweede Kamer in mei 1917 aandrong op regelmatig overleg met de regering over de buitenland-. se betrekkingen, vond zij in premier Cort van der Linden een principiële bestrijder van dit voorstel: "... Medezeggenschap leidt noodwendig tot een gedeelde verantwoordelijkheid en deze zou in strijd zijn met de grondwet, [die] bij ons slechts drie machten [kent]: de rechterlijke macht, de wetgevende macht en de bestuursmacht, en de latste wordt uitgeoefend door de Koning alleen ..." 72

Onder de impuls van de oorlogservaringen en de internationale ontwikkelingen nadien krijgt het parlement in 1922 de nodige invloed op het buitenlandse beleid. Van een rol waarin de volksvertegenwoordiging haar zegje kon doen over voldongen feiten, komt voortaan haar zeggenschap tot uiting in het vereiste van haar voorafgaande toestemming tot een oorlogsverklaring en is ook het sluiten van verdragen van haar medewerking afhankelijk.

Met het artikel over andere lichamen met verordenende bevoegdheid maakt de grondwet in 1922 expliciet de baan vrij voor decentralisatie van de regelgeving. Deze grondwetsbepaling is een belangrijke bouwsteen van 
een nleuwe sociaal-economische ordening waarbinnen het beroeps- en bedrijfsleven de mogelijkheid heeft om zijn eigen rechtsorde te ontwikkelen en als uitvoeringsinstantie van bepaalde wetten te fungeren.

\section{* De vloed in ebbe verkeerd}

De democratiseringsdoelstelling is halverwege het proces in vrome wensen blijven steken. Op de peilkaart van Oud "...is de vloed van november 1918 thans reeds lang in ebbe verkeerd" ${ }^{73}$, en regering noch parlement wagen zich eraan de vraagstukken van de openbare godsdienstoefening buiten gebouwen en besloten plaatsen, het referendum met volksinitiatief en de Eerste Kamer tot een bevredigende oplossing te brengen.

Het regeringsvoorstel om het processieverbod op te heffen roept bij het voorbereidende onderzoek in de Tweede Kamer sterk uiteenlopende reacties op, waarna het ontwerp bij memorie van antwoord wordt teruggenomen. Met zijn fijn aanvoelingsvermogen constateert Troelstra dat "hier de kloof ligt die katholieken van de gereformeerden [maar vooral van de hervormden] scheidt" ${ }^{74}$, en zowaar verschilt hij daarin nagenoeg niet van gevoelen met Ruys en Nolens, zoals we zagen ...

Intussen blijven "kerkelijke optochten" verboden in gemeenten waar zij in 1848 niet gebruikelijk waren. Deze bevriezing van de toenmalige situatie zet welgeteld nog twee generaties door alvorens de grondwet in 1983 het ijs breekt en processies, na een aanhoudende dool van viff jaar, krachtens de wet van 20 april 1988 (Staatsblad nr. 157) overal onder de noemer van "openbare manifestaties" geoorloofd zijn.

Wil de regering van het door de staatscommissie voorgestelde referendum over de staatsvorm niets weten, anders is het met de eveneens aanbevolen volksraadpleging over een grondwetsherziening. In de lijn van de commissie stelt de regering voor, de tweede lezing van de herzieningsprocedure af te schaffen en het "sluitstuk van de democratie" in te zetten ingeval het herzleningsontwerp niet in beide kamers een tweederde meerderheid heeft behaald. Bij die eventuele volksstemming is voor de herziening wél een tweederde meerderheid vereist.

Met alle denkbare varianten gaan links en rechts het regeringsontwerp te lijf. ledereen blijkt wel van die tweede lezing af te willen, en ook vindt ledereen dat de grondwet minder gemakkelijk dan een gewone wet te wijzigen moet zijn. Maar de zaak loopt vast op het twistpunt of er in de eerste lezing en daama - eventueel - bij het referendum al dan niet een versterkte meerderheid nodig is voor de herziening. 
En alzo blijft de aanvechtbare herzleningsprocedure van 1848 tijdeloos voortbestaan, zonder dat een meerderheid van de kiezers - maar soms wèl een juist voor deze gelegenheid beperkte minderheid van de volksvertegenwoordiging - het laatste woord heeft over een grondwetswijziging.

De gedachte van de volkssoevereiniteit in de staatsregeling voor het Bataafsche Volk van 1798 klinkt door in een vrijzinnig-democratisch amendement dat door de Staten-Generaal aangenomen wetsvoorstellen wil onderwerpen aan een beslissend referendum indien minimaal 20000 klezers om zo'n volksuitspraak vragen.

Het amendement krijgt vrijwel geen steun van de kamer. Terwijl voor Troelstra, en met hem de meeste socialisten en liberalen, een referendum én behoud van de Senaat één "rem" te veel is, vinden Ruys en de rechtse fracties dat de toets van de wetgeving best aan een "vernieuwd onbevangen onderzoek" ${ }^{75}$ door de senatoren kan worden overgelaten. Maar dan kan er van afschaffing van de Eerste Kamer vanzelfsprekend geen sprake zijn!

\section{* Een sprookje afschaffen?}

Hoezo afschaffing van deze notabele instelling ? Hield zil inmiddels al niet ruim honderd jaar een wakend oog over de Tweede Kamer en had zl] daarmee het land niet voor overijlde besluiten en revolutionaire woelingen behoed ? ${ }^{76}$ Alles goed en wel, maar tijdens de novemberdebatten van 1918 bestond er een sterke stroming in de "volkskamer" die nu eindelijk eens de uiterste consequentie wilde verbinden aan Thorbeckes visie op dat Belgische misbakselvan 1815: "zonder doel en zonder grond". ${ }^{77}$

Naar veler mening had de "chambre de réflexion" die afstraffing - ze had het er de laatste decennia ook naar gemaakt - helemaal aan zichzelf te wijten. Zo verwierp zij in 1900 op puur politieke gronden het ontwerp-ongevallenwet, ofschoon dit wetsvoorstel met grote meerderheld de Tweede Kamer was gepasseerd. Vier jaar later oordeelde de Senaat over het ontwerp-hogeronderwijswet dat "de overzijde van het Binnenhof" alweer aan de waan van de dag had geofferd, waarop een krasse Kuyper die overwegend linkse club eens danig mores leerde. ${ }^{78}$

Grote populariteit verwierf de Eerste Kamer zich ook al niet toen zil in 1917 en 1918 de invoering van een premievrij staatspensioen voor behoeftigen boven de zeventig jaar tot tweemaal toe blokkeerde. Enkele jaren daarvóór had niemand minder dan prof. mr. H. Krabbe betoogd dat dé rechtsgrond voor het bestaan van deze kamer zou liggen in het toetsen van een wetsontwerp aan de rechtsovertuigingen van het volk. Maar belde 
keren had daar nu een rèchtse kamermeerderheid geen boodschap aan.

Anno 1918 is de Eerste Kamer vanwege haar diffuus imago - zij] is dát wat zij niet is - een dankbaar onderwerp voor heftige politieke discussie. In de striljuraag vóór of tégen behoud van deze kamer, au fond een gevecht tussen rechts en links, manifesteert zich evenzeer een botsing van tegengestelde belangen, en dergelijke contrasten komt men nu eenmaal in álle partijen tegen.

De staatscommissie komt in haar advies over de inrichting en de taak van de Senaat tot de conclusie dat de kamer moet blijven, maar dan wèl met een grotere kiezersinwloed op haar samenstelling: verkorting van haar zittingsduur tot vier jaar onder gelijktijdige aftreding van alle leden, verkiezing op de grondslag van evenredige vertegenwoordiging en ontbindbaarheid van de Provinclale Staten - het kiescollege - bij ontbinding van de kamer.

Aldus gedemocratiseerd is de kamer, volgens de commissie, bij uitstek de instantie voor toetsing van de wetsvoorstellen aan de volksovertuiging, en kan het verplichte advies van de Raad van State vervallen. ${ }^{79}$ Met uitzondering van dit laatste punt neemt de regering het advies van de staatscommissie geheel over.

Terstond bil de behandeling van het desbetreffende regeringsontwerp stelt Marchant bij amendement de afschaffing van de Eerste Kamer voor. Als organische vertegenwoordiging zou zij reden van bestaan kunnen hebben, maar in de samenstelling die de regering voor ogen staat, is zij slechts een overbodige doublure van de Tweede Kamer.

Dit vijzinnig-democratische geluid kinkt Troelstra en ook de vrijheidsbonder mr. A. Visser van IJzendoorn - "slechts de boden van die kamer zouden om haar uitvaart treuren" 80 - als muziek in de oren.

De weerklank die het ontwerp in de regeringsfracties vindt, is weinig harmonieus. De Provinciale Staten deugen niet als kiescollege om de Eerste Kamer het karakter te geven van een instantie van revisie die een tegenwicht kan vormen tegen de besluiten van de Tweede Karner, betogen de katholieke afgevaardigden Van Schaik en jhr. mr. A. van Sasse van IJsselt. Maar zolang een op die taak toegesneden samenstelling van de Eerste Kamer nog toekomstmuziek is, gunnen zij het regeringsvoorstel het voordeel van de twijfel. Daarentegen betreuren Rutgers (AR) en dr. J. Schokking (CHU) dat het ontwerp de banden met de provincies losser maakt, want juist in dié relatie is de kjem aanwezig om van de Senaat een organische vertegenwoordiging te maken.

Met herhaling van zetten: een gedemocratiseerde Eerste Kamer moet er voor waken dat haar tegenhanger offert aan de waan van de dag, bereikt 
Ruys dat de "waangevaarlijke" kamer het amendement-Marchant op 21 november 1921 nipt verwerpt en het regeringsontwerp vervolgens met grote meerderheid - er is zo gauw niets beters !? - aanvaardt.

In de Eerste Kamer zet mr. W.L. baron de Vos van Steenwilk (CHU) de toon bij de behandeling van het ontwerp. Waarom worden wij en niet $z \hat{j}$ gekortwiekt; hebben wij hler te doen met list of grenzeloze verwatenheld?, houdt hij zijn gehoor voor. ${ }^{81}$

Deze stekende woorden zetten de kamer op stelten. Niemand voelt ervoor zijn eigen doodvonnis te tekenen, gist sociaal-democraat W. Vliegen, en op goed geluk ... stemmen links en enkele katholieken en antirevolutionairen vóór, en de overgrote meerderheild van de rechtste fracties tégen het regeringsvoorstel.

Teleurgesteld over deze pijnlijke nederlaag op 20 april 1922 en met gepast zelfverwijt over zijn lauw verweer tegen al die oppositie uit de regeringsfracties, kan Ruys in het nabije Torentje even tot bezinning komen. ${ }^{82}$

Nauwelijks is Ruys van een "weinigje beroering" bekomen, of Troelstra bindt de kat de bel aan. De Tweede Kamer, zo stelt hij in zljin interpellatie van de minister, leed beslist niet aan de waan van de dag toen zil] zich met zo'n grote meerderheid (65-17) uitsprak voor de grondig voorbereide hervorming van de Eerste Kamer. Het veto van deze kamer doorstaat óók niet de toets van de rechtsovertuiging van het volk, aldus de interpellant.

Hij verlangt passende maatregelen van de regering en nodigt haar uit de Eerste Kamer te ontbinden en het ontwerp na de verkiezing van de kamer nogmaals aanhangig te maken; en zo niet, de grondwetsherziening geheel terug te nemen en die tot inzet van de aanstaande Tweede-Kamerverkjezing te maken, of anders de afschaffing van de Eerste Kamer te bevorderen. ${ }^{83}$

Hoeveel voor Troelstra's oordeel over het veto van de Senaat ook te zeggen valt, Ruys is niettemin tot niets anders over te halen dan de houding van die eigengereide senatoren ten zeerste te betreuren, en heeft verder geen enkele behoefte aan de tijdbommen die de soclaal-democraat hem zo gedienstig aanreikt. De regering is, Integendeel, juist van plan een eind tegemoet te komen aan de bezwaren die de coalitiefracties tegen het ontwerp hadden. Opdat rechts één blijve .... is de weinig gewaagde veronderstelling.

Binnen één week na de herrie over en met de Eerste Kamer ligt er een herzien ontwerp: zes jaar wordt de zittingsduur, om de drie jaar treedt de helft van de leden af en de ontbinding van de kamer heeft geen gevolgen voor de Provinciale Staten. 
Beide kamers gaan thans vlot akkoord, ook al is vrijwel niemand geheel voldaan over een Eerste Kamer die een doublure van Tweede Kamer is gebleven. Maar "je kunt een sprookje nu eenmaal niet afschaffen", zou een sociaal-democratische senator bij zijn uitverkiezing tot voorzitter van dit "wonderlijke genootschap" ooit zeggen. ${ }^{84}$

Na de bekrachtiging en de afkondiging van de eerste lezingswet wordt de zitting van de Staten-Generaal eind mei gesloten. Nu kan de verkiezingsstrijd oplaaien. En de grondwetsherziening ? Och, niemand maakt zich daar meer druk over, zodat na een geruisloze tweede lezing, de bekrachtiging van alle ontwerpen op 30 november 1922 kan plaatsvinden.

\subsection{Balans van vier jaar Ruys I}

"Gil waart de right man on the right place." ${ }^{85}$ Welke premier zou na goed twee jaar regeren niet tekenen voor zo veel lof als Ruys op 9 februari 1921 wordt toegezwaaid?

Een aardige opsteker, uit onverdachte hoek nog wel ! Het is immers de hoogbejaarde Lohman die het bij zijn afscheid van de landspolitiek van het hart moet hoezeer hem die uiterst ellendige benoeming van een roomse premler is meegevallen.

De éminence grise van de Nederlandse politici voelt de last der jaren. Het lidmaatschap van de Tweede Kamer wordt hem op 84-jarige leeftijd te zwaar. Maar zijn gave om scherp waar te nemen wat zich in het Haagse wereldje afspeelt, vertoont nog geen slijtage.

De prestaties van het kabinet mogen er zijn, oordeeit de oude staatsman. Inderdaad. Als hier in november 1918 even het schrikbeeld van een arbeiders- en soldatenrepubliek-Duitse-stijl opdoemt, staat Ruys pal in het gevaar en is het onder zijn vastberaden leiding dat het kabinet het spook van de revolutie verjaagt. Méér realo dan de rest van zijjn ministersploeg breekt Ruys dezelfde maand in de Tweede Kamer een lans voor het actief - vrouwenkjesrecht en weet zijn gezaghebbende stem de clubs van Nolens, Lohman en de liberalen te winnen voor het desbetreffende wetsinitiatief van Marchant. Een maand later oogst Ruys, na een gloedvolle verdediging van de hervormingsplannen van het kabinet, kamerbrede steun voor het sociale werkplan van Aalberse en de taakopdracht van zijn eigen grondwetscommissie.

Het is inmiddels laat in het jaar 1918. Het kabinet heeft zijn ongekend hectische aanloopfase achter de rug en kan nu eindelijk voluit aan zijn karwei beginnen. Met de snelheid die past bij de polsslag van deze tijd werkt 
het de eerste jaren een druk programma af. Op peildatum voorjaar 1921 ook voor Lohman is halverwege het derde regeringsjaar het geschikte moment om eens terug te blikken - geeft de tussenstand van tweeërhalf jaar Ruys aan dat zijn kabinet aardig koers houdt, ondanks sterke tegenstromen.

Aardig op koers, best wel I De sociale-wetgevingsmachine van Aalberse draait op volle toeren. Een ander kernpunt van het regeerprogram, de schoolwet, staat dankzij knap werk van De Visser al in het Staatsblad. Ruys heeft inmiddels de regeringsontwerpen voor de grondwetsherziening bi] de Staten-Generaal ingediend. En bij dat al heeft Van Karnebeeks krachtige protest tegen Belgiës politiek van landjepik de geallieerden er in Parijs van overtuigd dat vordering van Nederlands staatsgebled een weinig sjleke interventie in een burenruzie is.

Maar het kabinet heeft ook last van tegenstromen, en niet zo'n beetje ! De financiën raken langzamerhand behoorlijk in de war. Met marine en oorlog is ' $t$ van meet af aan al om te huilen. En dan zul je nu net op die drie posten brekebenen hebben zitten!

Het eerste regeringsjaar verloopt nog bijna vlekkeloos. Goed, de minister van marine nokt voortijdig af, de kamer maakt zich zorgen over de hoge defensieuitgaven, een van de kruisers wordt van de tafel geveegd, maar voor de rest is er zo te zien geen vuiltje aan de lucht in dit topjaar van de sociale wetgeving.

Het storingvrije verloop is echter niet van lange duur. Tijdens de begro: tingsbehandeling van 1920 barst heftige kritiek los op het beleid van de ministers van financiën, oorlog en marine. De schatkistbewaarder heeft geen notie van kostenbeheersing, zijn collega's van oorlog en marine doen maar raak en het slot van het liedje is dat de begroting bil lange na niet sluit.

Het sein staat op onveilig. En Ruys weet nu dat hij onmiddellijk moet ingrijpen wil zijn kabinet niet regelrecht op een crisis afstevenen.

Veel manoeuvreerruimte heeft de kabinetsleider echter niet. Een begrotingstekort van tientallen milloenen, almaar stijgende uitgaven, een belastingdruk op de grens van het toelaatbare, een brekebeen die niet voor de eer bedankt: wat moet je anders dan de rem op de financiën aanhalen en minister De Vries de wacht aanzeggen ?

Bezuinigen dus. Maar vraag je: waarop ?, moet je dan de verdeelde reacties van de coalitiefracties eens horen! De AR en de CHU geven geen duimbreed toe als de landsverdediging het gelag zou moeten betalen. De club van Nolens wil met alle geweld de sociale politiek voortzetten en daar komt bij dat onder de invloed van de hype van het gebroken geweertje, 
komt bil dat onder de invloed van de hype van het gebroken geweertie met name de "jongere heeren" in de fractie weinig op hebben met slokop defensie.

Wat nu ? Eerst maant Ruys schatkistbewaarder De Vries strak de hand te houden aan het ministerraadsbesluit van 1919, dat de minister van financiên alle ruimte biedt om zich nadrukkelijk met de financiële handel en wandel van zijn collega's te bemoeien. Hierna doktert de premier aan zorgenkind defensie. Leger en vloot zijn er niet best aan toe. Maar geluk$\mathrm{kig}$ is luitenant-generaal Pop bereid gevonden oorlog én marine voor zijn rekening te nemen, zodat nu eindelijk een patent iemand die janboel eens grondig kan doorlichten om vervolgens aan het saneren te slaan.

De premier is uitgedokterd. Het kabinet is weer uit de gevarenzone. Maar of een beetje bijstellen hier en uitstellen daar problemen helpen oplossen, is zelfs in de politiek niet helemaal zeker.

De toestand van onzekerheid duurt nog ruim één jaar. Dan struikelt De Vries over zilln grondbelasting, haalt Pop even later bakzijl met zijn legerplannen en bledt het kabinet daarop zijn ontslag aan.

Zo draait het medio 1921 uit op een kabinetscrisis die niet uitblijven kon. Het ontbreekt de protestantse en katholieke coalitiepartners immers aan consensus over hoofdlijnen van het regeringsbeleid, als de landsverdediging, de bestrijding van het financieringstekort en het tempo van de sociale hervorming. Bovendien liggen de CHU en de RKSP met elkaar in de clinch over de processiekwestle.

De rechtse samenwerking wankelt, maar Hare Majesteit is vastbesloten de coalitie met haar gezag te stutten. Vijf weken later is het kabinet gereconstrueerd. Na veel geconfereer en overleg heeft Ruys zich verzekerd van de nodige concessies van de katholieke kamerclub en de protestanten zijn zowaar tot een enkel compromis bereid.

In een opwelling van genegenheid had de AR-kamerfractie een tijdje geleden de loftrompet over de voortreffelijke eigenschappen van Ruys en diens grote bereldwilligheid tot overleg gestoken. Na zoveel tegemoetkomendheid van de premier, mogen de mannenbroeders nu wel wér uit hun dak gaan!

En de Majesteit, zou zilj na de struikeling van haar eerste staatsdienaar nog steeds vinden dat hij zich "... al aardig [heeft] ontwikkeld, meer Nederlandsch [is gaan] denken en voelen .... zooals wij in het hart des lands plegen te doen."? ${ }^{86}$ Vast wel, als dat laatste tenminste de maatstaf is!

"De behandeling der Grondwet ... is voor Charles geen succes geweest ... Hoe goed organisator en revolutiebestrijder ook, wetgever is Charles 
wie volgt? Daar heeft partijvoorzïtter Van Wijnbergen volkomen gelijk in.

Ruys is een manager, een man die het veeleisende premierschap combineert met binnenlandse zaken, tussen de bedrijven door een tijdlang koloniën, marine en oorlog waarneemt, bijspringt als collega's haperen en alles in het werk stelt om het evenwicht tussen de rivaliserende coalitiepartners te bewaren. Zo'n drukke baas, die bovendien geen uitgesproken studiezin en wetenschappelijke bagage bezit, is nu niet direct het ideaaltype om zich à tête reposée in grondwetskwesties te verdiepen.

Tòch verdienen de voorstellen van "zijn" staatscommissle waardering. En als de premier nu eens het machtswoord in de Tweede Kamer had gesproken om de - nipte - verwerping van het beslissende referendum over een grondwetswijziging te voorkomen ? Hij zou onherroepelijk zljn gaan strijken met de prijs van democratische-hervormer-van-de-eeuw ! 



\subsection{Inleiding}

Bij de kamerverkiezing van 5 juli 1922 - de eerste na de invoering van het vrouwenkiesrecht - behalen de rechtse partijen een afgetekende overwinning. De RKSP komt met een winst van 2 zetels (van 30 naar 32 ) uit de stembus en hoeft over dit resultaat - dat bovendien de Nieuwe Katholieke Partij buiten de kamer houdt - beslist niet ontevreden te zijn. De protestanten slaan echter de beste slag: het aantal zetels van de AR stijgt van 13 tot 16 , dat van de $\mathrm{CHU}$ van 7 tot 11, en dan is er óók nog de Staatkundig Gereformeerde Partij (SGP) die voor het eerst een kamerzetel binnenhaalt. De linkerzijde krijgt gevoelige klappen. Weliswaar weet de VDB ziljn 5 mandaten te behouden, maar de Vrijheidsbond raakt er liefst 5 van de 15 kwijt en ook de SDAP heeft zetelverlies (van 22 naar 20 ) te betreuren.

Rechts en links nemen in 1922 enkele opmerkelijke nieuwelingen zitting in de kamerbanken. De uiterst rechtse positie in de vergaderzaal is voor G.H. Kersten. Deze ultra-orthodoxe dominee heeft zich inmiddels van de "rekkelijke" antirevolutionairen afgewend en draagt voortaan namens de door hem opgerichte SGP zijn rigide calvinistische boodschap uit: compromisloos, katholiekvijandig èn confronterend voor de beide stamverwante, grote protestantse partijen.

Het belangrijkste nieuwe Tweede-Kamerlid is ongetwijfeld Hendrikus Colijn. Eind maart 1922 nam hij ontslag als directeur van de BPM om zich met volle kracht te kunnen wijden aan de landspolitiek en aan zijn partij, waarvan hil sinds twee jaar officieel voorzitter is. Amper terug in Nederland aanvaardt deze geboren leider een aantal sleutelfuncties: hoofdredacteur van De Standaard, directielid van de Vrije Universiteit, lid van de Tweede Kamer en voorzitter van de antirevolutionaire kamerclub. In enkele maanden tijd zit Colijn vast in het zadel. De grote politieke rol van de ware opvolger van Kuyper gaat nu ècht beginnen.

Onmiskenbaar duidt de verkiezingsuitslag op een wisselwerking tussen actief en passief vrouwenkiesrecht. Op één uitzondering na zetten alle grotere partijen vrouwen op de kandidatenlijst, met als resultaat dat de twee herkozen 'vrouwelijke parlementariërs gezelschap krijgen van vijf nieuwe seksegenotes.

Alleen in de zestientallige fractie van de mannenbroeders is voor de zus- 
ters in den Here vooralsnog geen plaats. De ARP had immers in 1921 de verkiesbaarheid van vrouwen principieel afgewezen en zou dit besluit pas in 1953 herroepen.

\section{* Het kabinet bliff zitten}

Op 7 juli spreken Nolens en Ruys uitvoerig na over de verkiezingsuitslag. Het stembusresultaat is gunstig en getuigt, naar hun idee, van een duidelijk vertrouwen in het gevoerde beleid. Waarom dan een kabinetscrisis riskeren en vervolgens allicht weer, net als in 1918, verzeild raken in een moeizame formatie ? Nee, het kabinet moet eenvoudig aanblijven en goede afspraken maken met de regeringsfracties over het regeerprogram en de bezetting van enkele ministersposten.

Later op de dag komen de ministers in vergadering bijeen. De bewindslieden zijn unaniem van mening dat het kabinet op zijn post moet blijven, zonder de koningin hun ontslag aan te bieden.

Op 10 juli, als de koningin Ruys in audlientie ontvangt, stelt hij haar van het kabinetsstandpunt op de hoogte. De mededeling van de eerste minister brengt de koningin in een lastig parket. 24 jaar zit Wilhelmina inmiddels op de troon en al die tijd was er niet één kabinet dat haar na de kamerverkjezing zonder omhaal van woorden kwam melden: "wij blijven". Wèl was het in 1908 aangetreden kabinet-Heemskerk na de rechtse verkiezingswinst van 1909 gewoon blijven zitten, maar dáár had de vorstin dan ook zélfop aangestuurd. En nu komt zo'n vrijpostige Ruys haar zljn niet geheel onomstreden kabinet zomaar opdringen.

Verrast, zij het niet aangenaam, door haar eerste staatsdienaar, vuurt Hare Majesteit een meesterschot op hem af: heeft $u$ er bezwaar tegen dat ik eerst mijn drie vaste raadslieden - de vice-president van de Raad van State en de beide kamervoorzitters - en de leiders van de grote fracties over cle politieke toestand raadpleeg?

Deze vraag treft de premier pijnlijk. Vorige zomer immers wilde hij haar opdracht om het kabinet te reconstrueren niet aanvaarden als zij niet eerst op zijn dringend verzoek alle fractieleiders zou horen over haar plannen. En een jaar later betaalt zil hem met gelijke munt! Weigeren kan niet meer, en "Ruys, door de vraag overvallen, beging de fout terstond te antwoorden: neen, geen bezwaar" ${ }^{2}$, aldus een bestraffende Aalberse.

En zó ontstaat na deze onverwachte wending in het gesprek ten paleize de merkwaardige situatle dat de koningin, met goedvinden van de premier, de raad gaat inwinnen van haar adviseurs over de vraag of dit kabinet kan blijven zitten of dient op te stappen.

Het kabinetsbesluit van 7 juli staat daarmee op losse schroeven. Een kabi- 
netscrísis lijkt nauwelijks meer af te wenden.

De koningin consulteert

De volgende dagen is het een komen en gaan op Het Loo. Eerst maken de drie vaste raadslieden hun opwachting en sterken de koningin in haar opvatting dat het raadzaam is de fractieleiders te consulteren.

Vervolgens zijn de clubvoorzitters aan de beurt. Het kabinet-Ruys behoort zijn ontslag aan te bieden, vindt Marchant, en zodoende de Kroon de gelegenheid te geven de gangbare procedure van een kabinetsformatie in werking te stellen. Ook Colijn en Schokking spreken zich uit voor een normale formatie, die zou moeten leiden tot een nieuw, rechts kabinet, als het even kan met een ... protestantse premier. Troelstra kan billijken dat het kabinet na de versterking van de rechtse meerderheid blijft zitten, maar wil wel af van een katholieke premier, omdat katholieke politici voor zijn gevoel aan het touwtje lopen van het eplscopaat, dat hun zoal verbiedt samen te werken met socialisten. Nolens wijst in zijn onomwonden pleidooi voor het aanblijven van het kabinet op de verkiezingsultslag, het belang van de continuiteit van het beleid en de goede prestatles van de zittende ministers. Zo prijst hij, die anders bepaald niet scheutig is met zijn complimenten, Ruys om diens "flinke optreden in november 1918" en diens bekwaamheid "ook in het verkeer en de verstandhouding met de rechtsche groepen". ${ }^{3}$ Hier spreekt de meesterlijke tacticus, de man die weet te prijzen als het op aanprijzen aankomt ...

Deze wirwar van adviezen brengt de koningin ertoe de oude, wijze Minister van Staat Lohman te ontbieden. De voormalige voorman van de $\mathrm{CHU}$ toont zich bezorgd over de uitdijende machtspositie van de roomsen, die naast het premierschap inmiddels ook het voorzitterschap van belde kamers in bezit hebben. Wil er aan deze ongewenste cumulatie van functies een eind komen, dan moet om te beginnen een vertrouwd lemand het kabinet per ommegaande duidelijk maken dat Hare Majestelt wenst te beschikken over de portefeuilles. En dat signaal behoort de koningin vooral niet zèlf af te geven, want dat zou haar in conflict kunnen brengen met haar ministers, luidt het constitutioneel prudente advies van de raadsman. Maar zou een verstandig man als minister De Geer niet uitermate geknipt zijn voor die taak?

$\mathrm{Na}$ dit behartigenswaardige advies van de éminence grise van de Nederlandse politici heeft de koningin op 18 juli opnieuw een onderhoud met Ruys. "Indien het Kabinet de verantwoordelijkheid op zich durft nemen, om in deze moeilijken tijd aan te blijven, heb tk geen reden, om van mijn 
grondwettelijk recht gebruik te maken." ${ }^{4}$, verklaart zij hem ijzig, waarna de premier kan vertrekken zonder lets te weten te komen over de aan haar uitgebrachte adviezen.

Met een naar gevoel neemt de premier afscheid en brengt meteen verslag uit aan zijn collega's. Voor de christelijk-historische ministers zou het kabinet er in de gegeven omstandigheden verstandig aan doen alsnog de portefeuilles ter beschikking te stellen, maar de andere bewindslieden dringen aan op openheid van zaken om hun positie te kunnen bepalen.

En wéér gaat Ruys die dag ziljn licht opsteken bij de koningin. Zij vertelt hem enkele details uit de adviezen, waar hij niet wijzer van wordt. Ja tòch, één bijzonderheid is nieuw voor hem: twee rechtse fractieleiders zijn vóór terbeschilkingstelling van de portefeuilles.

Núl wordt het spannend en wil hij dat zij hem alle adviesstukken van de fractleleiders laat lezen. Daar voelt de koningin niets voor, maar na enig aandringen van Ruys is zij bereld de fractieleiders te vragen of de premier hun vertrouwelijke schrifturen aan haar mag inzien. ${ }^{5}$

Terug van het bezoek aan de koningin zet Ruys terstond het beraad met zijn ministers voort. Nu twee rechtse fractieleiders - en dat móéten Colijn en Schokking zijn I - blijkbaar tegen het kabinetsbesluit zijn, rest ons niets anders dan onze portefeuilles ter beschikking te stellen, oordeelt de vergadering, maar de adviezen van de fractieleiders willen wij per se in handen krilgen. ${ }^{6}$

Voor de derde maal begeeft Ruys zich die dag naar het koninklijke werkpaleis aan het Noordeinde. Dertien dagen na de verkiezingen is het kabinet eindelijk demissionair I Wèl ontvangt het in deze onbegeerde positie drie dagen later keurig alle opgevraagde stukken ...

Een kabinetscrisis met zo'n bizar voorspel als in 1922 komt nadien niet meer voor. Voortaan stellen kabinetten bil gelegenheid van een TweedeKamerverkjezing steevast hun portefeuilles ter beschikking van de koningin, en zí) beschouwt de aan haar uitgebrachte formatieadviezen niet langer als een toebehoren van het kroondomein. De Nederlandse politiek is in één klap twee spelregels rijker ! ${ }^{7}$

\section{* De Geer informateur}

Bulten voorkennis van Ruys ${ }^{8}$ ontvangt de koningin op 19 juli de minister van financiën De Geer. Zij verzoekt hem, vertrouwelijk te onderzoeken of rechts bereid is hem te accepteren als formateur. De Geer, door Lohman reeds ingeseind over alle eventualiteiten, voert nog dezelfde dag een gesprek met Colijn. Deze door velen gedoodverfde kandidaat voor het premierschap houdt echter de boot af en raadt zijn onverwachtse mededin- 
ger naar het toonaangevende staatsambt aan "om geen verdere stappen te doen, alvorens hilj zich eerst vergewist had van de houding, die de Roomschen eventueel zouden aannemen." "

Naar die houding hoeft De Geer nlet lang te gissen als hij op 20 jull ziljn geheime informatieopdracht met Nolens bespreekt. Het zint de katholieke-fractieleider allerminst dat het kabinet alsnog zijn portefeuilles ter beschikking heeft gesteld. En nú krijgt hij bovendien de vertrouwelijke mededeling dat de koningin, geheel tegen zijn advies in, uit is op een nieuw kabinet, onder nieuwe leiding, van De Geer nog wel: "Heeft [die] de eigenschappen om leider te zijn !?" 10

Nee, de stille informateur is bil Nolens aan het verkeerde adres, ook al will deze nog wel kort over de plannen nadenken en hem pas morgen uitsluitsel geven.

De volgende dag laat Nolens De Geer weten dat de katholieken alleen een kabinet-Ruys wensen. De kans op een kabinet-De Geer is daarmee verkeken.

De informateur staat op het punt zijn opdracht terug te geven. Voor een tegelijkertijd demissionaire minister is het dan hoog tijd om de ministerraad in te lichten over zijn geheime missie - alleen Ruys en Heemskerk had hij meteen geïnformeerd over zijn opdracht - èn het negatieve resultaat daarvan: een schulver waarvoor hem overigens geen enkele collega enig medelijden toont ...

Het is vroeg in de middag van zaterdag 22 juli als De Geer zijn informatieopdracht in Het Loo terugbezorgt. Om half twee rinkelt de telefoon op " $t$ " Suideras, het buiten van Ruys' schoonfamilie in het Gelderse Vierakker. Of de - demissionaire - premier zijn weekend even wil onderbreken om naar Apeldoorn te komen? 's Avonds geeft de koningin hem de opdracht een nieuw kabinet te vormen.

\subsection{Ruys formateur}

Bij het begin van de nieuwe werkweek draait de zojuist benoemde formateur meteen op volle toeren. Met de ene na de andere minister verdiept hij zich in de actuele politieke situatie, de beleidslijnen voor de komende jaren en diverse portefeuillekwesties.

In zijn gesprek met Nolens gaat het in hoofdzaak over de gevoelige relatie met de protestantse regeringspartijen. De behoedzaamheid gebiedt de formateur dat hij er eerst achter komt hoe zij tegen zijn formatiepoging aankijken. Op voorstel van Nolens schrijft Ruys op 26 juli een brief aan de drie rechtse fracties, waarin hij hun vraagt een kabinet onder zijn leiding te 
steunen indien men het eens kan worden over het regeerprogram waar hij druk mee bezig is."

Na ontvangst van een positieve reactie van de RKSP en de AR en een "vrijblijvende" van de CHL, stuurt de formateur de drie fracties op 1 augustus zijn ontwerp-program toe. Het nieuwe kabinet heeft de taak met voorrang het evenwicht tussen inkomsten en uitgaven te herstellen, waartoe forse besnoeling op alle departementen nodig is. Voorts wil het ontwerp de behandeling van de vlootwet aanhouden om een commissie de gelegenheid te geven de regering te adviseren over de omvang en het tempo van de vlootaanbouw. ${ }^{12}$

In het antwoord van de fracties aan Ruys uiten de CHU en AR kritiek op de vaagheid van de vlootparagraaf, terwijl de RKSP zich akkoord verklaart met het ontwerp-regeerprogram. De fracties nemen daamaast alle drie de vri|heid, de formateur te herinneren aan een netelige zaak: het gezantschap bij de paus.

Inderdaad, het ontwerp zwijgt over de Vaticaankwestie. Na de commotie die deze kwestie vorig jaar in de coalitie teweegbracht, voelt de formateur er niets voor die affaire op te rakelen.

\section{* De Vaticaankwestie}

Deze aloude strijdvraag gaat terug tot 1870 toen de kerkelijke staat en Rome bil het nieuw gevormde koninkrijk Italië werden ingelijfd.

De liberalen, die de liberaal-nationalistische wederopstandingsbeweging het Risorgimento - in Italië toejuichten, waren er als de kippen bij om een eind te maken aan het gezantschap bij - wat zij vonden - het hoofdkwartier van een genootschap van louter kerkelijke importantie.

Nochtans werd datzelfde hoofdkwartier in Città del Vaticano bij het begin van de Eerste Wereldoorlog - dankzij vredesinitiatieven van stedehouder Benedictus XV - hét knooppunt van het mondiale diplomatieke verkeer.

Ook het neutrale Nederland dacht zich in die oorlogstijd een bemiddelaarsrol toe, maar zat in een diplomatiek isolement doordat het in 1872, met veronachtzaming van "zekere imponderabilla" 13 , - als enig land - de betrekkingen met de kerkvorst-zonder-wereldilijke-macht had verbroken. Nederland dreigde dus buiten spel te blijven als het niet de breuk met het Vaticaan zou herstellen.

Dat nu uitgerekend een liberaa/ kabinet voor die opgaaf stond ! Geen nood, want "Regeren, de juiste maatregelen treffen, dat was vóór alles nodig en dit geschledde dan ook, dankzij het verstandige en vooruitziende beleid van het kabinet-Cort van der Linden", schrijft een bij hoge uitzondering lovende Wilhelmina in haar memoires. 
Natuurlijk wist deze hemelhoog geprezen premier ook met dít akkefietje raad: daar had hij immers zijn relatie in de oppositiebanken voor. En zó vertrok priester-oppositieleider Nolens in het voorjaar van 1915 als vertegenwoordiger van Hare Majesteits regering met een vertrouwelijke missie naar het Vaticaan om "poolshoogte" te nemen of een tijdelijke vertegenwoordiger van Nederland bij Zijne Heiligheid welkom zou zijn. ${ }^{\text {is }}$

De missie resulteerde in een pauselijk placet, waarop het parlement bij suppletoire begrotingswet in juni de middelen voteerde voor een tijdelijk en bijzonder gezantschap bij het Vaticaan.

Kon zowel de AR als de CHU in 1915 instemmen met het wetsontwerp van "zuiver opportunistische aard", toen het parlement echter het gezantschap op voorstel van de minister van buitenlandse zaken in 1921 permanent maakte, waren de christelijk-historischen daar faliekant tegen. De tweespalt die de Vaticaankwestie toen in de coalitie veroorzaakte, en als een splijtzwam ging werken, zou niet zonder gevolgen zijn voor de kabinetsformatie van 1922 en de periodes daarna.

\section{* Op zoek naar een gemeenschappelljke basis}

Het commentaar van de fracties op het ontwerp-regeerprogram maakt het de formateur niet gemakkelijk. Over de voorgestelde bezuinigingen hard nodig in deze tijd van economische neergang - is het laatste woord nog niet gesproken, maar daar is in goed overleg wel uit te komen. Minder hoopvol staan de zaken ervoor met de vlootwet. De protestantse fracties willen er eindelijk haring of kuit van hebben. Maar het lijkt wel of de katholieke kamerclub de inschakeling van een adviescommissie nog niet zo'n gek idee vindt om de vloot op lange baan te schuiven.

En als kjap op de vuurpijl komt daar bovendien die Vaticaankwestie bij. Hier lijken de standpunten, vooral tussen de CHU en de RKSP, onoverbrugbaar. De christelijk-historischen ziln namelijk van plan bij de eerste de beste gelegenheid in de kamer de aanval te openen op de gezantschapspost die, naar hun mening, in vredestijd geen algemeen landsbelang meer dient en slechts het roomse prestige moet ophouden. Van hun kant eisen de katholieken de garantie dat de coalitiepartners in de komende regeerperiode niet zullen tornen aan het gezantschap bij de paus. Hier botsen katholieke èn hervormde hardnekkigheid tegen elkaar, zonder dat een gereformeerde buffer- die zich in deze kwestie alle rechten voorbehoudt - de stoot kan breken.

Zo'n anderhalf jaar nadat Van Karnebeek het parlement wist te overtuigen van het nut van een permanente vertegenwoordiging bij het Vaticaan, moet een formateur die zelf onwrikbaar vasthoudt aan die diplomatieke 
post, tot een schikking zien te komen met drie partijen die het op dit punt finaal oneens zijn met elkaar.

Vier weken is Ruys inmiddels formateur en zilln werk wil maar niet vlotten. De Vaticaankwestie zit muurvast, de "vlootbasis" is nlet anders dan losjes te noemen, terwijl bovendlen de tijd - de derde dinsdag in september naakt 1 - begint te dringen.

De formateur is hard toe aan topberaad om de situatie zo snel mogelijk tot klaarheld te brengen. Op 23 augustus ontvangt Ruys de vertegenwoordigers van de drie rechtse fractles in het Torentje.

De voorgestelde bezuinigingen gaan de drie afgevaardigden niet ver genoeg, waarop de formateur toezegt het regeerontwerp op dit punt aan te scherpen.

Over de vootkwestie vinden de heren elkaar op de volgende formule: "In verband met de toestand der Nederlandsche en Nederlandsch-Indische financiën zal nader onderzocht worden in welk tempo de aanbouw van de in de vlootwet voorgestelde vloot zal plaats hebben zulks met handhaving van de scheepstypen in het ontwerp-vlootwet opgenomen en van de termijn van aanbouw van 6 jaren. In afwachting daarvan wordt behandeling van het vlootontwerp aangehouden." 16

Eén kllp is in elk geval met veel verbaal kunst- en vliegwerk omzeild. Maar dan moeten de heren toch óók in staat zijn een modus vivendi voor die andere helkele kwestie te bedenken !?

Het Torentjesoverleg brengt het viertal evenwel geen stap dichter bij de oplossing van de Vaticaankwestie. Nolens benadrukt dat zijn partij onder geen voorwaarde deelneemt aan een kabinet dat opheffing van het gezantschap niet radicaal afwilst. Schokking verwijt Nolens en Ruys dat zij van de $\mathrm{CHU}$ wel een erg hoge prijs vragen voor de voortzetting van de coalitie, maar hij past ervoor zich op dit moment, zonder nadere raadpleging van zijn fractie, het stempel van breker van de rechtse samenwerking op te laten drukken. En dat will Colijns vakantiewaarnemer, F.H. de Monté verLoren, al zeker niet op zlịn geweten hebben. Het katholieke duo heeft hoog ingezet. Het bod is nu aan de andere twee.

Enkele dagen later delen de belde protestantse fracties Ruys mee dat zij in het belang van de totstandkoming van een rechts kabinet niet zelf een voorstel tot opheffing van het gezantschap zullen doen. Komt een ander met zo'n Initiatief, dan zilin de fractieleden vrij in hun stemgedrag. it

De formateur beschikt nu wel over de "ulterste concessie" van de CHU en de AR, maar het gevaar ligt nog steeds op de loer. Een initiatief van een ander, dấár is hil met die antipapistische nieuweling in de kamer niet tegen gevriliwaard... 
Op 29 augustus bespreekt Ruys de stand van zaken met Nolens. De "uterste concessle" van de protestanten biedt weinig zekerheid, stelen belde heren vast. Maar als de katholieken dat bescheiden gebaar afwijzen, krijgen zij natuurlijk de schuld van de mislukking van de formatie. De zaak kan dan ook maar beter doorgaan, mits de fractie daamee instemt.

Drie dagen later kan Ruys met het akkoord van de katholieke kamerclub aan de slotfase van zijn formatiewerk beginnen.

\section{* Het regeerakkoord}

Nu de Vaticaankwestie niet langer een struikelblok voor Ruys is, lijkt niets een snelle afwikkeling van de kabinetsformatie nog in de weg te staan. De formateur en de vertegenwoordigers van de drie rechtse fracties zijn het immers in het Torentjesoverleg van 23 augustus reeds eens geworden over een aantal hoofdlijnen van het regeerprogram. En Inmiddels beschikt de formateur ook al over de toezegging van de kandidaten voor negen van de tien voorziene ministersposten.

Op 4 september voeren Ruys, Nolens, Colijn en Schokking hun eindbespreking over het regeerprogram. De hoofdtaak van het kabinet, zo leggen zij vast, bestaat in het herstel van het evenwicht tussen de inkomsten en de uitgaven van het Rijk. Waar in deze tijd van recessie niet te denken valt aan verhoging van de directe belastingen, moet een ingrijpende bezulniging van minstens $17 \%$ op de uitgaven van alle ministeries zorgen voor dekking van het geraamde begrotingstekort van $f 110$ miljoen over 1923 en het deficit dat in de twee kabinetsjaren daama te verwachten is. Tevens bevestigen de vier heren de in het Torentje gemaakte afspraak over de vlootwet. Het kabinet kan daarmee rekenen op de steun van de drie fracties bij de uitvoering van een in twaalf jaar te bekostigen bouwplan dat in een tijdsbestek van zes jaar een vloot moet opleveren, bestaande uit 2 kruisers, 12 torpedobootjagers, 26 onderzeeboten en 2 mijnenleggers. Alleen gaat een staatscommissie eerst nog even onderzoeken, welk tempo nodig is om een en ander in zes jaar rond te maken ... ? ।

Als lieder van de vier vervolgens ook met de wetgevingsparagraaf en de overige onderdelen van het regeerprogram kan instemmen, bekrachtigen de formateur en de drie fractieleiders de aldus bereikte overeenstemming over de hoofdlijnen van de politiek in de komende kabinetsperlode met hun handtekening.

De slotclausule van dit regeerakkoord vermeldt: "Zljnde dit in viervoud ondertekend door de vertegenwoordigers der AR-, $\mathrm{CH}$ - en RK-TweedeKamerfracties en den Kabinetsformateur, ten bewijze van overeenstemming inzake het optreden van den formateur op dit program, waardoor de 
drie fracties tegenover elkander en tegenover den formateur gebonden zijn tot het verlenen van steun in essentiële punten aan het Kabinet en leder van zijne leden." 18

De slotclausule vertoont de sporen van een kabinetsformatie die voor de helscleuren is weggehaald. Uiteenlopende taxatie van de ernst van de financiële situatie en de in dat kader te treffen maatregelen, ambivalente gevoelens over de noodzaak van zo'n begrotelijk vlootplan en de rusteloos voortwoekerende splijtzwam van de tijdelijk verdrongen Vaticaankwestie werpen donkere schaduwen op de coalitie. Tegen die achtergrond van zakelijke en psychologische verwijdering tussen de partijen die zijn betrokken bij de kabinetsformatie, zien de formateur en de drie rechtse fractieleiders in de binding aan het regeerakkoord het laatste redmiddel om de komende kabinetsperiode de nodige vastigheid te geven.

"Gestold wantrouwen" noemt Ruys' politieke erfgenaam Lubbers dat later, toen oppassen voor coalitiepartners heel gewoon was.

Bi) de kabinetsformatie van 1922 is het voor het eerst dat fractieleiders èn fracties daarbij zo sterk op de voorgrond treden.

Wèl legde formateur Kuyper in 1901 al eens zijn concept-regeerprogram ter beoordeling voor aan een werkgroep uit de kamerfracties van de AR en de RKSP, en zetten de achtereenvolgende formateurs Nolens en Ruys in 1918 samen met de top van de drie rechtse fracties een aantal hoofdlijnen van het regeringsbeleid uit. Maar de parlementaire formatiemethode van 1922 met haar nauwe betrokkenheid van de christen-democratische fracties en met een regeerakkoord als sluitstuk, is een novum.

Een regeerakkoord verschilt namelijk wezenlijk van een regeerprogram. ${ }^{19}$ Als een kabinet optreedt met een tussen de formateur en de (kandidaat-) ministers vastgesteld regeerprogram en het aldus zijn eigen verantwoordelijkheid voor het regeringsbeleid benadrukt, bindt dit program alleen de ministers en nlet tevens (de meerderheid van) de kamer. Wil er bij deze ministerlële formatiemethode met haar dualistische trekken sprake zijn van een vertrouwensband tussen kabinet en kamer, dan mag de kleur van het kabinet, zo die al nlet dezelfde is als van de meerderheid van de kamer, zeker niet te fel afsteken tegen het kleurengamma van de volksvertegenwoordiging.

Een regeerakkoord daarentegen is het positieve resultaat van het onderlinge overleg van de formateur en de bij het formatieproces betrolken fracties over de hoofdlijnen van het regeringsbeleid. In deze parlementaire formatiemethode zit een monistische inslag als gevolg van de wederkerige binding van het kabinet en de coalitiefracties - in de Tweede Kamer - aan de bepalingen van het akkoord. 
Zo laat het zich ook verklaren waarom het regeerakkoord van 1922 met geen woord rept van het niet-aanvalsverdrag inzake het gezantschap bij de paus!

Tien ministers moeten nu de zware kar gaan trekken. Het ministerie van landbouw, nijverheid en handel wordt het slachtoffer van de bezuiniging. Landbouw verhuist naar binnenlandse zaken en de overige taken van het opgeheven ministerie gaan over naar arbeld. Daarnaast komt na ruim twee jaar weer een eind aan de personele unle van oorlog en marine.

De zaak is bijna rond. Ruys heeft twee nieuwe ministers voor zijn kabnet: de Delftse hoogleraar ir. G.J. van Swaay (RKSP) is bereld waterstaat voor zijn rekening te nemen en de partijloze E.P Westerveld, directeur-generaal van de posterijen, tekent voor marine.

Op de overige posten keren de oude ministers terug. Alleen van De Geer, net terug van vakantie, moet Ruys nog het jawoord krijgen. De formateur is hoogst verbaasd als de beoogde minister van financiën grote budgettaire bezwaren blijkt te hebben tegen het door zijn eigen CHU-fractie aanvaarde vlootakkoord ${ }^{20}$, en nu opeens verantwoordelijkheid afwljst voor het onlangs met diens mede-ondertekening bij de kamer ingediende wetsontwerp.

Op het allerlaatste moment dreigt de formatie toch nog te floppen. Ruys heeft niemand anders voor financiën. En als een kat in het nauw zoekt hij zljn heil in een compromis waarmee de beoogde ministers van financiën en marine voorlopig wel kunnen leven: we onderwerpen het vlootgeschil aan het Salomonsoordeel van de nog in te stellen staatscommissie.

Het ene probleem oplossen, het andere creëren: het is een noodgreep, maar de formatiepoging van Ruys is op 11 september 1922 geslaagd. 


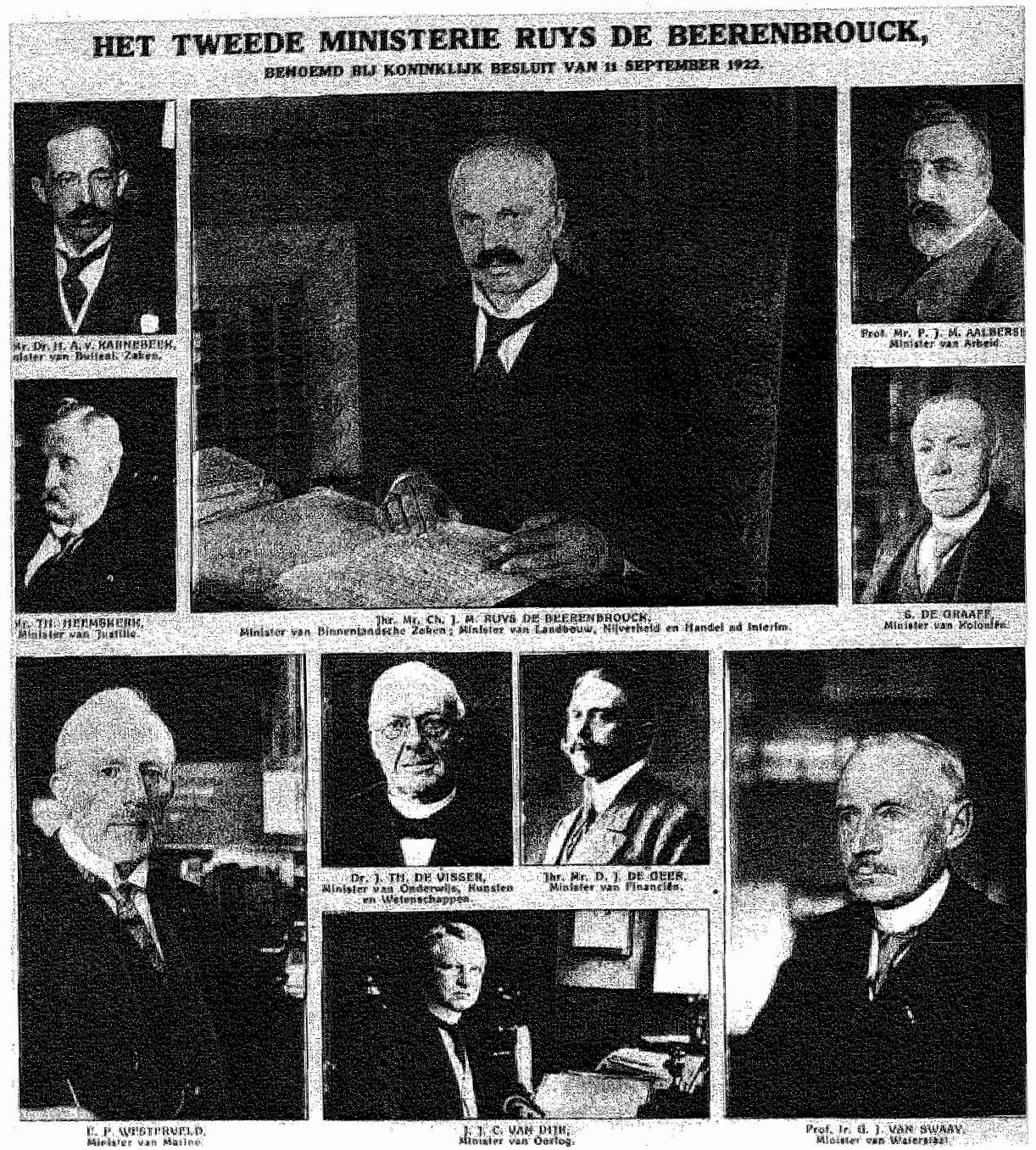

Fotoserle van het tweede kabinet-Ruys in de Katholieke Illustratie van 20 september 1922. 


\section{HET TWEEDE KABINET-RUYS DE BEERENBROUCK (1922-1925)}

\subsection{Inleiding}

Met klein ceremonieel wordt op dinsdag 19 september 1922 de zitting van de Staten-Generaal geopend. De koningin is van 4 tot 20 september op staatsbezoek in Denemarken, Noorwegen en Zweden en in plats van haar troonrede hoort de verenigde vergadering deze "derde dinsdag" de openingsrede van de pas herbenoemde voorzitter van de ministerraad aan.

Pas herbenoemd, maar nog niet beëdigd I Toen Ruys op 11 september de formatie rond had, stelde hij Wilhelmina daarvan meteen door tussenkomst van haar Kabinet op de hoogte. Nog diezelfde dag volgde een in Stockholm getekend koninklijk besluit dat aan alle ministers per 18 september ontslag verleende en aansluitend acht van hen herbenoemde en twee "nieuwe" - Van Swaay en Westerveld - aanstelde.

Vlak vóór de vorstin naar Scandinavië vertrok, stelde formateur Ruys haar voor, lemand te machtigen om de eventueel tijdens haar afwezigheid benoemde ministers te beëdigen. Maar voor Wilhelmina was de grondwetsbepaling in wording: "de eed in handen van de Koning", reeds geldend recht, waarin dat longa manu gedoe niet past.

Eerst op de vierde dag van hun staatsrechtelijk onbevoegde ' ambtsuitoefening leggen de ministers eindelijk de vereiste eed af. In handen van de koningin natuurlijk.

Zo verklaart Ruys dus met een vals startsein op 19 september de zltting van de Staten-Generaal geopend. De zittingsduur van beide kamers zal overigens ongewoon kort zijn. De nleuwe kamers die na de ontbinding van het parlement in verband met de herziening van de grondwet $z \mid j n$ gekozen, kwamen namelijk al in juli bijeen. En volgens de - toenmalige - regeling van de kieswet geldt de laatst voorafgaande derde dinsdag van september als het moment van aanvang van de zitting, zodat, te rekenen van september 1921, de eerstvolgende periodieke verklezing in de zomer van 1925 valt.

Het kabinet, dat bij een reguller verloop van zaken ook een driejarige zit- 
tingsperiode voor de boeg heeft, kent het eerste jaar weinig problemen. Het zet een forse bezuinigingsoperatie in en werkt een druk wetgevingsprogramma af.

In de aanioop naar het tweede zittingsjaar steekt de storm op. Na ontvangst van het advies van de commissie die zich over de vlootkwestie boog, besluit het kabinet er bil de Staten-Generaal op aan te dringen het desbetreffende ontwerp van wet in behandeling te nemen. De Geer kan zich niet verenigen met het kabinetsbesluit, treedt op 11 augustus 1923 af en wordt opgevolgd door Colijn.

Tweeënhalve maand later verwerpt de Tweede Kamer de vlootwet en dient het kabinet zijn ontslag In. Na vijf vergeefse formatiepogingen eindigt de kabinetscrisis begin 1924 met een weigering van de ontslagaanvraag van de ministers.

In de resterende regeerperiode slaagt Colijn erin het financiële everwicht te herstellen. Het zijn vooral de ambtenaren en het onderwijs die daar zwaar voor moeten boeten.

Ruys II: een regeerperiode van wetgevende bloei, van herstel van het financiële evenwicht, maar vooral van de vlootkwestie, die miljoenen $\mathrm{Ne}$ derlanders in haar greep heeft.

Het wordt tijd om over deze jaren wat meer in detail te treden.

\subsection{Bezuinigingspolitiek}

Ingeleid door een hoofdredactioneel memento publiceert De Standaard van 19 september 1922 de rede waarmee Ruys die dag de zitting van de Staten-Generaal opende. In bezielde taal grijpt de nieuwe hoofdredacteur terug op een oude joodse spreuk: "Wie den dageraad heeft gezien, heeft nog niet de schemering aanschouwd". Weldra verschaft hij zijn lezers die deze onbijbelse wijsheid niet vatten, licht in het halfduister.

Hier is niet een hoofdredacteur aan het woord die zich beperkt tot dagbladschrijven, maar een die ook nog de baas is van een partij èn een kamerclub. De drager van deze - antirevolutionaire - tiara heet Colijn, en dat beduidt drievoudig oppassen voor het net aangetreden kabinet!

Vol kommer om de algemeen politieke en financiële toestand van het land, doch zonder kwel om het moeizaam bereikte regeerakkoord, dringt dit eenpersoonsmachtsblok bij de algemene beschouwingen aan op drastische beperking van de defensietaak. Als een plotselinge evenknie van de sociaal- en vrijzinnig-democraten betoogt deze voomalige minister van oorlog op 9 november dat wij niet méér kunnen doen dan onze verplid- 
tingen als lid van de internationale volkerengemeenschap nakomen, maar dan moeten wij wel de gedachte aan een langdurige verdediging van ons nationale grondgebied loslaten. ${ }^{2}$

Dát is nog eens taal naar mijn hart, looft Troelstra, en ook Marchant en vrijheidsbonder Dresselhuys richten warme woorden tot de kersverse ontwapenaar. Nolens en Schokking kunnen hun oren niet geloven, maar zij zijn niet de enigen die menen dat het in Keulen dondert. De fractievergadering van de AR staat eveneens perplex van de uitlatingen van haar voorzitter in de kamer. Er vallen harde woorden. Gebelgd verwijt de club hem eigengereidheid en ontrouw aan de partijlijn. Niet in onze internationale militaire bijdrage, maant Rutgers de zwenkende voorman, maar in de verdediging van ons eigen grondgebied ligt de "morele zenuw" van de dienstplichtwet, die onlangs met de steun van de AR is aangenomen. ${ }^{3}$ Het kabinet heeft vijf dagen de tijd om zijn verbazing over Colijns maidenspeech om te smeden tot een krachtig antwoord. Resoluut verklaart Ruys dat de regering niet wenst te tornen aan de eisen die de omstandigheden en het statuut van de Volkenbond stellen aan de verdediging en de velligheid van het land. Het is mij bekend, vervolgt de premier, dat de geachte afgevaardigde voor de komende jaren een middelendaling van $f 100 \mathrm{ml}$ joen verwacht, die verdergaande bezuinging nodig maakt. Het kabinet staat open voor nadere suggesties van de AR-fractle, mits die maar niet opnleuw neerkomen op ernstige verzwakking van het defensiestelsel ...

Bij de repliek blaast Colijn de terugtocht. $H(i j$ het mes zetten in het operatieleger? Nee, men heeft hem verkeerd begrepen I Alleen het vestingstelsel en andere "dode" weermiddelen - zaken die overigens weinig besparing opleveren -, dié hoeven van hem niet langer intact te blijven. ${ }^{5}$

Op deze wijze maakt Colijn - óók in onberekenbaarheid de ware opvolger van Kuyper - zijn twilfelachtige debuut in de Tweede Kamer. In elk geval maakt zijn optreden één ding duidelijk: het wordt ernst met de bezuiniging! "We kunnen er nog last van krilgen", peinst Ruys.

\section{* Narigheid in het verschiet}

Hoe fors het kabinet ook het mes in de uitgaven voor 1923 zet, toch komt het op 19 september met een begroting die niet sluit.

Zouden aanvankelijk alle ministerles hun uitgaven binnen één jaar minstens $17 \%$ moeten terugdringen, bi] nadere doorrekening van die taakstelling blijkt zo'n afslankingsoperatie aanzienlijk méér tijd te vergen. Een grote tegenvaller voor het kabinet, zeker nu andere bezuinigingsmaatregelen, als een pensioenkorting op de ambtenarensalarissen, niet kunnen goedmaken dat de begroting voor 1923 een reëel tekort van ruim $f 40$ miljoen, ofwel 
$61 / 2 \%$ vertoont.

Ziet het er met de overheidsfinanciën al niet rooskleurig uit, daar komt nog bil dat ook verlieslijdende staatsbedrijven en groeiende werkloosheid het kabinet parten spelen. Kortom, het gaat bergafwaarts met de economie. Deze voorbode van een malaise plaatst de minister van financiën voor de weinig benijdenswaardige taak, over de hele linie ingrijpende bezuinigingen te bewerkstelligen. En dit zware saneringsproces ligt nu midden op het bordje van De Geer, uitgerekend een man die niet zat te popelen om dat ondankbare ambt te aanvaarden en bovendien lemand die als de dood is voor narigheid.

Met zogenaamde "perspectiefbezulnigingen" wil De Geer het begrotingsevenwicht op middellange termijn herstellen. Naast deze voorshands papieren dekking van de tekorten, heeft de bewindsman ook voor de post en het spoor - twee staatsbedrijuen in de rode cijfers - een toekomstgerichte oplossing in petto: hil zegt beide organisaties resultaatverantwoordelijkheid aan - een nog steeds gangbare vorm van mandateren, waarbij de ene ambtenaar de andere tot ondernemingszin poogt te prikkelen.

Van alle ministeries zit onderwijs het meest in de knel. Het bezwijkt haast onder de loden last van de schoolwet 1920, deelt echter gewoon naar rato mee in de integrale rijksversoberingsslag en raakt bovendien nog de jaarlijkse tegemoetkoming in het automatische accres van zijn uitgaven kwijt.

Een ministerie overigens met een begroting van ruim $f 150$ miljoen. En dus, zo redeneert De Geer, als er één ministerie is waar de bezuinigingsoperatie een testcase voor mijn saneringsbeleid kan zijn, is het onderwijs wel.

De Visser stelt hem niet teleur. Een technische herziening van de schodwet maakt de klassen groter, de drempel voor oprichting van bijzondere scholen hoger en geeft het bevoegde gezag de ruimte om openbare scholen tot een "genoegzaam aantal" te verlagen.

Een goed voorbeeld doet goed volgen. Onder de strenge tucht van de schatkistbewaarder brengen ook de andere ministeries hun financiële offers. Komt daar in februarl 1923 Aalberse opeens $f 2$ miljoen extra vragen voor de werklozensteun !

De Geer houdt voet bil stuk. Aalberse - altijd meteen op hoge poten als hij zijn zin niet krijgt - wil er prompt mee kappen: "lk bedank er feestelijk voor, om de zetbaas van Financiën aan het Ministerie van Arbeid, Handel en Nijverheid te zijn." ${ }^{7}$ Ruys hakt de knoop door: de extra steun komt er. Als men mijn saneringsbeleid nóg eens zo onderuithaalt, ben $/ k$ degene die er feestelijk voor bedankt. De getergde minister van financiën zou niet lang 
op de volgende krachtproef hoeven te wachten ...

De vlootwet ! Men herinnert zich dat de formatie op het laatste moment bijna stukliep op dit onderdeel van het regeerakkoord. Tot verbijstering van Ruys was De Geer eerst nlet te porren voor de portefeuille van financiën als het vlootplan bleef zoals het was. Tòch tekende de demissionaire minister bij toen de formateur hem verzekerde dat een staatscommissie het plan nog eens terdege op zijn financiële merites zou beoordelen, zodat het tot zolang geenszins vaststond waar dit alles op zou uitdraaien.

Eind maart 1923 verschijnt het rapport van de staatscommissie. Wat kan dit gezelschap met zijn mission impossible - het onderzoeken van het tempo van aanbouw van de vloot die in alle geval over zes jaar van stapel moet lopen - anders dan tot het oordeel komen "dat de Regeering niet mag aarzelen te doen wat in haar vermogen is om de aanneming en de dadelijke uitvoering van de Vlootwet te verzekeren." ${ }^{8}$ ?

Voor de ministerraad is daarmee de kous af. Met uitzondering van De Geer, die zljin aan Ruys bekende bezwaar tegen de enorme lasten van de vlootwet handhaaft en aftreedt.

Vrijwel alle collega's nemen hem zijn vaandelvlucht hoogst kwalijk. Behalve Ruys, die er op staat de oud-minister te danken "... voor de loyale en prettige wijze, waarop gij mij in de afgeloopen twee jaren zijt tegemoet getreden ..." 9 Een uiting van een knagend geweten van de premier ?

We laten de bezuinigingsoperatie en de vlootkwestie even rusten en stappen nu over op de wetgevingsarbeid van het kabinet.

\subsection{Een kindsdeel en nog veel meer}

Het was midden in de formatiedrukte van 1922 dat Ruys even de tijd nam om een gewaardeerde collega geluk te wensen met dlens zeventigste verjaardag. De formateur ging niet met lege handen op pad. Met een amicaal binnenkomertje: "Je zoudt niet graag hebben, dat ik le deur voorbijging" ${ }^{10}$, meldde de bezoeker zich bij de jarige om hem opnieuw de portefeuille van justitie aan te bieden.

Feesteling Heemskerk is er maar wat blij mee dat hij op de leeftijd der sterken nog steeds in tel is. Eerder was hi] al eens fractieleider van de AR in de Tweede Kamer, toen vijf jaar premier, vervolgens lid van de Raad van State en dan vier jaar politieke baas van het justitieapparaat.

Een all-round bestuurder dus, scherpzinnig en gouvernementeel, een vaardige, soms zelfs snaakse debater, een toeverlaat bovendien, al komt dit 
laatste onverzoenlijke partilgenoten nooit meer over de lippen sinds hij het bestond Kuyper in 1908-1909 de pas naar een tweede premierschap af te snijden ...

Ja, Theodoor Heemskerk kan bogen op een geslaagde carrière, bijna net zo imposant als die van zijn vader lan, de "conservatief zonder partij" ", op wiens naam liefst drie kabinetten - tussen 1866 en 1888 - staan.

Formateur Ruys weet wat hil aan Heemskerk heeft. Het nieuwe kabinet moet straks een aantal lastige wetten door het parlement loodsen en bij die oude rot in het vak is dat in goede handen.

Kan de formateur na de verjaardagsvisite rekenen op de kennis, ervaring en loyale steun van Heemskerk, naderhand op voortgangsrapport in Het Loo treft hem de sceptische vraag: "Houdt $\mathrm{U}$ mr. Heemskerk nu niet uit medelijen ?"12

Alemachtig, wat een vraag, over een oud-premier notabene! Wel ooit goed om Hare Majesteit te verlossen van die "... machtsbeluste Kuyper, ... Misschien ... te jolig of te gereformeerd of te zeer allebei ..." ${ }^{13}$, maar zou zo lemand niet deugen voor justitie? Nee, dat gaat ook de sceptica bi) nader inzien te ver !

\section{* Leven en laten leven}

$\mathrm{Al}$ in de eerste maanden van zijn tweede ambtsperiode als minister van justitie brengt Heemskerk de levensverzekeringswet tot stand. Deze zeer uitvoerige wet van 1922 (Staatsblad nr. 716) stelt de levensverzekeraar, met behoud van de vrijheid van bedrijf, onder het toezicht van een overheidsinstelling, de Verzekeringskamer.

Gezonde gezinspolitiek komt tot uitdrukking in het wetsontwerp tot wijziging van het erfrecht, waarmee Heemskerk de positie van de langstlevende echtgenoot wil versterken.

Volgens de tot dan toe geldende regeling van het Burgerlijk Wetboek kwam de echtgenoot pas als wettig erfgenaam aan bod wanneer de overledene geen famille tot en met de twaalfde graad naliet.

De huwelijkspartner was in dit stelsel een vreemde eend in de bijt, een opvatting naar de trant van - si fabula vera - een Twentse boer die, net terug van de begrafenis van zljn wederhelft uit Drente, het kroost opmontert met: "Zlezo, jongens, nu zijn we weer onder elkaar." 14

Het ontwerp van de minister stelt de echtgenoot voor de opvolging bij versterf op één lijn met een wettig kind. In het parlement krijgt Heemskerk brede steun voor zijn standpunt dat het familiebelang maar wat moet inschikken voor het gezinsbelang. Het nieuwe stelsel, dat op 17 februari 
1923 het Staatsblad (nr. 40) haalt, kent de langstlevende echtgenoot een kindsdeel toe, maar laat deze tegelijkertijd wèl voelen wat het betekent ouder te zijn.

\section{* Beklaagde promoveert tot verdachte}

Net als het erfrecht van de echtgenoot liepen ook het strafproces en het zeerecht lange tijd ver achter bij de maatschappelijke ontwikkelingen.

Toen de invoering van het Wetboek van Strafrecht in 1886 een afgehele herziening van de strafvordering nodig maakte, zat er nog steeds geen beweging in de hercodificatie van het Wetboek van Strafvordering van 1838 , dat stamde uit Frans recht anno 1811 en derhalve nogal gedateerd mocht heten.

Het strafproces had een sterk Inquisitoir karakter, wat inhield dat de beklaagde, zoals de verdlachte toen heette, zeer weinig rechten had. Met name in het stadium van het voorbereidende onderzoek was hil slechts lijdend voorwerp, zonder enige rechtsbijstand. Nadat in de laatste decennia van de negentiende eeuw diverse malen vergeefs was geprobeerd het inquisitoire strafproces door een meer accusatoire procedure te vervangen en zo van de nagenoeg rechteloze beklaagde een verdachte zonder rechtsnood te maken, gaf het kabinet-Th. Heemskerk in 1910 een staatscommissie de opdracht een geheel nieuw wetboek van strafvordering te ontwerpen.

Met dat besluit zou Heemskerk nog niet van die taaie materie af zijn! De staatscommissie had namelijk drie jaar nodig om haar werk te voltoolen. Vervolgens verstreek een jaar eer de regering het gematigd accusatoire ontwerp van de commissie overnam en dit bij de Tweede Kamer indiende. Toen was het vier jaar wachten op het voorlopige verslag van de commissie van voorbereiding in de Tweede Kamer, die het ontwerp niet accusatoir genoeg achtte zolang het de verdachte niet nadrukkelliker als procespartij aanmerkte. Bij memorie van antwoord nam de regering het kruisverhoor in het ontwerp op en kwamen voorts ook extra garantles voor de verdachte en uitbreiding van de bevoegdheden van de verdediging in het voorbereidende onderzoek een eind tegemoet aan de wensen van de kamer. ${ }^{15}$

Intussen was het voorjaar 1918 geworden en naderde het kabinet-Cort van der Linden het tijdstip van zijn aflossing. Heemskerk nam de estafette weldra over van $\mathrm{mr}$. B. Ort - die vóór zijn ministerschap voorzitter van de bewuste staatscommissie was geweest - en schrapte bij nota van wi|zigingen het kruisverhoor weer uit het ontwerp. De herziening van het wetboek van strafvordering stelt eigenlijk niet veel bijzonders voor, biechtte 
Heemskerk bij ziln verdediging van het ontwerp in het parlement eerlijk op. Met die bekentenis trof de minister blljkbaar de juiste toon om de verdeelde gemoederen in beide kamers massaal bijeen te brengen. Het half inquisitoire, half accusatoire Wetboek van Strafvordering bereikte vervolgens op 15 januari 1921 het Staatsblad (nr. 14).

Maar zelfs dán laat de strafvordering Heemskerk niet los. Er is nog een hoop voorbereidend werk te doen aan de invoering van het nieuwe wetboek en ook voor dat karwel huurde Ruys hem opnieuw in. Het duurt tot 29 juni 1925 voordat de oude meester zijn invoeringswet tot een goed eind brengt, net vóór de afloop van zijn tweede - en laatste - ambtsperiode als minister van justitle. Colijn is aan het bewind, met Schokking op justitie, als het wetboek op 1 januari 1926 in werking treedt.

Onder de verantwoordelijkheid van Heemskerk komt bij wet van 22 december 1924, Staatsblad nr. 573, ook een nieuw zeerecht tot stand.

De wet - die onder meer bepalingen over zeeschepen, vervrachting, vervoer en aanvaring bevat en de reder de centrale plaats in de zeevaart toewijst - Is een monument ter herinnering aan Willem Molengraaff (18581931), die van 1885 tot 1917 hoogleraar handelsrecht in Utrecht was. Daartoe in 1905 door de regering uitgenodigd, ontwierp Molengraaff twee jaar later een nieuw zeerecht, dat de grondslag vormde voor het in 1920 bij de Tweede Kamer ingediende regeringsontwerp en de in 1924 aangenomen wet.

De invoering van het nieuwe zeerecht laat echter nog tot 1 februari 1927 op zich wachten. Op 25 augustus 1924 is namelijk aan de conferentietafel in Brussel - een vervolg op de maritieme conferentie van 1921 in Den Haag - een internationaal akkoord bereikt over de aansprakelijkheidsregeling bil zeevervoer. En Nederland moet nu die zogenaamde Hague Rules wel eerst in het nieuwe zeerecht incorporeren, wil het in het internationale zeevervoer niet uit de boot vallen.

\section{* De weg naar arbeidsvrede}

De arbeidsgeschillenwet van 4 mel 1923, Staatsblad nr. 182, vormt het sluitstuk van het sociale bouwwerk dat onder het bewind van Aalberse tot stand komt. De consensusgedachte waarvan deze wet uitgaat, maakt haar tot een nieuw fenomeen in het wettelijke arbeidsrecht.

Tot grote schade van de economie gingen in het begin van de jaren twintig zo'n acht milljoen werkdagen verloren als gevolg van stakingen en uitsluitingen.

Zonder dergelijke arbeldsconflicten op de spits te drijven door verbods- 
bepalingen, will de wet van 1923 een dam opwerpen tegen de zorgbarende onrust op het arbeidsfront. De rijksbemiddelaar - een nieuw instituut moet bij een dreigend of reeds ontstaan arbeldsconflict de ruziënde partlien om de tafel zien te kriggen om hen ertoe te bewegen het geschll min= nelijk te schikken of door arbltrage te beslechten. Pas als de bemiddelings: poging mislukt en het algemeen belang door het uitblijven van consensus in het gedrang dreigt te komen, kan de minister ingrijpen en een enquête doen instellen naar de achtergronden van het arbeidsconflict.

De Tweede Kamer heeft in grote meerderheid weinig moeite met het wetsontwerp. Wel laat Schaper namens zijn fractie weten geen enkele inbreuk op het stakingsrecht te dulden. Maar het feit dat " ... de vakverenigingen uitgeput raken, vooral ook hun kassen ..." ".6. geeft voor de soclaal-democraten de doorslag om óók met het voorstel mee te gaan.

Vinden binnengekomen protesten van werkgevers tegen het enquêterecht

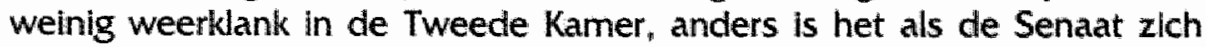
over het wetsontwerp buigt. Bij nadere reflectle biliken elf senatoren - tien rechtsen en de enige vrijheidsbonder - gevoelig voor de werkgevers-lobby en wijzen de onderhavige enquête, die immers ook mag neuzen in de boeken van een onderneming, als een schending van het beroeps- en bedrilfsgeheim af.

"Ik ben nog noolt zo woedend geweest en heb nog noolt zo gefoeterd..." ${ }^{17}$, schrijft Aalberse over het moment dat vijf partilgenoten hem in de Eerste Kamer lieten zalken. De gedreven minister van arbeid ten voeten uit !

De arbeidsgeschillenwet treedt op 16 april 1924 in werking. Zij is een verrijking van het arbeidsrecht, die - dankzij het gezag dat het instituut van rijksbemiddelaars zich gaandeweg verwerft - " ... het euvel van staking en uitsluiting in de laatste jaren vóór 1940 tot ongedacht kleine afmetingen [terugbrengt]." 18

Het belang van de landbouw wint veld

Een nieuwe regeling van het jachtrecht geeft in 1923 de aanzet tot een bescheiden - hervorming op het gebied van het landgebrulk. De jachtwet van 2 julli 1923, Staatsblad $\mathrm{nr}$. 331, waaraan Ruys als minister van landbouw zijn naam verbindt, haalt een streep door de heerlijke jachtrechten, die zich tot dusver als een feodaal overblijfsel onder de hoede van het Burgerlijk Wetboek wisten te handhaven.

Voorts wil de nieuwe wet het genot van de jacht toekennen aan de pachter in plaats van aan de eigenaar van de grond. Maar als de Tweede Kamer daar een stokje voor steekt, is het voor de pachtboer gewoon weer 
afnokken geblazen als de bloot-eigenaar in jagerstenue verschijnt.

Heeft de landbouw dus maar weinig baat bij de jachtwet, het belang van die sector staat wèl voorop in Ruys" ruilverkavelingswet van 31 oktober 1924, Staatsblad $\mathrm{nr} .481$, die tot doel heeft de landbouwstructuur door herverkaveling van cultuurgrond te verbeteren.

\section{* Organleke regellingen}

Tot driemaal toe komt de gewone wetgever in opdracht van de hoogste wetgever in actie. De nadere uitwerking van de in 1922 in de grondwet opgenomen bepalingen inzake het evenredige kiesstelsel voor de Eerste Kamer, de gewetensbezwaren tegen militaire dienst en het bestuur van de overzeese gebleden, krijgt haar beslag in de kieswet, de dienstweigeringswet en de wet op de staatsinrichting van Nederlands-Indië.

De verdediging van de nieuwe klesregeling voor de Eerste Kamer is een makkie voor Ruys. Links houdt zich opvallend koest, want - thans met acht zetels sterk ondervertegenwoordigd in de Senaat - heeft het er alle belang bif dat het evenredigheidsstelsel in werking is als over drie maanden, in september 1923, de nieuwe Eerste Kamer wordt gekozen. Rechts vindt het jammer dat het ontwerp de elf provincies in electoraal opzicht samensmelt tot vier kiescolleges, waardoor de gedachte aan een afzonderlijke vertegenwoordliging per provincle nagenoeg in rook opgaat.

Ruys herinnert zich dat zijn hooggeleerde vriend Struycken over het nieuwe kiesstelsel in termen van een hoog bèta-gehalte spreekt: "... een merkwaardig product van mathematisch-politische wijsheid - of moet men zeggen onwijsheid ?", en maant rechts voorzichtig om te gaan met deze "buitengewoon moeilijke materie". ${ }^{19}$ Die zachte aandrang doet ook de rechterzijde ervan afzien het mes in het wetsvoorstel te zetten.

Geheel conform het ontwerp verschijnt alzo de herziening van de kieswet op 23 junl 1923 in het Staatsblad, nr. 294.

De dienstweigeringswet van 13 juli 1923 (Staatsblad nr. 357) erkent geen andere grond voor afwiljzing van de krijgsdienst dan het gewetensbezwaar dat lemand verbjedt "een evenmens te doden, ook wanneer dit ingevolge overheidsbevel geschiedt".

De wet hanteert een godsdienstig bepaalde maatstaf die zich niet leent voor een zuivere beoordeling van de bezwaren van een "ongelovige" dlenstweigeraar. Of tòch?

Bij de verdediging van het wetsontwerp komt Heemskerk - na een fundamentele bespiegeling omtrent de vraag: "heeft een ongelovige een geweten ?" - tot de conclusie dat ook deze - bij Gods gratie - besef heeft van 
goed en kwaad, hetgeen hem in staat stelt - onbewust wellswaar - in de geest van de geboden te handelen.

Waarlijk, hier geeft de zeventig-plusser nog eens een acrobatentoer van de bovenste plank ten beste. Dít is pas - naar luid van de openingsclausule van het regeerakkoord: "Christelijke politiek in overeenstemming met de beginselen der Rechterzijde", die korte metten maakt met ongeloof !

Nederland heeft tegenover de bevolking van Indiè een zedelijke roeping te vervullen, klonk het opwekkend in een aan het "wingewest" gewijde passage van de troonrede van 1901 .

Exploitatiepolitiek maakt plaats voor ethische politiek, die overigens niet tot ingrijpende bestuurlijke hervorming leidt.

De wet op de staatsinrichting van Nederlands-Indië van 23 Junl 1925 laat de inwendige aangelegenheden van Indië - voorzover deze niet de aan Den Haag voorbehouden regeling van het Indische staatsbestel en van enkele belangrijke financieel-economische zaken betreffen - over aan "aldaar gevestigde organen", te weten: de door de Kroon benoemde gouverneur-generaal, die het algemene bestuur voert, en de Volksraad, een in 1916 opgericht en uit een Nederlandse meerderheid bestaand adviesorgaan van de gouverneur-generaal op het terrein van regelgeving.

Het regeringsontwerp, verdedigd door minister $\mathrm{S}$. de Graaff van koloniën, beschouwt de gouverneur-generaal als een zelfstandig bestuursorgaan. Maar cle Tweede Kamer voelt niets voor een gouverneur-generaal die zich met zijn ZBO-status in Indië als een vrijgevochten "onderkoning" kan gedragen en legt bij amendement in de wet vast dat deze bestuurder zich naar "koninklijke aanwijzingen" dient te schikken.

Zo brengt het parlement deze overzeese autoriteit in een "tweeslachtige positie; enerzijds is hij zelfstandig, op eigen naam bevoegdheden uitoefenende; anderzijds is hij onzelfstandig, namelijk in een hiërarchische relatie staande tot de minister." 20

Al bil al draagt de nleuwe wet de kenmerken van een strak beteugelde bestuurlijke hervormingsdrang.

Met voldoening kan het kabinet terugblikken op de resultaten van zijn wetgevende arbeid in de jaren 1922-1925. Op velerlel gebied kwamen in die periode regelingen tot stand die - op de Indische staatsinrichting na vele decennia trotseren.

Op een enkel onderdeel van het lijvige wetgevingsprogram blijft evenwel alles bij het oude. Zodra het kabinet zich op het doornige pad van de ethische beginselen waagt, laat het parlement het afweten en stokt de wetgevingsmachine. Dan vormen voorstellen tot - gematigde - aanpassing 
van de zedelijkheidswetgeving op het punt van de "zondag", de lijkbezorging en de filmkeuring, alsmede het ontwerp tot afschaffing van de staatsloterij, een onoverkomelijke hindernis voor links èn rechts: voor de een ligt in die gevallen de springlat te hoog, voor de ander te laag.

Een dergelijke beginselenstrijd doet zich ook voor als de verdediging en de veiligheid van Indië aan de orde zijn. Hier komt de zedelijke roeping van Nederland jegens Insulinde en zijn bevolking in botsing met het belang van een sluitende begroting in het moederland. En in dit politieke dilemma zijn het uiteindelijk de harde eisen van de schatkist die de inmiddels vervazgde echo van het ethische reveil uit 1901 volledig overstemmen.

We pakken nu de draad weer op bij het begin van het zittingsjaar 19231924.

\subsection{De eerste schermutselingen}

De kamers zljn net op reces als een communiqué van de ministerraad op 18 juli 1923 een steen in de politieke vijver gooit. Het kabinet, zo luidt het officieel, zal er bij het parlement op aandringen, aanstaand najaar onverwijld de vlootwet in behandeling te nemen, met de bedoeling haar op 1 januari 1924 in werking te doen treden.

Draagt de heropvoering van het door velen hoopvol afgeschreven vloottreurspel al niet bij tot een rimpelloos vakantiegevoel, na de aansluitende bekendmaking van de ontslagaanvraag van De Geer is het met het rustige sfeertje helemaal gedaan.

Het bericht over de crisis op financiën komt als een volslagen verrassing. Juist op het moment dat het kabinet alle krachten in de strijd moet gooien om het vlootplan én ingrijpende bezuinigingsmaatregelen voor elkaar te brengen, verliest het zijn spll waar de hele financiële huishouding om draalt.

Terwill men alom twilfelt aan het voortbestaan van het kabinet, is Ruys manmoedig op zoek naar een nieuwe spelbepaler op het middenveld. Het was een akelig lege reservebank die de premier vorig jaar tijdens de formatie van zljn ministersploeg aantrof. En dat maakt het toch een beetje merkwaardlg dat hij in deze tijd waarin de financlën van allesoverheersende betekenis zijn, niet zèlf "de koorden van de schatkist" in handen neemt.

De Geer bijvoorbeeld is de informateur in 1922 en de formateur in latere Jaren, die van geen premierschap zonder de post financiën wil weten. Kuyper, die ook graag altijd de touwtjes in handen had, vond daarentegen 
zo'n combinatie van ambten in zijn tijd helemaal niet nodig: "... laat de premier gaan zitten op dien zetel vanwaar het beslissende woord ter oplossing van de politieke problemen van het oogenblik moet gesproken worden." 21

Toen tijdlens de formatie van 1922 de vraag rees of het wenselijk is het premierschap met de post financiën te combineren, waren Ruys en Nolens unaniem van mening dat het financiële belang beter tot zijn recht komt als de functies gescheiden zouden blijven. ${ }^{22}$ Bovendien zou een niet met financiën belast premierschap Ruys bij zijn eventuele herbenoeming de nodige manoeuvreerruimte geven die hij als bemiddelaar bij uitstek. zeker naar zijn vaak overvragende wapenbroeder Aalberse toe, goed kon gebruiken. En dit laatste is in 1923 nog niet anders !

Ruys" kijk op de vervulling van de vacature op financiën brengt met zich mee dat hij iemand moet zien te vinden die achter het vlootplan staat én een krachtig bezuinigingsbeleid kan voeren.

Aan dit profiel voldoet als geen ander de schrijver van het hoofdartlkel in De Standaard van 19 jull 1923: "... de uitgaven van ons Staatsbudget [moeten] nog met een goede 100 millioen per jaar omlaag .... [en] als er 100 gevonden moeten worden, zijn er ook 101 te vinden. Want om meer dan één millioen per jaar gaat het bil de Vlootwet niet." 23

En precies op deze scribent laat Ruys zijn oog vallen. De uitverkorene Colijn natuurlijk - tast echter niet gretig toe: hij wil eerst zwart op wit dat hil zijn gang kan gaan. De begroting dient vóór de Kamerverkiezing van 1925 weer sluitend te zijn. Elk ministerie moet daartoe een reële bezuinging van $10 \%$ aanvaarden. Oók de milltaire departementen, maar vanwege het vlootplan wil de redder in nood marine wel ontzien, alleen krilgt ooriog dan gewoon een dubbele aanslag.

Met dit dictaat in handen gaat Ruys vervolgens de ministerraad in. Van Dijk van oorlog steigert, Aalberse en De Visser zien de bul al hangen, van armoe is Heemskerk alvast bezig posten te schrappen, maar hoe pljnlijk het bezuinigingsplan ook is, een kabinetscrisis will de vergadering, Ruys voorop, koste wat kost voorkomen.

Op 7 augustus stelt Ruys de schrlftelijke akkoordverklaring van het kabinet keurig op een dienblad aan Colijn ter hand. Vier dagen later meldt de dominante aanwinst zich op zijn post aan de Kneuterdijk. "Zelden had een minister van financiën", concludeert Puchinger," bij zijn optreden het heft zo stevig in handen gekregen als Colijn in augustus 1923." 24 


\section{* De sterke man in actie}

De eerste de beste miljoenennota van Colijn veroorzaakt direct al grote beroering in en buiten het parlement. Zijn bezuinigingsmaatregelen tot een hoogte van $f 140$ miljoen liegen er dan ook niet om. Als dekking van het tekort van $f 100$ miljoen op de gewone begroting van 1924, vermeerderd met te verwachten nieuwe uitgaven ad $f \mathbf{4 0}$ miljoen, wijst de minister aan een besparing van $f 60$ miljoen op de salarissen van ambtenaren en leerkrachten, van $f 50$ miljoen op de rijksdienst, alsmede een verhoging van indirecte belastingen met $f 30$ miljoen.

Tijdens de voorbehandeling van de miljoenennota in de ministerraad van 11 september voorzag Aalberse fel verzet tegen de bezuinigingen, met alle gevolgen voor vlootwet en kabinet van dien. Maar "'t ongelukkige is dat je in den Ministerraad bij die dingen altijd alleen staat.", noteerde ${ }^{25}$ de miskende profeet, die beter verdiende...

Hoe gespannen de stemming in de Tweede Kamer is, blijkt dadelijk na de opening van de nieuwe zittingsperiode uit een procedurekwestie. Zonneklaar op consigne van het kabinet stelt kamervoorzitter $\mathrm{mr}$. D. Koolen (RKSP) op 20 september voor, eerst de vlootwet en daarna de staatsbegroting in behandeling te nemen.

In het hlerop volgende ordedebat ageert de oppositie fel tegen de voorgestelde behandelingsvolgorde, omdat deze de kamer niet de kans biedt het vlootplan tegen het licht van de begroting en het aftreden van De Geer te houden.

De rechterzijde bewaart intussen een beklemmend stilzwilgen over die alleszins redellike bezwaren tegen het plan van de voorzitter. Onbedoeld helpt Troelstra door zijn aankondiging van een interpellatie over de recente ministerscrisis de kamerpresident - en stellig ook de regeringsfracties - ult de problemen: indien de kamer de soclaal-democraat laat begaan, is de voorzitter bereld de interpellatle vóór de behandeling van de vlootwet op de agenda te plaatsen. Aldus geschledt, en zo kan Troelstra op 11 oktober gaan vissen naar de verborgen roerselen van De Geer.

Het interpellatiedebat brengt weinig nieuws over de reden van het vertrek van de minister boven water. Ruys benadrukt het belang om "... onze verplichtingen als zelfstandige Staat, vooral in Oost-Azië, op eenigszins voldoende wijze te vervullen ... De heer de Geer daarentegen stond op het standpunt, dat de staat onzer financiën de invoering van een dergelijke [vloot-]wet nlet gedoogde, dat vastlegging door de wet van zekere manine-uitgaven niet toelaatbaar was ..." ${ }^{26}$ Colijn voegt daar nog aan toe dat de vlootwet de jaarlijkse uitgaven op de Nederlandse begroting niet of 
nauwelijks zal verzwaren. Maar Troelstra hecht geen waarde aan de woorden van de nleuwe bewindsman. Voor hem is Colijn immers een representant van "bepaalde grootkapitalistlsche Indische kringen", een "sterke man" die fors wil bezuinigen en tegelijkertijd de vlootwet doordrijft, een persoon zonder het "morele gezag" van zijn voorganger. ${ }^{27} \mathrm{Zeg}$ maar gerust: de Nederlandse varlant van Mussolini, vat de communist dr. W. van Ravesteilin brutaalweg samen. 28

De toon is gezet. De kamer heeft nu haar kick voor het aanstaande vlootdebat.

\subsection{Nolens en zijn rebellenclub}

68 van de 100 kaarten zijn al geschud als de Tweede Kamer op 16 oktober aan het vlootdebat begint. De complete linkerzijde is vooraf even vastberaden van plan op het bod van het kabinet te passen als de drie protestantse fracties van zins zijn het te steunen.

Het ontbrekende stel kaarten is in handen van de ernstig verdeelde katholieke fractie, hetgeen de kamer belet het bod als een spelletje voor de bühne af te roffelen.

In de katholieke kamerclub is onweer aan de lucht. Tijdens de fractievergadering van 12 oktober krijgt Nolens de wind van voren. De monseigneur had toch anderhalf jaar geleden de vlootwet zo "prachtig van de baan gewerkt" 29 , en daarna zou een staatscommissie daar voorgoed mee afrekenen ? Vervolgens hoort de kamerclub er nooit meer iets van. En nú beweert de fractielelder opeens dat de binding aan het regeerakkoord óók het vlootplan omvat !

Het zijn niet alleen lastige "jongere heeren" die Nolens de voet dwars zetten. Ook Sophie Bronsveld-Vitringa - van huis uit hervormd, later overgegaan tot de "alleenzaligmakende kerk", zoals Oud met zich toegeèigende kennis des onderscheids poneert ${ }^{30}$ - en de notoir tegendraadse Haarlemmer Bomans - "de vader van ..." - roeren zich nogal in de discussie.

De meest geduchte kritlek levert Van Schaik. De Bredase jurist Joseph van Schalk (1882-1962) is in de zes jaar van zijn verblijf in de kamer uitgegroeid tot een vooraanstaand, kalm beraden politicus. Hil brengt het straks driemaal tot voorzitter van de Tweede Kamer en even vaak tot minister. Maar eerst speelt hi] nog een hoofdrol in het vlootdrama.

Van Schalk verwijt Nolens dat deze als vaste klant in het Torentje de fractie niet heeft gewaarschuwd dat het kabinet overwoog de vlootwet weer aanhangig te maken. En wat het dubbel zo erg maakt, is dat hil als fractieleider goed weet dat de kamerclub niet bereid: is een wet die het zeede- 
fenslebeleid voor jaren vastlegt, voetstoots te aanvaarden.

In de bijeenkomst van de kamerclub van 17 oktober doet Nolens een vertwijfelde poging om de "rebellen" in het gareel te brengen. Wie de vlootwet verwerpt, stelt het kabinet en de coalitie in de waagschaal, want in het regeerakkoord van 1922 ligt "een zekere gebondenheid van ons ten opzichte van het wetsontwerp". ${ }^{31}$

Nee, ècht in vorm is de voorzitter vandaag niet, en zo'n tien fractieleden blijven dan ook Oostindisch doof voor alle vermaningen. Een eenvoudig rekensommetje wijst uit dat de vlootwet aan een zijden draadje hangt.

De kamerbehandeling van de vlootwet loopt uit op een tiendaags marathondebat waarin zich liefst 34 afgevaardigden en vijf ministers mengen. Met spanning volgt men ook buiten het kamergebouw het verloop van de beraadslagingen. Hoe sterk dit onderwerp leeft, blijkt onder meer uit een aan het parlement gerichte petitie waarin 1,3 miljoen Nederlanders aandringen op verwerping van de wet.

De sprekers van links hameren afwisselend op het aambeeld van de algehele ontwapening, de onaanvaardbare geldsmijterij of een combinatie van beide. Voor het protestantse deel van de rechterzijde is het een uitgemaakte zaak dat een vloot die onze neutraliteit handhaaft, tegelijkertijd het nationale en internationale belang van vrede en recht dient. Zonder twijfel allemaal boelende, zij het ook een tikkeltje voorspelbare standpunten, maar waar iedereen ongeduldig naar uitkjjkt, is wat Van Schaik, Nolens èn het kabinet te vertellen hebben I

Op 18 oktober komt Van Schaik aan de beurt. De spreker deelt de mening van de regering dat "... een vloot zoowel in Nederland als in Nederlandsch-Indië ter handhaving en verdediging van onze neutraliteit op dit oogenblik nog niet kan worden gemist." Uit staatsrechteliik en financieel oogpunt is voor hem moeilijk te accepteren dat "... bij deze wet aan de Regering een soort onherroepelijke volmacht [wordt] verleend ... [waardoor] het marinebeleid in ganschen omvang gedurende verscheidene jaren bevroren zal zijn ... Tast lk mis, door aan te nemen, dat door deze wet de Staten-Generaal ten aanzien der marine factis van hun jaarlijksch budgetrecht afstand doen en een 6-jarige begrooting aannemen ?" 32 la, "... dat er bij mil weinig geestdrift bestaat voor de vlootplannen en andere defensleplannen, ik zal het niet ontkennen ..."., geeft Nolens royaal en ten overvloede toe, maar "... dat binden is inhaerent aan leder plan, ... [evenwel zijn] noch het plan, noch den duur ... mathematische grootheden, maar ... gegevens, die veranderen bij een wezenlijke verandering in de omstandigheden ..." 33

Dat er zlch politieke en financiële omstandigheden kunnen voordoen die 
dwingen tot aanpassing van het vlootplan, dáárover verschillen Van Schalk en Nolens niet van mening. Maar op Van Schaiks vraag waarom men zich dan bij voorbaat voor zes jaar aan zo'n bij de wet vastgelegd plan zou moeten binden, heeft Nolens zijn kennis van het vlootakkoord even niet paraat.

Het antwoord is dus aan het kabinet. Ruys geeft aan dat een groot deel van de vloot is "opgevaren". De alarmerende toestand van de marine maakt het noodzakelijk volgens een vast en financleel hecht plan een kleine maar goed toegeruste vloot te bouwen. Onder wettelijke garantie, "... omdat géén vlootwet op den duur zou leiden tot geen behoorlijke vloot..." ${ }^{34}$

\section{* Een krachteloos machtswoord}

$\mathrm{Na}$ afloop van de kamerzitting van 18 oktober komt de katholieke fractie weer bijeen. Er is veel waardering voor de correct-zakelijke rede die Van Schaik zoëven in de kamer uitsprak. Daar stelde Nolens maar een zwak weerwoord tegenover, dat geen indruk maakt op de "rebellen".

Ogenblikkelijk brengt Nolens het bericht van het naderende onhell over aan Ruys. De premier trekt prompt aan de bel bij Aalberse: als Píet nou eens zou proberen de drie rebelse vakbondsvertegenwoordigers in de fractie op de ernstige sociale gevolgen van de val van dit kabinet te wil]zen... ${ }^{35}$

In het kabinetsberaad op 23 oktober hebben Ruys en Aalberse hun collega's geen goed nieuws te melden. De RK kamerclub telt tien dissidenten, onder wie ook de drie uit de arbeidersbeweging, die - Aalberse ten spijt niet te winnen zijn voor een combinatie van vlootwet én drastische bezulnigingen. Zoals de situatie thans ligt, gaat de vlootwet bij de stemming in de kamer met 50 tegen 50 ten onder. Tenzil een laatste waarschuwing van het kabinet aan het adres van de roomse afvalligen alsnog een wonder verricht.

Een dag later verkJaart Ruys in de kamer: "... dat het Kabinet in zijn geheel en ieder zijner leden individueel, gelet op de groote beteekenis van het wetsontwerp ... bij afstemming de verantwoordelijkheid voor het bestuur van 's Lands zaken niet zouden kunnen dragen. Immers wordt dat [ontwerp] verworpen, blijven wij in den chaotischen toestand van het oogenblik, dan bestaat niet de minste waarborg, dat dit plan ooit zal worden verwezenlijkt." 36

Het machtswoord van het kabinet mag niet baten. Met uitzondering van een ernstig ziek lid van de CHU-fractie zijn alle leden aanwezig als op vrijdag 26 oktober de eindstemming plaatsvindt over het zozeer omstre- 
den vlootontwerp. De publieke tribune is propvol en op het Binnenhof staan de mensen in drommen op de uitslag te wachten.

Meteen na de bekendmaking van het eindresultaat - 50 stemmen tegen, 49 stemmen vóór - heffen de socialisten de Internationale aan en klinkt buiten ultbundig gejuich. Terwill de ministers in dit helse lawaal hun boeltje pakken ventileert Marchant, ondanks het spektakel duidelijk hoorbaar: "Goddank, we ziln ze kwijt". ${ }^{37}$ Troostend zegt Ruys bij het verlaten van de vergaderzaal tegen een christenbroeder: "Tilanus, God regeert tóch !" 38 Maar het kabinet is demissionair en doet alleen nog de lopende zaken.

\section{* Virtueel vlootakkoord}

En zo zijn dan de vlootwet en daarmee de defensie van Indië na een voorgeschiedenis van bijna twintig jaar weer terug bij af. Een treurspel dat in 1905 begon, toen de eclatante overwinning van Japan op Rusland in het Verre Oosten de achtereenvolgende kabinetten het noodsignaal gaf, afdoende beveiligingsmaatregelen in de Indische archipel te treffen om de expanslepolitiek van Nippon een halt toe te roepen.

Wat ging er nu eigenlijk mis met de vlootkwestie ? Is het echec - afgezien van de opstelling van de linkerzijde met haar uiteenlopende verzetsgronden tegen the noble ... self-defense - de schuld van het kabinet, van Nolens en/of van Van Schaik c.s.?

Eerst maar eens het kabinet. Waar het kabinet stellig in tekortschoot, was in een ordelijke regie van het vlootproces. Het had immers voor het ontwerp van de vlootwet, dat volgens het regeerakkoord werd "aangehouden" in afwachting van het daarover uit te brengen advies van de staatscommissie, in wezen niet méér dan virtuele steun van de drie regeringsfracties. Toen in de ministerraad van mei-juni 1923 aan de orde kwam of het kabinet het - positieve - advles van de commissie moest overnemen, liet men na de zwakke schakel in het geheel, namelijk de eerder vertoonde weifelachtige houding van de RK kamerclub, vooraf - via de relatielijn Ruys-Nolens - op zijn hechtheid te testen. Dan was ook gebleken dat er bil de monseigneur weinig geestdrift voor de defensieplannen bestond en men van diens verdediging van het ontwerp in de fractie geen hoge verwachtingen mocht koesteren.

Weliswaar had Nolens het regeerakkoord met inbegrip van de vlootparagraaf namens zijn fractie op 4 september 1922 meeondertekend, maar in de eigen kamerclub sprak hij daarbij als zijn overtuiging uit dat de adviesaanvraag aan de staatscommissie niets anders betekende dan een kapstok om definitief van die lastige vlootkwestie af te zijn.

Nogal roekeloos van Nolens, die hier de opstandige geest uit de fles liet 
ontsnappen, terwijl het hem uit de formatieonderhandelingen dubbel en dik bekend was hoe stevig de AR en de CHU het kabinet èn de katholieke coalitiegenoot op de vlootaanbouw wensten vast te pinnen.

Toen dat geschipper van de fractieleider eenmaal aan het licht was gekomen, kreeg hij niet alleen een hoop kritiek van de groep-Van Schaik over zich heen, maar hekelden ook de partijtop en Ruys diens "slappe houding ${ }^{* \prime \prime} .39$

Wat valt after all de op een verkeerd spoor gezette "rebellen" te verwijten? Zeker, men kan Van Schaik tegenwerpen dat diens betoog als zou de vlootwet het zeedefensiebeleld voor zes jaar aan de invloed en de controle van de Staten-Generaal onttrekken, geen hout snijdt. Staatsrechtelijk en - gegeven de gefaseerde aanpak van het vlootplan - oók feitelljk heeft het parlement immers nog steeds vrij spel om "ieder oogenblik, althans ten minste jaarlijks" op dat plan terug te komen. Desondanks is er onvoldoende reden voor, hem en de zlinen hard te vallen over hun stemgedrag. In laatste instantie behoort immers elk kamerlid autonoom te bepalen wat het in de gegeven omstandigheden verantwoord acht! ${ }^{40}$ En natuurlijk is het flauwekul om de tien "vrienden" - zoals een rijmelende antirevolutionaire oud-minister van koloniën doet - te betichten van verraad:

Ruys' Kabinet stond 5 jaar pal,
Tien "vrienden" brachten het ten val.

Het tiental laat zijn leiders staan!

"Wat gaat ons Ruys, wat Nolens aan ?"

Zij kiezen liever Troelstra's zij,

Dan heeten zij immers fier en "vrij".

Ruys' Kabinet stond 5 jaar pal,

Tien dwazen brachten het ten val. ${ }^{41}$

\subsection{Het laatste redmiddel}

De viering van Wilhelmina"s zilveren regeringsjubileum is nauwelijks anderhalve maand verstreken, of de vorstin staat voor een kabinetscrisis die complexer is dan ooit in de voorbije 25 jaar.

De reeks consultaties begint op maandag 29 oktober. Koolen, de voorzitter van de Tweede Kamer, slaat meteen de spijker op de kop. Om een kabinet samen te stellen uit de groepen die het kabinet-Ruys ten val brachten, zou niet reëel zijn, betoogt de adviseur, "... [omdat] hen niets 
gemeenschappelijks [bindt] dan dat zil] niet wenschten dat het vlootplan bij de wet wordt vastgelegd... Er zou dus aan de leiders der drie rechtsche partijen gevraagd moeten worden of er nog lust tot verdere samenwerking bestaat ... Wordt op de vraag toestemmend geantwoord, dan bestaat de basis voor een nieuw rechtsch parlementair Kabinet. Mocht op deze vraag ontkennend worden geantwoord, dan zou zich de noodzakelijkheid voordoen van een zakenkabinet, dat wegens de rechtsche meerderheid rechtsch zou moeten zijn georiënteerd ..." 42

Ook Nolens. Troelstra en Marchant wijzen in hun adviezen aan de koningin een opdracht aan de groep van de "vijftig tegenstemmers" als een tot mislukking gedoemd experiment krachtig van de hand. Laat eerst de rechterzijde maar eens proberen een nieuw parlementair kabinet te vormen, is hun mening. Volgens Rutgers en Schokking pleegde de katholieke fractie coalitiebreuk en in zo'n situatie behoort ${ }^{43}$ het kabinet te doen wat het deed, namelijk aftreden om plaats te maken voor de "brekers". Qui casse, paye derhalve, en zou dan "hoofdschuldige" Van Schaik nlet logischerwils heelmeester moeten zijn ? Nee, diè achten de beide heren niet ministeriabel, maar voor hen is wèl Troelstra of Marchant een serieuze optie.

In de lijn van Koolens advies legt de koningin de drie (grote) rechtse fracties begin november de vraag voor of zij bereid zijn samen te werken in een nieuw rechts kabinet. De reactie van de RKSP is positief, van de CHU niet afwijzend, van de AR negatief.

De formatie zit in de knoop: rechts is te tweedrachtig, links te onmachtig om een kabinet te vormen. Zou wellicht een bekwame man als de Tweede-Kamerwoorzitter de knoop kunnen ontwarren?

En inderdaad, op 15 november krijgt Koolen van Hare Majesteit de - ruim gestelde - opdracht "een nieuw kabinet" te formeren.

\section{* De formatiepoging van Koolen}

Doelgericht start de pas benoemde formateur ziln werkzaamheden met een bezoek aan Rutgers. De antirevolutionaire fractieleider maakt er geen gehelm van dat herstel van de samenwerking volstrekt uitgesloten is zokang de katholieken hun houding van 26 oktober niet grondig veranderen. In het gesprek opent zich voor een katholieke formateur die aanstuurt op een rechts kabinet geen hoopgevend perspectief. Het enige uitzicht dat Koolen rest, is dat Nolens maar eens met Rutgers gaat praten.

Bij de door Koolen gearrangeerde ontmoeting van beide fractieleiders stelt Rutgers de bereldheid van ziln partil om met de katholieken de bespre- 
kingen over verdere samenwerking te openen, afhankelijk van drie voorwaarden: aanvaarding van de - hooguit op ondergeschikte punten te wilzigen - vlootwet; aanvaarding van alle door de regering voorgestelde bezuinigingsmaatregelen, ofwel van alternatieven die gelijk financieel resultaat hebben en waarmee de bondgenoten kunnen instemmen; erkenning van de schending van het vlootalkkoord, onder verlening van toestemming tot openbaarmaking van die schuldbekentenis.

Hier vertoont zich de engel der wrake met zijn ongematigde boodschap ! Nolens en Koolen hoeven er geen lange nabespreking aan te wijden: "Niet te aanvaarden, kan nlet." 44

Inmiddels mengt zich ook de nestor van de staatslieden in het politieke strijdgewoel. Lohman, sinds twee jaar "meelevend" politicus in ruste, voelt zich geroepen in zijn dagblad De Nederlander uiting te geven aan zijn verontwaardiging over de steile houding van de mannenbroeders. Eisen zll niet: "of den heer Colijn volgen in alles - òf eene gezonde oplossing der crisis zooveel mogelijk bemoeilijken ?" ${ }^{45}$ Zo is het maar net, vindt ook de RK fractie, die in haar vergadering van 23 november de eisen van de AR pertinent afwijst.

Daags daarna meldt Koolen de koningin dat zijn poging tot herstel van de coalitiebreuk is mislukt. Ook is het hem niet mogelijk een kabinet op bredere basis te formeren, omdat de grootste fractie - de katholieke - er naar zijn informatie niets voor voelt samen met linkse partijen te regeren. $\mathrm{Nu}$ per saldo een extraparlementair kabinet in beeld komt, zou voor de formatie daarvan, aldus Koolen, "een invloedrijke man, die in de politiek niet naar voren is getreden" ${ }^{46}$, de aangewezen persoon zijn.

\section{* IJdele hoop}

Hoe serieus Wilhelmina incalculeerde dat de formatiepoging van Koolen op niets zou uitlopen, blijkt uit het scenario dat haar dagorde van 24 november bepaalt. Koolen is nauwelijks vertrokken of een "in de politiek niet naar voren getreden man" maakt zijn opwachting op Het Loo. De politieke buitenstaander aan wie de koningin een belangrijke staatszaak wenst toe te vertrouwen is een oude bekende van haar: de diplomaat jhr. mr. F. Beelaerts van Blokland, gehuwd met een gewezen hofdame, die een goede vriendin van de vorstin is.

Op hem vestigt zij de hoop dat een extraparlementair kabinet spoedig een eind aan de crisis zal maken. Beelaerts ( $\mathrm{CHU}$ ) heeft er een zwaar hoofd in, maar gaat als een gehoorzame dienaar aan de slag. De kracht van een extraparlementair kabinet waar geen van de partijen vaste steun aan wil geven, moet uitgaan van "mannen van algemeen erkende bekwaamheid 
en van groot persoonlijk gezag" ${ }^{47}$ "stelt Beelaerts zich voor. De kunst is echter zwaargewichten te vinden die in zo'n kabinet willen zitten. Niemand dus, zodat de formateur de koningin op 5 december een onaangename surprise moet bezorgen.

De zaak zit nu behoorlijk in het slop. Ruys is uitgeregeerd, links is niet aan regeren toe, een gemengd kabinet stuit af op Nolens' afwijzing van samenwerking met de SDAP ${ }^{43}$, de extraparlementaire variant is net mislukt en de ongenaakbare houding van Colijn c.s. staat een rechtse formatie in de weg.

Na consultatle van Nolens besluit de koningin op 8 december Colijn voor het eerst in het beraad over de crisis te betrekken. Haar plan is, de formatie van een nieuw rechts kabinet in handen te leggen van Colijn én een katholiek.

Het idee van Hare Majesteit werkt als een waar wondermiddel: in zes dagen spelen Colijn en Nolens het klaar dat de Tweede-Kamerfracties van de AR en de RKSP akkoord gaan met de formatie van een nieuw rechts kabinet door het duo Colijn-Ruys. Nu nog vlug de $\mathrm{CHU}$ inlichten en zich van haar medewerking verzekeren. Colijn zal dat zaakje wel even opknappen, maar gepikeerd over de gang van zaken laten de christelijk-historischen hem weten dat zij een formatie door een tweetal dat medeverantwoordelijk is voor de crisis, niet zien zitten.

Op 22 december verneemt de koningin van Colijn dat thans de $\mathrm{CHU}$ dwarsligt.

\section{* De rechterzijde voor het blok}

Nòg laat de koningin de hoop op een nieuw rechts kabinet niet varen. Zonder advies in te winnen over haar volgende zet, wijst zij op 24 december "de rechterzijde" tot formateur aan. Wilden de direct betrokkenen de "dubbelformatiepoging" van zojuist vooral binnenskamers houden, van de nieuwe collectieve opdracht verschijnt daarentegen nog dezelffle dag een offlciële bekendmaking.

De Kroon heeft de kabinetsformatie uit handen gegeven en doet daarmee ten gunste van de rechterzijde afstand van de allervoornaamste functie die de constitutionele vorst nog kan verrichten, hekelt de linkse pers. Hoezo de koningin gezwicht voor een coup van de rechtse "junta", die juist doodongelukkig is met de pressie die het staatshoofd op háár uitoefent ?! Uit staatsrechtelijk oogpunt kan met overigens wel ernstige bedenking hebben tegen het feit dat de opdracht onpersoonlijk is. Degene die op een gegeven ogenblik een formatieopdracht aanvaardt of van de hand 
wijst, zal zich voor de door hem of haar gevolgde gedragslijn toch moeten (kunnen) verantwoorden, waarbij zich steeds, aldus Van Raalte ${ }^{49}, "$ "... op de achtergrond de schaduw van het Parlement [blijft] aftekenen ..." Wie controleert in casu dan eigenlijk wie?

Het is kerstavond als de drie rechtse fractieleiders samen enkele uren de opdracht verkennen. Dringender plicht belet het drietal echter de knoop nog vóór middernacht door te hakken. Men geeft elkaar enige dagen respijt om een en ander goed op zich te laten inwerken. De CHU is daar gauw uit. Met een verse herinnering aan het onderonsje van AR en $R K$ in de vorige fase, laat zij de koningin op 27 december weten niet bereld te zijn aan de collectieve opdracht mee te werken. En zo sleept de kabinetscrisis zich maar voort.

Wat kan de koningin, nu ook de vierde formatiepoging is mislukt, anders doen dan de ontslagaanvraag van het kabinet-Ruys weigeren ?

Wilhelmina's vrees dat het dit kabinet, voortgekomen uit de rechterzijde waarvan de eenheid is gebroken, bil zijn heroptreden zou ontbreken aan voldoende kracht en gezag, doet haar evenwel besluiten advies te vragen aan een van haar meest bekwame en gewaardeerde steunpilaren, de $\mathbf{M}$ nister van Staat Cort van der Linden. De oud-premier deelt haar gevoelen dat het aanblijven van het kabinet grote risico's met zich brengt en geeft haar in overweging de poging tot vorming van een extraparlementair kabinet te herhalen.

Ditmaal mag de demissionaire minister van buitenlandse zaken Van Karnebeek in het geheim een poging wagen. Nolens en Collin blijken echter meer dan genoeg van uitzichtloze probeersels te hebben, waama Van Karnebeek niets anders rest dan de koningin op 5 januari 1924 te adviseren het laatste - en zeker wel riskante - redmiddel te beproeven ...

\subsection{Gelukkig dat Ruys er nog is}

Aldus strandt met Van Karnebeeks stille aftocht de vijfde formatiepoging op rij. De kabinetscrisis houdt maar aan, tien weken inmiddels, terwill het land zit te springen om een krachtige regering.

Intussen passen Ruys en zijn demissionaire ploeg op de winkel, waar trouwens de bedrijvigheid tijdens de "verbouwing" op een laag pitje staat. Het kost de op vertrek staande premier weinig moeite tussen de bedrijven door tijd te vinden om de opeenvolgende formateurs Koolen en Beelaerts met raad en daad bij te staan of eens een extra ommetje met Nolens te maken. Na hun favoriete Scheveningse windvang op 11 november, laat 
Ruys echter een poosje verstek gaan en wimpelt hij zijn ongeduld wachtende - "Waar blijf je?" - wandelmaat af met: "Ik wil niet [den] indru maken te visschen of te willen blijven." ${ }^{51}$

Niettemin maakt Ruys zich grote zorgen over de crisis. Als Nolens he een maand later - telefonisch - benadert met het verzoek samen $\mathrm{m}$ Colijn als formateur op te treden, gaat hil met deze meteen in het Torent aan de slag om een concept-regeerprogram op te stellen. Nauwelijks even later de panklare oplossing van dit duo door de weigering van $c$ CHU weer van de baan, of Ruys en Nolens putten zich gezamenlijk uit het bedenken van andere mogelijkheden. Waarom zou het kabinet te langen leste niet blijven zitten en bij een nieuw conflict de kamer ontbir den ?. oppert Nolens. Maar Ruys is niet belust op een avontuur dat ve keerd kan uitpakken voor de politiek en ... de partij. ${ }^{52}$

De formatiepuzzel laat de demissionaire premier niet los als hij na afloc van het gesprek de trein naar het zuiden neemt om hier bij ziln vader - zi moeder is vorig Jaar overleden - op Wolfrath de kerstdagen door te bre gen. Voordat hil bil aankomst in Roermond overstapt op de boemeltre richting Sittard, laat hi] Nolens nog even zijn nieuwste inval weten: ee links georiënteerd zakenkabinet, te vormen door de rustige en onpartijdig Commissaris der Koningin in Drente, zou men dáámee niet uit de pro blemen ziljn ? ${ }^{53}$

Eerste kerstdag leest Ruys in de krant dat de rechterzijde daags tevore tot formateur is benoemd en vertrekt spoorslags naar het crisiscentrun Het verloop van de vierde fase van de formatie is hem daar echter te vlu af. Wel neemt hil de tijdelijke "radiostilte" te baat om zijn vriend Van $\mathrm{Nis}$ pen op 28 december te schrijven over de onmogelijke toestand hier, di "... zal gevolgd worden door ... ?" ${ }^{54}$ Een bezoekje van ... Van Karnebeel die "zijn chef" op 4 januari verwittigt van zijn geheime formatieopdrach en de demissionaire premier een dag later komt vertellen dat hij zijn po gingen opgeeft. ${ }^{55}$

Ruys weet wat hem te wachten staat als de koningin hem op 7 janua wenst te spreken. $Z$ ij deelt hem mee dat na een crisis van ruim tien weke met vilf vergeefse formatiepogingen, het landsbelang haar niet toestaat $d$ ontslagaanvraag van de premier en zljn collega's in te willigen.

\section{* Als feit aamvaard}

Na een demissionaire status van 74 dagen is het kabinet weer volwaardi terug. In de regeringsverklaring die Ruys op 15 januari 1924 in de Tweed Kamer aflegt, komt naar voren: "Nu ... een langer slepend blijven van d crisis niet in 's Lands belang kon worden geacht, meenden wij ons niet $t$ 
kunnen onttrekken aan den plicht, de verantwoordelijkheld voor het bewind te blijven dragen... De beslissing der Kamer van 26 October wordt door het Kabinet in de gegeven omstandigheden als feit aanvaard ... Het treffen van een voorziening inzake de maritieme verdediging zal daardoor eerst kunnen volgen op maatregelen tot herstel van het financieel evenwicht. Deze, bereids beraamde, maatregelen ter genezing van het ziekteproces, dat 's Lands financiën doormaken, staan thans op den voorgrond. Middelerwijl zal de Regeering de verzorging van de maritieme verdediging opnieuw ter hand nemen ... De Regeering doet nu een beroep op de medewerking van de Staten-Generaal, ... wanneer zil haar thans uitnodigt tot gemeenschappelijken arbeid, teneinde aan de hangende vraagstukken de oplossing te geven die het land zo dringend behoeft." 56

Ruys is weer terug ! Hij zocht de comeback niet, maar nu de plicht hem roept, weet hij waar zijn plaats is.

Gemoedelijk en bescheiden, gehecht aan goede menselijke verhoudingen en steeds met een open oor voor de ander op zoek naar consensus, is hi] een man die als ras-Limburger wel eens een duwtje in de rug kan gebruken, maar dan vervolgens ook rustig doortast om in dagen van dreigende, uitgebroken of net-bedwongen crisis de staatkundige toestand die zo op scherp staat, tot bedaren te brengen. "Gelukkig dat Ruys er nog is." ${ }^{57}$ Dat is voor menigeen alvast één troost als het in politiek Den Haag weer eens goed rommelt.

\subsection{Het waagstuk loopt goed af}

Zonder kleerscheuren overleeft het kabinet het kamerdebat dat op de regeringsverklaring volgt. Weliswaar voelt de linkerzijde Ruys stevig aan de tand over het gegoochel tijdens de crisisperiode, maar als de premier haar verzekert dat de ministers daar in hun hoedanigheid volledig buiten stonden, is het verhoor niet langer zinvol en moet ók de oppositie de wederopstanding van het kabinet wel als felt aanvaarden.

$\mathrm{Na}$ al het oponthoud van de laatste maanden kan nu eindelijk de behandeling van de begroting voor 1924 starten. De financiële plannen die Colijn in afwijking van de miljoenennota presenteert, beperken de bezuinging op de rijksdienst van 50 tot 30 miljoen, waartegenover nieuwe indirecte belastingen en een hogere opbrengst van de inkomstenbelasting aanvullende dekting moeten bieden. Zoals gewoonlijk is het leeuwendeel van de "efficiencyslag" voor rekening van onderwijs en defensie, en dienen al even traditioneel de ambtenarensalarissen als slultpost op de be- 


\section{groting.}

Net als een goed jaar geleden krigt onderwijs een zware aanslag te verwerken. Ditmaal moeten een hogere leerlingenschaal en lagere salarissen samen $f 12,5$ miljoen opbrengen. Zó blift geen spaan heel van het onderwijs, opponeert de linkerziljde. De grote boosdoenster is, volgens links, de pacificatie van 1917, die "de citroen van de financiële gelijkstelling steeds verder uitknijpt". ${ }^{58}$

Als minister De Visser er niet aan wil, op verzoek van links een onderzoek nat een meer bevredigende uitvoering van dat stelsel te laten instellen, komt men van die zijde met een amendement dat Gedeputeerde Staten de bevoegdheid wil geven om oprichting van een bijzondere school op kosten van de overheid te verhinderen indlen binnen een afstand van 4 $\mathrm{km}$ een school van dezelfde of verwante richting aanwezig is.

Op hetzelfde ogenblik is de coalitie weer hecht als vanouds: allemaal vóór de bezuinigingsplannen en tegen het amendement. Maar helaas, deze parlementaire krachtmeting heeft tot gevolg dat van de zevenjarige onderwijsvrede niets anders overbilift dan een wankel bestand tussen links en rechts.

Tussen links en groot rechts wel te verstaan, want klein rechts pacteert met niemand en zeker nooit met die verfoeilijke ultramontanen, wier scholen in deze protestantse natie geen centje recht op bijdragen uit de staatskas hebben. Ja, als het die klein-rechtse papenhater Gerrit Kersten beter uitkomt, neemt hij het niet zo nauw met de grondwet. Dit laatste geldt trouwens ook voor bovengenoemd amendement, dat, zoals - voorstemmer - Oud erkent, "... inderdaad het beginsel dat de ouders over de richting van de bijzondere school hebben te oordelen, [aantast]." 59 Leve de onderwilspacificatie! Zegt dan tòch een minister van binnenlandse zaken, tevens geestverwant van Oud, ruim zeventig jaar later langs zijn neus weg: "Och, dat grondwetsartikel [23] hebben we zo langzamerhand niet meer nodig..." "?

Ook oorlog en marine moeten het samen $f$ 12,5 miljoen kalmer aan doen. De materiële begroting van beide miltäre ministeries bledt daar echter niet de minste ruimte toe omdat geweren en kanonnen uit de vontge eeuw, Engelse-legerdump van '14-"18 en totaal "opgevaren" schepen nu ècht aan vervanging toe ziln. De bedroevende gesteldheid van de uitrusting van leger en vloot laat de ministers Van Dijk en Westerveld geen andere keus dan het budget voor aanschaf van nleuw materieel volledig te ontzien en in plaats daarvan te pogen de posten personeel en organisatie van het defensieapparaat extra omlaag te schroeven.

Minder perspectivistisch zijn de maatregelen waarmee Colijn zelf voor de 
dag komt. In zijn streven naar herstel van het begrotingsevenwicht wll hil in 1924 minstens $f 50$ miljoen méér belastinggeld beuren. Nu de economie weer aantrekt, is een hogere opbrengst van de inkomstenbelasting verzekerd en kan een verhoging van het desbetreffende tarief als schadelijk voor kapitaalvorming en de algemene volkswelvaart achterwege blijven. Maar omdat de baas van financiën dringend om geld verlegen zit, heeft hij natuurlijk wel iets anders achter de hand: met heffingen op zogeheten artikelen van algemeen gebruik boort hij zelfs een onultputtelijke belastingbron aan. Door de hogere accijns op thee en bler en het verplichte "rijwlelplaatje ${ }^{\text {n }}$ op de fiets, worden voor ledereen op zijn minst twee primaire levensbehoeften een stuk duurder.

De algemene volkswelvaart is zo tòch de dupe, maar de schatkist vaart er wel bij. Als de minister van financiën straks de rekening over $1924 \mathrm{op}$ maakt, blijkt dit met zo'n groot begrotingstekort ingezette jaar te sluiten met een batig saldo van ettelijke miljoenen. En dat, terwijl de bezuinigingen op defensie en de salarismaatregelen van de regering nog steeds niet voor het volle pond effect sorteren.

\section{* Tegen alle "verkregen rechten" in}

Van alle bezuinigingsmaatregelen die het kabinet wil treffen, is de korting van $f 60$ miljoen op de ambtenarensalarissen de meest ingrijpende èn ... de felst betwiste, zoals aanstonds blijkt.

Wat is het geval ? In een bij KB van 23 Januari 1920, Staatsblad nr. 37 , vastgestelde nieuwe bezoldigingsregeling ging de regering ertoe over de ambtenarensalarissen vanwege de destijds heersende duurte aanzienlijk te verhogen. De regering behield zich in de nieuwe regeling evenwel voor, de salarissen bij vermindering van de duurte dienovereenkomstig te verlagen. onder handhaving van de eenmaal toegekende wedden. Al gauw zit het kabinet-Ruys met die garantiebepaling behoorlijk in zijn maag. Het heeft een "staatsrechtelijk monstrum" gebaard, dat een sta-in-de-weg is voor een algehele salariskorting. Twee jaar later trekt de regering bij KB van 19 juni 1922, Staatsblad nr. 400, dat obstakel voor toekomstige bezuinigingen dan ook weer in, maar laat daarbij de garantie voor de op 1 jull 1922 in dienst zijnde ambtenaren - de enige lichting die anders helbel zou kunnen maken - voortbestaan.

Uit financiële noodzaak wil het kabinet in 1924 van die garantiebepaling in het bezoldigingsbesluit van 1922 af. Reeds uit het voorlopige verslag van de voorbereidende behandeling van het eerste hoofdstuk van de begroting voor 1924 blijkt dat "verscheidene" leden van de Tweede Kamer ernstige bezwaren hebben tegen de voorgenomen maatregel. In de memorle van 
antwoord wijst de regering op het specifieke karakter van de ambtenaarsverhouding, die immers niet berust op een overeenkomst naar burgerlijk recht, maar - haars inziens - ontstaat door een eenzijdige overheidsdaad de aanstelling -, waarin ook de bevoegdheid ligt opgesloten om de rechtspositie van de ambtenaar eigenmachtig te wijzigen.

Tijdens de mondelinge kamerberaadslaging halen Marchant en Troelstra fel uit naar de "apert onjuiste" juridische beschouwingen van het kabinet. Met volle instemming refereert de sociaal-democraat aan het vernietigende oordeel van staatsraad mr. J. Oppenheim, ooit Ruys' leermeester in het staatsrecht, die het plan van de regering uitmaakt voor "een allerschandelijkst bedrijf en moreel noolt te verdedigen". ${ }^{60}$ Ruys geeft toe dat de garantie van 1922 een bestuursrechtelijke misser is, maar het boetekleed mag de overheid niet beletten de fout te herstellen als overmacht haar dwingt de eenmaal toegekende salarissen te verlagen. En ondanks een golf van kritiek uit de hoek van de vrijzinnig- en sociaal-democraten en de ambtenarenorganisaties gaat bij KB van 7 april 1924, Staatsblad nr. 172, dan ook een streep door de garantiebepaling van het bezoldigingsbesluit van 1922 .

Helemaal zeker van zijn zaak is het kabinet kennelijk niet. De wetenschap namelijk mag dan wel verdeeld denken over de grondslag van de ambtenaarsverhouding, maar schrijvers als Buys, Krabbe en Lohman zijn bepaald niet de eersten de besten die de relatie overheid-ambtenaar zien als een "vrij verdrag", dat niet zonder wilsovereenstemming ontstaat en tussentijds wijziging kan ondergaan. ${ }^{61} \mathrm{Om}$ in de gegeven omstandigheden niet het risico te lopen dat de ambtenaren hun gelijk bij de rechter zouden halen, komt het kabinet daarop met het voorstel, de bevoegdheid van de overheid om - ook eenmaal toegekende - rechten van ambtenaren eenzidig te wijzigen, te verankeren in een wet in formele zin. Dat het intrekkingsbesluit op die manier niet meer vatbaar is voor rechterlijke toetsing, brandmerkt vrijzinnig en socialistisch links als een schandalige poging om de kamer medeplichtig te maken aan het verraad tegenover de ambtenaren.

Het wetsontwerp is ook Nolens - in zijn vije tijd sinds 1909 buitengewoon hoogleraar in het arbeidsrecht aan de Universiteit van Amsterdam - te gortig. Minister Heemskerk kan nu wel betogen slechts een bestaand gewoonterecht te willen vastleggen, maar met dat al heeft het wetje, aldus de katholieke-fractieleider, het "buitengewoon zwaar wegend bezwaar" dat het justitiabelen de pas naar de rechter afsnijdt. 62 Met een grote meerderheid verwerpt de kamer vervolgens het wetsontwerp, dat slechts de steun van de AR en de Vrliheidsbond krligt. 
De weg naar de rechter blijft dus open. En dat komt heel wat ambtenaren goed van pas, nu koud drie weken na de intrekking van het garantieartikel óók de op $\mathbb{1}$ juli 1922 geldende salarissen met $10 \%$ omlaaggaan. Jarenlang voeren zij voor de rechter een harde strijd om erkenning van "verkregen rechten", maar verliezen uiteindelijk het pleit tegen de staat als de Hoge Raad in zijn arrest van 25 maart 1927, N.]. 1927, blz. 412, uitmaakt: " ... dat art. 40 [de garantiebepaling] van het Bezoldigingsbesluit 1920 is vastgesteld bij algemeenen maatregel van bestuur en eveneens bij algemeenen maatregel, dus door een daad van denzelfden wetgever, is geschrapt; dat, waar een latere uiting van een wetgever voorrang heeft boven een voorafgaande, het gevolg van die intrekking is geweest, dat art. 40 met den daarin vervatten waarborg verdween en aan dat artikel op zichzelf daarna geen rechten meer konden worden ontleend."

Zijn nu alle illusies van ambtenaren in rook vervlogen, evenzeer moet Marchant, die de ambtenarenorganisaties tot in hoogste instantie als advocaat terzijde stond, tot zijn ergernis ervaren hoe het bevoegde gezag met "verkregen rechten" om mag gaan!

Voor de vrijzinnig-democraat is er tenminste nog iets dat het leed verzacht:

Ambtenaar, een kein salaris.

Burger en tòch democraat.

Dat le voorts ontwapenaar is,

Maakt, dat le dicht bij ons staat. ${ }^{63}$

De algehele salarisverlaging per 1 mei 1924 effent natuurlijk een lastige hobbel op de weg naar financleel herstel. Met "de centen uit het bloed en zweet der ambtenaren" ${ }^{64}$ en een aanvullend belastingprogram - verhoging van de invoerrechten en de tabaksaccijns - zlet Colijn kans om een sluitende begroting voor 1925 te presenteren. De schatkist gaat een jaar met een ongekend hoog overschot van $f 44$ miljoen tegemoet.

\section{* De finale van het politieke bedriff}

Na een wereldwijde economische en monetaire crisis die zich in 1921 openbaarde en vier jaar aanhield, breekt in 1925 overal een perlode van opgaande conjuctuur aan. Ook in ons land gaat het de eerstkomende jaren crescendo. Handel en nijverheid bloeien op, de werkgelegenheid neemt sterk toe en de gesaneerde financiën maken van de eigen munt weer een harde valuta. 
Op 28 april 1925 verschiljnt Colijn onaangekondigd in de vergadering van de Tweede Kamer om er heet van de naald een verklaring "van groot gewicht voor het internationale betalingsverkeer" af te leggen. De minister onthult dat Nederland samen met Engeland en zijn dominions op het punt staat het embargo op gouduitvoer op te heffen en na elf jaar terug te keren tot de Gouden Standaard.

Is dát even een grandioos statussymbool. Wat je ervoor koopt? De Chancellor of the Exchequer, Winston Churchill, en diens Nederlandse ambtsgenoot Hendrikus Colijn zijn er in elk geval reuze verguld mee!

Nog vóór de aprilmaand voorbij is, krijgt de Tweede Kamer opnieuw een internationale aangelegenheld voorgeschoteld. Er speelt namelijk al tijden een kwestie met België, die zojuist in eerste aanleg bij traktaat is afgedaan, maar wel nog ter goedkeuring de Staten-Generaal moet passeren. Tijdens de Parijse vredesconferentie van 1919 stelde België - tegen zijn wil in de oorlog betrokken en zwaar door dit geweld getroffen - alles in het werk om bij de geallieerden gehoor te vinden voor een herziening van de Londense verdragen van 1839 , die het land verplichtten tot strikte neutraliteit ... en aanvaarding van de toewijzing van Zeeuws-Vlaanderen, Maastricht en het overmase deel van Limburg aan Nederland. België. dat zich door die grensregeling sterk belemmerd voelde in de verdediging en economische ontwikkeling van het land, claimde in Parijs natuurlijke grenzen die het hele gebied van de Schelde en de Maas tot boven Venlo - bij elkaar heel Zeeuws-Vlaanderen en driekwart van Limburg - zouden omvatten.

De geallieerden gaven daarop de Nederlandse regering de gelegentheid om haar standpunt over een eventuele herziening van de Londense verdragen uiteen te zetten. Door een resolute afwijzing van de Belgische aanspraken op Nederlands staatsgebied, wist Van Karnebeek de plannen van de opdringerige zuiderbuur van tafel te krijgen, waarna de grote mogendheden beide kemphanen opdroegen een schikking te treffen over een verdragsherzlening zonder "overgang van territoriale soevereiniteit".

Bỉnnen een Jaar zijn Noord en Zuid het eens over gemeenschappelijk beheer van de Scheide en aanleg van kanalen die Antwerpen verbinden met Moerdijk en de Rijn. Niets lijkt een spoedige ondertekening van het verdrag meer in de weg te staan, tot België opeens de soevereiniteit over een deel van - de Wielingen opeist. Prompt raken de onderhandelingen in een patstelling. Het duurt vijf jaar eer de twee zo hecht verbonden landen de besprekingen hervatten, de Wielingenkwestie onopgelost laten en het herzleningsverdrag op 3 april 1925 van hun handtekening voorzien.

Op 29 april bereikt de Tweede Kamer het voorstel tot goedkeuring van het 
verdrag. Handelskringen in Rotterdam reageren panisch, die in Amsterdam lauw, maar waar straks voor een keer écht de volksovertuiging dooklinkt, is in een eerbiedwaardig vijftigkoppig gezelschap op het Binnenhof in Den Haag.

In de finale van het politieke bedrijf mogen ook de schone kunsten nog even de zinnen boeien. De Visser, de portefeuillehouder van Kunsten, die het in 1923 bestond zich te laten vertegenwoordigen bij Louis Couperus' crematie - een ontoelaatbare uitvaart naar de opvatting "Van oude mensen, ..." 65 -, krijgt in 1925 een ultieme kans om die "schandvlek" op zi|n blazoen weg te werken. De Olympische Spelen van 1928 gaan naar Amsterdam ! En dat prestigieuze evenement wil het kabinet best wel sponsoren. Dus gordt de minister van OK\&W zich ten strijdle om het subsidievoorstel in de kamer te verdedigen. In een hoogoplopende theologische redetwist met de volgelingen van Calvijn haalt de bewindsman - toch lemand die op het gebied van de godgeleerdheid zijn mannetje staat ! eind mei 1925 echter bakzijl met zijn "heidensche en de kleschheid der vrouw bedreigende promotieplan". ${ }^{60}$

Ongetwijfeld doet het de onbekrompen staatsman-theoloog deugd dat Wilhelmina zich niets van dat kamerdebat aantrekt. Zíj ziet er drie jaar later tijdens de Spelen - vrouwen mogen dan voor het eerst ook aan atletiek meedoen - geen been in om zegevierende seksegenotes met goud te behangen.

\subsection{Balans van drie jaar Ruys II}

Begin juli 1925. De Tweede-Kamerverklezing staat voor de deur. Volgens de nieuwe spelregel van 1922 bieden de ministers de koningin ditmaal zonder treuzelen hun ontslag aan en zetten een punt achter een regeerperiode, gekenmerkt door belangrijke wetgeving, coalitiezeer, vlootmiserie, politieke crises, drastische bezuinigingen en financieel herstel.

Drie jaar Ruys II geeft bepaald geen opbeurend totaalbeeld te zien. Ja, Heemskerk en Aalberse leveren ook nu weer prima werk, dat hun reputatie van eerste-klas-wetgever bevestigt. En in de persoon van Colljn zijn de financiën in handen van een onmiskenbare Macher. Maar weeffouten tijdens de kabinetsformatie, een troebel vlootakkoord, alsook het geljjktijdig opvatten van een ingrijpende bezuinigingsoperatie en een duur en omstreden vlootplan maken van deze jaren een periode waarin de coalitie van de ene in de andere crisis verzeilt.

Formateur Ruys heeft in 1922 alle reden om zich te verbazen over de 
houding van De Geer, die opeens niets meer voelt voor het ontwe vlootwet, dat sinds 1921 met zijn mede-ondertekening bij de kamer De noodgreep die Ruys vervolgens doet om De Geer voor het kabinet behouden, is slechts uitstel van executie: wát de in te stellen stac commissie straks ook over de vloot adviseert, nooit kunnen daar én Geer én Westerveld én alle coalitiefracties genoegen mee nemen.

Het lijkt toch allemaal redelijk hard èn bevattelijk als de coalitie op $4 \mathrm{st}$ tember 1922 tot een akkoord komt over een in alle geval in zes jaar op leveren en in twaalf jaar af te betalen vloot van gespecificeerde same stelling ?! Maar waarom dan de behandeling van het vlootontwerp aa houden in afwachting van het advies van een commissie die geen kant kan ? De protestantse fracties hebben aan zo'n geijkt zlipaadje om e kloof in coalitiestandpunten te ontwijken, geen behoefte. Behalve als advies nog eens zou benadrukken: "dat de Regeering niet mag aarzelen doen wat in haar vermogen is om de aanneming en de dadelijke uitvc ring van de Vlootwet te verzekeren." Daarentegen geldt voor Nolens leden van ziln fractie bij wle ook "weinig geestdrift bestaat voor de vlo plannen en andere defensieplannen": zolang er uitstel is, is er hoop afstel.

Honderdveertig miljoen willen bezuinigen en tegelijkertijd een vlootpl van zo'n kwart millard lanceren: wàt een ambitieniveau toont het kabir hier! Daar kan geen van zijn voorgangers aan tippen. Maar het bega daarmee wel de tactische fout dat het zich voor de goede zaak van e effectieve verdediging van Indië sterk maakt op het verkeerde moment. "Eerlijk gezegd", schrijft Ruys kort na de verwerping van de vlootwet a Van Nispen, "indien 't toch moest vastloopen, is deze nederlaag ge kwade. 't Is altijd beter op een nationale zaak te vallen, al is het dooc ammer voor onze Indische gewesten, wier behoud op 't spel staat." ${ }^{67}$ Moest vastlopen ? Ja, dat moest er met die onderlinge tegenstellingen v de coalitiepartijen wel een keer van komen.

Na zeven hectische jaren met veel ups en downs is dit het moment vo Ruys om de wi|ze raad van Van Nispen op te volgen: "... [neem] eens ru als Minister-President. Men kan in ons land niet wel verdragen, dat mand teveel op den voorgrond blijft. Gil zult er Uw positie in de toekom goed mede doen." 68

Ruys is niet van plan straks weer achter de regeringstafel plaats te neme laat hij zijn collega"s in de ministerraad van 29 juni 1925 weten. En ook besluiten "ongeacht den uitslag der verkiezingen" hun ontslag in te diene en naar iets anders om te zien. 


\section{EEN LANG INTERMEZZO NA EEN KORTE PROLOOG (1925-1929)}

\subsection{Inleiding}

Vóór 's Lands stuurman of tégen 's Lands zondebok, het lijkt wel alsof in de stembusstrijd van 1925 alléén Colijn de personificatie van het gevoerde kabinetsbeleid is. Enig electoraal gewin leveren hem die zwaar-aangedikte verkiezingsleuzen niet op: zijn felste bestrijders - de socialisten en de vrijzinnig-democraten - krijgen er samen zes mandaten bij, terwilj zijn eigen aanhang een verlies van drie zetels oploopt.

In het katholieke kamp is het een hele opluchting dat het verkiezingsresultaat, na al die interne heibel over de vloot, boven verwachting is. Het dagblad De Tijd is zelfs licht-euforisch van het de bescheiden teruggang $(-2)$ van de RKSP. In een extra-editie van 3 juli 1925 brengt deze krant: "... aan de onzen de blijde boodschap: de Wit-Gele-vlaggen uit I Want de R.K. Staatspartil heeft haar positie schitterend gehandhaafd: de drie groote partijen van rechts blijven in de meerderheid, zoodat ook in het eerstvolgende parlementaire tijdperk van vier jaren een Christelijk Kabinet ons vaderland zal kunnen regeeren ..."

En waar De Tijd zo vast op rekent, lijkt te gaan gebeuren als Colijn - met de krachtige steun van Nolens - op 4 augustus 1925 zijn rechts coalitiekabinet presenteert. Maar 's lands nieuwe stuurman heeft een "wit-gele" tijdbom aan boord, die wellicht al in november bij de behandeling van de begroting van buitenlandse zaken kan ontploffen. Een vaart op hoop maar zonder CHU's zegen!

\subsection{Onder het presidiaat van Ruys}

Met uitzondering van Colijn en Van Karnebeek, die in het nleuwe kabinet op hun oude post terugkeren, wisselen alle leden van het kabinet-Ruys II hun ministersambt in tegen emplooi elders.

Aalberse, Heemskerk en De Visser nemen na lange tijd weer plaats in de kamerbanken. Zo doet voor het eerst óók Van Dijk. En Ruys ?

Die gedenkwaardige zondag van 5 juli, vlak na de Tweede-Kamerverklezing! Het is dringend tijd om eens met die machtige sfinx over de formatie 
te praten. Al spoedig bemerkt de demissionaire premier dat de oude erg te spreken is over de daadkracht van Colijn, en even later is het woord in Scheveningen eruit: "Zou jii Kamervoorzitter willen worden Weggepromoveerd dus, en dat nog wel door je eigen ontdekker, r tòch maar ferm"jawel" gezegd!

Na een onderbreking van zevenenhalf jaar is Ruys weer gewoon één de honderd als de nieuwe Tweede Kamer in september voor het bijeenkomt. Even later kiest de kamer haar nieuwe voorzitter en neern oud-premier - als opvolger van de in Nolens' migratieplan met de m terssteek bedachte Koolen - plaats op het voorzittersgestoelte, een die - als een symbool van de machtsverhoudingen in het parlemen stelsel - uittorent boven het forum waar regering en volksvertegenwod ging samenkomen om de publieke zaak te dienen.

De stoelendans om twee topfuncties is afgelopen. De katholieken beh den hun viff jaar eerder - als grootste fractle - verworven voorzittersc van de Tweede Kamer. En de protestanten hebben na twaalf jaar dol hun fell begeerde premierschap terug.

Wat zou het Kuyper en Lohman opluchten als zij het met al hun bezor heid over de niet te stillen "roomse machtshonger" ${ }^{3}$ hadden beleefd de RK club thans op rantsoen staat. Hoewel, aan "de overzijde van Binnenhof" zit óók een partijgenoot van Ruys op de ereplaats. Sinds 1 - toen de katholieke partij de haar toegemeten rol van bijwagentje in politieke krachtenveld beu was - voert ginds de generaal b.d. J.J.G. ba van Voorst tot Voorst mild en minzaam de scepter over de senatoren. de leger- en de kabinetsleider in ruste zijn twee van de drie raadslie die de koningin vast hoort bij een kabinetsformatie, van katholieken hu ... en - in hun oom-neef-relatie - familie van elkaar!

\section{* De nacht van Kersten}

De kamer moet wel even slikken als het nieuwe presidium haar na Pri jesdag 1925 het straffe vergaderschema voor de begrotingsbehande voorlegt. Naast de dagzittingen waarin over enige weken de algemene litieke beschouwingen aan de orde komen, vereist een prompte behan ling van de afzonderlike begrotingshoofdstukken dat de kamer een $p$ keer per week 's avonds opnieuw bijeenkomt.

Zo staan voor 10 november van 13.00-17.00 uur algemene beschoum gen en vanaf 20.00 uur Hoofdstuk III op de planning. "Ge weet wat dreigt bij Hoofdstuk III [buitenlandse zaken]", schrijft Colijn op 13 okto met een dringend beroep op Ruys, "... dan zilin de Alg. Beschouwing 
nog niet afgeloopen en zou $\mathrm{k}$ wellicht schorsing der beraadslagingen moeten vragen nog vöor de Regeering aan het woord was geweest. lk zou het op hoogen prijs stellen, indien ge de zaak zoo zoudt kunnen regelen dat een conflict niet ontstaat vóór de Alg. Beschouwingen geëndigd ziln. ${ }^{\text {"4 }}$ Als een kamervoorzitter die strikt onpartijdig wenst op te treden, laat Ruys de avondvergadering van 10 november gewoon doorgaan. De behandeing van Hoofdstuk III loopt op wieltjes. Het is inmiddels over twaalven, de meeste kamerleden zin al weg, de tribunes zijn leeg, als de geachte afgevaardigde Kersten aan zilin ceterum censeo Romam begint. Net als in vorige jaren stelt deze staatkundig gereformeerde Cato bij amendement voor, de posten voor het gezantschap bil de paus te schrappen om zodoende een eind te maken aan de "... krenking van het Calvinistisch karakter van het Nederlandsche volk ..." 5

In een fel weerwoord spreekt Nolens ziln afkeuring uit over dit "... voor ons, Katholleken, ... uiterst grievend [voorstel]. In dle omstandigheden zullen wij bij aanneming van dit amendement ernstig moeten overwegen, of wij onze steun aan de begrooting van Bultenlandse Zaken kunnen geven. Wil zullen ook de vraag hebben te beantwoorden, of wil steun kunnen verleenen aan welk Kabinet dan ook, voortgekomen uit groepen aan welker medewerking de opheffing van dezen gezantschapspost zou zlln te wijten." 6

In de middagvergadering van 11 november komt het amendement in stemming en wordt met de steun van de linkerzijde en de christelljk-historische coalitiepartner aangenomen. Nog dezelfde middag dienen de ver katholleke ministers hun ontslag in. Enkele dagen later is het hele kabinet demisslonair.

Met Colijn I eindigt een proloog van record-korte duur. Pas veertien jaar later lukt het deze kopman een nòg scherpere tijd - van exact twee dagen - te zetten. Maar vóór het zover is, vraagt De Maasbode zich in november 1925 somber af: "met welke eendagsvlieg ons land nu gelukklg zal worden gemaakt." 7

\section{* Rechts coalitieverbond ter ziele}

Eén in de aanvaarding van de goddelijke openbaring als de grondslag van het politieke handelen, één in de afwijzing van de beginselen van de Franse revolutie, één als het gaat om de belangen van de vrije school, ja de drie partijen van de rechterzijde hebben "... lets ideëels met elkaar gemeen, maar daarom denken zij niet over alles gelijk. Overleg is dus nodig om het partij-inzicht de plaats te geven, die het tegenover het gemeenschappelijk, het algemeen belang toekomt ..." 8 
Het is achteraf beschouwd nogal zacht uitgedrukt wat $\mathrm{CHU}$-fractieleid Schokking enige jaren geleden tijdens de algemene politieke beschouwi gen verkondigde. Nu de antithese tot links als rechts bindmiddel nag noeg heeft afgedaan, kunnen de onderhuidse, onderlinge tegenstelling van de coalitiepartijen op geestelijk en politiek vlak zonder veel belemm ringen hun gang gaan. Dit verwijderingsproces wordt nog versterkt doc dat ook binnen de drie fractles middelpuntvliedende krachten verdeel heid zaalen over zaken als het tempo van de sociale hervormingen, omvang van de bezuinigingen en het defensieapparaat, de voortzetti van de coalitie...

De gezantschapskwestie is ten slotte de druppel die de emmer doet ove lopen. De coalitie wankelt en het zijn vervolgens de vrijzinnig- en socia. democraten die "die samenwerking tot schade van het land" het laats zetje geven door ditmaal - uit een puur politiek maar buiten de begrotir gelegen motief - "het op zich zelf weinig belangrijk" amendement te ste nen.

Wat nu ? Marchant weet er wel raad op: "Als het mis loopt, moet gil maar weer gaan zitten", voegt hij Ruys in de nacht van Kersten toe. ${ }^{9} \mathrm{D}$ Marchant toch ! Uitgerekend de man met de reputatie van "tombeur c ministres" will Ruys terug, die hil net een paar maanden "Goddank kw $\left|s^{\prime \prime}\right|^{10}$. Daar is geen pell meer op te trekken. Denkt deze veelzijdige, strij bare en om zijn bijtend sarcasme geduchte aanvoerder van de vrijzinnis democraten in de Tweede Kamer nu heus dat hij er als scherprechter va de coalitie zo gemakkelijk van afkomt?

Misschien, maar de prominente Hendrik Pieter staat bekend als behoorli ondoorgrondelijk, zó zelfs dat het voor zijn politieke vrienden ondenkba. is dat hij zich over een jaar of tien tot zoiets schandaligs zou lenen ... "

De vlleger van Marchant gaat echter niet op. $\mathrm{Hij}$ is het toch vooral die h op de coalitie gemunt heeft, en wat ligt dan méér voor de hand dan hér maar eens een formatiepoging te laten wagen?, luidt het advies van Ruy: Nolens en de nieuwe AR-fractieleider Heemskerk aan de koningin. Op 2 november is het zover: Marchant mag gaan werken aan een "parlementa kabinet". Zou het hem lukken een ook door Albarda - de opvolger va Troelstra - begeerd vrijzinnig-rooms-rood kabinet in elkaar te timmeren, $c$ is de RKSP daar niet klaar voor?

\section{* Ruys en de reorganisatie van de staatspartif}

Het rommelt in de RKSP. Voor het eerst sinds Herman Schaepman alle R kiesverenigingen in 1897 onder één banier bracht, openbaren zich in he 
begin van de jaren twintig de symptomen van ernstige polltieke verdeeldheid onder de katholleken. De massale eenheid van "alle katholieke burgers van elk(e) beroep, ambt, bedrijf en stand" gaat splijten en vertakt zich naar rechts en links.

Uiterst rechts begint, aldus historicus De Rooy, "het dwepen met de komende sterke man, die Nederland ult de impasse van de democratie redden moet. In wezen is het echter een poging om het wankelend kapitalisme een kans te geven zijn tegenstanders te ontwapenen." "iz Als exponent van deze ultrarechtse denkrichting meldt zich in 1922 de Nleuwe Katholieke Partij, die met haar program - reactionair en duf als haar oprichter, de Haarlemse notaris $R$. van Cranenburgh - overigens geen schijn van kans heeft bij de kamerverkiezing van dat jaar en vervolgens gerukloos verdwijnt.

Uit verzet tegen de verrechtsing van de RKSP stichten links-katholieken in 1922 een nieuwe partij, de RK Volkspartij, die in 1925 met één zetel in de Tweede Kamer komt en daarna ook maar een splintertje blijft.

Andere progressleve katholieken verenigen zich in de Sint Michaëbeweging, die de staatspartij van binnenuit grondig wil democratiseren door de klezers politiek te vormen en invloed te geven op het partijprogram en de kandidaatstelling. Als het aan prof. mr. J.A. Veraart en zijn Michaëlisten ligt moet de staatspartij zich losmaken uit het rechtse coalitieverband en zich met nieuw elan ontwikkelen van een partij van de gulden middenweg tot "de grote hervormingspartij voor het sociaal-economische". ${ }^{13}$

De hervormingseisen van Veraart c.s. stuiten aanvankelijk op grote weerstand van het partijbestuur. Dit had namelijk met instemming kennisgenomen van een brief van het episcopaat van 24 mei 1921, waarin de bisschoppen de partij opriepen de coalitie te bestendigen en in elk geval niet met de SDAP in zee te gaan. En in aansluiting daarop had de algemene bondsvergadering op voorstel van het bestuur op 13 mel 1922 een motie aangenomen waarin werd verklaard dat "een samenwerking ultsluitend van katholieken en sociaal-democraten op de grondslag van een coalitie of regeerprogram onder geen voorwaarde of beding in overweging kon worden genomen". ${ }^{14}$

Door bemiddeling van Joannes Aengenent, grondlegger van de Katholieke Sociale Actie en latere bisschop van Haarlem, komen partijbestuur en Michaël eind januari 1925 overeen samen een reorganlsatieplan te ontwerpen en dit vervolgens aan de algemene bondsvergadering voor te leggen.

De desbetreffende reorganisatiecommissie - eerst geleld door Koolen en na diens toetreding tot het kabinet-Colijn, naar zijn nleuwe voorzitter: de commissie-Ruys geheten - komt medio 1926 met voorstellen tot wijziging van de structuur van de RKSP. De "Algemene Bond van Rooms-Katholleke 
Rjjkskjeskringorganisaties in Nederland (R.K. Staatspartij)" verandert in 1926 van een statutaire confederatie van kiesverenigingen in een partij, de "R.K. Staatspartl]", waarvan niet langer verenigingen, maar individuen lid ziljn. De algemene bondsvergadering maakt plaats voor de partijraad, waarvan de fractieleider in de Tweede Kamer voorzitter is. "De RoomsKatholieke Staatspartij was eindelijk werkelijkheid geworden", schrijft Gribling. "mede dankzij de rebellie van Veraart [dle de partij in 1929 met ruzie verlaat], de verzoeningspogingen van Aengenent in overleg met Nolens en de wijze leiding van Ruys de Beerenbrouck." 15

De eerste partiliraad kjest Ruys op 22 oktober 1926 tot eerste voorzitter van de partj. Daar heb je als parlementariër met een vierdaagse werkweek toch ook alle tijd voor!

\subsection{Een intermezzokabinet}

Toegerust met een uitgekiend tactisch concept dat als lokaas moet dienen om Nolens aan de haak te slaan, zoekt formateur Marchant het katholieke viswater op: dat gezantschap daarginder is eigenlijk wel een goede zaak en mag van het beoogde kabinet rustig blijven! De gladde hengelaar vist echter achter het net, heeft kennelijk niet goed geluisterd naar de bitse woorden van Nolens in de nacht van Kersten. En daar komt nog bij dat de staatspartij sinds drie jaar vastzit aan een anti-SDAP-besluit, dat een - haar sterk door Rome en het Nederlandse episcopaat ontraden - apertura a sinistra uitsluit, zolang een opening naar links althans geen "uiterste noodzaak" is.

Exit Marchant. Vervolgens beweegt formateur De Visser zes weken lang hemel en aarde om het kabinet-Colijn met een compromisoplossing voor de gezantschapskwestie - de ambassadeur in Zwitserland zou het Vaticaan erbij moeten nemen - te redden.

Als. De Visser stukloopt op zijn eigen fractie, is de vrijzinnig-democraat $\mathrm{mr}$. J. Limburg aan de beurt om een extraparlementair kabinet te vormen. Dankzil allerlei hand-en spandiensten van Ruys, voor wie de terugkeer van het demisslonaire kabinet na de mislukte poging van De Visser een gepasseerd station is, komt politiek outsider Limburg een heel eind: op $26 \mathrm{fe}$ bruari 1926 vindt zowaar de constituerende vergadering plaats van een kabinet, bestaande uit vier linksen, vier rechtsen en de "neutrale" Van Karnebeek. Tòch ketst de formatle op het laatste moment nog af. Op de gezantschapskwestie uiteraard. Het nieuwe kabinet zou namelijk de kamer voorstellen het gezantschap te handhaven. maar plots ziet kandidaat-minister De Geer beren op de weg en kiest de vlucht. 
"Toen kwam het moment, waarin ik het als een lafheid voelde, in deze uiterste noodzaak, niet over mijn bezwaren heen te stappen. Ik vermoedde de martelingen "die mij dat brengen zou. Maar lemand moest zich toch geven ... al schenen voor hem de moeilijkheden grooter dan voor anderen ... Ik heb toen besioten te aanvaarden." 16

Door toedoen van deze man - vol zelfbeklag en zonder de zelfverzekerdheid van zijn voorganger weliswaar, maar wèl ervaren in "stil" (In-)formeren - heeft Nederland op 8 maart 1926 opeens een nieuw kabinet. Een extraparlementair, dat als "intermezzokabinet" volgens zijn schepper en premier De Geer meteen het veld will ruimen, zodra zich een parlementaire meerderheidscombinatie aandient.

Een dergelijk politiek alternatief blijft evenwel uit. En in plaats van een Intermezzo van korte duur maakt het nagenoeg kleurloze kabinet-De Geer een rit die het met wisselende steun van rechts en links en tot aan de kamerverkiezing van 1929 uitzit.

\section{* Kosmopolieten in naam}

Na een crisis van bijna vier maanden waarin het conflict over het gezantschap verder oploopt, vraagt het nieuwe kabinet de kamer zich, los van politieke overwegingen, nogmaals over dit hot item uit te spreken. Zelf wil het kabinet in dezen een neutraal standpunt innemen en geen politieke consequenties aan het kamervotum verbinden. $\mathrm{Bij}$ de hervatting van de behandeling van Hoofdstuk III van de begroting op 19 maart 1926 komt het gezantschap opnieuw in stemming en besluit de kamer met 48 tegen 41 - katholieke en antirevolutionaire - stemmen tot opheffing van deze diplomatieke post. En alweer houdt verlicht Nederland de rest van de wereld een spiegel voor!

Eind oktober 1926 komt een andere twistappel in de Tweede Kamer op tafel: het verdrag met België. Het voorstel lokt felle discussles uit, waarbil vrijwel elke fractie haar pleitbezorgers vóór en tégen telt. Alleen de $\mathrm{CHU}$ en de klassieke voorvechters van de vrijheid van handiel en verkeer vormen één gesloten front tegen de "protectionistische" maatregelen ten bate van Antwerpen. Uiteindelijk wurmt Van Karnebeek het traktaat met 50 tegen 47 stemmen door de Tweede Kamer.

Ik stelde me de Hollander voor "als een min of meer cosmopolitisch denkend burger, met wereldkennis, trots op zijn durf en zijn ondernemingsgeest, hem bijgebracht door een zeker glansrijk verleden, [maar ontmoet nu] een heel ander type, een kleinmoedige, kleinburgerlijke zlel" ${ }^{17}$, verzucht sociaal-democratisch kamerlid Willem Vliegen over zoveel agitatie 
tegen het verdrag. Ja, deze Limburger van oorsprong heeft makkelijk $p$ ten: die heeft op zijn balkon in Gulpen wél ooit Europa zien liggen!

De uitslag van de stemming in de Tweede Kamer heeft tot gevolg dat oppositie tegen het verdrag fel oplaait. Pressiegroepen komen in actie de Eerste Kamer over te halen het verdrag te verwerpen. "De intimidat waaraan dit lichaam bloot staat, neemt weerzinwekkende afmeting aan", klaagt Van Karnebeek, die zilin levenswerk ziet instorten. ${ }^{18}$ De sen toren zijn ditmaal een en al oor voor de "rechtsovertuiging van het vo als zij op 24 maart 1927 met 33 tegen 17 stemmen hun veto uitsprek over het traktaat met België. Voor Van Karnebeek is daarmee de maat $v$ $\mathrm{Na}$ twee opeenvolgende afwijzingen van "zijn" buitenlands beleid nee hij voorgoed afscheid van de politiek.

Buiten de afhandeling van de twee onderdelen van het regeerprogra waar weinig eer aan te behalen viel, komt het kabinet ook toe aan de $g$ plande wetgevende arbeid. Zo brengt minister dr. J.R. Slotemaker de Bruine in de wet op de collectieve arbeidsovereenkomst van 24 decemb 1927. Staatsblad nr. 415, een wettelijke regeling van bij individuele beidsovereenkomsten in acht te nemen algemene arbeidsvoorwaarden stand. Twee jaar later bewerkstelligt dezelfde minister een ingrijpende he ziening van Talma's ziektewet 1913, die na een langdurig gehakketak ov de uitvoeringsorganisatie - van rijkswege (door de Raden van Arbeid) bedrijfstakgewijs - het bedrijfsleven uiteindelijk de viije keus laat.

En vlak vóór de kamerverkiezing van 1929 zorgt De Geer in zijn hoedani heid van minister van financiën nog voor een nieuwe regeling van de nanciële verhouding tussen rijk en gemeenten. Ter vervanging van hun komstenbelasting ontvangen de gemeenten voortaan een uitkering uit $e_{1}$ door het rijk beheerd gemeentefonds, terwijl zij bovendien de beschildki krligen over de opbrengst van de personele belasting en voor driekwe ook van de grondbelasting.

Als deze nieuwe regeling op 15 juli 1929 in het Staatsblad (nr. 388) ve schijnt, staan de ministerportefeuilles al veertien dagen ter beschikking vi de koningin. En zo zet De Geer na een intermezzo van ruim drie jaar ku dig en wel de kroon op zijn werk, dat hem de vermoede martelgang b spaarde.

\subsection{De kabinetsformatie van 1929}

Na een lauwe verkiezingsstrijd sluit de stembus op 3 juli 1929 met ee nagenoeg zelfde uitslag als vier jaar geleden. De RIKSP handhaaft zich $c$ 
30, de SDAP op 24, de CHU op 11 en de VD (vrijzinnig-democraten) op 7 zetels, terwijl de AR en de liberalen (de voormalige Vrijheidsbond) elk één zetel verliezen en terugzakken naar $\| \mathbf{2}$, resp. 8 zetels. Met één zetel winst voor de partij van dominee Kersten is klein rechts - de SGP (3) en de Hervormd (Gereformeerde) Staatspartij (1) - thans met 4 zetels in de kamer vertegenwoordigd.

Groot rechts is opnieuw in de meerderheid en "... nu is het alleen zaak .... te zorgen, dat er kome een Christelijk kabinet - niet een Kabinet van water-en-melk-Christendom, maar een positief Christelijk Kabinet ...", wenst Van Wijnbergen Ruys met diens mooie verkiezingsresultaat toe. ${ }^{19}$

Van Wijnbergen heeft geen reden tot klagen als op 6 jull eerst kamervoorzitter Ruys en op 9 juli vervolgens de drie rechtse fractieleiders Nolens. Heemskerk en Schokking de koningin in hun adviezen de formatie van een rechts kabinet, steunende op de drie rechtse partijen, aanbevelen. Wel schuilt er in Schokkings advies een christelijk-historisch addertje onder het gras: "... samenwerking van de rechtsche groepen, maar eene in vrijheid..." 20

$\mathrm{Na}$ de aansluitende raadpleging van Albarda en Marchant - beiden adviseren tot een parlementair kabinet "op democratische grondslag, wat staat voor: met onze deelname ! - en de "extraparlementair" georiënteerde liberaal mr. A. van Gijn, kan de koningin de balans gaan opmaken.

De verkiezingsuitslag en het merendeel van de adviezen wijzen in de richting van een rechts kabinet. Maar dàt deden die in 1925 óók en dat bleken toen niet zo'n betrouwbare indicaties te $z$ ljn, herinnert Wilhelmina zich nog!

Sindsclien is het echter hommeles. De Vaticaankwestie was er debet aan dat de onderlinge verhouding van katholieken en christelijk-historischen tot het vriespunt daalde. En in de nasleep van die affaire kwamen ook de $A R$ en de CHU scherp tegenover elkaar te staan toen De Geer met zijn intermezzokabinet de doodsteek toebracht aan het kortstondige bewind van Colijn. Er zal dan ook een conflictbezweerder, een bruggenbouwer aan te pas moeten komen om de drie grote rechtse partijen bijeen te brengen. lemand met veel krediet bij het gespleten trio, kortom: een synthetisch figuur, en dan vallen De Geer en Colijn sowleso af I

Op 12 jull ontbiedt de koningin haar uitverkorene op Huis ten Bosch. Ruys ontvangt de opdracht "een kabinet, steunende op de rechterzijde" te formeren. Drie dagen later ligt zijn concept-regeerprogram al bij de drie fracties in de bus. Op 19 juli heeft de formateur de reacties binnen. De kamerclubs van de RKSP en de AR zijn bereid met een kabinet van zijn makelij in te stemmen.

De CHU-fractie echter weigert zich vooraf te binden aan een regeerpro- 


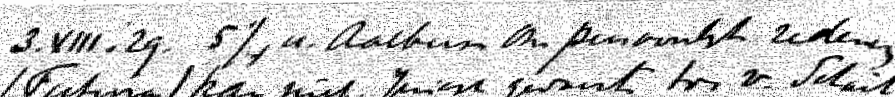

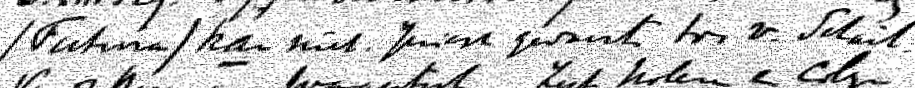

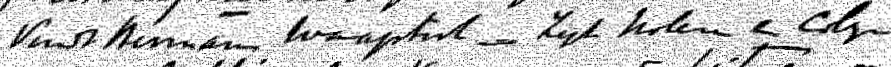

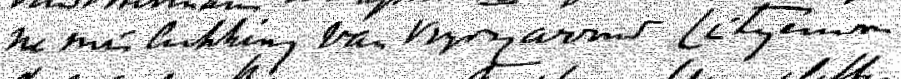

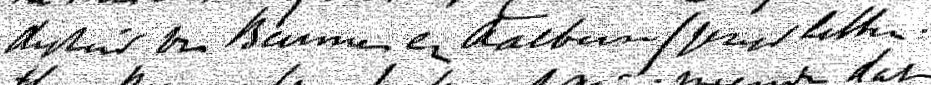

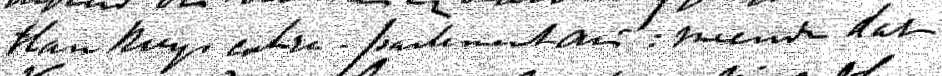

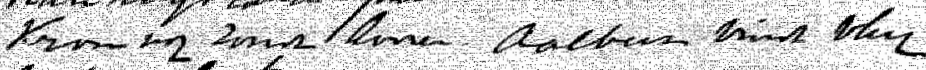
$0+1,2+2$

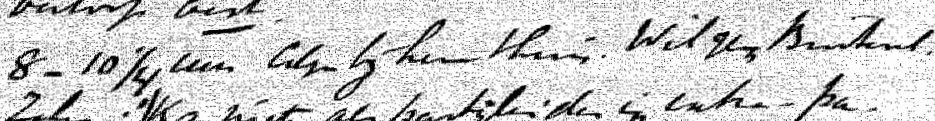

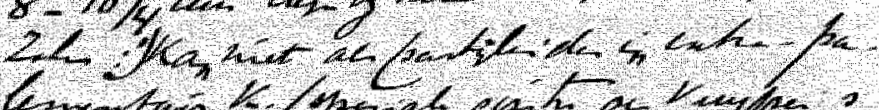

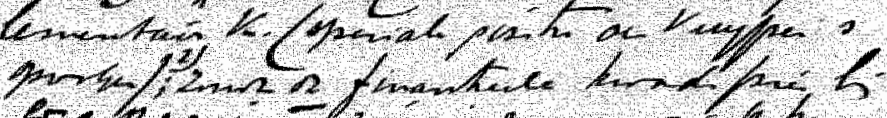

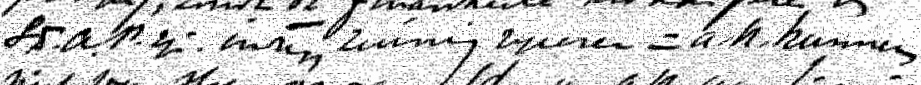

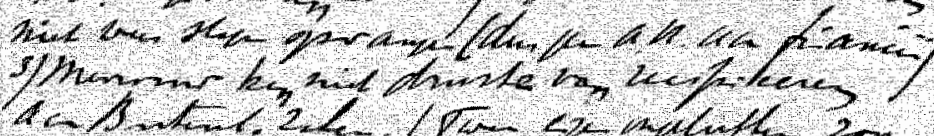

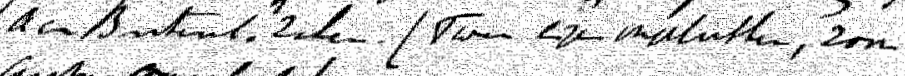

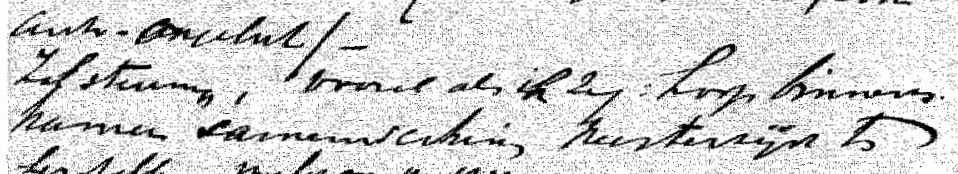

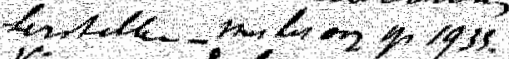

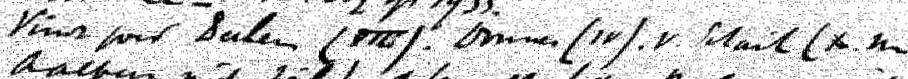

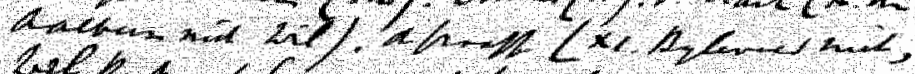

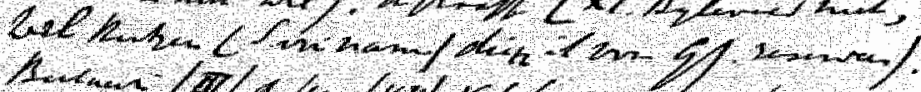

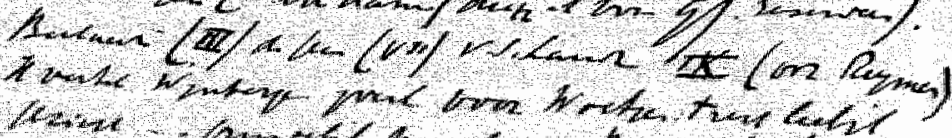

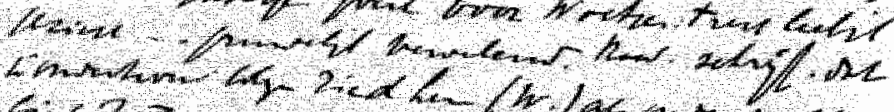

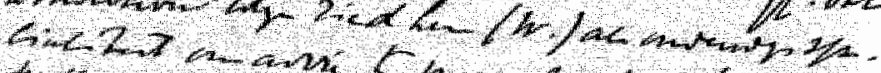

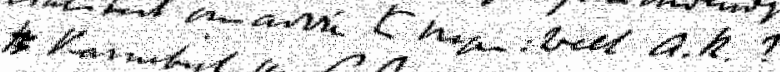

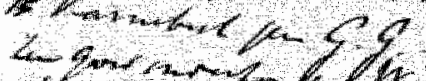

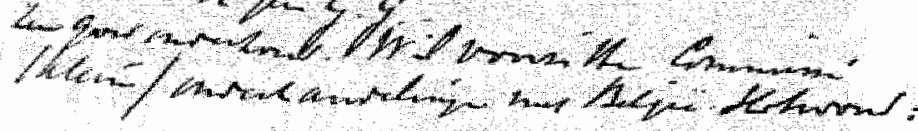

Ruys' aantekeningen over de (extraparlementaire) kabinetsformatie op 3 augustus 1929: "... Aalberse [kan] om persoonilke redenen niet ... [maar vindt vlug verloop best ... Colin ... kan net als partilleider in extra parlementair $K$....., zoudt de finantieële "kwade pier bil SDAP ziin ..." 
gram, maar zal het kabinet wel steeds bij voorkeur steunen... Hier herhalen zich de gevleugelde woorden van Lohman tot Kuyper in 1901: "Mijne vrienden en ik zullen dus onzen loyalen steun verleenen aan dit Kabinet, ... doch als vrij man. Aan niemand heb $\mathrm{kk}$ mijn vrijheid verpand ... ${ }^{21}$ Maar ja, dát was in de gloriejaren van de coalitie, toén kon je nog regeren zonder vaste afspraken met de fracties !

De opstelling van de CHU-fractie is een lelijke tegenvaller voor Ruys, die vervolgens de fracties van de AR en de RKSP de vraag voorlegt of zij een parlementair kabinet in de gegeven omstandigheden nog zien zitten. Het antwoord van beide kamerclubs is ontkennend en als de formateur daarna in overleg met de drie fractieleiders samen, de CHU niet tot andere gedachten kan brengen, weet hil hoe laat het is. Ruys staat niets anders te doen dan op 3 augustus zijn opwachting bij de koningin te maken - ditmaal voor de variatie op Soestdijk, waar zij de verjaardag van haar moeder Emma viert - om haar te berichten dat zijn missie is mislukt.

De koningin luistert naar nieuws waar zij na alle tussenrapportages van Ruys over de formatieperikelen al serieus rekening mee hield. Een meevaller is wel dat de drie clubs geen moeite hebben met een nieuw premierschap van Ruys. Nou, dan kan zij de bezoeker wel de vervolgopdracht meegeven, een extraparlementair kabinet te formeren. ${ }^{22}$

Voor Ruys komt het er nu opaan het ijzer te smeden terwijl het nog heet is. Geen van de grote confessionele fracties is immers tegen een rechts kabinet onder zijn leiding, en met de nieuwe opdracht op zak hoeft hij met die drie kamerclubs ook niet langer te soebatten over een regeerprogram.

$\mathrm{Na}$ al het voorwerk en overleg in de eerste formatieronde wil Ruys nu zo snel mogelijk een team van herkenbaar rechtse signatuur bil elkaar krijgen. Direct na thuiskomst van Soestdijk polst hij Aalberse, vervolgens Colljn, maar beiden zijn niet beschikbaar voor een ministerspost. Aalberse toont overigens alle waardering voor de vlotte aanpak van de formateur, over wie hij nog maar een week geleden aan de hoofdredacteur van De Maasbode schreef: "Ruys wil per se slagen, en juist daardoor begaat hil domheden ..." 23

Achterklap, zoveel is zeker, en wat heet dom ? In elk geval lukt het de formateur twee vooraanstaande CHU-ers - de demisslonaire ministers De Geer en Beelaerts van Blokland - voor zijn kabinet te strikken. En daar blift het niet bij. Na het uitgaan van de kerk waar Ruys dagelijks naar de mis gaat, komt hij op straat mr. J. Donner tegen, die zich op de flets naar zijn ministerie spoedt. En passant gaat ook de bekwame antirevolutionaire bewindsman op de vraag: "Ik kan wel op je rekenen, hè [jan] ?" 24 , ak- 
koord met deze spontane ledenwerving.

Met behulp van een netwerk van persoonlijke relaties heeft Ruys zijn kabinet op 9 augustus compleet. Naast De Geer (financlën). Beelaerts (buitenlandse zaken) en Donner (justitie), die op hun post blijven, telt de ministerspioeg de nieuwelingen $\mathrm{mr}$. J. Terpstra ( $A R_{\text {; }}$ onderwijs, kunsten en wetenschappen), dr. L. N. Deckers (RK; defensle), mr. P.J. Reymer (RK; waterstaat) en mr. T.J. Verschuur (RK; arbeid, handel en nijverheid), alsmede de oude bekenden S. de Graaff (partijloos; ook al van 1919-1925 minister van koloniën) en Ruys (binnenlandse zaken en landbouw).

Al wle intussen op de hoogte waren van het verloop van de extraparlementaire formatie, de drie rechtse fractieleiders niet. Pas als Ruys zijn opdracht helemaal af heeft, laat hij hun het resultaat van de gedane arbeid weten. Nolens is zeer ontstemd over de werkwijze van Ruys, die hem volledig onkundig liet van de gang van zaken. In de fractievergadering van 17 september kan de monselgneur dan ook niet nalaten te benadrukken "... dat wil thans hebben een extraparlementair Kabinet, voor welks optreden en samenstelling de Kath. fractie geenerlel verantwoordelijkheid draagt. De formateur heeft ook met den $\mathrm{Vz}$. noch mondeling noch schriftelijk ten deze eenig overleg gepleegd." 25

Het loopt al een tijd niet soepel tussen de twee katholieke voormannen. Eerst was het Nolens die de ander in 1925 wegpromoveerde ten gunste van Colijn, toen had Ruys buiten de een om in 1926 en nu wéér in 1929 de hand in de totstandkoming van een extraparlementair kabinet. En zo waren er de laatste jaren wel méér ergernissen die de toch al altijd koele verhouding van elkaars tegenpolen - de afstandelijke en zakelijk-intellectuele Nolens versus de toegankelijke en intuïtieve Ruys - vertroebelden. Tot het bittere eind toe ! 


\section{HET DERDE KABINET-RUYS DE BEERENBROUCK (1929-1933)}

\subsection{Inleiding}

Er is geen wolkje aan de lucht als zes door de koningin op Soestdijk beëdigde ministers op 10 augustus 1929 samen met de drie aanblifvende collega's hun taken opvatten.

Nederland vaart nog steeds redelijk wel. De economie is gezond, de financiën zijn in orde en van politieke of maatschappelijke beroering is nauwelijks iets te bekennen. Het kabinet-Ruys III steekt zogezegd van wal onder een gelukkig gesternte. Als de voortekenen tenminste niet bedriegen...

Begin oktober 1929 raast plotseling een hevige storm over Wall Street. De vloedgolf van wilde speculaties op de beurs van New York slaat om in een stormvloed van panische verkoop van effecten. Op 24 oktober stort de beurs in. De "motor van de economie" in de Verenigde Staten slaat af. Op de mokerslag die het krediet- en betalingsverkeer treft, volgt ginds een kettingreactie die de productie verlamt, massale werkloosheid teweegbrengt, de koopkrachtige vraag uitput, de prijzen doet kelderen en ten slotte het economische leven totaal ontwricht.

Met gepaste belangstelling neemt men ook hier kennis van hetgeen aan de overzijde van de Atlantische Oceaan gebeurt. Goed, laat een economische crisis dan naar beproefd staatshuishoudkundig inzicht zich niet meer kunnen voordoen in een geordende maatschappij als de onze, maar een dalende welvaart in een land als Amerika is altijd nog een conjuctuurschommeling die, alhoewel niet zorgwekkend, tòch zorg eist, ook al zal de bui wel overwaaien ...

Of die bul nu wel of niet in figuurlijke zin overwaaide, hoe men dit ook opvat, de werkelijkheid is dat zich in de loop van 1931 een diepe crisis in ons land begint af te tekenen. De agrarische sector, vervolgens ook de scheepvaart en de industrie raken in grote problemen, die het kabinet noodzaken de ene na de andere steunmaatregel te treffen. Het blijkt een gevecht tegen de bierkaai: het crisisbeleid kan niet verhinderen dat het werkloosheildscijfer in hoog tempo van 140.000 ultimo 1930 oploopt tot 400.000 eind 1932.

Terwijl de economische crisis wereldwijd om zich heen grijpt en in 1932 


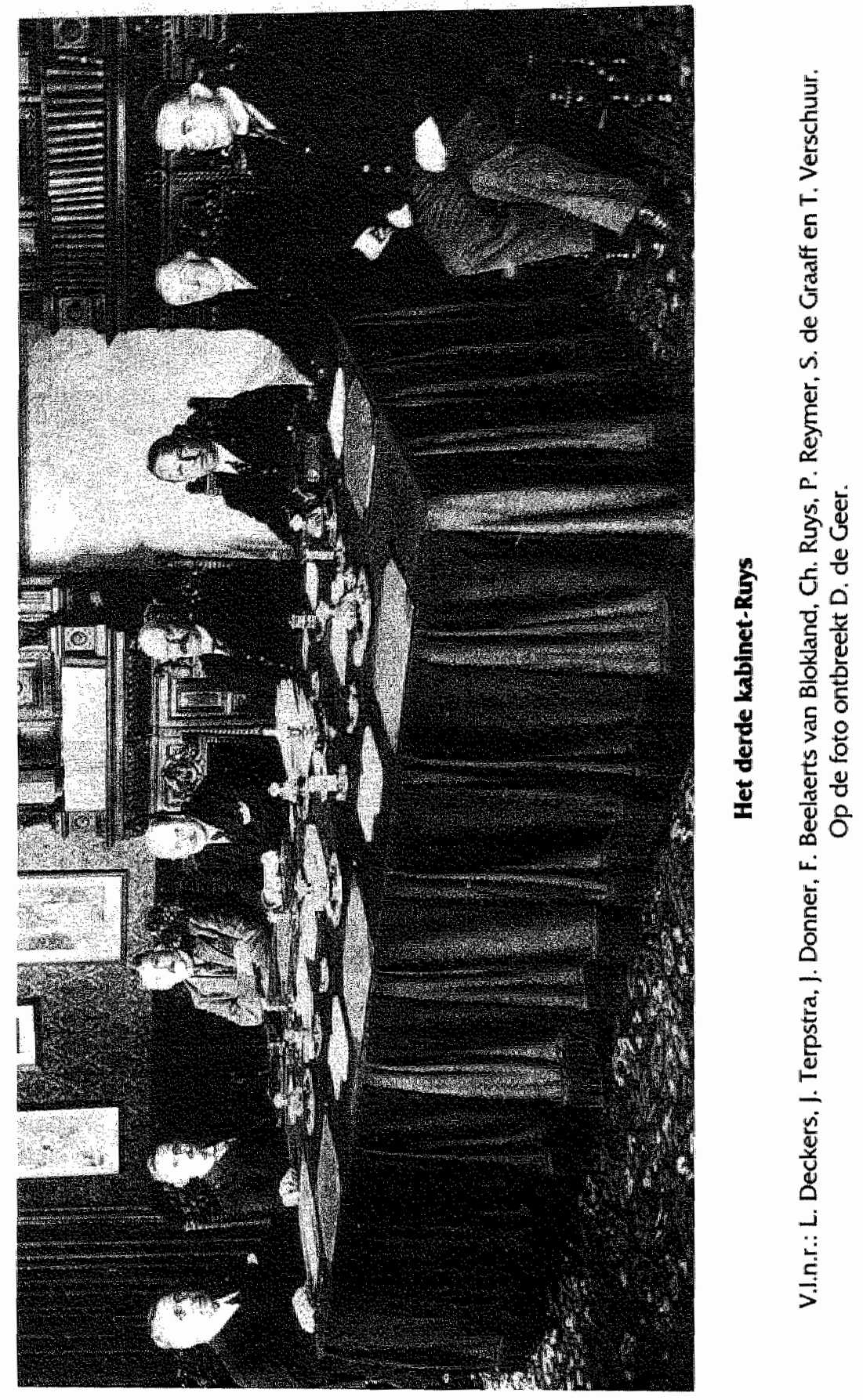


haar dieptepunt bereikt, stijgt de ontwapeningsgedachte intussen tot grote hoogte.

In de jaren 1932-1933 werkt de Volkenbond te Genève druk aan een ontwapeningsverdrag dat moet voorzien in een vreedzame regeling van de internationale geschillen, alsook in een reductie van de legers van Frankrijk en Engeland tot minder dan de helft van hun vredessterkte. De ontwapeningsconferentie gaat de goede kant op, totdat het sinds 1919 gedemilitariseerde Duitsland categorisch erkenning eist van zljn recht op herbewapening en de conferentie zich daarop toegeeflijk laat meeslepen door het beginsel van "gelijkheid tussen staten". Reichskanzler Hitler kan nu voort met zijn Kampfen heeft de Volkenbond niet meer nodig.

Ruys is dus voor de derde maal premier. Zo kan dan nu "de edelman die werkt voor het volk" in het stabiele klimaat van 1929 zijn verkjezingsbelofte gaan waarmaken.

Het eerste bewindsjaar verloopt voorspoedig. Dan doemt, na een kortstondige stagnatie in de economische groei, een crisis op, die zlch snel uitbreidt en kabinet en bedrijfsleven volledig verrast. Maar daar blijft het niet bij. Als een voorbode van de "nieuwe orde" vertonen zich in het najaar van 1932 voor het eerst rumoerige bendes marcherende bruin- en zwarthemden op straat. Enkele maanden later slaat de bemanning van De Zeven Provinciën aan het muiten en gaat er in de haven van het Atjehse Kota Radja met die oorlogsbodem vandoor. Een paar dagen nadien komt het kabinet met de Tweede Kamer in botsing over een ontwerp tot wi|zlging van de rechterlijke organisatie.

"Moeten we nu wéér vier jaar naar door ambtenaren opgestelde verhalen luisteren, die hij vel na vel voorleest ?" ', verzucht een uit ervaring puttende Hendrik Tilanus ( $\mathrm{CHU}$ ) bij het aantreden van zijn politieke vriend Ruys. Inderdaad, de premier verstaat de "kunst" zijn gehoor danig te vermoeien. Maar al zijn de tijden die dit kabinet tegemoet gaat moeilijker dan oolt tevoren, de geheide overlevingskunstenaar komt ook ditmaal - vrijwel - de hele kabinetsperiode door I

\subsection{Niet zorgwekkend, wel zorgeisend}

Met de gebruikelijke uiteenzetting van de hoofdlijnen van het regeringsbeleid voor de komende zittingsperiode presenteert het nieuwe kabinet zich op de derde dinsdag van september 1929 aan de verenigde vergadering der Staten-Generaal. De troonrede is lang, maar waar men bi] de presentatie van dit ministersteam van rechtse samenstelling vergeefs op 
wacht is op een beginselverklaring, waarmee een kabinet te kennen geeft onder welke vlag het gaat varen.

Zoals vastligt in het regeerprogram voor de wetgevende periode 1929. 1933 stelt het kabinet zich tot taak in het eerste zittingsjaar een reeks soclale maatregelen - met name op het gebied van de arbeidsbemiddeling. de sociale verzekering en de bedrifsraden - te treffen en daarnaast aan enkele andere belangrijke onderdelen van de wetgevingsparagraaf - waaronder de herziening van de gemeentewet, de winkelsluiting en de ambtenarenrechtspositie - uitvoering te geven.

Voorts wil het kabinet de Volkenbond krachtig steunen in diens plannen tot vreedzame regeling van de internationale geschillen, vermindering van de bewapening en opheffing van de belemmeringen in het internationale handelsverkeer.

Vindt de troonrede de economische situatie van ons land in het algemeen bevredigend, oppassen is de boodschap zodra het behoud van het financlële evenwicht de revue passeert. De begroting voor 1930 mag dan wel een overschot van $f 9$ miljoen vertonen, dit neemt echter niet weg dat de toestand van 's Rijks financiën volgens de milloenennota "zij het niet zorgwekkend, toch in hoge mate zorgeisend" ${ }^{2}$ is. Regeren is immers vooruitzlen, maant schatkistbewaarder De Geer, en daartoe moet hij in zijn meerjarenraming rekening houden met een enorme lastenverzwaring vanaf $1931 \ldots$ als zijn financiële-verhoudingswet rijk-gemeenten in werking treedt.

\section{* Et/ketten opplakken}

Het was op maandag 22 juli 1929 dat Ruys de hele dag druk in de weer was om van een halsstarrige $\mathrm{CHU}$-fractie alsnog vaste steun voor zijn parlementair kabinet los te peuteren, en er 's avonds een ongetekend ingezonden stuk in De Nederlander verscheen: "Sommigen schijnen te meenen, dat het verschil tusschen een parlementair en een extra-parlementair kabinet is, dat bij het eerste het regeeringsprogram door bepaalde Kamerfracties goedgekeurd is en zij zich tot het verleenen van steun aan dat program hebben verbonden, terwijl bij het extra-parlementair kabinet deze vooraf gelegde band ontbreekt. Deze opvatting is onjuist. Het verschil tusschen een parlementair en een extra-parlementair kabinet Is, dat het eerste zilin steun zoekt bij] een vaste meerderheid in de Kamer, terwijl het laatste geen bezwaar heeft voor verschillende onderwerpen " die het ter hand neemt, telkens wisselende meerderheden te vinden ... Wie dan ook voor een vooraf-gelegden band tusschen het Kabinet en de fracties pleit, komt steeds op voor een bepaald soort van een parlementair 
Kabinet ... In het verleden zlinn er vele parlementaire Kabinetten geweest ... Waarbij de eisch van voorafgaande goedkeuring van het Regeeringsprogram door de fracties, waarop het kabinet steunde, niet werd gesteld ... Men zal dan ook goed doen, het begrip "parlementair Kabinet" niet enger te trekken dan historisch te rechtvaardigen is ..." 3

Zou nu óók de formateur maar de mening van die anonieme stukjesschrijver - achter wie De Geer zich schuilhield - zijn toegedaan, dan had hij even later niet hoeven te stoppen met zijn parlementaire formatiepoging en had hij zich bovendien over het al dan niet extraparlementaire karakter van zijn derde kabinet een discussie van uiterst steriel gehalte met beide kamers kunnen besparen.

Onomwonden geven de vertegenwoordigers van de drie christen-democratische fracties in het voorlopige verslag van de bevindingen van de Tweede Kamer over het eerste hoofdstuk van de staatsbegroting voor 1930 te kennen dat hun clubs geen enkele verantwoordelijkheid aanvaarden voor het optreden van dit geheel bulten hun medewerking om gevormde kabinet. Extraparlementair, zoals zij het noemen, had het niettemin een stichtelijke beginselverklaring in de troonrede niet achterwege mogen laten. Toe maar! Toch is het kabinet vervolgens niet te beroerd om bij memorie van antwoord te verklaren dat het een christelijke politiek in overeenstemming met de beginselen van de rechterzijde zal voeren.

Zo zitten dan na een geslaagde extraparlementaire formatiepoging twee heren in het kabinet - de een zetelt in het Torentje, de ander op de Kneuterdijk -, die onderling van mening verschillen over de vraag: in what kind of business they are. Marchant zal het hun in het kamerdebat eens haarfijn uit de doeken doen. Een kabinet is parlementair, zo ontvouwt de vrijzinnig-democraat, als het een vertrouwensband heeft met - een meerderheid vormende - geestverwante fracties in de Tweede Kamer, dan wel als het kan rekenen op de vaste steun van een "working majority" van n" importe welke (andere) samenstelling. Of de formateur van een parlementair kabinet de fracties waarvan hij "het moet hebben", al dan niet bij de uitvoering van zijn opdracht betrekt, is louter een kwestie van werkmethode, doch is van geen enkele betekenis voor het karakter van het kabinet. Van welk type een kabinet is dat niet aan een van de door hem genoemde criteria voldoet, laat de belerende afgevaardigde overigens geheel in het midden. Voor Marchant is Ruys III simpelweg een parlementair kabinet, omdat het dezelfde kleur vertoont en/of dezelfde praktische doeleinden nastreeft als de meerderheid van de Tweede Kamer. Zo heet bil hem zelfs het vrijzinnige minderheidskabinet van de "op-en-top-extraparlementaire for- 
mateur" "Cort van der Linden parlementair, ofschoon dat een elk-wat wils-politiek moest voeren om de kamer gaandeweg voor zijn pacificatie doelstelling te winnen.

Anders dan Marchant zlet Ruys wèl een duidelijke relatie tussen de wijz van formeren en het eindresultaat. Gaven het samenspel van hem met $d$ top van de drie rechtse fracties in 1918 en het regeerakkoord van 192 aan zilin toenmalige kabinetten een parlementaire basis, nu in 1929 heel ziln sollstische optreden tot gevolg dat de hele rechterzijde weigert had vingers te branden aan zijn derde kabinet.

Ruys spreekt ult ervaring als hij wijst op de nauwe samenhang van d gevolgde formatiemethode en de grondslag van een kabinet, maar $z$ onweerlegbaar extraparlementair wil hij zijn nieuwe kabinet nu ook wee niet noemen: "... niemand [heeft] coit den landmeter ontmoet, die he heeft bestaan met de nauwgezetheid, zijn vak eigen, de grenzen te trek ken tussen een parlementair- en een extra-parlementair kabinet ..." 5

$\mathrm{Na}$ deze relativerende woorden van de premier haasten de fractieleider van groot rechts zich te verklaren dat niemand mag denken met een nol maal rechts kabinet van doen te hebben. Door - onbezonnen genoeg zonder enige vorm van overleg met hen te formeren, is niemand ander dan Ruys - met de rest van zijn ploeg natuurlijk - verantwoordelijk voor $d$ kabinet, spreken Nolens, Colijn en Schokking in koor. Nochtans ontbreel het in hun fracties niet aan enige welwillendheld jegens dit kabinet, al het dan puur extraparlementair, volgens Colijn, althans niet zuiver parle mentair, naar de mening van Schokking.

Nolens heeft inmiddels schoon genoeg van al dat getwist over het karak ter van het kabinet. Dat is maar apekool en tijdverspilling voor een ma van de grote lijn zoals hij. Als het dan per se moet, mag het kabinet va hem wel rechts-extraparlementair heten, maar liever laat hij het zinloz etiketten opplakken over aan juristen met een ongebreidelde rubricerings hartstocht.

Zo"n jurist is de kersverse senator Roelof Kranenburg (VDB) bepaald nie Een kabinet is parfementair of het is niet, dát is de hele kwestie, vat dez hoogleraar staatsrecht in Leiden zijn Eerste-Kamerbetoog in de trant va Shakespeare samen. Sinds 1868 wil immers de ongeschreven regel va staatsrecht ", dat elk kabinet voor zijn aanblijven afhankelijk is van he vertrouwen - de gedoogsteun geldt daarbij als ondergrens - dat het daat voor van de volksvertegenwoordiging krijgt.

Ruys sputtert nog wat tegen "vindt zo elk typologisch onderscheid verlo ren gaan. Maar het is nu ook weer niet lets orn je langer druk over te ma ken. Mijn kabinet is in elk geval "... rechtsch, vanwege zijn beginseler zijne leden, zijn program ... [en wil] het verboden terrein van beginselvra 
gen niet onbetreden laten ..." ${ }^{7}$ En dan moet later maar blijken of het parlement daarvan gediend is, om in de geest van Kranenburg te spreken.

\subsection{Een goed begin}

Het heeft een lange voorgeschiedenis, maar nu staat echt bovenaan de lijst van actiepunten voor het eerste zittingsjaar een ontwerp van wet tot regeling van de ambtenaarspositie. Al in de negentiende eeuw vonden Thorbecke en Krabbe dat de wetgever hier in het belang van een deugdelijke overheidsorganisatie en ter bescherming van de ambtenaren tegen willekeur een daad moest stellen.

Kuyper deed de aftrap met zijn (anti-)stakingswetten van 1903, waar de meeste ambtenaren natuurlijk niet op zaten te wachten, en zette vervolgens de totstandbrenging van een algemene wettelijke regeling van het ambtenarenrecht op touw. Het ontwerp dat daaruit voortkwam, belandde in een la op justitie. En zo verging het uiteindelijk ook een in 1920 bij de kamer ingediend en in 1928 weer ingetrokken ontwerp-Heemskerk, dat was voorbereid door een staatscommissie onder voorzitterschap van de liberaal Dresselhuys.

Bevatte dit ontwerp een regeling van zowel materieel als formeel ambtenarenrecht, het ontwerp waarmee Donner in het najaar van 1929 voor het parlement verschijnt, regelt nog slechts de rechtspraak in ambtenarenzaken en laat de vaststelling van arbeidsvoorwaarden over aan het overleg van daartoe aangewezen overheidsorganen met de ambtenarenorganisaties.

De fracties van de SDAP en de VDB in de Tweede Kamer hebben er grote moeite mee dat het parlement zich volgens het ontwerp niet zou mogen bemoeien met de materiële rechtspositie van de ambtenaren. Dan kan de regering straks weer allerlei kunstjes uithalen, verduidelijkt Marchant. Vergeefs tracht de oppositie het tij met een motle te keren, waarna de Tweede Kamer - weldra gevolgd door de Senaat - de wet zonder hoofdelijke stemming aanvaardt.

Op 12 december 1929 verschijnt Donners ambtenarenwet in het Staatsblad (nr. 530). Enkele decennia later tekent diens zoon Andreas bij die regeling aan "... dat het openbaar belang zekere elgenaardigheden in de inrichting van de openbare dienst vordert. Niet de minste daarvan is, dat door de afzonderlijke positie aan het bestuurspersoneel het besef wordt ingescherpt van zijn hoge roeping en de ambtelijke "ethos" mede wordt levend gehouden ..."

Waarvan akte! 
Het was Aalberse die Ruys bij diens tweede formatiepoging in 1929 adviseerde Verschuur voor de portefeuille van arbeid, handel en nijverheid te vragen. Met deze voorzitter van de Raad van Arbeid in Breda treedt een politiek zwaargewicht aan, dat er de komende jaren in slaagt alle over diverse ministeries verspreide economische winkeltjes met vaste hand samen te bundelen tot één ministerie van economische zaken - en arbeid.

Laat het nu heel toepasselijk net de winkelsluitingswet zijn die Verschuur bij ziln eerste confrontatie met het parlement moet rondmaken ! Het voorliggende wetsontwerp komt tegemoet aan de wensen van de middenstand, die in grote meerderheid een verplichte zondagssluiting als de enige mogelijkheid beschouwt om de onderlinge concurrentiepositie te normaliseren en de per I Januari 1930 geldende arbeidsduurbeperking van het winkelpersoneel in de bedrijfsvoering in te passen.

Tot zover maken alleen de liberalen bezwaar tegen het wetsontwerp, dat zij zlen ais een aantasting van de vrijheid, blijheid van de ondernemer - en speclaal van diegene die daar altijd al zo goed raad mee wist.

Orthodox-rechts begint zich pas te roeren als de uitzonderingen op de regel van de zondagssluiting aan de orde zijn. De apotheek, het café, de benzinepomp, de fietsenmaker, de banketbakker en meer van dergelijke zaken in uiterst urgente artikelen mogen de consument volgens het ontwerp ook 's zondags uit de brand helpen, terwijl voorts de gemeenten neringdoenden bij bijzondere gelegenheden ontheffing kunnen verlenen van de door de wet voor zon- en werkdagen vastgestelde sluitingsregeling.

De vrije zondag, de dag des Heren. Hoeveel kabinetten liepen al niet om deze hete bri] heen voordat ten slotte Ruys III "[dit] verboden terrein van beginselvragen" durft betreden ?!

Wat een schande dat het kabinet zich verlaagt tot flagrante schennis van de zondagsheiliging en ter wille van de commercie de hand licht met Gods wil en de ware Calvinistische religie. Dit ontwerp is weer een staaltie van puur rooms pragmatisme, banvloekt de SGP-fractie.

En zo tiert deze theocratische kamerclub er maar op los, alsof het niet de christelijk-historische minister Slotemaker was die twee jaar geleden zijn hele zlel en zaligheid in dat wetsvoorstel legde ...

Behalve Kersten c.s. zitten er ook nog andere dominees in "s lands vergaderzaal. De antirevolutionair dr. $\mathrm{H}$. Visscher en de "solitaire" C.A. Lingbeek, bijvoorbeeld. De een is gereformeerd-hervormd, de ander hervormd-gereformeerd, maar - voor het gemak van de buitenstaander -: beiden zijn lidmaat van de Nederlandse Hervormde Kerk. De zondag, 
betoogt Visscher, is de dag van religieuze bezinning, niet van lichtzinnig vermaak. Aan een doodenkele inbreuk op de zondagsrust van een minderheid valt evenwel niet te ontkomen, wil men de gelovige met zolets hinderlijks als een barstende hoofdpijn of een kapotte fietsband de gang naar de kerk niet beletten. Zó streng is de geloofsleer van Calvijn nu ook weer niet, werpt Lingbeek tegen. Zeker, aan de verheerlijking van God is alles dienstbaar, maar zelfs de ascetische kerkhervormer nam "s zondags de tijd om zich met balspel te vermaken.

De fracties van de SDAP, de VDB en de RKSP kunnen zich goed vinden in het wetsontwerp, dat orde op (middenstands-)zaken stelt, de zondagsrust verzekert en - in de visie van de staatspartij - bovendlen bijdraagt tot een gepaste viering van de Zondag.

Zonder de bijval van orthodox-rechts, maar wèl met de brede steun van de grootste oppositiefracties in beide kamers, voltooit minister Verschuur in 1930 de winkelsluitingswet (Staatsblad nr. 460), die op 1 mel 1932 in werking treedt.

\section{* Etherrantsoen}

Terwijl Verschuur nog wat sleutelt aan een wet op de arbeidsbemiddeling en aan een herziening van de drankwet en de woningwet, komt waterstaatsminister Reymer, voormalig burgemeester van de Radiostad, medio mei 1930 met zijn radiozendtijdbesluit op de proppen.

In etherland opereren op dat moment vijf omroepverenigingen. De organisatie die op initiatief van radiopionier Willem Vogt in 1923 voor het eerst begon uit te zenden, was de Hilversumsche Draadlooze Omroep, die na enkele tussentoestanden in 1928 de AVRO ging heten. Vervolgens ontdekten ook vier andere - eveneens nu nog alleen onder de beginletters van hun naam bekende - verenigingen het nieuwe massamedium: de NCRV (1924), de KRO en de VARA (1925) en de VPRO (1926). De AVRO zond uit op Hilversum, de NCRV en de KRO maakten samen gebruik van een eigen zender in Huizen, terwill de VARA en de VPRO op belde zenders de "daluren" mochten vullen.

De verdeling van de zendtijd was bepaald niet naar leders genoegen. En ofschoon het intermezzokabinet-De Geer er nogal huiverig voor was om beginselvraagstukken aan te snijden, besloot het de omroepkwestie in 1927 voor te leggen aan een staatscommissie. Welke kant dat op zou gaan, bleef even in nevelen gehuld. Want in de persoon van Ruys kreeg de commissie een voorzitter die destijds in het eerste nummer van de KROgids van 1 mel 1925 schreef: "Ter verspreiding van de waarheid worde geen middel verwaarloosd..." 9 
Een cryptisch zinnetje, maar het vertaalde zich naar alle waarschijnlijkkeid in het warme pleidooi van de staatscommissie om de radiozendtijd, evenredig aan hun ledental over de bestaande omroepverenigingen te verdelen, zonder dat er voor een nationale omroep ruimte overbleef.

In het ontwerp tot aanvulling van de telegraaf- en telefoonwet bond de regering het gebruik van een zender aan de toestemming van de minister van waterstaat, maar trof geen regeling voor de verdeling van de zendtijd en liet alzo de weg naar een nationale omroep geheel open. Evenwel leidde een amendement van de antirevolutionair Van Dijk alsnog tot een zendtijdverdeling naar billijkheld, en voegde het ook een adviesorgaan, de radioraad, aan de wet toe.

De wetswijziging is inmiddels al twee jaar een feit als minister Reymer in maart 1930 het advies van de radioraad ontvangt. Een omroepbestel met twee keer per week een algemeen programma, verder een paar uur zendtijd voor de "kleintjes", zoals de VPRO, en het leeuwendeel voor de vier grote zuilen. Met dit advies kan Reymer redelijk uit de voeten, alleen springt de AVRO er wat te gunstig uit. En voor alle zekerheid vraagt de bewindsman tòch nog even in het Torentje en de ministerraad naar de bekende weg, voordat hil op 15 mei 1930 in afwijking van het advies van de radioraad besluit de grote vier evenvee/ zendtijd te geven.

Het radiozendtijdbesluit veroorzaakt een golf van protest bij de AVRO. Als algemene, onafhankelijke radio-omroep die het breedst denkbare culturele en sociale terrein zegt te bestrijken, kan deze vereniging zich onmogelijk schilken in de haar opgedrongen status van "zuil", die in de voorstelling van de minister enkel de liberale, vrijzinnige geestesstroming zou vertegenwoordigen. In tegenstelling tot de andere omroepverenigingen, die elk alleen maar hun eigen levensbeschouwelijke of politieke deuntje laten horen, zou de enige algemene omroeporganisatie dan ook de hele week in de lucht moeten zijn, meent de AVRO.

De liberaal mr. G.A. Boon kan met de AVRO meevoelen. Als een nationale omroep in een godsdienstig en politiek zo verdeeld land als Nederland kennelijk een utopie is, laat dàn de AVRO tenminste vanuit Hilversum een algemeen programma uitzenden, terwijl men daarnaast voor de bijzondere programma's van de andere omroepen op de zender Huizen kan afstemmen. Met een motie, meeondertekend door de vrijzinnig-democraat Oud, nodigt de liberaal de minister uit een "zodanige regeling te treffen, dat gedurende de hele week in Nederland een algemeen programma hoorbaar zal zlijn, onder deugdelijke contrôle op de samenstelling van dat programma." 10 Maar een gelegenheidscoalitie van groot rechts en dito links doet die poging tot "ontzuiling" van de AVRO stranden.

Een verticaal omroepbestel, gekoppeld aan horizontale programmering, 
dát zijn de zegeningen van het radiozendtijdbesluit waar Nederland voortaan van zal lusten.

\section{* De gemeentewet herzien}

Je weet natuurlijk wel wie het zegt. Maar als je die-hard Lingbeek de algehele herziening van de gemeentewet in zijn stemverklaring hoort uitmaken voor "restauratie van middeleeuwse toestanden" 1 ", bekruipt je toch even het gevoel: die eerwaarde is ouderwets op ketterjacht. Oppenheim, de magistrale herschepper van Thorbeckes gemeentewet, is inmiddels wijlen, en als verdediger van diens meesterwerk moet Ruys het dan maar ontgelden.

Ketterij nummer een is het regeringsvoorstel om geestelijken niet langer uit te sluiten van het raadslidmaatschap. Lingbeek is daar fel tegen omdat hil lekenraadsleden wil behoeden voor sterke morele pressie - undue influence - van de zielenherders. Van de roomse met name, want hervormde pastores mogen van hun kerk geen lid van de gemeenteraad zijn. Zijn amendement tot handhaving van de uitsluiting haalt geen meerderheld, maar 22 stemmen vóór duiden erop dat de hervormd-gereformeerde staatspartij niet alléén staat in haar verzet tegen de openstelling van gemeentelijke functies voor geestelijken èn - ketterij nummer twee - voor vrouwen, niet te vergeten.

Dat de regering de functies van burgemeester, secretaris, ontvanger en ambtenaar van de burgerlijke stand wil openen voor vrouwen is een van de belangrijkste wijzigingsvoorstellen die het ontwerp inhoudt. Als echter uit het voorlopige verslag van het voorbereidende onderzoek blijkt dat "verscheidene" Tweede-Kamerleden zich niet met dat voorstel kunnen verenigen, trekt het kabinet de conclusie dat het niet kan rekenen op voldoende steun van de drie bevriende kamerfracties, en neemt Ruys het voorstel terug.

Ja, geef daar maar eens een draal aan in een kamer met zeven vrouwen, van wie er een bij Nolens en een ander bij Schokking in de fractie zit. Handhaven van de openbare orde en de orde in de vergadering van de raad is beslist geen sinecure, en ook taken als toezicht houden op herbergen en openbare vermakelijkheden vragen van de burgemeester een zekere mate van kordaatheid en tact. Maar of een en ander nu werkellijk "... eisen stelt, waaraan in den regel de vrouw niet voldoet ...", zoals Ruys na politieke heroverweging beweert ?! ${ }^{12}$

Bij amendement voert Johanna Westerman (liberaal) het teruggenomen regeringsvoorstel weer op. En met de steun van haar vrouwelijke collega's, de linkerzijde en Nolens met een handvol getrouwen krijgen vrouwen zo 
toch toegang tot de vier gemeentelijke functies in kwestie.

De verantwoordingsplicht van burgemeester en wethouders. Voor somm gen zit er bljjkbaar te veel ruis in artikel 183 (nadien artikel 216 oud), ste de memorie van toelichting vast. Vandaar dat "... de nieuwe voorgesteld redactie nog verduidelijkt hetgeen reeds in het geldend artikel ligt, name lijk dat de verantwoordelijkheid [van B\&W tegenover de raad] zich allee uitstrekt over het bestuur van de huishouding der gemeente [de autono me aangelegenheden] en niet ook over de medewerking van burgemees ter en wethouders aan de uitvoering van regelingen van hoger gezag [t ken in medebewind]. Bovendien is de verantwoordelijkheid beperkt to het door [het college] gevoerd bestuur ..." 13

Een amendement-Marchant, dat de raad het recht wil geven B\&W oc voor bestuursdaden in medebewind op het matje te roepen, krijgt allee de steun van de fracties van de VDB en de SDAP.

Hetzelfde lot treft ook een amendement-Van den Bergh. Het is voor dez soclaal-democraat onacceptabel dat de raad er niets mee te maken zo hebben hoe de burgemeester zilin gemeentelijke politietaak vervult. Net a over het vorige amendement verklaart Ruys dat de raad geen interpellatie recht toekomt als het aangelegenheden betreft die niet tot de bevoegc heden van dit orgaan behoren.

Geen steun van de kamermeerderheid, maar het is wel staatsrechtgoero C.W. van der Pot die zijn latere collega-hoogleraar G. van den Bergh bi valt. Dat de burgemeester de raad thans geheel buiten de gemeentelijk politiezaken kan houden is politiek ongewenst en doorbreekt bovendie het [tot 1931 geldende] systeem van de gemeentewet (de toenmalig artikelen 134 en 183), dat voor alle aan het college of de burgemeeste opgedragen autonome bestuurstaken uitging van de verantwoordings plicht aan de raad - het hoogste orgaan van de gemeente. ${ }^{14}$

Moet een argeloos mens nu uit dat betoog afleiden dat politiek $\mathrm{e}$ staatsrechtswetenschap hand in hand gaan ? jazeker, zegt Van der Po want de vraag wat recht verdient te zijn "... kan niet beantwoord worde bulten den invloed van eigen levensbeschouwing en dus van politiek ir zicht." is

Ondanks al die rechtse en linkse bedenkingen tegen het ontwerp-gemeer tewet geeft de Tweede Kamer in het eerste zittingsjaar ook aan dit belang rijke onderdeel van het regeerprogram haar fiat. De tegenstemmen - na dien ook in de Senaat - komen voornamelijk uit de hoek van de protes tantse fracties, maar zijn niet talrijk genoeg om Ruys te verhinderen d herzlene gemeentewet op 31 januari 1931 in het Staatsblad (nr. 41) t 
plaatsen.

\subsection{De kentering}

1930. John Maynard Keynes blikt in de toekomst. We staan op de drempel van een nieuwe tijd, het technologische tijdperk, waarin de machine de mens het werk uit handen neemt. "Dat betekent", aldus de beroemde Engelse econoom, "dat de mensheid in the long run haar economische problemen oplost ... Zal dat een voordeel zijn ? Er is geen land en geen volk dat zonder angst vooruit kan kijken naar het tijdperk van vrije tijd en overvloed. Het is voor de gewone mens, zonder speciale talenten om zichzelf bezig te houden, een angstwekkend probleem ..." ${ }^{16}$

Geen grote economische zorgen dus voor de dag van overmorgen ! Dankzij de werking van de vrije-markteconomie gaan onze kleinkinderen een moole toekomst - met hooguit een enkel luxeprobleem - tegemoet. Dat hun grootouders momenteel massaal zonder werk zitten, is, volgens Keynes, dan ook slechts een tijdelijke hapering van het marktmechanisme, die met stimuleringsmaatregelen van de overheid in the short run te verhelpen is.

Edoch, "De Labour-regering van MacDonald", schrijft Churchill, "was volkomen buiten staat de problemen, waarvoor zil zich gesteld zag, het hoofd te bieden." ${ }^{17}$ Zou het kabinet-Ruys het er beter afbrengen en wél weten wat conjuctuurbeleid verlangt ?

\section{* Tasten en zoeken}

Is de troonrede van 1929 nog vrij optimistisch over de economische situatie van ons land, kort daarop openbaren zich grote problemen in de landbouw. Een hoog binnenlands aanbod, samen met een sterk concurrerende aanvoer uit het buitenland en daarbij nog een stagnerende export, bederft de markt voor diverse agrarische producten. De verkoopprijzen zakken tot onder de kostprijzen. En als gevolg van deze verliesgevende productie komen legio boeren in de rode cijfers terecht.

In maart 1930 stelt het kabinet een commissie in om zich te laten adviseren over maatregelen die de landbouw uit de nood moeten helpen. Op advies van deze commissie onder voorzitterschap van het TweedeKamerlid dr. H.). Lovink ( $\mathrm{CHU}$ ) is enige maanden later de eerste protectionistische maatregel een feit als een hoog invoerrecht op "witte" suiker de inheemse suikerbiet voor subiete ondergang moet behoeden.

Het vrijhandelsstelsel brokkelt nog verder af als in het najaar van 1930 een 
ontwerp-tarwewet bij de kamer in behandeling komt. Op advies van de commissie-Lovink beoogt het ontwerp de meelproducent te verplichter een zeker - door de regering nader te bepalen - percentage inlandse tarw in zijn product te vermalen.

De liberalen en de vrijzinnig-democraten hebben grote moeite met di "wangedrocht", dat de landbouw geen enkel profijt en de andere bedrijfs takken grote schade berokkent. Begin je er eenmaal mee de tarwebouw ir Nederland kunstmatig in leven te houden, waarschuwen de "vrijhande laars", dan is het eind zoek! Dat is waar, want na de uitvaardiging van he maalgebod kloppen ook de producenten van fabrieksaardappelen, aard appelmeel, rogge, vlas, riet, etc. al spoedig om steun aan bi] de overheid.

Net op een moment dat de werkgelegenheid sterk terugloopt, breng minister Verschuur met zijn arbeidsbemiddelingswet van 1930 wat struc tuur in de banenmarkt. Nadat particuliere bureaus zich in de laatste de cennia van de negentiende eeuw waren gaan toeleggen op arbeidsbemid deling, kwamen diverse gemeenten in het begin van de twintigste eeum tot het inzicht dat er op dit gebied ook een taak voor de overheid wa weggelegd. Er kwamen gemeentelijke arbeldsbeurzen van de grond, die ir een volgende fase vraag- en aanbodgegevens onderling gingen uitwisse len. Toen echter bleek dat deze (inter-)gemeentelijke aanpak als wapen ir de strijd tegen de werkloosheid tekortschoot, rees de behoefte aan enige centrale sturing.

Volgens de wet van 1930 krijgen districtsbeurzen de taak de arbeids. bemiddeling van de gemeentelijke beurzen te coördineren, terwijl eer nader in te stellen rijksorgaan de hele operatie vanuit één centraal pun moet gaan leiden en zich straks ook moet bezighouden met bemiddeling van arbeidskrachten die over de grens werk zoeken. ${ }^{18}$

Laat de regulering van de arbeidsmarkt toch rustig over aan particulier initlatlef, kritiseren Colijn en de liberaal ir. C.L. van der Bilt de minister. Maal afgezien van de fractles van de antirevolutionairen en de liberalen in beide kamers ziljn alle partijen met Verschuur van mening dat de overheid he onderdeel arbeidsbemiddeling van het bredere vraagstuk van de werkloos. heidsbestrijding niet op zijn beloop mag laten.

Tasten en zoeken. Ook met fiscale maatregelen probeert het kabinet de economie aan de gang te houden.

Sinds 1914 bestat er een rijkscrisisfonds dat de aflossing waarborgt var de staatsleningen waarmee indertild de gevolgen van de oorlogstoestanc zijn gefinancierd. Het fonds put zijn inkomsten uit jaarlijkse heffingen, die al een tijdlang meer opbrengen dan voor de aflossing van de leninger 
nodig is. Aan het overschot van het fonds wil het kabinet thans een nuttige bestemming geven.

In zijn begroting voor 1930 kondigt De Geer een verlaging van de crisisfondsheffingen aan, onder afschaffing van de opcenten op de sulkeraccijns en vermindering van de verdedigingsbelasting.

Voor belastingverlaging is het parlement wel te porren. Die hatelijke opcenten weg is een prima idee, dat een doorsneegezin al gauw een paar dubbeltjes per week scheelt. Maar waarom dan niet óók de accljns op vlees afschaffen in plaats van de verdedigingsbelasting verlagen? Het mes snijdt dan immers aan twee kanten, heeft zowel voor de consument als voor de vleeshandel voordelen, argumenteert de Tweede Kamer.

De Geer houdt echter voet bij stuk. Het kamervoorstel komt ten laste van de gewone dienst en de minister wil nu eenmaal alleen het overvolle crisisfonds aanspreken ... Het reservepotje, hoe angstwekkend leeg zou het over twee jaar zijn !

Het eerste regeringsjaar zit erop. De hausse van de laatste jaren is voorbij. De economie bevindt zich in een neerwaartse spiraal. Of deze negatieve ontwikkeling een terugslag is die gewoon van tijd tot tijd voorkomt, of een voorteken is van een crisis, niemand weet het.

Zeker is wel dat de landbouw het zwaar te verduren heeft, maar heeft dat zorgenkindje daar niet vaker last van? Nu echter ook de veeteelt en de scheepvaart beginnen te klagen en het werkloosheidscijfer inmiddels de honderdduizend is gepasseerd, "vormen de wolken toekomstland" ${ }^{19}$, zoals het kabinet met luchtige dichterlijkheid moet erkennen.

\subsection{Het malaisejaar 1931}

Er hangen weliswaar wolken boven het budget, maar voorlopig geeft de toestand van 's Rijks financiën nog geen aanleiding om bijzondere maatregelen te treffen. In de verwachting dat de inkomsten in 1931 op pell blilven, is een kleine verhoging van enkele accijnzen voldoende om het begrotingstekort van $f 6$ miljoen op te vangen en enige reserve voor nleuwe steunaanvragen aan te leggen. Als de depressie maar niet te hard toeslaat, hoeven we ons geen overmatige zorgen voor 1931 te maken, schrifft de miljoenennota geruststellend.

De eerste die bij De Geer aan de bel trekt, is collega Verschuur. Een subsidie hier, een premie daar, het zijn allemaal lapmiddelen die niets weg hebben van effectief economisch beleid. De overheid moet er in tijden van recessie alles aan doen om de inzakkende economie nleuwe impulsen te 
geven. Economische voorlichting is daarbil onontbeerlijk. Voor Verschuur spreekt het dan ook vanzelf dat de minister van financiën bijpast als de minister van arbeid een interdepartementale economische voorlichtingsdienst wil opzetten. Maar De Geer weigert over de brug te komen, waarop Verschuur er in een brandbrief aan Ruys op 30 oktober 1930 een portefeuillekwestie van maakt, en zijn zin krijgt. Een ministerscrisis om de bestrijding van de economische crisis: dát ontbrak er nog maar aan!

\section{* Pachtrecht in crisistijd}

Tegen het eind van de negentiende eeuw kwam duidelijk naar voren dat de in het Burgerlijk Wetboek van 1838 getroffen regeling van de verhouding tussen de grondeigenaar en de pachter veel te wensen overliet. Het zou echter eerst oorlog moeten worden, schrijft prof. mr. A. Pitlo, voordat "... de illusle, dat de economische vrijheid de economische billijkheld met zich mee zou brengen, niet langer te handhaven was en de sociale gedachte haar zegetocht begon. Maar machtig waren de elementen die van een soclale wetgeving voor de pachtverhouding ernstig persoonlijk nadeel vreesden ..." 20

Een staatscommissie onder voorzitterschap van prof. mr. P. A. Diepenhorst kreeg in 1919 van de regering de opdracht te bezien of de bestaande wettelijke regeling van de pacht wijziging behoefde. In 1923 deed de commissie een tweetal wetsvoorstellen: het ene strekte tot een nieuwe regeling van de pacht en het andere tot instelling van pachtcommissies.

Gezamenlijk dienden de ministers van landbouw en justitie in het kabinetDe Geer beide wetsvoorstellen zes jaar later bij de Tweede Kamer in. De voorgestelde regeling hield een redelijke verbetering van de positie van de pachter in. Zo boden hem de rechten van napacht (continuatierecht) en pachtvermindering in geval van misoogsten e.d. (remissierecht) meer bestaanszekerheld, terwijl hil bij het eind van de pacht recht op vergoeding voor aangebrachte verbeteringen (melioratierecht) tegen de verpachter kon laten gelden.

Het staat er slecht voor met de landbouw als in oktober 1930 de openbare behandeling van het ontwerp-pachtwet in de Tweede Kamer van start gaat. Ruys en Donner komen er bij de verdediging van het ontwerp al gauw achter dat de bepalingen ter bescherming van de pachter in de ogen van de fracties van de RKSP, de SDAP en de VDB onder de maat zijn.

De socialist W. van der Sluis en de katholiek A.N. Fleskens richten hun geschut op het remissierecht. Laat de pachtprijs schommelen naar gelang van goede of slechte tijden, amendeert de een, of laat de rechter er zich 
eens in de drie jaar mee bemoeien, varieert de ander. De bedrijfsresultaten kunnen het ene jaar minder zijn dan het andere jaar, repliceert Ruys, maar dat hoort - behoudens in geval van misoogsten en andere buitengewone omstandigheden - tot het normale ondernemersrisico. Met grote meerderheid stemt de kamer vervolgens beide wijzigingsvoorstellen af. Ook het melioratierecht gaat Van der Sluis niet ver genoeg. De pachter zou recht op vergoeding voor alle door hem aangebrachte verbeteringen moeten hebben, zonder dat het de partijen vrijstaat - zoals het ontwerp toelaat - daar bij contract van af te wijken. Maar dan dring je de verpachter mogelijk iets op waar hil geen belang bij heeft, werpt Donner tegen. En de meerderheid van de kamer denkt daar al niet anders over.

De kritiek barst pas echt los als het continuatierecht aan de orde is. Van recht op napacht is volgens het ontwerp alleen sprake indien de rechter verlenging op de oude voorwaarden redelijk acht.

Op de oude voorwaarden, in een tijd die niet stilstaat: dat is óók een manier om aan te geven dat je weinig met napacht ophebt. En dan te bedenken dat het "grootgrondbezit" in het oosten van het land in een indertijd door de staatscommissie-Diepenhorst ingestelde enquête te kennen gaf dat een "goed pachter" onrecht wordt aangedaan als hij na afloop van de contractuele termijn zonder meer het veld moet ruimen. "Zij [de grondmagnaten』 waren bekend met het agrarische leven en het was juist de stedelijke verpachter die, als gevolg van zijn volslagen onkunde ten aanzien van het reilen en zeilen der agrarische exploitatle, aan zijn pachter een aanspraak op continuatie ontzegde ..." ${ }^{2 !}$, betoogt pachtdeskundige jhr. mr. Carel van Nispen tot Sevenaer met een steelse speldenprik in het (rand-)stedelijke pachtbeleid van het kabinet van zljin schoonvader.

Wat het kabinet met napacht van plan is, past niet in het straatje van de fracties van de katholieken, de sociaal- en de vrijzinnig-democraten. Laat men de rechter oordelen over verlenging van de pacht, dan moet hij ook de pachtprijs kunnen aanpassen, brengt Fleskens in een amendement tot uiting. Van der Sluis doet daar nog een schep bovenop: anders dan in het ontwerp, dat pachtverlenging aan een maximumtermijn bindt, moet de rechter de vrijheid hebben om napacht voor onbepaalde tijd toe te staan. Voor de vrijzinnig-democraat F.E.H. Ebels is verplichte napacht een onding, dat verpachters en pachters tegen elkaar opzet. Hij zoekt de oplossing in een regeling die de pachter recht op schadevergoeding geeft als de verpachter hem na afloop van de contractuele termijn zonder dringende reden afdankt.

Nu was het continuatierecht al eerder de grote boosdoener, dle de indiening van het ontwerp-pachtwet niet voor nlets zo lang ophield. Donner kan zich dat als mede-indiener van het wetsontwerp nog scherp herinne- 
ren. En hij weet ook maar al te goed dat twee bevriende kamerfractie nogal allergisch zijn voor staatsinmenging in pachtzaken. De minister aai zelt dan ook niet de amendementen te ontraden. Twee amendemente sneuvelen, maar het amendement-Fleskens haalt het met vereend rooms-rode krachten wèl.

Het zijn juist de drie Tweede-Kamerfracties met de meeste kritiek op he ontwerp-pachtwet die het bil de eindstemming in november 1930 eer ruime meerderheid bezorgen. De liberalen en het gros van de leden var de protestantse fracties stemmen tegen. Hun grote grief is het continua. tlerechit, dat door toedoen van Fleskens c.s. de contracturijheid wel ers sterk aan banden legt.

De "zegetocht van de sociale gedachte" zet zich in beweging, maar verandert binnen vifftien maanden in een complete aftocht na de confrontatie met de Senaat.

ledereen spitst zijn oren als Diepenhorst aan het woord is. Het ontwerp het is tenslotte goeddeels zijn werk - bevat veel goeds, prijst de antirevolutionaire senator. Maar dat kan hij niet zeggen van het voorgestelde continuatierecht, dat het eigendomsrecht dermate aantast als alleen bij dringende noodzaak gerechtvaardigd kan zijn. Is een zodanig napachtrecht in de huidige situatie voor Diepenhorst niet aanvaardbaar, toch zou zijn fractie in het belang van een gezonde pachtverhouding wel kunnen meegaan met de oplossing die Ebels destijds in de Tweede Kamer aandroeg.

Ruys en Donner ruiken hun kans. Een keus voor continuatierecht of voor recht op schadevergoeding bij onredelijke pachtopzegging: dát is toch om het even, werpen zij Diepenhorst tegen. Beide opties maken immers inbreuk op het eigendomsrecht, en waarom zou men dan de pachtwet in dit stadium louter en alleen om een kwestie van vormgeving afwijzen?!

De logica achter de regeringstafel werkt niet. De antirevolutionairen, de liberalen en - anders dan in de Tweede Kamer - alle christelijk-historischen en zes katholieken houden onoverkomelijke bezwaren tegen het continuatierecht, waarop de Eerste Kamer de pachtwet in februari 1932 met 25 tegen 21 stemmen verwerpt.

De houding van de Eerste Kamer tegenover de pachtwet, verzucht senator Kranenburg, is het zoveelste bewilis dat haar leden enige graden conservatiever zijn dan hun partijgenoten aan de overzijde van het Binnenhof. ${ }^{22}$ Zou het elgenaardige getrapte kiesstelsel het opstapje naar de Senaat soms een beetje apart maken?

Na een lange omzwerving is de pachtwet weer terug bij af. Wat nu ? Voelt 
het kabinet zich geroepen de pachters in crisistijd de helpende hand toe te steken, of is de Tweede Kamer het aan haar politieke primaat verplicht het veto van haar zustercollege nlet zomaar te pilken?

De Tweede Kamer blaakte de afgelopen vifftien maanden in elk geval van strijdlust. En wellicht springt zil well in één moeite voor de pachters in de bres.

\section{* Smerige, ellendige troep}

We keren terug naar november 1930. De pachtwet is nauwelijks door naar de Eerste Kamer, of de Tweede Kamer zit al weer druk te discussiëren over minister Deckers' vlootplan met hieraan annexe vraagstukken van landsverdediging en mobilisatie.

De verwerping van de vlootwet in $1923^{\prime \prime . . . ~ w o r d t ~ d o o r ~ h e t ~ K a b i n e t ~ i n ~ d e ~}$ gegeven omstandigheden als felt aanvaard ... Middelerwill zal de Regeering de verzorging van de maritieme verdediging opnleuw ter hand nemen ...", zo klonk het in de regeringsverklaring die Ruys na afloop van de kabinetscrisis op 15 januari 1924 in de Tweede Kamer aflegde.

Het is middelerwijl 1927 als het kabinet-De Geer bil koninklikk besluit een maritiem defensieplan voor Nederlands-Indië vaststelt. $\mathrm{Nu}$, drie jaar later, komt defensieminister Deckers met het voorstel, aan dat met "minimumplan" betitelde defensieplan een reserve van $50 \%$ - te weten: kruiser, 4 torpedobootjagers en 6 onderzeeboten - toe te voegen, en voor de geleidelike uitvoering van het totaalplan - als te verwachten prompt het "halve minimumplan" genoemd - jaarlijks begrotingsgelden ut te trekken.

In hun verzet tegen het vlootplan leggen de ontwapenaars - soclalisten, communisten en vrijzinnig-democraten - het in beide kamers af tegen de rest, die de minister aan een ruime meerderheld helpt. Maar vóór het zover is, moet de socialistische fractieleider Albarda in de Tweede Kamer eerst aan een scherp verhoor geloven.

Wat bedoelde Albarda, toen hij onlangs in zijn toespraak tot het congres van de SDAP verklaarde "... dat, wanneer de regeringen de mlsclaad van den oorlog zouden ontketenen, daartegen elk doelmatlg middel geoorloofd is, ook al valt het ver buiten het wettelijk geoorloofde ..." ? ${ }^{24}$

De woorden zitten hem vóór in de mond. De voormalige schildersgezel, ooit ijverig klussend voor een latere liberale premier, toevallig ook nog De Meester geheten, hoe graag zou de socialistische afgevaardigde Johan Schaper zijn hart nog eens ongezouten luchten, hardop herhalen waarvoor de kamervoorzitter hem in 1910 tot de orde riep: "Smerige, ellendige troep! Dompers benn' jullie." ${ }^{25}$ Een Groninger dus, en inmiddels gedoemd 
tot niet-onparlementair taalgebruik.

Maar Schaper bijt op zijn tong, en Albarda aanvankelijk ook. Van Dijk en Tilanus wachten echter ongeduldig op antwoord. En de minister wil er ook hoognodig het zijne van weten. Albarda schikt dan wat in. Hij wil wel kwijt dat de SDAP een politiek afwijst die naar oorlog drijft of oorlogsgevaar oproept. In dergelijke gevallen zal zijn partij clan ook een mobilisatiebevel saboteren. Ziln congresuitspraak richt zich tegen oorlogszuchtige regeringen, en een goed verstaander denkt dan toch niet direct aan ons landsbestuur ... Nee hoor, stel je voor, een toespraak tot Nederlandse partijgenoten op een tegen het vlootplan gericht demonstratief congres !

Hebben Deckers, Van Dijk en Tilanus er nog steeds geen flauw idee van of de SDAP bereid is een mobilisatiebevel op te volgen, voor de communist L. de Visser, een in 1909 geroyeerd SDAP-er, is het volkomen duidelijk dat Albarda tijdens het SDAP-congres de macho wilde uithangen en nu niet de moed heeft om die stoere taal te herhalen. Als het erop aankomt capituleren sociaal-democraten voor het militarisme en het imperialisme: "Daar zitten zilj nu, de politieke dominees zonder Onzen Lieven Heer" ${ }^{26}$, hoont De Visser zijn voormalige strijdmakkers.

Kamervoorzitter Van Schaik roept De Visser tot de orde, maar deze is niet meer te stuiten. Als een razende gaat hij vervolgens tekeer tegen de heksenjacht op de Sovjet-Unie: "... van den Paus af tot aan den rabbi toe..." 27 En prompt waarschuwt Van Schaik hem voor de tweede keer.

Meende de Tweede Kamer tot 1918 dat haar voorzitter leden die zich beledigende uitlatingen veroorloofden of de orde verstoorden, in de regel wel weer met een zacht vermaan in het gareel kon brengen, van die mening was de kamer snel genezen toen in dat jaar communisten hun intree op het Binnenhof deden.

Krachtens het in 1919 aangescherpte reglement van orde kan de voorzitter - voortaan zonder de toestemming van de kamer - een kamerlid dat zich misdraagt het woord over het desbetreffende agendapunt ontnemen. Tevens biedt het reglement sindsdien de mogelijkheid om een kamerlid uit te sluiten van de verdere bijwoning van de vergadering, waarna dat lid meteen het kamergebouw moet verlaten.

De Visser, minder inschikkelijk dan Schaper destijds, lapt ook de tweede waarschuwing aan zijn laars, blijft tegen de klippen op schelden en tieren, en maakt daarna successievelijk kennis met de twee nieuwe tuchtmaatregelen van 1919. Rijksveldwachters, rechercheurs en enkele inspecteurs van politle moeten er aan te pas komen om hem uit het kamergebouw te verwijderen.

Lou de Visser, een man van verzet, zijn leven lang, tot aan zijn gewelddadige dood in oorlogsjaar 1945. 


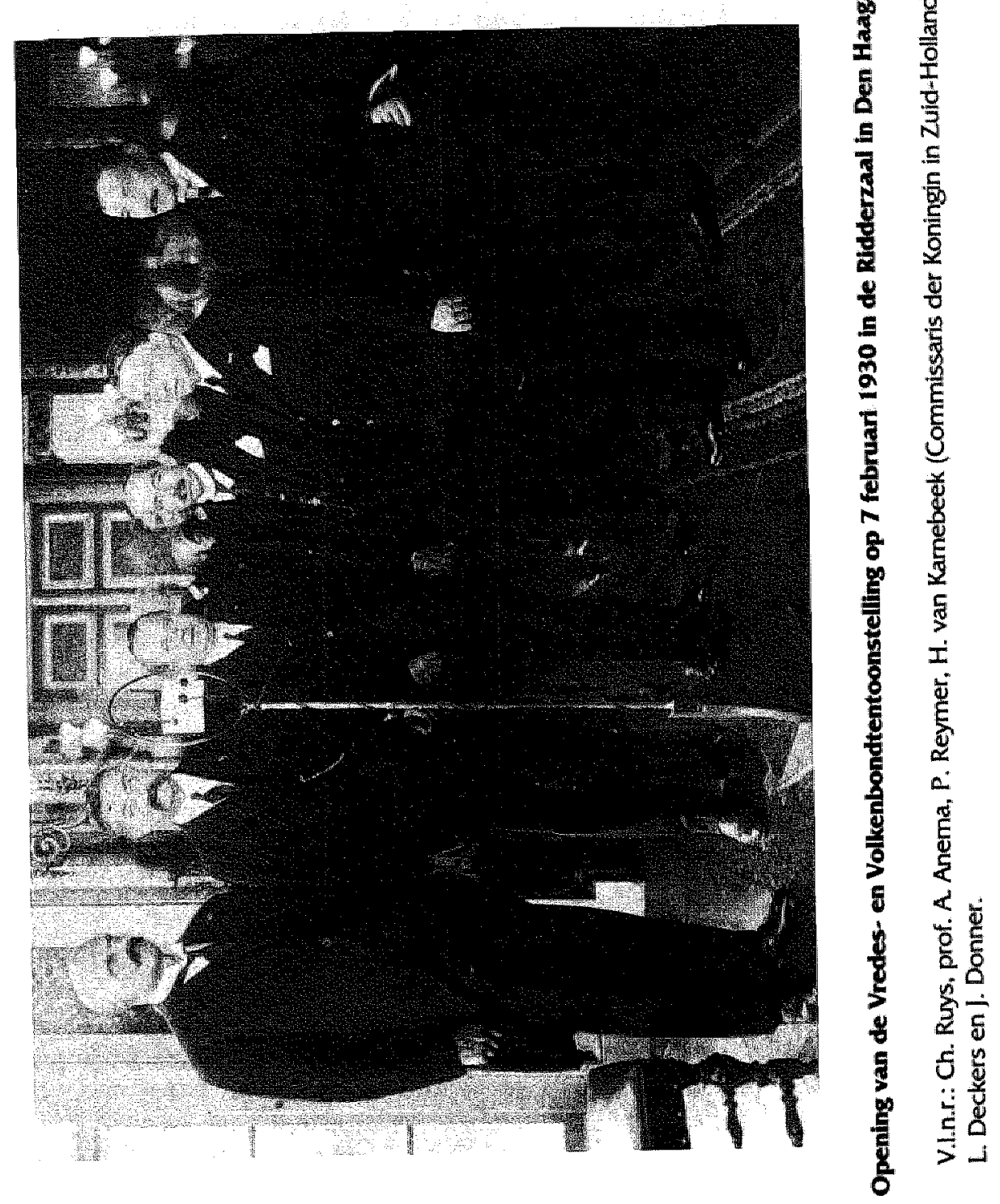


Kort na de stemming over het vlootplan komt Marchant bij de algemene beschouwingen over de rijksbegroting voor 1931 op het mobilisatievraagstuk terug.

Albarda heeft volkomen gelijk, verklaart Marchant, dat volken zich met alle middelen mogen verzetten tegen het gezag dat hen in enkele minuten in de afgrond kan storten. En bovendien, waar haalt de minister van defensie het recht vandaan om Albarda in de kamer een verhoor af te nemen over diens uitspraken tijdens het SDAP-congres ? De regering is er om verantwoording aan de kamer af te leggen, niet omgekeerd!

Riekt dat laatste naar de leer van de volkssoevereiniteit, die de regering ziet als een stelletje agenten in dienst van de volksvertegenwoordiging. Heemskerk daarentegen vindt het volkomen normaal dat het kabinet moet weten wat het van de SDAP kan verwachten als het gaat om belangen van staatsvefligheid.

En zo denkt Ruys er ook over. Hoe stelt de SDAP zich op als de regering ter verdediging van het land tot mobilisatie moet besluiten, vraagt hij Albarda. Als bekend, is mijn partij, aldus de sociaal-democraat, tegen gewapende landsverdediging en derhalve ook tegen een mobilisatiebevel. Maar - ingevolge een resolutie van het SDAP-congres van 1928 - houdt de partij “... rekening met de mogelijkheid, dat onder bepaalde omstandigheden een mobilisatle van beperkten omvang, op den voet van een veiligheidswacht, ook door ons onvermijdelijk kan worden geacht ter bescherming tegen gevaren, waaraan een oorlog buiten onze grenzen de bevolking van ons land blootstelt ... [en] is dus van oordeel, dat niet van te voren de houding der partil en die harer vertegenwoordigers voor elk geval van mobilisatie kan worden vastgesteld ..." 28

Nou, dan weten wil het wel, smaalt pestkop De Vlsser. En ook Ruys: "De regering zal uit dit alles bij het door haar te voeren beleid de gewenste conclusies trekken ..." ${ }^{29}$, is voor dit moment - 12 november 1930 - voldoende geïnformeerd.

\section{* Aanpassing aan de verminderde welvaart}

Met de financiën valt het allemaal nog best mee als blijkt dat de winst- en verliesrekening over 1930 sluit met een voordelig saldo van $f 27$ miljoen. Tegelijkertijd is de stijging van het aantal werklozen tot 140.000 - in een jaar tijd van $2 \%$ naar $5 \%$ van de beroepsbevolking - een indicator dat er lets aan de hand is met de economie.

Het beroep op de steunkassen voor werklozen neemt almaar toe. Kunnen de kassen met de ruim $f \| 1$ miljoen waarover zij beschikken, in 1930 nog net aan hun verplichtingen voldoen, de verdere stijging van de werk- 
loosheid in 1931 is hun al spoedig te machtig. Met ruim $f 10$ milloen extra subsidie moet de rijksoverheid dat jaar bijspringen om de steunuitkeringen te verzekeren.

Maar daar blijft het niet bij. Alleen leden van een steunkas komen bi] verlies van hun baan in aanmerking voor een tijdelijke uitkering uit dat fonds. Wie "uitgetrokken" is, of werkloos wordt en - net als de meerderheid van de beroepsbevolking - geen lid is van een steunkas, moet aankJoppen bij zijn of haar gemeente.

Ook de gemeenten hebben de kracht niet om die steeds zwaarder drukkende financiële lasten zonder hulp te dragen. Het rijk ziet zich dan ook genoodzaakt subsidies te verstrekken, die al vlug tot tientallen miljoenen guldens oplopen. Aan die doeluitkering verbindt Den Haag echter wel de voorwaarde dat de gemeenten al hun steun- en werkverschaffingsregelingen ter goedkeuring voorleggen aan de minister van binnenlandse zaken. "Aanpassing van ons gehele leven aan de verminderde welvaart", laat Ruys de gemeentebesturen in een circulaire van januarl 1931 weten, "is, zie ik het goed, onvermijdelijk. Wijs beleid zal het zijn, dat er alles op wordt gezet, herstel mogelijk te maken en niets te doen wat in verkeerde richting werkt. $U$ zult het ongetwijfeld met mij eens zijn dat het ook de werklozenzorg is, welke in deze tijden veel er toe kan bijdragen of de ontwikkeling van het maatschappelijk leven in juiste, dan wel in verkeerde richting wordt gestuurd." 30

Het heet zo gematigd: aanpassing aan de verminderde welvaart. In werkelijkheid is het echter een eufemisme voor: leren leven met een malaise die zich als een olievlek uitbreidt. De problemen stapelen zich op. Steeds meer bedrijven en bevolkingsgroepen delen in de ellende.

Het kabinet bekommert zich intussen slechts om de meest schrijnende noodgevallen. Aanvankelijk is de aandacht vrijwel uitsluitend gericht op de land- en tuinbouw, waar de sores de pan uit rijzen. Met kredieten, productiepremies, prijs- en afzetgaranties, toelagen en meer van die voor de voet verstrekte steunmaatregelen probeert het kabinet de producenten van suikerbieten, aardappels, tarwe, rogge en andere teelten die het niet kunnen bolwerken, op de been te houden. Het helpt allemaal niet, het is dweilen met de kraan open. En het gevolg is dat de werklozenzorg de ene na de andere aanvullende rijkssubsidie nodig heeft om het almaar ultdiiende legioen uitkeringtrekkers een - schamel - levensonderhoud te verschaffen.

Aanpassingspolitiek, dit is het enige antwoord dat het kabinet tot dusver op de malaise heeft. Hier en daar een brandje blussen, zien te redden wat er te redden valt èn vooral bezuinigen. Crisisbeleid dus, zonder een her- 
stelprogram voor de inzakkende economie. Een herstelprogram? Dat zou forse investeringen vergen en zo'n aderlating kan de heilige koe van het begrotingseverwicht zich niet permitteren. En daarvan afgezien, zouden de economische "snoepwinkeltjes" die Verschuur bij ziln aantreden op diverse ministeries aantrof, trouwens het benul hebben hoe zij een zinvolle bijdrage aan zo'n herstelprogram kunnen leveren?

Het is medio 1931. Er ziln inmiddels meer dan tweehonderdduizend werklozen. De tljd van voorbereiding op het begrotingsjaar 1932 gaat nu in.

\section{* Het elnd van een tijdperk}

In de stilte van 't Suideras komt Ruys midzomer 1931 net even bij van de Haagse beslommeringen als hij op 19 augustus een bericht van Th. Schaepman ontvangt, dat hem erg aangrijpt.

Dit Tweede-Kamerlid voor de staatspartij schrijft hem: "Ik weet niet of de heer Aalberse $U$ regelmatig op de hoogte houdt van den toestand van Mgr. Nolens, maar waar $U$ mil gevraagd heeft $U$ eens een en ander te melden als Ik lets hoorde doe ik [dat] bi] deze ... Volgens den heer Aalberse is de toestand 200 , dat het een kwestie is van enkele weken ... Vermoedelijk heeft hij pijnen, maar klagen doet hil nooit. Veel leest hij ook in deze dagen over het socialisme zooals zich dit in deze dagen ontwikkelt..." 31

Acht dagen later, donderdag 27 augustus, overlijdt Nolens. Met hem gaat Nederlands invloedrijkste politicus van de laatste kwarteeuw heen, een man "van groot vernuft en zeer vlugge bevatting, die in zijn geslotenheid voor vrijwel iedereen lets ondoorgrondelijks had", oordeelt historicus L.J. Rogier. ${ }^{32}$

Sinds 1897 zonder onderbreking líd van de Tweede Kamer, voerde de monseigneur vanaf 1910 de regie - naar hem goeddunkte: meestal strak, soms losjes - over de katholleke kamerclub, en was in die hoedanigheid de eminente, onbetwiste politieke leider van een partij die men moeilijk meer over het hoofd kon zien.

Allerminst een vreemdeling in het Jeruzalem van de nationale gevoeligheden, plekerde de priester-staatsman er nlet over minister, laat staan premier, te worden. ${ }^{33}$ Maar in de jaren tien en twintig was er niet één kabinet dat kon aantreden en/of voortbestaan zonder de steun van deze "(super-)minister van staat".

Karakteristlek voor Nolens is zijn maidenspeech in de Tweede Kamer: "Ik neem de zaken zooals ze nu eenmaal zijn, en bepaal mij tot bespreking 
van wat mijns inziens thans op de voorgrond staat ..." ${ }^{34}$ Nuchter, beheerst en terzake, zoals past bij lemand die politiek beschouwt als de kunst van het mogelijke.

Hoe sterk is het contrast van deze man met die andere coryfee in de politieke arena van die tijd. Ook die topper is in 1860 geboren en in 1897 voor het eerst in de Tweede Kamer gekozen. Maar dáár houdt de overeenstemming van Nolens met - de het vorige jaar overleden - Troelstra ook mee op.

De Friese politicus-dichter, met elf kameraden maakte hil zich in 1894 los - "de muiters en de makkers, die taale roole rakkers" - van de anarchistisch-revolutionaire Sociaal-Democratische Bond om het evangelle van Marx langs parlementaire - nou ja - weg te verkondigen.

De Twaalf Apostelen noemde men hen en wilden zil wezen, met Pleter Jelles in de hoofdrol van Petrus, de idealistische, impulsleve en soms wat onbedachtzame discipel, maar wèl de rots waarop in 1894 de SDAP verrees.

Elkaar 26 jaar lang in de landspolitiek zo na staan en dan van Schaepman moeten horen dat de dagen van je deelgenoot geteld zijn !

Zelfverwijt knaagt aan Ruys. Ineens neemt hij zich kwalijk dat hil niet in het reine wist te komen met ziln oude leermeester. Zeker, Nolens was egocentrisch en diens neiging om zich overal nadrukkelijk mee te bemoeien. was soms knap hinderlijk en frustrerend. Maar hij had natuurlijk zelf nooit kiekeboe mogen spelen om te voorkomen dat die bemoelal over zlijn schouder mee zou kijken naar gevoelige formatiekwestles en andere belangrijke staatszaken waar hij even niemand bij nodig had. Ja, dat juist de monseigneur niet van zo'n spelletjes gecharmeerd was, wist hij wel en vond hij achteraf ook volkomen terecht. Maar de grote baas open en eerlijk vertellen dat diens interventie 'n keer niet uitkwam, was gemalkkelijker gezegd dan gedaan.

In 1925 kwam het keerpunt in hun relatie toen Nolens Ruys terzljde schoof om de weg te banen voor een kabinet onder leiding van Collinn.

Het was een "... door mij allerminst bewonderde houding van die ander...", schreef Ruys begin 1926 aan Van Nispen, maar "... mijn Kamervoorzitterschap bevalt mij best. Ik kan binnenskamers meer doen dan vroeger ... Het zal $U$ misschien verwonderen, dat Ik, zooveel "t kan, als belangrijke zaken besproken worden, de clubvergaderingen bilwoon. llk ga dan niet in een hoekje zitten zonder iets te zeggen, maar heb miljne vaste plaats tegenover den Voorzitter [en] $50 \%$ der keeren, dat lk er heengegaan ben, heb ik voorstellen gedaan afwijkende van de zijne ..." 35

Tegenover, zelfs dwars tegenover de voorzitter, zoals tijdens de Vaticaan- 
crisis in 1926 toen Nolens alles in het werk stelde om Colijn weer in het zadel te helpen en Ruys daarentegen zijn uiterste best deed om de formatiepogingen van Limburg en vervolgens van De Geer te laten slagen. Buiten de voorzitter om ten slotte, toen Ruys in 1929 zelf weer mocht formeren.

Van Nispen wierp zich op als bemiddelaar. En zowaar kreeg de oudgezant de gekrenkte grootmeester zover dat deze de rebelse staatsdienaar op 9 september 1930 liet weten: "Gaarne ben ik te Uwer beschikking, morgen of overmorgen. Misschien is het nog het beste 's avonds tegen acht uur Prinsengracht [36, Den Haag, waar Nolens woonde]. Mocht $\mathbb{U}$ een andere plaats of tijd beter conveniëren - mij goed, maar liefst niet aan het departement wegens acoustiek." 36 .

De geluidskwallteit van het Torentje, wat was dáár nou mis mee ? Tenzij de monseigneur natuurlijk ... Met lood in de schoenen en de rozenkrans in de hand toog Ruys naar het hol van de leeuw.

Het gesprek liep uit op een gewapende vrede. Nooit gingen de heren meer samen naar Scheveningen, maar uit erkentelijkheid voor weleer, vermaakte Nolens Ruys wèl een schillderij !

Tijdens de herdenking van Nolens in de Tweede Kamer zegt Ruys op 15 september over "een van [haar] meest uitstekende leden": "Een moeilijk leven als van den Staatsman Nolens ware niet zoo te leven geweest, indien het zijn uitgangspunt niet had gevonden in, en zijne dadenrijke stuwkracht niet telkens weer had ontleend aan de diepe overtuiging van den priester Nolens ... In het klare besef van zijne menselijke verantwoordelijkheid is hij de eeuwigheid tegemoet getreden als de voorzichtige Nolens, die zich niet nauwgezet genoeg op al zijne beslissende stappen en daden kon voorbereiden ... Als ooit van een mens van zijn onmiskenbare invloed kan worden getuigd, dat hij gaaf en onkreukbaar in het leven stond, dan moet dit van den overledene worden gezegd." ${ }^{37}$ Het tijdperk Nolens is voorbij. Zijn op de toekomst voorbereide fractiesecretaris Aalberse is zijn natuurlijke politieke erfgenaam.

\subsection{Wegwelteren}

De verslechtering van het economische klimaat heeft vanzelfsprekend ook haar weerslag op de toestand van 's Rijks financiën. De staatsinkomsten lopen sterk terug en ondanks de strakke beteugeling van de uitgaven komt De Geer bij de opstelling van de begroting voor 1932 uit op een voorlopig geraamd tekort van $f 75$ miljoen. 
De ministerraad hanteert vervolgens het snoeimes, dat de uitgaven weliswaar vele miljoenen uitdunt maar altijd nog een gat van $f 49$ miljoen in de begroting laat die De Geer op Prinsjesdag presenteert.

Wel heeft het kabinet voor de bestrijding van dat schrikbarend hoge begrotingstekort van ruim $8 \%$ nog wat anders achter de hand. Het is van plan het deficit alsnog naar $f 20$ miljoen terug te schroeven, maar dan moet het parlement natuurlijk niet moeilijk gaan doen over een salariskorting voor de ambtenaren, een benzinebelasting en een verhoging van invoerrechten.

De miljoenennota is nauwelijks op tafel of Engeland en - in zijn voetspoor - de Scandinavische landen stappen van de Gouden Standaard af.

De devaluatie van het pond en die andere valuta's is een zware slag voor de Nederlandse export en betekent ook dat De Geer zijn middelenraming met $f 20$ miljoen moet verlagen.

De begroting voor 1932 hangt nu wel heel erg uit het lood. En daarbij is er nog alle kans op nieuwe tegenvallers, die het tekort naar recordhoogte dreigen te tillen. Het kabinet is er zich van bewust dat broddelwerk niet helpt om tekorten en negatieve trends te keren, nu de hachelijke situatie noopt tot een structurele aanpak van de problemen.

Op voordracht van Ruys besluit de ministerraad van 24 oktober 1931 een staatscommissie in te stellen, met de opdracht: " ... binnen zoo kort mogelijken termijn aan Ons zoodanige voorstellen te doen als in verband met de noodzakelijkheld van een blijvende en aanzlenlijke verlaging van het peil der Rijksuitgaven dienstig zullen zijn te achten." ${ }^{38}$ En zo begint eind oktober een staatscommissie met een zware vertegenwoordiging uit de wereld van wetenschap, bedrijfsleven, financiën en ambtenarij, onder voorzitterschap van de oud-vice-president van de Raad van Indië, Ch. Welter, de rijksbegroting uit te spitten. Wegwelteren, liefst zoveel mogelijk!

\section{* Uit bittere noodzaak}

Terwijl de staatscommissie-Welter grondig aan het spitten is, werken kabinet en parlement een druk programma af.

De benzinebelasting: $4 \frac{1}{2}$ cent bovenop de prijs van 6 cent. Dat kan wel lijden na een prijs die vorig jaar nog 18 cent bedroeg!

De eerste slag is binnen. Minder vlot verloopt het met het salarisoffer dat het kabinet van de rijksambtenaren en de onderwijzers vraagt. De linkerzijde is fel tegen de voorgenomen regeringsmaatregel en geeft daaraan uiting in een motie-Marchant, die de salariskorting onder de gegeven om- 
standigheden niet-gerechtvaardigd oordeelt. Ook in de katholieke kamerfractle is men allerminst ingenomen met de kortingsmaatregel. Aalberse, net tot gezagvoerder gekozen, moet meteen al alle zeilen bijzetten om zijn hele club binnen boord te houden. Pas als De Geer hem toezegt, de ingang van de salariskorting bij wijze van uiterste concessie twee maanden uit te stellen, lukt het hem de dwarsliggers in zijn fractie ervan te weerhouden met de oppositie mee te stemmen.

Met 58 tegen 34 stemmen legt de salarismotie vervolgens op 12 november 1931 het loodje. En zo weten dus alle rijksambtenaren en onderwijzers wat hun te wachten staat. Bijna alle althans, want bij de behandeling van de onderwlijsbegroting van minister Terpstra richt Lingbeek op 15 december het zoeklicht op een Sonderkategorie: de onderwijzer-kloosterling. Deze strijkt wel mool het normale salaris op, terwijl de gelofte van armoede hem gebiedt met al dat geld de kas van zijn orde te spekken. Roomse hebzucht noemt Lingbeek zolets. En net als blij de begrotingsbehandeling van verleden jaar trekt hij dan ook fel van leer tegen dat schreeuwende onrecht.

Toen de vorige keer ook diverse andere kamerleden de monnikenarbeid meer in de sfeer van het liefdewerk wilden trekken, verklaarde minister Terpstra zich bereid te onderzoeken in hoeverre het behoefte-element hoort mee te tellen bij de vaststelling van de onderwijzerssalarissen. ${ }^{39}$ Als er in de onderwijsbegroting voor 1932 geen resultaten van het onderzoek zichtbaar zijn, komt Lingbeek op de zaak terug. Op zijn vraag hoe het met het onderzoek staat, antwoordt de minister hem dat de commissieWelter daar volop mee bezig is. Even geduld dus. Een paar maanden slechts, maar dan krijgen Lingbeek c.s. ook hun beloning voor het wachten als de commissie - met uitzondering van haar katholieke naamgever - het kabinet adviseert over te gaan tot strakke toepassing van het behoefteelement.

De netelige kwestie ligt nu weer op het bordje van de politiek. Een advies overnemen dat wat oplevert, is natuurlijk altijd leuk meegenomen. Maar ja, dat spreekwoord van gelijke monniken ... En stel nou eens dat de buitenlandse arbeiders die hier werken, net a/s wij recht zouden hebben op 'n kindertoelage. Zouden we dan voor hun in een "goedkoopteland" achtergebleven kroost óók het behoefte-element ...?

Nee, toch maar niet I Maar de financiële nood blijft intussen wel dringen en dus gaat het politieke dubben over een dubbele korting op het salaris van de docerende kloosterlingen nog jarenlang door.

Tot in 1941 een eind komt aan een tijdperk van ambivalentie en scrupule. jedem das seine, heet dat in het onheilspellende nazi-jargon. En in een handomdraal is het monnikenloon met $40 \%$ reduziert. ${ }^{40}$ 
De salarissen van de rijksambtenaren en het onderwijzende personeel gaan nu per 1932 wel gemiddeld met ruim 3\% achteruit, maar voor het kabinet is dat niet méér dan een halve maatregel als tegelijkertijd niet ook de ambtenaren in dienst van de provincles en de gemeenten inleveren.

Het is immers crisistijd en in zo'n situatie moeten ook de lagere overheden extra zuinigheid betrachten. Het kabinet zit overigens wel met het probleem dat het als centrale overheid niet over het wettelijke instrumentarium beschikt om decentraal vastgestelde salarissen rechtstreeks te korten, omdat de bezoldiging van de ambtenaren bij de provincles en de gemeenten nu eenmaal een zaak is van het "bevoegde gezag" van deze lagere organen.

Als rechtstreeks ingrijpen niet gaat, wil het kabinet de indirecte dwang wel proberen. Het stelsel van de rijksuitkeringen biedt immers volop mogelijkheden om kwistige provincles en gemeenten terug te fluiten. En zo ligt nu een wetsontwerp voor dat die openbare lichamen een korting ter grootte van $3 \%$ van hun salarisuitgaven in het vooruitzicht stelt. Volgens de memorie van toelichting heeft die maatregel echter geenszins de bedoeling het "bevoegde gezag" zijn recht op hantering van eigen bezoldigingsnormen te ontnemen. Want elke provincle en gemeente mag gewoon zelf bepalen op welke uitgaven zij die korting toepast !

Het parlement is niet zuinig met zijn kritiek op het ontwerp. In beide kamers verwijten links en rechts De Geer dat hij met zijn kortingsmaatregel al binnen een jaar na de Inwerkingtreding van de financlële-verhoudingswet zit te morrelen aan de voor vi|f jaar vastgelegde - zil het niet uitdrukkelijk gegarandeerde - uitkeringen ult het gemeentefonds. Ook de kortingsgrondslag van het ontwerp zit een deel van de parlementariërs niet lekker. Zij zien daarin een opschuiving in de richting van een grotere centralisatie, waardoor het gedecentraliseerde (deel van het) ambtenarenrecht op de tocht komt te staan.

De Geer moet ten slotte in beide kamers naar de reddingsboel van de portefeuillekwestie grijpen om zich te verzekeren van voldoende rechtse en liberale steun voor de verkapte ingreep van de rijksoverheid in de provinciale en de gemeentelijke salarissen.

Na de benzinebelasting, de salariskorting en de verlaging van de rijksuitkeringen, die samen het begrotingstekort met zo"n $f 18$ miljoen moeten drukken, gaat De Geer in één adem verder met een operatie dle tot rulm $f 10$ miljoen meeropbrengst moet leiden.

Het volgende plan dat hij in november op tafel legt, betreft het tarlef van invoerrechten, dat hij van $8 \%$ op $10 \%$ wil brengen. De minister verwacht 
van deze maatregel niet een zodanige belemmering van het internationale handelsverkeer dat het buitenland tot repercussies zal overgaan. Voorwaarde is dan wel dat de kamer niet aan de vrijdom van invoerrechten op allerlel buitenlandse producten gaat tomen, met het doel de afzet van binnenlandse voortbrengselen te begunstigen.

Het is Lovink, de voorzitter van de commissie die vorig jaar de overheidssteun aan de landbouw op gang bracht, die opnieuw voor de noodlijdende agrarische sector in de bres springt. De minister kan nu wel waarschuwen voor protectionisme, betoogt de landbouwexpert, maar buitenlandse producten die hier zonder invoerrecht op de markt mogen komen, doen het binnenlandse aanbod oneerlijke concurrentle aan. Als gevolg daarvan kampen de producenten van aardappeis en vlees momenteel met grote afzetproblemen. De toestand dreigt onhoudbaar te worden als de wet niet verandert. En dus rest Lovink niets anders dan een amendement in te dienen om te trachten aan die belastingvrije invoer van aardappels en vlees een eind te maken.

De Geer is er niet gelukkig mee dat het amendement-Lovink het fiscale karakter van ziljn ontwerp vermengt met protectionistische elementen. Bovendien is het nog maar de vraag of het wijzigingsvoorstel het beoogde effect zal hebben. Ook de kamer is daar niet zo zeker van. Willen we voorkomen dat buitenlandse handel en nijverheid onze markten overspoelen, dan helpt alleen een invoerbeperking, menen Colijn en Oud.

Toch is die stellige opvatting van twee collega's geen reden voor een meerderheid van rechts en de liberalen om het wetsontwerp, inclusief het amendement van Lovink, af te stemmen. Want waarom zou je als kamer de kans op meer invoerrechten laten schieten als het alternatief: contingentering van de invoer, evenzeer koffledikkijken is? En in de Senat verkondigt een rechtse meerderheid al net zo'n wijsheid.

\section{* Een nationale wet}

Koesteren rechts en links tot dusver voornamelijk hun eigen gelijk waar het gaat om de crisisbestrijding, wonder boven wonder kent eind 1931 een moment van zeldzame eensgezindheid.

De moodtoestand geeft daar trouwens ook alle aanleiding toe. De boerenstand verpaupert, de scheepvaart lijdt zwaar verlies, negenduizend winkeliers zijn inmiddels failliet, de industriële bedrijvigheid is sinds 1929 met $30 \%$ gedaald en bij dit alles is het werkloosheidscijfer al tot een kwartmijoen gestegen.

In een tijd van "nationaal gevaar" heeft het land breed gedragen "nationale wetten" nodig. Met deze aansporing introduceert minister Verschuur 
in december zijn ontwerp-crisisinvoerwet. In het verlengde van de wet inzake verhoging van invoerrechten machtigt de crisisinvoerwet de regering, paal en perk te stellen aan overmatige invoer van door haar aan te wijzen goederen. De huidige buitengewone omstandigheden dwingen ertoe onze handelspolitiek tijdelijk aan te passen om het bedrijfsleven van de ondergang te redden. Bovendien heeft de regering, aldus Verschuur, met invoercontingenten een onderhandelingswapen in handen in de handelspolitieke strijd met buitenlandse regeringen.

Wie vrijhandel voorstaat, is lemand die in een tijd van economische crisis concessies aan zijn principe moet doen. Oud en zijn vrijzinnig-democratische fractie niet uitgezonderd. Voor hem en de zijnen mag het ontwerp wel passeren, onder de voorwaarde dat de kamer instemt met zijn amendement, strekkende tot parlementaire bekrachtiging van de contingenteringsmaatregelen.

Nu "nationaal gevaar" dreigt, kent de Tweede Kamer haar plicht: amendement en wetsontwerp gaan er zonder hoofdelijke stemming door. Ook in de Senaat heerst voor de gelegenheld de consensusgedachte.

Met een "nationale wet" als steun in de rug kan Verschuur gesterkt de aanval inzetten op overmatige invoer van goederen, die hier onze bedrijven kapotmaakt.

Nog op veel meer gebieden moet het kabinet zijn aandacht richten. Zo heeft de export veel last van buitenlandse deviezenbepalingen die het betalingsverkeer aan banden leggen. Begin 1932 machtigt een noodwet de regering, internationale verdragen te sluiten die de financiële afhandeling van handelstransacties tussen Nederlandse en buitenlandse bedrijven, met uitsluiting van het rechtstreekse betalingsverkeer in handen leggen van de wederzijdse centrale banken. Als zogenaamde clearinginstituten hebben deze banken tot taak de bedragen van in- en uitvoer van de desbetreffende landen onderling te verrekenen om zodoende deviezentransactles zoveel mogelijk te vervangen door betaling met gesloten beurs.

Ook bereiken het kabinet noodsignalen uit de hoek van de scheepvaart. Deze bedriffstak ondervindt veel nadeel van de terugloop in de handel en van de gunstige condities waartegen vervoerders in landen met een gedevalueerde munt hun diensten kunnen aanbieden. Als gevolg van het sterk gedaalde aanbod van vrachten draaien diverse scheepvaartmaatschappi|en die hun capaciteit aan scheepsruimte onvoldoende kunnen benutten, met groot verlies. Overheidssteun is geboden, en komt ditmaal in de vorm van financiële deelneming in de Benas, een maatschappij tot behartiging van nationale scheepvaartbelangen, die zich vanaf 1932 gaat bezighouden met reorganiseren en afslanken van de handelsvioot. 
Uit bittere noodzaak keren in 1932 de twee jaar geleden met veel ophef afgeschafte opcenten op de suikeraccijns weer terug. Het crisisfonds is namelijk leeg en heeft die extra heffing op suiker en diverse andere consumptieartikelen hard nodig om crisiskosten te bestrijden. Ooit was het fonds een goed gevuld reservepotje. Maar oppotten is er tegenwoordig niet meer bij !

\section{* Instrumenten voor de crisisbestrijding}

Het is bepaald geen niemendalletje dat Ruys voorjaar 1932 van commissievoorzitter Welter in ontvangst mag nemen.

Als resultaat van haar spitwerk komt de commissie in haar rapport van liefst 450 bladzijden met het voorstel $f 100$ miljoen op een begroting van rond de $f \mathbf{5 9 0}$ miljoen te bezulnigen. En alsof dat al niet drastisch genoeg is, zien Welter c.s. hun voorstel nog maar als "een eerste schrede op de moeilijke weg der budgetverlaging, die spoedig door een tweede stap van niet minder verre strekking gevolgd zal moeten worden." ${ }^{41}$

Het kabinet is op zijn wenken bediend en het maakt bij het opstellen van de begroting voor 1933 meteen ook dankbaar gebruik van de chirurgische instrumenten die het rapport aanreikt.

Het is Verschuur die op het moment dat de crisis het maatschappelijke en economische leven meer en meer in haar greep krijgt, in de ministerraad een krachtig pleidooi houdt voor een geïntegreerde aanpak van de crisisbestrijding.

Zowat elk ministerie, rekent Verschuur voor, heeft zijn eigen sociaaleconomisch winkeltje. Buitenlandse zaken bemoeit zich onder andere met buitenlandse handelsbetrekkingen, financiën met invoerrechten en subsidies, arbeid met invoercontingenten en werkloosheidsverzekering, binnenlandse zaken met werkverschaffing en steunverlening, landbourw met visseril, enz. Besluit de raad niet tot een herschikking van diverse portefeuilles, dan kunnen we een consistent economisch-herstelbeleid wel vergeten, waarschuwt de minister van arbeid, handel en nijverheid.

De spreker maakt er geen geheim van waar hij heen wil. Schreef hij anderhalf jaar geleden al niet in zijn brandbrief aan Ruys: "... gelooft men in de [zware] economische taak, welke de Regeering wacht en welke reeds lang aanwezig is .... dan onthoude men mil niet de instrumenten om deze te vervullen ..." ? ${ }^{42}$

Ruys deelt de bezorgdheid van Verschuur. Zelf beheert de kabinetsleider een portefeuille die met zijn mix van binnenlands bestuur en agrarische zaken nogal heterogene aandachtsvelden en culturen omvat. Als na enige 


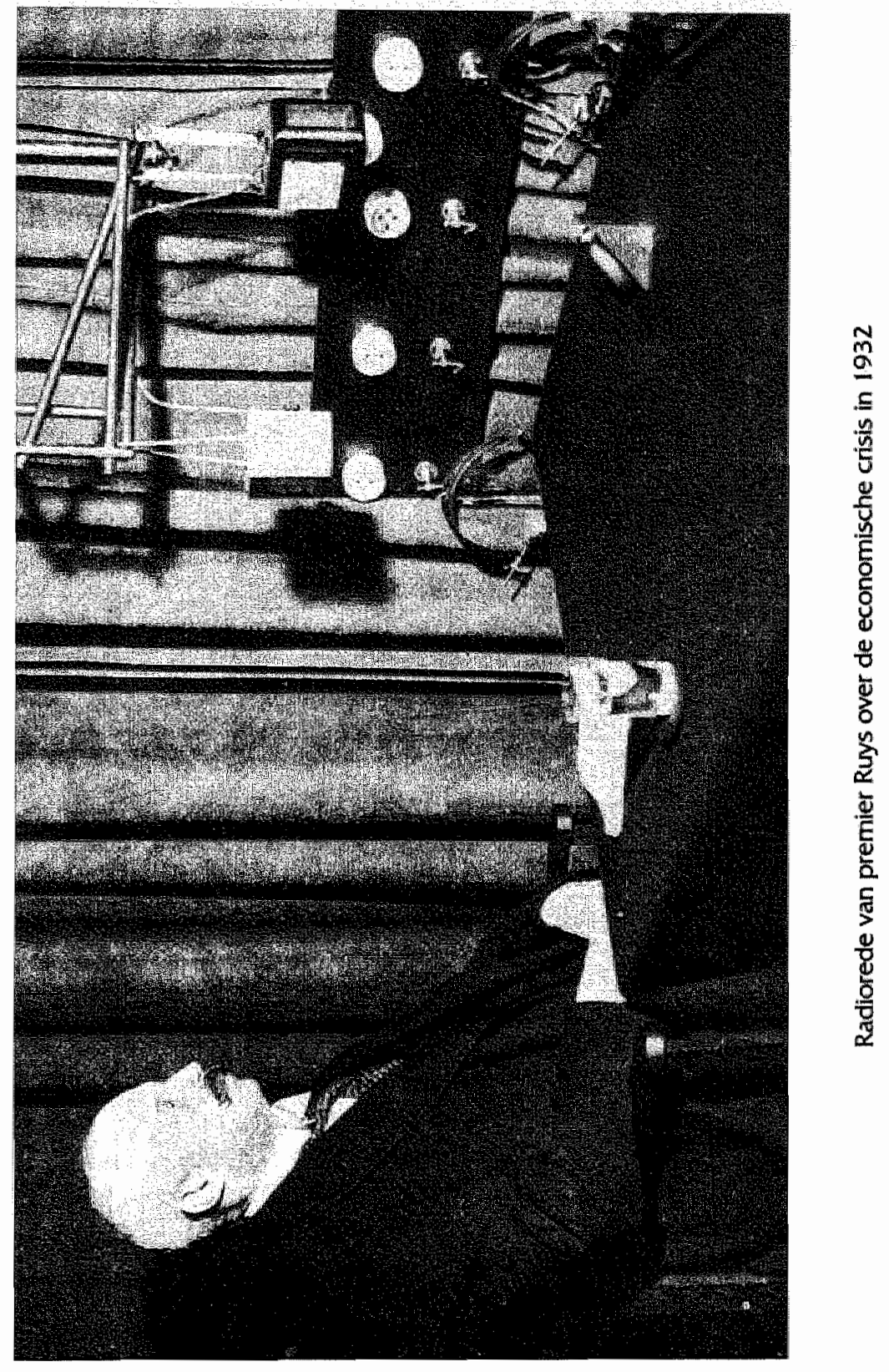


herverkaveling van taken op 1 mel 1932 de nieuwe departementale indeling ingaat, behoort alles wat te maken heeft met landbouw, visseri]. scheepvaart, arbeld, handel en nifverheid tot het werkterrein van het tot economische zaken en arbeid omgedoopte ministerie van Verschuur.

Nog in dezelfde maand kondigt de nieuwe "superminister" steunmaatregelen voor de varkenshouderij af en opent hij een crisiszuivelfonds, dat de melkveehouderij een minimumprijs moet garanderen. De leiding van economische zaken en arbeid is in handen van een man die ontegenzeglijk van doorpakken houdt !

\section{* De initlatlefwet van Ebels}

Het parlementaire jaar 1931-1932 loopt ten einde en nog steeds is de oplossing van het aloude pachtvraagstuk niet in zicht.

Sinds een rechts-liberale meerderheid in de Senaat zich tegen de napachtregeling verklaarde en om die reden in februarl 1932 de pachtwet afstemde, komt dit onderwerp niet meer op de agenda van de ministerraad voor. Het met rooms-rode steun aanvaarde amendement-Fleskens, dat rechterlijke toetsing van pachtprijzen mogelijk maakte, veroorzaakte immers een scheiding der geesten in de regeringsgezinde fracties in beide kamers. En zonder voldoende draagulak in de eigen achterban is de door het kabinet beoogde definitleve regeling van de pacht dan ook een illusie. Zodra het de Tweede Kamer duidelijk is dat het kabinet in de verwerping van de pachtwet berust, neemt zij zelf het heft in handen. De vrijzinnigdemocraat Ebels komt met het initiatlefvoorstel dat voor een pachter van een hoeve of los zand, wiens contract van vóór 1 januari 1932 dateert, de mogelijkheid opent, telkens als een pachttermijn vervalt bij de kantonrechter vermindering van de pachtprijs te vragen. Was de - geamendeerde pachtwet voor menig volksvertegenwoordiger lets ongehoords, met de tijdelijke steun dle de crisispachrwet de noodlijdende pachter wil bleden, gaat het hele parlement echter vlot akkoord.

En zo verschijnt de crisispachtwet, na haar bekrachtiging door de regering, op 21 juni 1932 in het Staatsblad (nr. 308). Dus tòch een lichtpuntje aan het slot van dit bittere parlementaire jaar? Nee, dat lijkt er niet op. Midden juni sterft immers Theodoor Heemskerk in het harnas, nadat de $\mathrm{Ne}$ derlandse politlek in april ook al een andere kanjer, oud-onderwijsminister Johan Theodoor de Visser, is ontvallen. En ook de crisispachtwet stemt niet tot opgewektheid. Althans niet van de tuinder wiens verzoek tot pachtvermindering op 14 november 1932 door de Hoge Raad (N.). 1932 , blz. 587) wordt afgewezen. De geschiedenis van de totstandkoming van "deze in het gemene recht diep ingrijpende wet" zou er, volgens het 
hoogste rechtscollege, op dulden dat huur van een hoeve of los zand nlet op tuinbouwgrond stat.

Dit is een ronduit verblysterend arrest, schrift pachtdeskundige Van Nispen. ${ }^{43}$ En dat ook schoonvader Ruys behoorlijk ontzet is over de vormcrisis van de derde macht, billkt uit een wetje dat de beweerde lacune als de wiedeweerga aanvult.

\subsection{Duistere tijden}

Ook de troonrede van 20 september 1932 kan niet op een lichtpuntje wijzen. De koningin spreekt van duistere tijden dle het vaderland beleeft. "Zonder voorbeeld in de geschledenis zijn de economische verhoudingen over heel de wereld ontredderd. De werkloosheid, bron van zoveel leed, heeft een nooit gedachten omvang aangenomen..." 4 "4

De woorden van Hare Majestelt zign - helaas - maar al te waar. De wolken. twee jaar geleden nog toekomstiand, hangen als een onhellspellend donker wolkendek boven het komende begrotingsjaar. De crisis zet onverbiddelijk door, met alle gevolgen voor de werlloosheid, bron van zoveel leed.

En leed is er volop, zoals een tijdsbeeld van een gezin met man, vrouw en drie volwassen zonen laat zien. De man is sinds 1930 werkloos en ziln drie kinderen wachten nog steeds op hun eerste baan. Senior is een van de 350.000 geregistreerde werklozen en de jongelul horen tot het drie-maal zo grote leger van de niet-ondersteunde werklozen. Het whertal is verplicht zich dagelijks om halfdrie in het stempellokaal te melden, omdat zi) anders de gezinsuitkering van $f \backslash 17$ per week wel eens met "zwartwerken" zouden proberen aan te vullen. Na aftrek van de huur en de ztekenfondsbijdrage houdt het gezin van vilf personen nog $f 12,50$ over om van te leven. Ja, soms kunnen de jongemannen legaal een paar gulden bilverdienen als de werkverschaffing hen toevallig nodig heeft. Maar het totale steunbedrag dat het gezin ontvangt mag dan niet uitstilgen boven $65 \%$ van het loon dat de vader zou verdienen als hij nog werk had. En ten slotte heeft het gezin van november tot april - de veronderstelde koudeperlode nog recht op een brandstoffentoeslag.

Het is armoe troef. Boter, melk, kaas, suiker, groente en fruit moet het gezin zich steeds vaker ontzeggen, terwijl vlees hooguit eens per maand en eieren alleen nog met pasen op tafel komen. En geld voor kleding, schoenen en hulsraad is een luxe die er vrijwel altijd bij inschiet.

Dit is echter niet het enige gezin dat zijn bestaanszekerheid in duigen ziet vallen, zich buitengesloten voelt, doelloos rondhangt en in doffe apathle 
wegzinkt. Honderdduizenden lotgenoten zijn er al net zo beroerd aan toe.

\section{* Den Haag in rep en roer}

Prinsjesdag heeft dit jaar een nogal roerig verloop in Den Haag. Zelfs in de Ridderzaal is de gebruikelijke feestelijke stemming ditmaal ver te zoeken. Bij herhaling overstemmen de twee communisten de troonrede met scheldkanonnades op "de hongerregering van Ruys", zonder dat de voorzitter van de verenigde vergadering. De Vos van Steenwijk, ingrijpt. Wellicht om erger tumult te voorkomen, want probeer gestaalde lieden als Lou de Visser en David Wijnkoop maar eens netjes te verwijderen! Ook elders in Den Haag is de spanning om te snijden. Communisten en socialisten trekken massaal de straat op om tegen de plannen van de regering te ageren. En waar tijdens verhilte protestclemonstraties de kans om te knokken voor het grijpen ligt, laten hordes NSB-ers en ander geüniformeerd extremistisch gespuis vanzelfsprekend nooit verstek gaan. Prinsjesdag is al lang voorbij voor bloedig Den Haag weer de keurige hofstad is.

Met gebruikmaking van een groot aantal voorstellen van de commissieWelter lukt het De Geer een begroting voor 1933 te presenteren die van het voorlopig geraamde tekort van zo'n $f 145$ miljoen nog "maar" $f 40$ miljoen overlaat. Naast bezuinigingen voor een bedrag van $f 70$ miljoen op onder meer de overheidssalarissen, de verzekeringsfondsen, het vlootplan en het onderwijs, rekent de minister op $f 35$ miljoen extra inkomsten ult een weeldebelasting en een tijdelijke heffing van opcenten op het tarief van invoerrechten.

Verhoging van invoerrechten! Laat het geheugen de minister in de steek ? Wat kostte het hem vorig jaar ' $n$ moelte om een tariefstijging van twee procentpunten door het parlement te slepen, en nu doet hil daar doodleuk nog eens drie punten bovenop. En notabene van de zomer sloot Nederland nog een tarlefverdrag met België en Luxemburg. Bij dit verdrag van Ouchy, een stadsdeel van Lausanne, verplichtten de drie landen zich hun invoerrechten en contingenteringen over en weer - en tegenover later toetredende landen - in een periode van vijf jaar na de inwerkingtreding van het verdrag te halveren.

Het duizelt Collijn, en met hem het merendeel van de kamer, dat het kabinet Ouchy tekent en meteen daarna de tariefmuren wil optrekken. $\mathrm{Hi}$ is van mening dat het kabinet volkomen in strijd met de geest van Ouchy handelt door het buitenland met versterkte restrictiemaatregelen te confronteren. Zijn fractie zal het wetsvoorstel dan ook niet steunen. 
Aalberse reageert verontrust op de woorden van Colijn. Als de AR en de linkerzijde straks de tariefstijging afstemmen, valt immers een belangrijke pijler van de begroting weg. Of het kabinet vervolgens bereid en in staat is voor vervangende dekking te zorgen, Aalberse heeft er een hard hoofd in. Alleen uitstel van de beslissing over het wetsvoorstel kan voorkomen dat de boel op dit moment in het slop raakt. En met een motie van die strekking krijgt de katholieke-fractlelelder de hele kamer mee.

Komt tijd, komt raad. De hoop van Aalberse gaat inderdaad in vervulling. $\mathrm{Na}$ intens beraad van Ruys en De Geer met de top van de drie rechtse fracties komt een oplossing uit de bus, die èn de schatkist èn Ouchy eer aandoet. De tariefstliging zal zich beperken tot goederen die geen deel uitmaken van het wederkerige handelsverkeer, terwijl de fiscus als compensatie voor deze verliespost mag rekenen op meeropbrengsten uit een verhoogd suikeraccijns.

Nu groot rechts weer op één lijn zit, is het voor De Geer vervolgens een koud kunstje om de herziene belastingmaatregelen binnen te halen.

\section{* Het kabinet onder vuur}

Het kabinet krijgt in het algemene politjeke debat van najaar 1932 harde woorden over zich uitgestort.

Zo is voor de liberalen de maat vol. $\mathrm{Zij}$ hebben geen greintje fiducle meer in het beleid van het kabinet dat terugdeinst voor harde bezuinigingsmaatregelen, de salarissen en de lonen teveel ontziet en het bedrijfsieven aan zijn lot overlaat.

"Ons vertrouwen in dit Kabinet", spreekt mr. H.J. Knottenbelt, "is volkomen verloren gegaan. Een Kabinet van dezen oorsprong en structuur, wankelend steunend op de rechterzijde, ... kan de vooral thans dwingend vereischte zelfstandige kracht niet ontwikkelen, kan niet de ijzeren leiding geven, die ons volk behoeft om den nood van deze tijden te doorstaan en te overwinnen ..." 45

Natuurlijk vindt ook Albarda dat het kabinet heeft afgedaan. Het ergste is nog dat het kabinet de vrijheid van betoging met voeten treedt. Ambtenaren kregen geen verlof en werklozen geen ontheffing van de stempelplicht om op 8 november in Den Haag deel te nemen aan de grote protestdemonstratie van de SDAP tegen het regeringsbeleid. En de VARA werd zendtijd geweigerd, waardoor zij de luisteraars thuis niet /ive kon laten horen wat woedende demonstranten zoal schreeuwden: 


\section{"Wie brengt honger in ons huis? \\ Dat is Ruys, Ruys, Ruys ! \\ Whe maakt onze centen zoek? \\ Dat is Ruys de Beerenbrouck!" 46}

Er zit Albarda nog méér dwars. Het valt hem op dat de politie bij ongeregeldheden meestal veel harder optreedt tegen linkse groepen dan tegen fascisten en nationaal-socialisten. Zo meldt zijn partijkrant Het Volk van 12 november dat de politie gisteren in Amsterdam met gummistokken en sabels op rustig betogende SDAP-ers en communisten inhakte en geen poot uitstak toen een troep gewapende zwarthemden in optochtformatie door de stad trok... ${ }^{47}$

Het kabinet meet, volgens Albarda, met twee maten. Linkse demonstraties stuiten steevast op hardhandige ordemaatregelen. Maar als bruin- en zwarthemden de straat terroriseren, laat de politie die "nieuwe orde" lankmoedig begaan.

In zijn weerwoord verklaart Ruys dat de beschuldigingen van Albarda elke grond missen. Het kabinet neemt weliswaar "een zuiver negatieve houding" ${ }^{48}$ aan tegenover demonstraties die, zoals op 8 november, een sfeer van onrust scheppen, maar maakt daarbij geen onderscheid tussen rode, bruine of zwarte manifestaties. Om zelfs de schijn van ongelijke behandeling van groepen weg te nemen, is het kabinet bereid de kamer te volgen in haar wens om het openlijk dragen van "politieke" uniformen of onderscheidingstekens strafbaar te stellen. Met bekwame spoed? Reken maar ! Liefst tien maanden duurt het nog eer een dergelijk simpel artikeltje in het Wetboek van Strafrecht verschijnt !

Van lemand die een time-out aanvraagt om heibel over een invoertarief niet te laten uitlopen op een kabinetscrisis, kan men moeilijk verwachten dat hilj een paar weken later de valbijl hanteert.

Het kabinet zit er zonder onze toestemming en zeker zonder onze medewerking. Over het beleid dat het voert, hebben wij sterke twilfels, maar zolang in de gegeven kritieke omstandigheden geen andere uitweg openstaat, zullen will onze steun aan dit extraparlementaire kabinet blijven geven.

Aalberse is aan het woord. Een halfjaar voor de periodieke Tweede- Kamerverkiezing wil zijn fractie het kabinet niet naar huis sturen. Maar zijn partil zal het ook niet tot inzet van de verkiezing maken. Naar de mening van Aalberse moet het nieuwe kabinet straks steunen op een werkbare parlementaire meerderheid, waartoe samenwerking van de rechterzijde met andere fracties niet bij voorbaat tot de onmogelijkheden behoort. 
Rechts samen met links ? De sociale voorvechter doelt natuurlijk niet op de liberalen, want die zijn hem veel te conservatlef. Samen met de vrijzinnig-democraten, lijkt daarentegen niet onwaarschijnijk. En met de socialisten dan?, vraagt hem een kamerlid dat zich nog vaag het tien jaar oude anti-SDAP-besluit van de RKSP herinnert.

Aalberse, schrijft Gribling, is er "... ondanks alle inspanningen nooit in geslaagd vlot Frans en nog minder vlot Engels te spreken. ledere redevoering in die talen vereiste van hem intensieve voorbereiding ..." ${ }^{49}$ Derhalve bedreven in veelzeggend stilzwijgen, ruimt hij op zijn wijze elk misverstand bij de vraagsteller uit de weg: "Le silence aussi est une opinion." 50 Zoveel is zeker, de RKSP voelt in deze tijd van nationaal gevaar niets voor een nationaal kabinet.

\section{* Gelukkig dat Ruys er nog is ?}

Met de almaar toenemende kritiek op het kabinetsbeleid komt ook de positie van de kabinetsleider steeds meer in het geding.

Reeds in het najaar van $1931 \mathrm{kwam}$ in de katholieke kamerfractie de vraag aan de orde of men het kabinet nog wel kon blijven steunen en Ruys niet beter kon opstappen.

Ook de fracties van de AR en de CHU waren van oordeel dat het kabinet onder de weifelende leiding van Ruys de nodige slagvaardigheid miste om tegen de crisissituatie op te boksen.

Kort daarop bood Ruys de drie fracties aan, in een informeel overleg de crisismaatregelen van het kabinet toe te lichten. De drie kamerclubs hielden echter de boot af. Aalberse moest maar tijdens de algemene beraadslagingen in de kamer tot uiting brengen dat ziljn fractie van het kabinet een krachtigere aanpak van de crisis verlangde. Ook Colijn en Schokking hielden de premier op afstand. Zijn aanbod leek hun overbodig, zeker nu zij de indruk hadden dat de RKSP van Ruys af wilde. ${ }^{51}$

Ja, waar wás Ruys, toen hij in november 1931 de salariskorting van "zij|n" ambtenaren volledig aan De Geer overliet? En waarom sprak hij in februarl 1932 niet het machtswoord vóór een handvol dwarse partiggenoten in de Senaat de pachtwet om zeep kon helpen ? ${ }^{52}$

Zeker, uit solidariteit met de werklozen zat hij in de kille oktobermaand van 1932 thuis met de overjas aan en de sjaal om te werken omdat hij weigerde de verwarming aan te zetten zolang zoveel mensen in het land tot 1 november op hun brandstoffentoelage moesten wachten. ${ }^{53}$ Maar wat schoten die bijna vierhonderdduizend werklozen en hun gezinnen ermee op dat de kabinetsleider zijn "wijs beleid van aanpassing door middel van bezuiniging" zelf in praktijk bracht? 
De staatspartij luidt inmiddels reeds het tijdperk na de regeerperiode-Ruys in. Was "de edelman die werkt voor het volk" in 1929 nog landelijk lijsttrekker, voor de kamerverkiezing van 1933 stelt de partij hem niet meer kandidaat in de grote steden. "Bij het bewuste proletariaat en de intellectuelen der groote steden", commentarieert De Limburger Koerier wrang. "kon men met zoo'n man niet uitkomen: de boeren in Limburg mochten dhr. Ruys wel weer in de Kamer brengen". ${ }^{54}$

Ruys is inmiddels ruim tien jaar minister-president: Al die tijd was hij het paradepaardje van de RKSP, met veel krediet ook bil zijn protestantse coalitiegenoten.

Maar als zijn derde kabinet er niet in slaagt het economische getij te keren, is de boot aan en verwijt men hem van alle kanten zijn falen als "aanjager van noodzakelijk beleid." "25 Zelfs zilin eigen partij is er dan ongelukkig mee dat Ruys er nog is !

\section{* Tot betere tijden}

Minister Verschuur is nog heel wat van plan in het laatste halfjaartje dat het kabinet voor de boeg heeft. Er is hem veel aan gelegen tussen nu en dan de herziening van de ouderdoms- en invaliditeitswetgeving, de uitbreiding van de arbeldswetgeving en de algemeen-verbindendverklaring van collectleve arbeidsovereenkomsten voor elkaar te brengen. Maar het geld is op, en dan moet ook hil plannen die wat kosten, in afwachting van betere tijden in de ijskast bergen.

Budgettair neutraal is wèl zijn ontwerp-bedrijfsradenwet, dat in najaar 1932 in openbare behandeling komt. Het ontwerp opent de mogelijkheid per bedrijfstak een publiekrechtelijke bedrijfsraad in te stellen, die voor een gelijk aantal uit georganiseerde werkgevers en werknemers bestaat en adviesrecht heeft over zakelijke en technische aangelegenheden van het bedrijf.

Van den Bergh (SDAP) is allerminst tevreden over het wetsvoorstel, dat naar zijn mening slechts het zwakst denkbare begin van een nieuwe bedrilfsorganisatie is. De bedriffsraad is een "dorre stam" als men hem geen verordenende bevoegdheid en recht van enquête toekent. Bij amendement doet de sociaal-democraat een poging die dorre stam te laten uitbotten, maar daar krijgt hil de meerderheid van de kamer niet in mee. Wel aanvaardt de kamer een amendement van de katholieke afgevaardigde $\mathrm{mr}$. C. Goseling, dat toekenning van verordenende bevoegdheid aan de bedrijfsraad van een nadere wet afhankelijk maakt. Dit is, aldus Oud, "een beleefde buiging voor die bevoegdheid, meer niet, een herhaling van hetgeen de grondwet reeds [sinds. 1922] bepaalt." 56 
Hoe dan ook, de deur naar decentralisatie op het terrein van de arbeidsregeling staat nu tenminste op een kier. Weliswaar zonder de instemming van de liberale fractie in beide kamers en van de $\mathrm{CHU}$ in de Senaat, maar wèl met de - te elfder ure verkregen - steun van de socialisten, kost het Verschuur weinig moeite de bedrijfsradenwet veilig door het parlement en vervolgens op 7 april 1933 in het Staatsblad (nr. 160) te loodsen.

Wat zeker niet kan wachten tot betere tijden aanbreken, is een gedegen integrale aanpak van de crisis in de agrarische sector.

Het wordt een wedstrijd tegen de klok als Verschuur eind maart 1933 zijn ontwerp-landbouwcrisiswet bij de Tweede Kamer indient. Deze kamer is dan reeds (zoals nader aan de orde komt) "op termijn", per 8 mei aanstaande, ontbonden en de dagen van het kabinet zijn derhalve eveneens geteld.

De nieuwe wet overkoepelt alle voorkomende afzonderlijke steunregelingen, terwijl het kabinet daarbij verstrekkende bevoegdheden krijgt inzake de teelt, de voorraadvorming, de in- en uitvoer en de verwerking van daarvoor aan te wijzen landbouwproducten.

Leuk is het niet voor Verschuur, maar het siert de kamer dat zij vlak voor de afloop van haar mandaat het "kroonjuweel" van de minister niet meer wil behandelen. Een paar maanden later staat de landbouwcrisiswet tòch in het Staatsblad (nr. 261), door toedoen van dezelfde minister, maar nu als lid van een nleuw kablnet èn met de zegen van de nieuwe Tweede Kamer.

\section{* Ook dat nog}

Zondag 5 februarl 1933. In Nederland komt een telegrafisch bericht uit de Indische archipel binnen: "De Zeven Provinciën tijdelijk in handen genomen door de bemanning, alles gaat gewoon zijn gang, stomen op naar Soerabaja, geen geweld in de $z \mid n$, doch protest onrechtvaardige salariskorting en gevangenneming marinemannen Soerabaja, alles wel aan boord." ${ }^{57}$

Zit hiér het kabinet tot over de oren in de problemen met zijn voorgenomen opheffing van een aantal rechtbanken en kantongerechten, gaan dáár in Kota Radja zo'n vierhonderd Nederlandse en Inlandse matrozen er met die oorlogsbodem vandoor !

Ook in Indië slaat de economische crisis hard toe. Het tekort op de binnenlandse begroting wordt van jaar tot jaar groter, en het gouvernement is dan ook gedwongen steeds maar weer meer te bezuinigen.

Het Indische overheidspersoneel en het Koninklijk Nederlands-Indisch 
Leger hebben per 1 januari 1933 al hun derde salarisverlaging in anderhalf jaar tijd te pakken. En het Nederlandse marinepersoneel dat in de Oost onder de wapens is, moet telkens diezelfde trendlijn volgen.

Onder de manschappen heerst grote ontevredenheid over de salariskortingen die de heren in Buitenzorg en Den Haag hun opleggen. Op de marinebasis in Soerabaja komt het bij herhaling tot protestacties en dienstweigering van de bemanning van de oorlogsschepen.

In deze gistende sfeer vaart aldaar op 2 januari 1933 De Zeven Provinciën uit voor een oefenreis naar Sumatra. Drie weken later ontvangen de $\mathrm{Ne}$ derlanders onder het scheepspersoneel in volle zee een levensteken uit Den Haag: als trendvolgers van hun Indische collega's moeten zij óók voor de derde keer inleveren. Bruin en blanda zitten in hetzelfde schuitje !

Op 4 februari legt het schip in de haven van Kota Radja aan. Zodra de commandant en een aantal officleren zich 's avonds voor een feestelijk onthaal aan wal bevinden, maken de matrozen zich meester van het schip en zetten langs de westkust van Sumatra koers naar de thuisbasis Soerabaja.

In de Tweede Kamer verklaart defensieminister Deckers op 7 februari namens de regering dat met geweld tegen de kapers zal worden opgetreden als zij zich "niet onmiddellijk en onvoorwaardelijk na sommatie" overgeven. "Ingrijpende maatregelen zullen worden genomen", vervolgt de minister, "tegen verderfelijke invloeden, die de geesten hebben rijp gemaakt tot aanranding van het gezag, door Landsdienaren, die vrijwillig den plicht op zich hebben genomen, dat gezag te dienen." 58

Met uitzondering van de socialisten en de communisten keurt de kamer de kaping van de oorlogsbodem scherp af en staat pal achter de plannen van de regering om de muiters zo snel mogelijk tot overgave te dwingen.

Diverse kamerleden geven daarnaast onomwonden blijk van hun ergernis over de sympathiebetuigingen waarmee men de muiters in socialistische kringen overlaadt. Zo schrijft Het Volk van 7 februari: "De Zeven Provinci$e n$ is in den donkeren Indischen nacht weggestoomd. De geest van dit machtig gebeuren heeft ook Den Helder aangeraakt en al wappert de driekleur in den mistigen dag van de schepen in de haven, in de hoofden van de honderden matrozen zoemen toch de tonen van de Internationale." ${ }^{59}$ En sociaal-democratisch Tweede-Kamerlid ir. Ch.G.Cramer liet zich een dag eerder uit pure geestdrift over de muiteri] in een openbare vergadering ontvallen: "Het heeft mij verduiveld goed gedaan". ${ }^{60}$

Albarda vindt het $z$ waar overdreven om de matrozen muiterij te verwijten. Hun actie heeft immers geen ander doel dan tegen de onrechtvaardige verlaging van hun salaris te demonstreren. Natuurlijk mag die escapade 
niet te lang duren, maar het heeft geen pas haar met geweld, zoals de minister wil, te stoppen. Laat staan dat men die wilde vaart abrupt beëindigt "door het schip met een torpedo naar de bodem van den Oceaan te zenden", wat Colijn in een vraaggesprek met de liberale krant Het Vaderland het liefst ziet gebeuren. ${ }^{61}$

"Torpedo-Hein", krijgt - goeddeels - zijn zin. Persbureau Aneta meldt vrijdag 10 februari om 10.45 uur: "De Commandant van het Eskader sommeerde radiografisch De Zeven Provinciën tot onvoonwaardelijke overgave, daaraan toevoegende dat anders geweld zou worden gebruikt. De Zeven Provinciën antwoordde met een draadloos telegram, gelijk aan dat waarvan eerder melding werd gemaakt, waaraan werd toegevoegd: "val ons niet lastig". De Zeven Provinciën gaf zich over, nadat het te 9 uur 18 door een bom van een Dorniervliegtuig was getroffen ..." 62

Er zijn 23 doden en 13 gewonden te betreuren. "Wij protesteren tegen de schaamteloze aanmatiging van een gezag", reageert Koos Vorrink, "dat in waarachtige verantwoordelijke leiding van wat in de massa's leeft nog nooit anders dan op de schromelikste wijze is tekort geschoten. Wij protesteren tegen de hondse wreedheid van een gezag, dat gespeend is van elke vorm van waarachtige moed... Wij protesteren en wij weten opnleuw met de grimmige zekerheid, waar in het politieke leven de scheidslijnen lopen ..." 63

Ja, als het om scheidslijnen trekken gaat, heb je an die inkomend-voorzitter van de SDAP een hele goele: "wil" tegenover die "grove, lompe, verwaten gezagskliek"!

Het geschoffeerde gezag weet genoeg. De bladen van de socialistische Arbeiderspers zijn voortaan taboe aan boord en in de kazerne. En bij KB van 22 mei 1933 (Staatsblad, nr. 294) wordt een artikel aan het rijksambtenarenreglement toegevoegd, volgens welk een ambtenaar eervol ontslag kan worden verleend op grond van revolutionaire gezindheid of lidmaatschap van een vereniging die, vanwege haar doelstellingen of middelen waarvan zij zich bedient, de behoorlijke vervulling van zijn plicht als ambtenaar in gevaar kan brengen of schaden.

Een "ambtenarenverbod" dus. Maar dat is in strijd met het grondwettelijke recht tot vereniging, betoogt socialistisch kamerlid Vliegen tegen de (destijds) heersende leer in. In deze leer - onder meer aangehangen door Struycken, Van der Pot en Vegting - regelen de grondrechten de algemene rechtstoestand van de burgers, niet de concrete rechtspositie, nog minder de feitelijke vrijheid van iedere individuele burger. De grondrechten verhinderen dus niet dat de overheid beperkingen die zij in het algemeen nlet aan de gewone burgers kan opleggen, wel onderdeel kan maken van de 
specifieke rechtspositie van de ambtenaren. ${ }^{64}$ Zeker nu "something is rotten in the state of defence", om een verre politieke verwant van Willem Viegen te parafraseren.

\section{* Op termifn gesteld}

Terwij] heel Nederland met ingehouden adem de manoeuvres van het kaperschip volgt, komt het kabinet op 9 februari in botsing met de Tweede Kamer over een ontwerp tot wijziging van de rechterlijke organisatie. Om redenen van bezuiniging op de uitgaven van zijn ministerle wil Donner overgaan tot opheffing van 4 rechtbanken en 39 kantongerechten.

Zelden kregen ministers van justitie in het verleden de handen op elkaar als zil gerechten wilden opheffen. Het was na een strijd van vele jaren dat het minister mr. C.Th. baron van Lynden van Sandenburg in 1877 lukte het hardnekkige verzet tegen de opheffing van 11 rechtbanken en diverse kantongerechten te breken. Ook Heemskerk moest in 1923 de opheffing van de rechtbanken in Heerenveen en Zlerikzee voor de helsdeuren weghalen. En Donner zelf stond tegenover een volstrekt afwijzende kamer toen hil in 192835 kantongerechten wilde sluiten.

Aalberse ziet de kansen van het voorliggende wetsvoorstel uiterst somber in. In een gesprek met Donner adviseert hil hem in elk geval de rechtbanken in Roermond, Almelo en Alkmaar buiten schot te laten. ${ }^{65} \mathrm{En}$ in het vooroverleg dat Donner met de CHU-fractie heeft, krijgt hij te horen dat zij zilin voorstel uit een oogpunt van algemeen volksbelang ontoelaatbaar acht. ${ }^{60}$

Tòch zet de minister zljn plannen door. Als ook de kamer hem niet tot andere gedachten kan brengen, dient de liberaal Boon een motie in, die bezuiniging op kosten van de rechtspleging en de rechterlijke organisatie wel noodzakelijk noemt, maar de wijze waarop het wetsontwerp dat will regelen, van de hand wijst. Namens het kabinet spreekt Donner het onaanvaardbaar uit over de motie, waarna de kamer deze met $5 \rrbracket$ tegen 38 katholieke en antirevolutionaire - stemmen aanvaardt.

Het kabinet bevordert daarop onmiddelilik de ontbinding van de kamer. Ruys neemt in de voordracht die hilj daartoe op 15 februari aan de koningin doet, de volgende motivering op: "In dezen tijd van ongeëvenaard groote moeilljkheden van economischen en anderen aard acht het Kabinet zich niet verantwoord, Uwer Majesteit zijn portefeuilles ter beschikking te stellen. De eenige uitweg is ontbinding van de Tweede Kamer, waardoor het terrein geëffend kan worden voor de vervroegde vorming van een parlementair Kabinet, dat in ons huidig tijdsgewricht zeker niet minder dan onder normale omstandigheden als het meest in overeenstemming met 
ons staatsbestel moet worden geacht." 67

Net als in 1917 voor het eerst werd toegepast bij de ontbinding van beide kamers in verband met de grondwetsherziening, gaat de ontbinding van de Tweede Kamer "op termijn" in, te weten op 8 mel, daags voor het aantreden van de nieuwe kamer. Er treedt dus geen kamerloos tijdperk in. De linkerzijde beschuldigt de regering van een toepassing van het ontbindingsrecht, die tegen het grondwettelijke karakter van het instituut ingaat: In deze conflictsituatie had het kabinet behoren op te stappen. Marchant, Knottenbelt en Albarda beroepen zich daarbij op de negentiende-eeuwse staatsrechtsgeleerde mr. J.Th. Buys, die inderdaad zijn bedenkingen had tegen het "gevaarlijke" ontbindingsrecht, dat "... dikwilils toegepast er feitelijk toe moet leiden om, in strijd met de hoofdbeginselen van ons staatsrecht, de hoogste macht bij het kiezersvolk over te brengen..." 68 Een uitspraak van de kiezers is nu juist wat het kabinet wil, verklaart Ruys. Waar het kabinet het zich in de gegeven kritieke sociaal-economische omstandigheden niet kan veroorloven zijn ontslag in te dienen, is kamerontbinding de enige mogelijkheid.

Ruys en zijn ploeg willen in elk geval tot de kamerverkiezing van 26 aprill volop doorgaan om hun agenda af te werken. En zl| zljn bereid daarna in demissionaire staat datgene te blijven verrichten dat zij in het belang van het Koninkrijk noodzakellijk achten. Tot de opvolgers zich aandienen. 26 mei 1933 is het dan.

Nog nooit werd een kabinet met zo'n immense problemen geconfronteerd, blikt Colijn terug. Hij weet op dat moment nog niet wat hem zelf allemaal boven het hoofd hangt I

\subsection{Balans van vier jaar Ruys III}

Als de depressie maar niet te hard toeslaat "hoeven we ons geen overmatige zorgen voor 1931 te maken.

Het is de geruststellende taal van de miljoenennota in september 1930 , op een moment dat de landbouw zware verliezen $l i d t$, de veeteelt en de scheepvaart hard achteruitgaan en het werkloosheidsclifer de honderdduizend is gepasseerd.

Nederland stat aan de vooravond van een economische crisis, dle later begint dan in andere landen en ook langer aanhoudt dan elders.

Ondanks de alarmerende berichten over instortende economieën in het buitenland, laten het kabinet en het bedrijfsleven zich volkomen verrassen door de omslag van de conjunctuur. Een crisis hiér ? Nee, het economische klimaat van 1930 is niet helemaal wat het zijn moet, er is zelfs sprake 


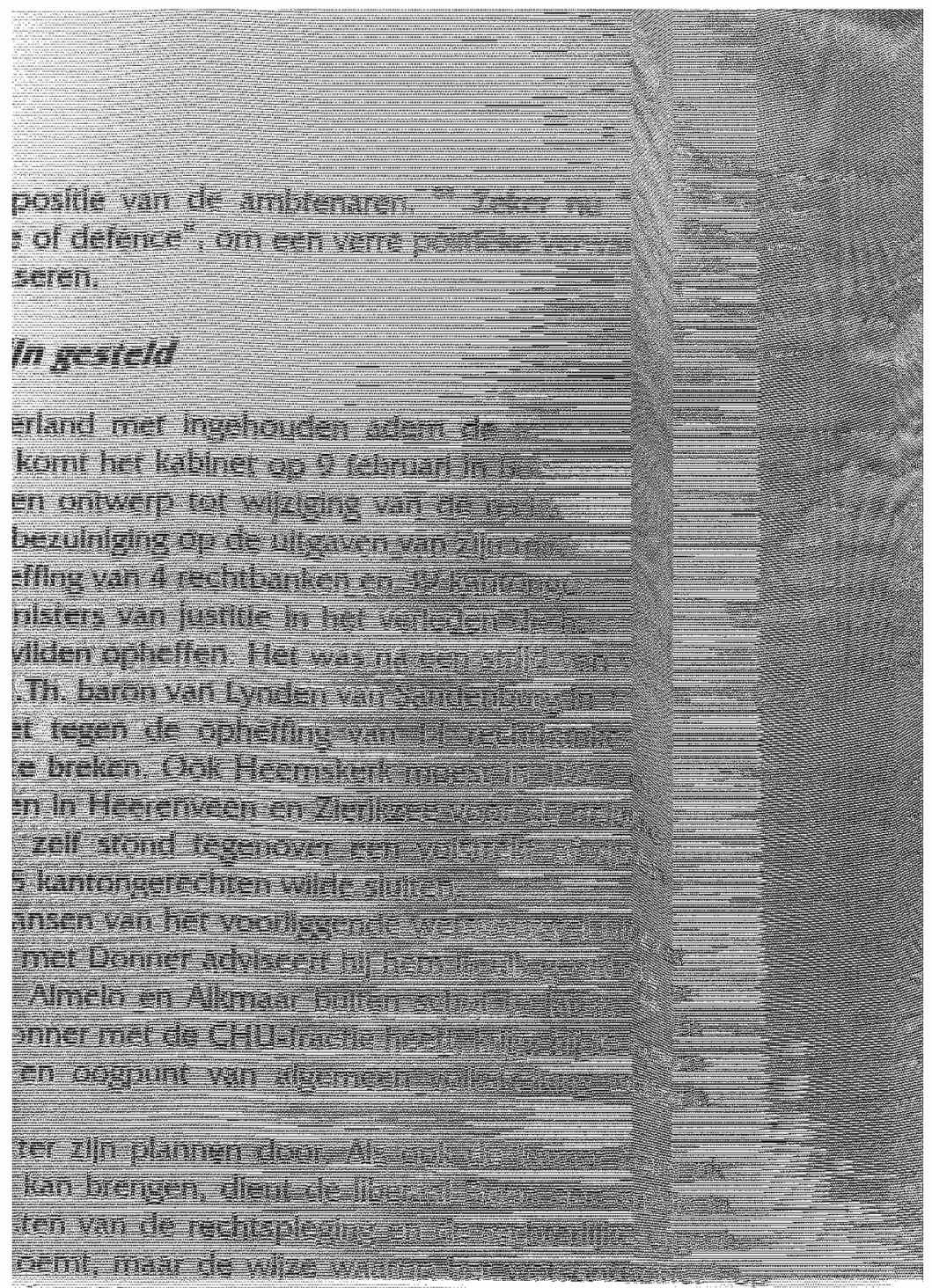

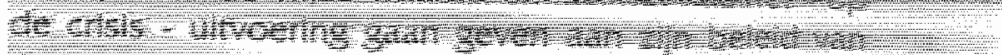
Fits:

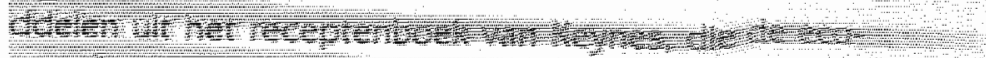

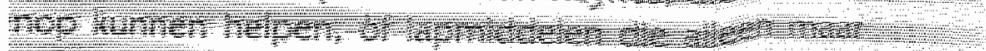
+1)

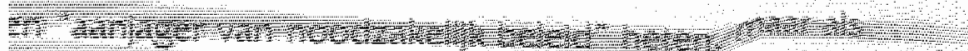

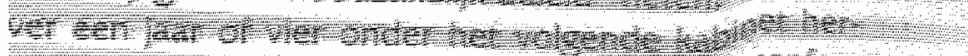

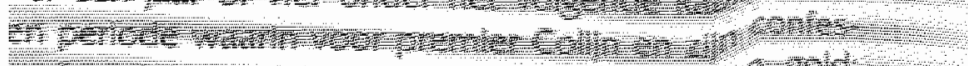

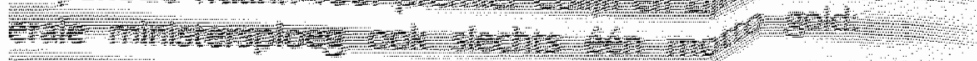
Wy

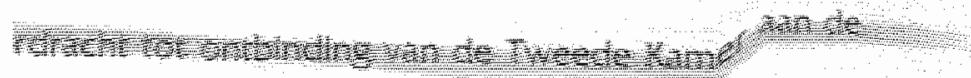


woningin op de "ongeëvenaard groote moelijkheden van economischen en anderen aard", die een vervroegd aantreden van een nleuwe kamer en een (crisis-)kabinet noodzakelijk maken.

Het is nog noolt vertoond dat een kabinet drie maanden vóór de perlodle= ke Tweede-Kamerverkiezing gebruik maakt van ziln ontbindingsrecht om, zonder zichzelf tot inzet van de vervroegde verkiezing te maken, een con= flict met de kamer voor te leggen aan de kiezers. Een onjuist gebruilk van het in de grondwet verankerde ontbindingsrecht? Nee, want het kabinet zag in het kamervotum een onaanvaardbare aantasting van zijn beleid van aanpassing en ordening. En waar de motie-Boon bovendien met de steun van de regeringsgezinde $\mathrm{CHU}$-fractie was aangenomen, mocht het kabinet er niet op rekenen dat er voor zilin andere bezuinigingsplannen wèl een kamermeerderheid zou bestaan. Ontbreekt het aan samenwerking tussen kabinet en kamer, dan kan "wij of zil naar huis" uitkomst bieden. Het kabinet koos voor de laatste oplossing, zonder zlch overigens één dag van de op termin gestelde kamer te ontdoen.

Een regeringscombinatie van bredere samenstelling dan het laatste kabinet-Ruys - tevens her laatste van louter christen-democratische signatuur is in aantocht.

Noodzaak, om nog maar te zwiigen van uiterste noodzaak, maakt rechts en links van nu af aan minder eenkennig in hun partnerkeuze. 


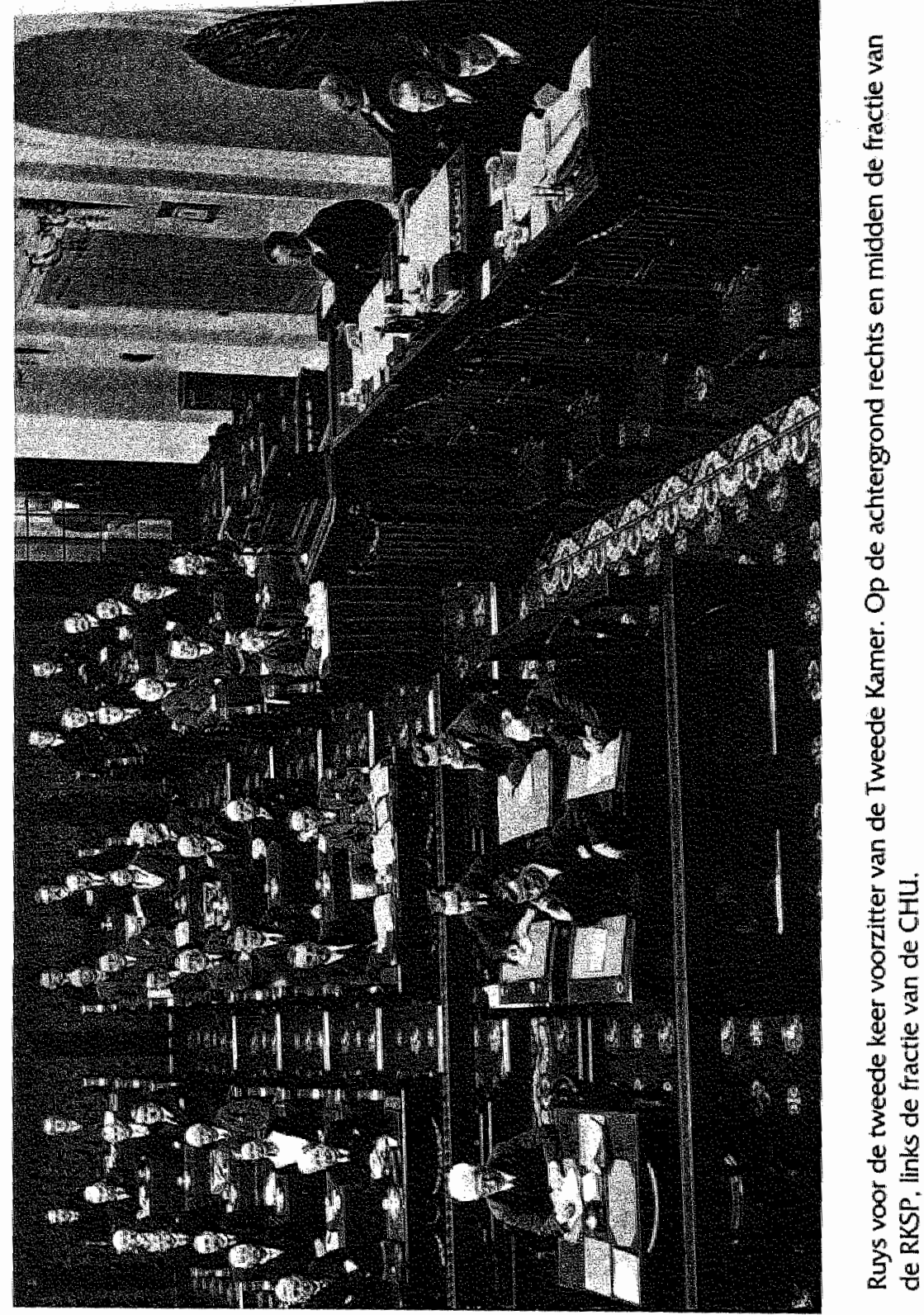


een maand later is de oud-premier opnieuw voorzitter van de kamer, als opvolger van Van Schaik, die minister van justitie is geworden.

Een kamerpresident, terug van vier jaar weggeweest en alom gewaardeerd om zijn onpartijdigheid, zijn kordate en tactvolle optreden, zijn menselijke omgang. Kamergriffier mr. L.A. Kesper over de president: "... Hij deed niet gewild vriendelijk ... hij deed niet mool ... hij "deed" niets ... hil was van eenvoudige hoffelijkheid en hoffelijke eenvoud. Die gelukkige combinatie van hoffelijkheid en eenvoud was het, die maakte, dat leder zich bij hem op zijn gemak voelde..."

"Drie dingen", noteert Ruys in zijn privé-aantekenboekje, "zijn in de wereld moeilijk te leeren: een geheim te bewaren, een beleediging te vergeten en zijn snipperuurtjes goed te besteden." 2

Deze uiting van levenswijsheid van een vertrouwde, milde en altijd bezige man als hij, lijkt eerder de vrucht van omgevingsverkenning dan van zelfonderzoek.

Snipperuurtjes ? Ruys laat tijdens zijn tweede kamerpresidiaat geen uur verloren gaan. Onder impuls van deze plonier van de drankbestrijding komt in 1935 de Wereldbond tegen het Alcoholisme tot stand. In hetzelfde jaar sticht Ruys - en wordt de eerste voorzitter van - de Adelbertvereniging, een katholieke organisatie ter behartiging van de godsdienstigzedelijke, culturele en maatschappelijke belangen van de "hogere standen". Tevens wordt hij in 1935 voorzitter van Het Wit-Gele Kruls, eed nationale federatie van gezondheidszorg, waar zich ook "zijn" Limburgse Groene Kruis bij aansluit. Als edelman-bedelman trekt hij ten slotte het land door om de KRO bij de herdenking van zijn tienjarig bestaan een passend cadeau aan te bieden en fondsen te werven voor de herbouw van de benedictijnerabdij in Egmond.

Gebeurt er intussen ook nog iets bijzonders in politiek Den Haag ? Wat heet ! Op 17 mei 1935 valt het doek over de minister van onderwijs, kunsten en wetenschappen, Hendrik Marchant, als zijn partij hem vanwege zijn overgang naar de katholieke kerk dwingt tot aftreden. Alles heeft Immers zijn grenzen I En dat vindt ook de katholieke minister van economische zaken, mr. M.P.L. Steenberghe, die drle weken later uit bezwaar tegen de monetaire en economische politiek van Colijn opstapt.

Een slecht voorteken voor het kabinet, nu zijn bezuinigingsplannen niet alleen in eigen boezem, maar ook in de katholieke fractie op zwaar verzet stuiten. De meerderheid van de fractie heeft genoeg van de "Colijnpolitiek", die zich beperkt tot bezuinigen zonder aan oppeppen van de economie te doen. Ruys maant de fractievergadering de kritiek op het kabinet 
niet op de spits te drijven: een kabinetscrisis zou in de gegeven omstandigheden een ramp zijn.

Op gematigde toon verklaart Aalberse tijdens het kamerdebat van 17 jull dat de aanpassingspolitiek die het kabinet wil voeren, onvoldoende tegemoetkomt aan de in de katholleke fractle levende wens tot versterking van het sociaal-economische beleid.

De regeringstafel laat geen beroering merken over de weerspannigheid van grootste regeringsfractie tegen de "Colijnpolitiek". Nòg nlet, want de bljeenkomst van vandaag staat in het teken van rouw om het overlijden van een "eerlijk makelaar tussen rechts en links". Kamervoorzitter Ruys in ziln herdenkingsrede: "God zij geloofd voor wat Hij ons in den ontslapene gegeven heeft." ${ }^{3}$ Cort van der Linden, de laatste liberale premier van de twintigste eeuw en stellig ook de grootste liberale staatsman van dat tijdperk, is niet meer.

Twee dagen later reageert Colijn op de woorden van Aalberse. "De Regeering kan niet blijven doorwerken, als haar autoriteit doorlopend ondermijnd wordt door een kritiek, die het voorstelt, alsof onwil en onkunde het beleid van de Regeering beheersen... Daar is nodig een klaar antwoord op de vraag: stelt men nog vertrouwen in het algemeen beleid van de Regeering $\ldots . .7^{\prime \prime}$

Colin wil een vertrouwensvotum, niet het ongewisse van de negatief geformuleerde vertrouwensregel van ons ongeschreven staatsrecht, maar een onomwonden uitspraak van de kamer: ja of nee tegen het kabinet. Aalberse wijst de uitdaging van de premier in zijn antwoord van 23 jull echter af: "Wanneer de door de Regeering gevraagde motle van vertrouwen in het algemeen regeeringsbeleid - waarvan dat op soclaal en economisch gebied thans het voornaamste onderdeel is - wordt voorgesteld en in stemming gebracht, zullen wij daaraan onze stem niet kunnen geven." 5 Colijn II biedt daarop zijn ontslag aan en keert, na een mislukte formatiepoging van Aalberse, op 31 juli in vrijwel dezelfde samenstelling terug als Colijn III. Over het verloop van de formatle en de plannen van het nieuwe kabinet wil Colijn het parlement bij de opening van het zittingsjaar in september wel bijpraten, maar al dit nieuws doet hil op 2 augustus eerst in een radlotoespraak tot het Nederlandse volk uit de doeken.

Dat Colijn aan massacommunicatie voorrang geeft boven overleg met het parlement, zlet men vrij algemeen als een bedenkelijke vorm van directe democratle. Bil de opening van de zitting 1935-1936 van de Tweede Kamer laat voorzitter Ruys duidelijk horen hoe hij over het optreden van de volkstribuun denkt: "... In onze bijeenkomsten spreekt het volk tot de Regeering. Omgekeerd zijn die bijeenkomsten voor de Regeering de aangewezen plaats om tot het volk te spreken." ${ }^{6}$ 


\subsection{Leven zonder te werken, dat kan ik niet}

Maandag 20 april 1936. De kranten berichten dat de Tweede Kamer vandaag op uitnodiging van haar tweede voorzitter, de oud-minister I.J.C. van Dijk, voor een buitengewone vergadering bijeenkomt.

De convocatie bevat geen agendapunten. Vermoedelijk houdt eerst de heer Van Dijk namens de kamer een herdenkingsrede, waarna dan vervolgens de regering het woord voert.

Aan dit zakelijke bericht voegt de Limburgse De Nleuwe Koerier toe: "Omtrent de laatste oogenblikken van den overledene vernamen we nog de volgende bijzonderheden: De toestand van den patiënt liet zich Vrijdag nog niet zoodanig aanzien, dat het ergste te vreezen was. Opname in een ziekenhuis werd echter noodig geoordeeld, waarom Z. Exc. van zijn landgoed "Suideras" naar Utrecht werd vervoerd, om in het St. Antoniuszlekenhuis ter verpleging te worden opgenomen. Nauwelijks had Z. Exc. zich te bed begeven of een zwakte overviel hem, doordat het hart zijn dienst weigerde en na enkele minuten overleed Jhr. Ruljs zacht en kalm. Te voren waren hem nog de laatste $H$. Sacramenten toegediend." 7

Waarnemend kamervoorzitter Van Dijk schetst Ruys als een oprecht Christen, diep belevend het geloof dat zijn plechtanker was, daarnaast ten volle eerbiedigend de levensovertuiging van anderen. Alle partijdigheid bleef verre van hem.

Premier Colijn roemt Ruys' voortreffelijke gaven om meningsverschillen in de boezem van de ministerraad tot overeenstemming te brengen. Het geheel eigene in zijn persoonlijkheid, tevens het meest aantrekkelijke in zijn wezen, was de saambindende invloed die van hem uitging. Hij was tevens een geboren leider van de volksvertegenwoordiging, kon den teugel vieren en hem ook strak aanhalen als het noodig was; nlettemin bleef hij ook in het laatste geval ieders vriend. ${ }^{8}$

leders vriend! "Als minister, zoowel als in zijn functie van voorzitter van de Kamer", schrijft het liberale Algemeen Hande/sblad van 18 april , "heeft de heer Ruijs zich nooit onbilijk of kwetsend tegenover zijn tegenstanders uitgelaten: zijn eenvoudige goedmoedigheid en vooral zljn gevoel voor humor hebben hem vooral als Kamerpresident het aanzien van vrijwel alle partijen doen genieten." Vrijwe/ alle partijen ? Het sociallstische Het Volk doet er nog een schepje bovenop: "Ruys genoot 't aanzien van heel de Kamer, van Ds. Kersten tot Lou de Visser toe. Zoodra het debat rustig en wel aan den gang is, komen leden van de meest uiteenloopende richting naar den voorzitterstoel voor het maken van een praatje. Een advies wordt 
Ingewonnen of een kwinkslag gewisseld." "

leders vriend? "We hielden van Ruils! Als mens was hij correct en sympathlek. Religieus was hil werkelijk een vroom man. Je stond bij Ruijs nooit voor verrassingen in de omgang, hij was gemoedelijk, hartelijk en eenvoudig. Je moest hem vaak een duw geven, maar dan tastte hij ook door, rustig als een waar regent, zonder ooit uitdagend te zijn. Dat laatste was een bijzonder sterk punt bij Ruijs." , vertelt de christelijk-historische politicus Hendrik Tilanus. ${ }^{10}$

"Leven zonder te werken, dat kan ik niet. Dan heb ik liever dat God mil roept", sprak Ruys vlak voor zijn dood op vrijdagavond 17 april 1936.

Een onafzienbaar lange rouwstoet van ministers, oud-ministers, kamerleden, burgerlijke en kerkelijke autoriteiten, vertegenwoordigers van politieke partijen en maatschappelijke en culturele instellingen, alsook van gewone stervelingen, begeleidt hem dinsciag 21 april op zljn laatste gang van 't Suideras naar de St. Willibrorduskerk met het bijliggende familiegraf in Vierakker.

Een nationale figuur heeft zijn welverdiende eerbetoon.

\subsection{Betekenis van Ruys}

"Kritiek is den heer Ruij]s de Beerenbrouck niet gespaard, vooral niet in de derde periode van zijn bewind. Ook wij zijn vele malen tegen hem in het strijdperk getreden. Maar al werd er over zljn staatsmansqualiteiten verschillend geoordeeld, een feit is, dat de heer Ruijs in de elf jaar dat hij het minister-presidentschap bekleedde, en het departement van Binnenlandsche Zaken beheerde, nooit een werkelijk ernstige nederlaag geleden heeft. Dat is een feit van beteekenis, hetwelk niet voorbil gezlen mag worden. Van Ruijs de Beerenbrouck - hij moge het verzoenend vergelijk bijwijlen met een lets te gemakkelijke virtuositeit hebben toegepast - kan gezegd worden dat hil zlịn hooge ambten met groote toewijding en nauwgezette plichtsbetrachting vervuld heeft. Een typische regentenfiguur en een goed Nederlander is heengegaan."

Genuanceerd blikt het Algemeen Handelsblad van 18 april 1936 terug op de gisteren overleden kamervoorzitter. Ruys verschijnt in dit artikel als een typische regent, een goed Nederlander en als een staatsman-met-aantekening.

Regent, Nederlander, staatsman: het zijn deze drie hoedanigheden waar het in Ruys' leven om draait en die dan ook nadere beschouwing vereisen 
om zijn maatschappelijke en staatkundige betekenis op waarde te schatten.

De regent Ruys. Een tegenwoordig wat ongelukkige benaming voor lemand die zich, zoals hij, door idealen gedreven op een breed maatschappelijk, cultureel en politiek terrein beweegt. Die zich inzet voor maatschappijverandering. Die grondlegger is van een aaneenschakeling van organisaties, verenigingen en instellingen met materieel en zedelijk doel: van vakverenigingen tot standsorganisaties, van vroedvrouwenschool tot drankweer op nationaal en internationaal niveau. Die levenslang strijdt voor de uiteindelijke emancipatie van zijn bevolkingsgroep: stuwend èn sturend, zoals een elite betaamt die in zo'n strijd een voortrekkersrol heeft te vervullen.

Adel verplicht, hield de oude Ruys zijn zoon voor. En in deze "... persoon - als in die van zijn vader Gustave - [wordt] wel zeer duidelijk gedemonstreerd, hoeveel natuurlijker de adel [soms] tot begrip en waardering van de sociale actie kwam dan de bourgeoisie ...", zeggen we de Nijmeegse historicus prof. L.J. Rogier na. "

De Nederlander Ruys. "Al was hij dan Limburger en katholiek", schrijft Fasseur ${ }^{12}$, "hij maakte een gunstige indruk [op haar]".

Wilhelmina is niet de enige die een berg vooroordelen moet overwinnen als in september 1918 voor het eerst een premier met dubbel handicap aantreedt.

Hoe Nederlands is Limburg eigenlijk met zijn Belgische en Duitse verleden? En de katholieken mogen nu wel door Schaepmans strijd in de volle $z$ in des woords deel zijn gaan uitmaken van de Nederlandse natie ${ }^{13}$, maar het is nog de vraag of die ultramontanen als het erop aankomt het nationale belang zwaarder laten wegen dan het woord van de paus.

Het probleem dat hier speelt is dat van de dubbele loyaliteit van de rooms-katholieken: de vraag of hun getrouwheld toch niet in de eerste plaats uitgaat naar "gene zljde van de bergen" ? Schaepman, de katholleke emancipator met de onwankelbare pausentrouw, schrijft in zljn brochure "Een Katholieke Parti]. Proeve van een program" van 1883 echter: "[Wii] willen geen kerkelijke partij zijn. Wat [wij] willen vermijden ... is julst dit: dat [wij] ook op staatkundig gebied als niets anders gelden dan als aanhangers van het Roomsche geloof ..." 14

Dezelfde gedachte ligt ten grondslag aan Ruys' heftige verzet tegen het plan om de aartsbisschop van Utrecht tijdens de Katholiekendag van 1922 als pleitbezorger voor de staatspartij te laten optreden. Non tall auxilio: de partij mag zich niet met de hulp van de kerk staande zien te houden, 
zomin als zij zich door Rome of Utrecht de wet mag laten voorschrijven. Zo is de anti-SDAP-resolutie van 1922 voor Ruys en Nolens een politieke positiebepaling van de RKSP, derhalve van geen andere - polariserende orde dan bijvoorbeeld de anti-KVP-resolutie van de PvdA in 1969. Het is alleen de partij, en niet (tevens) het episcopaat, die over intrekking van dat besluit heeft te beslissen, is het standpunt van beide voormannen, die overigens slechts in uiterste noadzaak tot samenwerking met soclalisten te bewegen zijn.

Ruys, trouw dienaar van vorstin en vaderland in onafhankelijkheid van de kerk (van Rome): wat moet een politicus doen of laten om een nòg betere Nederlander te zijn?

De staatsman Ruys. "Het kabinet voert een christelijke politiek in overeenstemming met de beginselen der rechterzijde, die het met beslistheid bellidt en uitvoert, evenwel gematigd optredend." Zo luidt de beginselverklaring die in het regeerprogram van alle kabineten-Ruys voorkomt. Het meest karakteristieke van deze repeterende tekst zit in het slot, waarin de geest van de kabinetsleider het sterkste voelbaar is.

Ruys is een man van consensus, die, zoals Kranenburg zegt, naar overleg streeft, méér dan naar doorzetten van eigen wil; die van goeden wil tegenover $u$ en de uwen is, zoals de premier zelf in 1918 aan Marchant schrijft.

Nolens geldt als de architect van de rechtse coalitie. Maar als in de loop van de jaren twintig de voortzetting van de rechtse samenwerking als gevolg van toenemende onderlinge tegenstellingen steeds meer op de tocht komt te staan, is het in de eerste plaats Ruys die door zijn bekwaamheid tot overleg, zijn bindende vermogen en zijn onverwoestbare optimisme de boel bij elkaar weet te brengen of te houden. Tot schade van het land, zoals de vrijzinnig- en sociaal-democraten beweren ? Och, er bestaat ook nog zolets als het belang van de regeerbaarheid van het land, en zou dan een regeringscombinatie van of met twee partijen dle alleen hetzelfde denken over ontwapening en oppositievoeren ècht een veel aanlokkelijker alternatief ziljn ?! Bovendien is het juist onder het bewind van Ruys dat er met name op het gebied van de arbeidersbescherming, de sociale verzekering, de bedrlifsorganisatie, het handels- en het gemeenterecht en de strafvordering zoveel van de grond is gekomen.

In de regeerperiode van Ruys wordt de basis gelegd voor de staatkundige verankering van het premierschap. Op zijn voordracht verschijnt op 13 september 1918 het meergenoemde koninklijk besluit dat de "tijdelijke" voorzitter van de ministerraad coördinerende bevoegdheid toekent in aangelegenheden van algemeen regeringsbeleid. En vervolgens leidt ook 
het op zijn voorstel in 1922 uit voornoemd besluit geschrapte woord "tijdelijke" tot verdere versterking van de positie van de eerste minister.

Ruys bepaalt de agenda van de wekelijkse ministerraad op dinsdag. Bij punt één is de voorzitter aan het woord, die hot issues aansnijdt, de notulen - niet te onderscheiden van een besluitenlijstje - aan de orde stelt en de sfeer schept voor een correcte en zakelijke vergadering. De agenda nodigt voorts elk kabinetslid uit verslag te doen van de gang en de stand van zaken op zijn ministerie. De voorzitter houdt al die tijd de grote lijn in de gaten, plaatst zo nu en dan een vraag of een opmerking, doch kickt niet op allerlei detailproblemen, waar een beetje vakminister zèlf maar uit moet komen.

Ruys houdt er een natuurlijke, onnadrukkelijke regeerstijl opna: hil geeft het goede voorbeeld, motiveert, geeft de ander de ruimte, maar laat, wars van de strakke hand, die ander soms te veel vrijheid van handelen. Als ministers een zakelijk geschil hebben - de conflicten van Aalberse en Verschuur met De Geer zijn er voorbeelden van -, geeft hij er herhaaldelijk de voorkeur aan de zaak uit te stellen om te zien of zij het samen alsnog eens kunnen worden, bóven zelf meteen een beslissing te nemen. Ook in het parlement laat de premier zaken meer dan eens de vrije loop, waardoor de pachtwet bijvoorbeeld een onnodige nederlaag in de Eerste Kamer lijdt. ${ }^{15}$

Ruys met zijn eigenschappen van hoofd en hart, met zijn prijzenswaardig soepele maar ook wat losse regeerstijl: de eindbalans van deze staatsman kan zijn dat hij zich in het weerbarstige interbellum als een vertrouwenwekkende, integere regeerder en bevorderaar van de sociale rechtsstaat heeft betoond.

En dat is toch niet gering ! 


\section{AFKORTINGEN}

\begin{tabular}{|c|c|c|c|}
\hline ARA & Algemeen Rulksarctilef (Den Haag) & OK\&W & Onderwls, Kunsten en \\
\hline $\mathrm{AR}(\mathrm{P})$ & Anti-Revolutionalre Partij & & Wetenschappen \\
\hline BPA & Battaafsche Petroleum Maatschappi] & PvdA & Partil van de Arbeld \\
\hline $\mathrm{CHU}$ & Christellik-HIstorische Unie & RK & rooms-katholiek(-en) \\
\hline $\mathbf{K B}$ & Koninklik beslult & $\mathrm{RKSP}$ & Rooms-Katholleke Staatsparti] \\
\hline KDC & $\begin{array}{l}\text { Kathollek Documentatle Centrum } \\
\text { (Nijmegen) }\end{array}$ & SDAP & $\begin{array}{l}\text { Sociaal-Democratische } \\
\text { Arbeiderspartil] }\end{array}$ \\
\hline KNP & Katholieke Volkspartij & SGP & Staatkundig Gereformeerde Parti \\
\hline NRC-H & NRC Handelsblad & $\mathrm{SHCL}$ & Soclaal Historisch Centrum voor \\
\hline NW & Nederlands Verbond vain & & Limburg (Maastricht) \\
\hline & Vakverenlgingen & VDB & Vrijzinnig-Democratische Bond \\
\hline
\end{tabular}

\section{LITERATUUR EN ARCHIEFBRONNEN}

Andeweg. R.B. (red.), Ministers en Ministerraad. Den Haag 1990.

Bank, J. en Vos, C., Hendrikus Collijn. Antirevolutionair. Houten 1987.

Banning, W., Karl Marx. Leven, leer en betekenis. Utrecht/Antwerpen 1960.

Berg, J.Th.J. van den, De Minister-President; "Aanjager van Noodzakelijk Beleid". Ministers en Ministerrad, a.w., blz. 97-125.

Bergh, G. van den, Eenheld in Verscheidenheld. Hoe moet ans kiesstelsel worden herzlen? Alphen aan den Rijn 1951.

Bouman, P.J., Revolutie der eenzamen. Spiege/ van een tidperk. Assen/Amsterdam 1976.

Bovend'Eert, P.P.T., De Ministerraad en de betekenis van het Regeringsprogramma. Ministers en Ministerraad, a.w., blz. 43-69.

Brinkel, Th.B.F.M., Bruljn, ]. de en Postma, A. (red.), Het kabinet-Mackay. Opstellen over de eerste christelijke coalitie (1888-1891). Baarn 1990.

Brinkel, Th. B.F.M., De Haagse lente. Het kabinet-Mackay, a.w., blz. 42-58.

Buys, I. Th., de Grondwet. Toellichting en kritiek. DI. I. Arnhem 1883.

Charité, J. (red.), Blografisch Woordenboek wan Nederland. DI. I. Den Haag 1979.

Churchil/s memolres over de Tweede Wereldoorlog. DI. II, Amsterdam/Brussel 1963.

Cornelissen, I., Het kalonialisme. De tackle rooje rakkers, een documentaire over het socia/lsme tussen de wereldoorlogen, blx. 125-147, Utrecht 1965.

Comelissen, 1., Tegen het fascisme. De taaie roole rakkers, a.w., blz. 148-173.

Cornips, J., De "Soclale" Ruijs. De Nieuwe Mens. Maandblad voor beleving van her Christendom, Jrg. 4 (1953), nr. 12, blz. 366-374.

Derks, M., Marla wan Nispen tot Sevenaer-Ruys de Beerenbrouck, Roomse dochters, bl2. 13-48. Baarn 1992.

Donner, A.M. , Bestuursrecht. DI. I, Zwolle 1953.

Dorhout Mees, T.J., Kort begrip van het Nederlands Handelsrecht. Haarlem 1956.

Elzinga, D.J., Het Nederlandse kiesrecht, Zwolle 1989.

Fasseur, C., Whetmina. De Jonge koningin. Meppell 1998.

Fortanler, G.F. en Veraart, J.I.M. Arbeidsrecht, Haarlem 1965. 
Giebels, L.J., Beel, van vazal tot onderkoning: blografe 1902-1977. Den Haag 1996.

Gosses, I.H. en Japlikse. N. Handboek tot de Staatkundige Geschiedenis van Nederland. Bewerkt door R. Post en N. Japikse; Den Haag 1947.

Gribling, J.P., P.J.M. Aalberse, 1871-1948. Utrecht 1961.

Gribling, J.P., Willem Hubert Nolens, 1860-1931. Assen 1978.

Harmsen, G., De strijd om het bestaan. De taale roole rakkers, a.w., blz, 41-74.

Hasselt, W.I.C. van, Verzameling van Nedenandse staatsregelingen en grondwetten. Alphen aan den Rljin 1987.

Heringa, A.W. en Zwart, T., Grondwet 1983. Zwolle 1991.

Hoeven. J. van der, Statsrecht en bestuursrecht. Zwolle 1984.

Jong. L. de, Het koninksijk der Nederlanden in de Tweede Wereldoorlog. DI. I. Den Haag 1969. Katholleke Illustratie. In memoriam Z. Exc. Jhr. mr. Charles Rurys de Beeren-

brouck. Extra nr. (april 1936).

Keynes, J.M.. Economic Possibillities for our Grandchildren. In: Ch. Handy, De toekomst van de arbeid, blz. 29-30. Utrecht/Aartselaar 1986.

Kimman, E.J.J.M., De arbeldswet van minister Ruys van Beerenbroek. Het kabinet-Mackay, a.w., blz. 169-190.

Kortmann, C.A.J.M., De Grondwetsherzlening 1983. Deventer 1983.

Kranenburg. R., Inleiding in het Nederland's administratiefrecht. Bewerkt door W.G. Vegting, Haarlem 1955.

Kranenburg, R., Het Nederland's staatsrecht. Haarlem 1958.

Krol, Ch.B., A/s de Koning dit eens wist...l. Antwerpen 1994.

Kuiper, D.Th., Na honderd jaar: verandering of continuitelt. Het kabinet-Mackay, a.w., blz. 250-262.

Lubbers, R.F.M., Rul|s de Beerenbrouck. Erflaters van de twintigste eeuw, blz. 210-230, Amsterdam 1991.

Lubbers, R.F.M., Geloof in de samenleving. Christen-democratie in drie generaties: Ruils, Klompe, Lubbers. Nijmegen 1998.

Meljers, E.M., Erfrecht. Bewerkt door P.W. van der Ploeg en A.G. Solinge, Zwolle 1976.

Minkenhof, A. De Nederland'se strafvordering. Haarlem 1948.

Niezen, I. (hfd. red.). Kronjek van 100/aar Oympische Spelen 1896-1996. Amsterdam 1995.

Nispen tot Sevenaer, Jhr. C.M.O. van, Balans van ruim 25 jaar pachtrecht.. In: J. van Andel e.a. (red.) Pacht en grondgebruik, Deventer/Antwerpen 1964.

Oud, P.J., Honderd laren. Assen 1961.

Oud, P.J.. Het constitutioneel recht van het Koninkrlik der Nederlanden. Zwolle 1967.

Oud, P.J., Het jongste verleden. Parlementalre geschiedenis van Nederland 1918-1940. DI. l-Vl, Assen 1968.

Oud, P.J. en Bosmans, I., Staatkundige vormgeving in Nederland. DI. I-II. Asser/Maastricht 1990.

Peters, J.A.J., Edelman-Volksman. De Nieuwe Mens, a.w., blz. 353-355.

Pitlo, A. Het erfrecht naar het Nederlands Burgerlijk Wetboek. Haarlem 1957.

Pitlo. A., Het verbintenissenrecht naar het Nederlands Burgerlik Wetboek, DI. Il. Groningen 1974.

Pot, C.W. van der, Handboek van het Nederlandse staatsrecht. Zwolle 1962.

Pot, C.W. van der en Donner, A.M., Handboek van het Nederlandse staatsrecht. Bewerkt door L. Prakke, J.L. de Reede en G.J.M. van WIssen, Zwolle 1995. 
Puchinger, $\mathrm{G}_{\text {. }}$ Collfn en het elnde vain de coaltte. I. De geschiedenis wan de kabinetsformatles 1918-1924; II. De geschledenis van de kabinetsformaties 1925-1929. Kampen 1970-1980.

Puchinger, G., Ontmoetingen met Nederlandse politici. Zutphen 1981.

Puchlinger, $G_{4}$, Nederlandse Minister-Presidenten van de twintigste eeuw. Amsterdam 1984.

Raalte, E. van, Het Nederlandse Parfement. $2^{\text {th }}$ druk, Den Haag 1960.

Raalte, E. van, Het Nederlandse Parlement. $7^{\text {de }}$ druk, bewerkt door P.P.T. Bovend'Eert en H.R.B.M. Kummeling, Den Haag 1991.

Raalte, E. van, Enige herinneringen aan Jhr.mr. Ch.J.M. Ruys de Beerenbrouck. Tifdschrift voor Overheldsadministratle, j.g. 30 (1974), $\mathrm{nr} .3$, blz. 11-15.

Rerum Novarum, encycliek van paus Leo XIII van 15 Mel 189 I over de toestand der arbelders. Hilversum 1955.

Rogler , L.J. en Rooy, N. de, In vrijheld herboren. Kathollek Nederland' 1853-1953. Den Haag 1953.

Romein, I. en A., Erflaters van onze beschaving. Nederlandse gestalten uit zes eeuwen. Amsterdam 1977.

Rood, M.G., Introductie in het soclaal recht. Deventer 1998.

Scheffer, H.J., November 1918. Joumaal van een revolutle die nlet doorging. Utrecht 1984.

Schenk, M.G. Een Eeuw Vorstinnen. Honderd Jaar vrouwen op de Nederlandse troon. Amsterdam $\$ 989$.

Schurgers, H.J.H., Charles Ruys: mens, christen, staatsman. Valkenburg 1973.

Spanning, $H$. wan, De Christellik-Historische Unie (1908-1980). Enige hoofdlinen uit haar geschledenis. DI. I-II. z.p. 1988.

Streek, H. van de, Het vrouwenkiesrecht als ideologische breuk? ARP. CHU en RKSP in het Interbellum. Splegel Historlael, Irg. 27 (1992), nr. 6, blz. 225-230.

Strolnk, F.A.M. en Steenbeek, J.G., Inlelding in het staats-en bestuursrecht. Alphen aan den Rujn 1993.

Tolrkens, S.J., De Minlster van Financlën; In het spanningsveld van financiële wensen en mogelljkheden. Ministers en Ministerraad, a.w., blz. 127-146.

Vegting, W.G. Her algemeen Nederland's administratiefrecht. DI. II, Alphen aan den Rijn 1957.

Vellenga, S.Y.A., Kathollek Zuid-Limburg en het fascisme. Een onderzoek naar het kiesgedrag wath de Limburger in de jaren dertig. Assen 1975.

Verhagen, I.A.H., De totstandkoming van het eerste ministerle Ruifs de Beerenbrouck. Den Bosch 1952.

Verhagen, J.A.H., Een kathollek staatsman. De Neunve Mens, a.w., blz. 375-378.

Vermeulen, $\mathrm{H}$., De Maasbode. De bewogen geschiedenis van "De beste courant van Nederland". Zwolle 1994.

Wareham, $\prod_{*}$, Proffe/schetsen wan managers. Utrecht 1988.

Wleland, J.H.M. e.a. (red.), De gouverneurs in de belde Limburgen 1815-1989. (ultgave van het

Limburgs Geschled- en Oudheldkundig Genootschap, dl. Xl) Maastricht 1989.

Wijnen. H.A. van "Van de macht des konings. Amsterdam 1975.

WIInen, H.A. van, Koningschap maakt politlek nerveus. NRC Handelsblad van 16-10-1996.

Wi|nen, IH.A. van, De pers en het geheim van Noordeinde. NRC Handelsbladvan 13-021997.

Wilhelmina "Eenzaam maar niet alleen. Amsterdam 1959. 


\section{ARA}

"archief van fhr.mr. Ch.J.M. Ruys de Beerenbrouck" (Toestemming tot raadpleging archlefRuys verleend op 02-12-1997. In het KDC bevindt zich een filmkople van het ARA-bestand van Ruys).

\section{KDC}

archief Nolens

archief Aalberse

archief RKSP

\section{SHCL}

Ruys varia.

\section{NOTEN}

\section{WOORD VOORAF}

1. Oud/Bosmans, Staatkundige vormgewing 1 , blz. 306-310, bevat een overzicht van blografieën enz. van politicl uit dle tljd.

2. BankNos, Hendrikus Collin, blz. 6-7.

3. Korte biografieën van Ruys in: Puchinger, Ontmoetingen met Nederlandse pollticl, blz. 93-1 12; Schurgers, Charles Ruys; maandblad De Nieuwe Mens, maart 1953;

Van Raalte, "Enige herinneringen aan $\mid \mathrm{hr}$. mr. Ch. J. M. Ruys de Beerenbrouck"; De Katholieke IIlustratle, In memoriam, aprll 1936 ; Lubbers, Geloof in de samenleving, bly. $11-43$.

4. Verzameling korte blografleèn in Erfaters van de twintigste eeuw, blz. 210-230.

5. Puchinger, a.w., blz. 112

6. In de 56 gemeenten die Limburg per I januari 1995 kende is - afgezlen van de royalty - de voormalige hoofdaalmoezenler en promotor van de katholieke arbelders(-beweging), dr. H.A. Poels ( $1868-1948)$, met 38 naar hem vernoemde straten koploper op eerbledige afstand gevolgd door politicl van landelijke betekenis als Nolens (117x), Schaepman $(11 x)$, Charles Ruys $(9 x)$, Thorbecke $(8 x)$, Kuyper $(5 x)$ en de "Vader des Vaderlands", Willem Drees ( $\| x$, maar hil was toen ook pas 7 jaar geleden overleden ...).

\section{HOOFDSTUK 1}

1. Zo wordt in afwijking van de voorstellen van de commissle-Thorbecke de Eerste Kamer nlet rechtstreeks gekozen, maar volgens getrapte verkjezing door de Provinclale Staten. Voorts wordt de voorgestelde algehele vrijheid van openbare godsdienstoefening beperkt tot plechtigheden binnen gebouwen en besloten plaatsen; buiten die lacaties blifft 
echter het principe van onvrilheld gehandhaafd, met uitzondering van gemeenten waar wulke "kerkellike optochten" volgens de in 1848 bestalande toestand zijn toegelaten. Ook het onderwijsartikel van de commissle haalt het niet. Op de onderwilskwestie wordt hierna in onderdeel 1.4 verder ingegaan.

2. Oud/Bosmans, Statkundige varmgeving I, blz. 21.

3. Van der Pot/Donner, Staatsrecht, blz, 146-147, met de aldaar aangehaalde werken van Oud en Van der Hoeven ; Stroink/Steenbeek, In/elding staats-en bestuursrecht, blz. 16-17.

4. Toen de eerste vrouwelijke arts in Nederland, de feministe Aletta Jacobs, zich in 1883 als behorende tot "ingezetenen, tevens Nederlanders of door de wet als Nederlandse onderdanen erkend", in Aunsterdam op de klezerslijst wilde laten plaatsen, werd haar dat als in strijd met de geest van de grondwet geweigerd. Bil de grondwetsherziening van 1887 werd "mannelijke" vóór "ingezetenen" Ingevoegd en werden alzo de tijdgeest en de letter van de wet weer - even - in overeenstemming met elkaar gebracht.

5. Oud/Bosmans, a.w., blz. 77.

6. Van der Pot/Donner, a.w., blz. 110 ; Stroink/Steenbeek, a.w., blz. 86.

7. Oud, Het jongste verleden I, blz. 10.

8. Oud/Bosmans, a.w., blz. 109.

9. Ibld., blz. 109.

10. Rogler/De Rooy, In writheld herboren, blz. 362-363.

11. Vermeulen, De Maasbode, blz. II0.

112. Van Spanning, De Christelik-Historische Unie, Het ontstaan, blz. 1-56.

13. "Zij" [de katholieken], sprak Schaepman, "willen geen kerkellike partij ziljn. Wat zij willen vermijden wat zl| voor de toekomst onmogelij] willen maken is Juist dit: dat zil ook op staatkundlg gebled als niets anders gelden dan als aanhangers van het Roomsche geloof. Daarom willen zilj een staatkundig program ..." (Herdenkingsnummer van de Katholleke Illustratle).

14. Rogler/De Rooy, a.w., blz. 450.

15. Oud/Bosmans, a.w., blz. 185.

16. Door het leger In te schakelen en een stakingsverbod voor werknemers bij de openbare nutsbedrilven af te kondigen had Kuyper een eind gemaakt aan een in 1903 onder het spoonwegpersoneel uitgebroken staking. Toen hil vervolgens de staking in de troonrede ook nog als een "misdadige woeling" liet brandmerken, kwam hij op voet van oorlog te staan met de soclalisten en de linkse vakbonden.

17. Oud/Bosmans, a, w., blz. 212.

18. FortanierNeraart, Arbeldsrecht, biz, $14-15$.

19. Puchinger, Ontmoelingen met Nederlandse polftict. blz. 67.

20. Stroink/Steenbeek. A.w., blz. 78 .

\section{HoOFDstuK 2}

1. Rogler/De Rooy, In writheld herboren, biz. 348.

2. Puchinger. Collin en het elnde wan de contlite: biz. 40 .

3. Bbid. ble, 44.

4. $\mathrm{KDC}_{+}$archief Nolens.

5. Puchinger, a., $w_{r}$ blz. 39-40.

6. Puchenger, a.w., biz. 47.

7. $\mathrm{KDC}_{\text {, archler Nolens. }}$

8. Gribling, Nolens, biz. 190 . 
9. Puchinger, a.w, blz. 107.

10. Puchinger, a.w., blz. 48 ; Oud, Het fongste werleden 1 , blz. 61 .

11. Puchinger, a. $w_{*, i}$ blz. 80.

12. Gribling, Aaberse, blz. 305 .

13. Gribling, ibid., buz. 523.

114. Puchinger, a.w., blz. 137-138.

15. Verhagen, De totstandkoming van het eerste ministerte Ruys de Beerenbrouck, stelling 1 .

16. Oud, a.w., blz, 62-63.

17. Puchinger, a.w., blz. 130.

18. Gribling, Nolens, blz. 200.

19. Puchinger, a.w., blz. 159.

\section{HOOFDSTUK 3}

1. ARA archlef Ruys, waaraan zijn toegevoegd een levensbericht door mr. Pla LokinSassen en een korte familiegeschiedenis door $\mathrm{hr}$, mr. C.C.C.M. van Nispen tot Sevenaer.

2. Ruys of Ruijs ? In verband met de plannen tot oprichting van een gedenkteken ter ere van de oud-premier, stelde het Rj|ksarchief in Maastricht een onderzoek in naar de juiste schrijfwijze van de familienaam. In een Ingezonden stuk in het dagblad De Tyd van 16 november 1961 vermeldt hoofdlarchivist M.K.J. Smeets als resultaat van zilin onderzoek dat de rechtbank-Roermond in 1895 de famllienaam in Ruljs, enz. veranderde, hoewel zll in haar vonnis refereerde aan een KB van 25 jull 1825 (Stbl. nr. 6.1). waarbij werd goedgekeurd de eerste lijst van personen of geslachten die zi|n ingeschreven in de registers van den Hoogen Raad van Adel. Op die lifst is de schrlifwiljze echter: Ruys. Of de staatsman die laatste schrljfwijze zelf steeds heeft gevolgd valt moeilijk na te gaan, al wi|zen officiële staatsdocumenten wel in die richting. Op het gedenkteken in Maastricht komt ziljn naam met een "lange If" voor, op de gedenkplaat :" tegen de gevel van zi|jn geboortehuls in Roermond daarentegen met een "Grlekse y". In dit werk wordt de Grieks-Franse schrljfwl|ze aangehouden.

3. Kimman, "De arbeldswet van minister Ruys van Beerenbroek", blz. 169-190.

4. Aalberse over Ruys in het herdenkingsnummer van de Katholieke lliustratie.

5. Gribling, Aalberse, blz. 43.

6. Ruys als drankbestrijder in het herdenkingsnummer van de Katholieke lliustratle.

7. Als het Ruys ulteindelljk lukt in bestekken van de gemeente bepallngen op te nemen over maximale arbeldsduur en minlmumioon, moet de wethouder van Openbare Werken even ziln frustraties luchten over de zoveelste "Inbreuk op de vrijheld en de rechten der werkgevers" (vgl. I. Cornips, "De "Sociale" Ruijs", blz. 366-374).

8. Derks, Roomse dochters, blz. 16. Tekenend voor de roomse gezincheld van de famille is de bedankbrlef van Ruys voor de gelukwens die hlj ter gelegenheld van het huwelik van ziln zoon, op 10 mel 1931 namens de paws van kardinaal Pacelll - de latere Plus XII - ontving: "II m"est difficile d'exprimer à Votre Eminence Réverendissime l'émotion profonde qu'a suscitée dans mon coeur de père la bénédiction apostollque et les voeux paternels, que le Saint Père a daigné envoyer à l"occaslon du marlage de mon fils Gustave." (ARAKDC, archlef Ruys).

9. Rijksarchlef Maastricht.

10. Kasteel Wolfrath met Ianderijen gaat blikens het Kadaster in dienstjaar 1906 bil successie over op \$hr. mr. G.L.M.H. Ruys de Beerenbrouck, CdK in Limburg: na diens overlij- 
den in 1926 op fhr. mr. Ch.l.M. Rusys de Beerenbrouck, Minister van Statat en voorzitter van de Tweede Kamer, wonende Laan Copes van Cattenburg. 27 in Den Haag: vervolgens in 1937 op de laatste kasteelheer, fhr. mr. G.AM.J. Ruys de Beerenbrouck, die in 1983 overlijdt. Grootvader en kleinzoon met hun resp. echtgenotes liggen begraven bli] de kerk in Holtum, gemeente Born.

\section{HOOFDSTUK 4}

1. Het op voordracht van Ruys totstandgekomen $\mathrm{KB}$ van 13 september 1918 , nr. 38 , heeft tot doel een eind te maken aan coördinatieproblemen, zoals die zich o.a. begin 1918 voordeden, toen twee ministers uit het kabinet-Cort van der Linden in de kamer tegenstrijdige beleidsvoornemens verdedigden.

2. Gribling, Nolens, blz. 185.

3. KDC, dagboek Aalberse V1 09-08-1918; ARAKDC, archlef Ruys.

4. De encycllek van paus Leo XIII geeft de aanzet tot een katholiek-sociale politiek. Op de kerk, de staat en de gezamenlijke klassen van werkgevers en werknemers rust de taak om de sociale kwestie te regelen. De encycliek wilst het socialisme als oplossing voor het verbeteren van de sociaal-economische omstandigheden van de hand en roept de katholleke arbeiders op zich in katholleke organisaties te verenigen om hun belangen te behartigen.

5. Handelingen Tweede Kamer 1918-1919, blz. 259 e.v.

6. Scheffer, November 1918, blz. 68.

7. Ibid., blz. 87; Oud, Het jongste verleden I, blz. 84.

8. Scheffer, a.w. blz. 99-103.

9. Handelingen Tweede Kamer 1918-1919, blz. 331 e.v.

10. Ibid., biz. 341 -349.

11. KDC, dagboek Aalberse VI 12-11-1918.

12. Puchinger, Collifn en thet einde van de coalitie I, blz. $\| 75-176$.

13. Handellingen Tweede Kamer 1918-1919, blz. 371 e.v.

14. Scheffer, a.w., blz, 141 .

15. Handelingen Tweede Kamer 1918-1919, blz. 376 e.v.

16. lbid.

17. Ibid., blz. 400 e.v.

18. Ibid., blz. 468 e.v.

19. Grlbling, Aatberse, blz. 523; ARA/KDC, archief Ruys.

20. Oud, a.w. blz. 93 .

21. Hillie van de Streek, "Het wrouwenklesrecht als ideologische breuk ?", blz, 225.

22. Scheffer, a.w., blz. 212.

23. de Wolkskrant van 07-12-1996.

24. Scheffer, a.w., blz. $224 ;$ Oud, a.w., blz. 101-102.

25. Statscourant 20-11-1918, nr. 272A: ARAVDC, archief Ruys.

26. Handelingen Tweede Kamer 1979.1980, 16036 (R 1139), nr. 3, blz. 3.

27. In de parlementaire praktijk komt het overigens regelmatig voor dat de premier op verzoek van de kamer(s) zelf rekening en verantwoording voor het regeringsbeleid komt afleggen, dan wel zelf het onaanvaardbaar komt uitspreken over een "dwarse" opstelling van de Tweede of Eerste Kamer. Voorts is de positie van de ministerpresident versterkt door internationale ontwlkkelingen die meebrengen dat principlële beslutten in de Europese Gemeenschap nlet llanger worden genomen door de EGministerraad (de ministers van buitenlandse zaken), maar door de Europese Raad van 
staatshoofden c.q. regerings- en kabinetsleiders (vgl. Van der Pot-Donner. blz. 391 en 1. van den Berg: "De Minister-President", biz. 114). In dit verband ook A.W. Heringa" "...je zou veronderstellen dat het hele Nederlandse staatsbestel aan de grondwet ontspruit. Wat mili verbaasde was dat dat op een aantal essentiële onderdelen nlet zo blijkt te zilin ... voor een deel is de wetgever ook onderworpen aan besluitvorming ult Brussel." in $N R C-H$ van 12-03-1998.

28. Scheffer, a.w., blz. 140.

29. KDC, dagboek Aalberse VII 13-11-1918.

30. Vgl. voetnoot 24.

31. Oud, Het constitutioneel recht 1, blz. 195.

32. Van der Pot, Staatsrecht, blz. 57.

33. Oud, Het fongste verleden I, blz. 380.

34. Banning, Karl Marx, blz. 79.

35. Handelingen Tweede Kamer 1918-1919, blz. 660 e.v.

36. Gribling, Aatberse, blz. 354.

37. Oud, Het jongste verleden I, blz. 121.

38. Harmsen, "De strild om het bestaan", blz. 41.

39. In totaal zijn in de jaren 1919-1925 275.027 woningen met medewerking van het ministerie van arbeld gebouwd. Tevens is in dle periode een bedrag van ruim $1 / 2$ millard uitgekeerd aan bouwwoorschotten en -bijdragen (vgl. Gribling, Aalberse, blz. 356).

40. Rede van Kuyper bil de opening van de Vrije Universiteit op 20-10-1880.

41. Rogier/De Rooy, In vrijheid herboren, blz. 473.

42. Dat was de intentle van de "eerlijk makelaar" tussen rechts en links, Cort van der Linden, uitgesproken tijdens het algemene begrotingsdebat in 1913.

43. Oud, Het jongste verledien I, blz. 110.

44. Puchinger, a.w. blz. 142.

45. KDC, dagboek Aalberse VI 25-09-1918.

46. Oud, Het jongste verleden I, blz. 223.

47. Puchinger, Nederlandse politicl, blz. 162.

48. KDC, archief Nolens 662.

49. Wareham, Profielschetsen van managers, blz. 177.

50. Puchinger, Nederlandse politici, blz. 103: "Soms wees hil] [Ruys] In zl]n departementskamer op het portret van Thorbecke en zei: "zoo geleerd alls diëen ben lk niet". Over Nolens zou Ruys hetzelfde kunnen zeggen.

51. De jong, Koninkrijk der Nederlanden In de $2^{\text {de }}$ Wereldoorlog II, blz. 56-58.

52. Gribling, Aalberse, blz. 378 .

53. Idenburg wordt opgevalgd door de partjloze De Graaff, die in alle drie de kabinettenRuys kolonlën beheert.

54. Puchinger, Collin en het elnde van de coalitie 1 , blz. 185-186.

55. KDC, dagboek Aalberse VII 26-03-1920.

56. Ibld., Vill 15-01-1921.

57. Puchinger. Colijn en het elnde van de coalitie I, blx. 173.

58. Oud, Het jongste verleden I, blz. 284 .

59. Ibld.

60. Van der Pot/Donner, Staatsrecht, blz. $381-382$.

61. Van Raalte, Het Nederlandse parlement, $2^{\text {de }}$ druk, blz. 26-28.

62. ARA/KDC, archief Ruys.

63. Ibid.

64. Puchinger. Colifn en het einde van de coalitie 1, blz. 199. 
65. Gribling, Nolens, biz, 219.

66. De Jong, a.w., blz. 58 .

67. Ibid.

68. Oud, Het jongste verleden 1, blz. 312 .

69. Ibid, biz. $321-322$.

70. Leden van de staatscommissie zijn: de Tweede-Kamerleden mr. D.J. de Geer (CHU) en J.H.A. Schaper (SDAP), Eerste-Kamerlid mr. I. Kappeyne van de Coppello Jr. (lib.), staltsraad dr. A.A.H. Struycken (RK), prof. mr. A. Anema (AR) en mr. I. Limburg (NDB), lid G.S. Zuid-Holland.

71. In afwijking van het rapport van de staatscommissie bepaalt grondwetsartikel 61 van het regeringsontwerp dat de regelingsbevoegdheid van de Kroon inzake inwendige aangelegenheden van de overzeese gebieden steun moet vinden in een wet. Aan het door de staatscommissle voorgestelde ontelgeningsartikel voegt het regeringsontwerp toe: "... dan na voorafgaande verklaring bil, de wet, dat het algemeen nut onteigening vordert ...". Ook neemt de regering de drie navolgende en nader aan de orde komende voorstellen van de staatscommissle nlet over: het referendum over de statsworm. de niet-verplichte adviesaanvraag aan de Raad van State over wetsontwerpen, alsmede - In tweede instantie - de samenstelling van de Eerste Kamer.

72. Van Raalte, Het Nederlandse parlement, $7^{\text {te }}$ druk, blz. 293-294.

73. Oud, Het Jongste verledlen I, blz. 358.

74. Ibid., blz. 328 .

75. Ibld.

76. De Eerste Kamer had zich overigens tijdens en na de revolutlonalire novemberweek van 1918 nauwelijks laten horen. (vgl. Handelingen Eerste Karner 1918-1919, blz. 15 e.v.)

77. Van der Pot/Donner, a.w., blz. 402.

78. Vgl. hiervóór, blz. 16.

79. Drie leden van de staatscommissile - statatsraad Struycken, Schaper en Limburg - stonden op het standpunt dat het horen van de Raad van State over wetsontwerpen diende te vervallen om plaats te maken voor een door een gedemocratiseerde Eerste Kamer te verrichten toetsing van alle wetsontwerpen aan de volksovertuiging. Om de patstelling in de commissle te doorbreken, stelde Ruys voor dat het de regering wel zou moeten vrijstaan de Raad over wetsvoorstellen te horen. Het voorstel van de voorzitter wordt met 4 tegen 2 (Struycken en Kappeyne) stemmen aangenomen en vervolgens te licht bevonden in de ministerraad van 28 april 1919. (ARA/KDC, archief Ruys).

80. Van Raalte, Het Nederlandse parlement, $2^{\text {de }}$ druk, blz. 79.

81. Oud, Het jongste verleden I, blz. 384.

82. "De behandeling der Grondwet .... is voor Charles geen succes geweest, ofschoon deze - wellicht gelukkig - 't zelf niet Inziet. Neen, in de schatting der intellectuelen hebben we geen mool figuur gemaakt, en dat is wel jammer van 't eerste kabinet van katholleke signatuur ..." "moet partljvoorzitter Van Wijnbergen even kwijt aan Van Nispen. "Ik hoop dat Antoine [v.W.] in stat zal zijn rustig en onbevangen het geheel te overzien. Ziln optreden in de laatste faren heeft hem niet het algemeen vertrouwen doen kiligen.", zo praat de gehekelde wetgever de Nederlandse gezant bil het Vaticaan weer helemaal bil) (vgl. Puchinger, Collin en her einde van de coalihte I, blz. 234).

83. Van Raalte, Het Nederlandse parlement, $2^{\text {* }}$ druk, blz. 80-81.

84. Voormalig voorzitter van de Eerste Kamer, mr. H.D. Tjeenk Willink, in NRC-H van 2501-1997.

85. ARA/KDC, archlef Ruys.

86. Fasseur, Withelmina, blz. 541 . 
87. Vgll. voetn. 82 .

\section{HOOFDSTUK 5}

1. Naast Suze Groeneweg (SDAP) was in 1921 een tweede vrouw, Johanna Westerman (lib.), tussentlijds in de kamer gekomen.

2. KDC, dagboek Aalberse VIII 18-07-1922.

3. $\mathrm{KDC}$, archief Nolens.

4. Gribling, Aaberse, blz. 391 .

5. Puchinger, Colijn en het einde van de coalitie I, blz. 229.

6. KDC, dagboek Aalberse VIII 18-07-1922.

7. Van der Pot/Donner. Staatsrecht, stelregels en spelregels in de Nederlandse polltlek, biz. 146-149.

8. ARA/KDC, archief Ruys.

9. Puchinger, a.w., blz. 256.

10. KDC, archief Nolens.

11. Ibid.

12. Ibid.

13. Oud/Bosmans, Statkundige vormgeving l, blz. 94 .

14. Wilhelmina, Eenzaam maar niet alleen, blz, 154.

15. Gribling. Nolens, blz. 168-176.

16. ARAVKDC, archief Ruys.

17. Ibid.

18. Ibid.

19. Bovend'Eert, "De Ministerraad en de betekenis van het Regeringsprogramma", blz. 4348.

20. In het antwoord dat Ruys op 15 augustus van de CHU-fractie ontving over de vlootkwestle, was geen melding gemaakt van het felt dat De Geer zich daarmee niet kon verenigen. (Puchinger, a.w.. blz. 274).

\section{HOOFDSTUK 6}

1. Oud, Het constitutioneel recht I, blz. 270; Van der Pot, Staatsrecht, blz. 222. In deze zin ook premler Van Agt, die bij het aantreden wan zijn eerste kabinet in 1977 in de Tweede Kamer verklaarde dat de ministers eerst na hun beëdiging staatsrechtelljk bevoegd ziln regeringsdaden te verrichten.

2. Puchinger, Colijn en het einde van de coalitie I, blz. 305-306.

3. Ibld, blz. 307.

4. $\|$ bid., blz. 306.

5. Oud, Het jongste verleden II, blz, 46 .

6. Puchinger, a.w., blz. 307.

7. KDC, dagboek Aalberse VIII 07-02-1923.

8. ARAKDC, archlef Ruys.

9. Ibid.

10. Ibid.

11. Huizinga, Heemskerk Azn, (1818-1897). Conserwatlef zonder partl).

12. ARAKDC, archief Ruys.

13. Fasseur, W/he/mina, blz. 362 en 371 . 
14. Pitio, Erfrecht, blz. 31.

15. Minkenhof, De Nederlandse stratwordering, biz. 8-12.

16. Gribling, Aalberse, blz. 403.

117. $\mathrm{KDC}_{n}$ dagboek Aalberse $\mathrm{X}$ 07-05-1923.

18. FortanlerNeraart, Arbeldsrecht, blz, 18.

19. De mening van Struycken over het kiesstelsel in Oud, Het fongste verleden III, blz. 12. Deze "buitengewoon moeillike materle" is het werk van de latere hoogleraar staatsrecht aan de Universiteit van Amsterdam, G. van den Bergh.

20. Stroink/Steenbeek, Inleiding in het staats-en bestwursrecht" blz. 89 .

21. ARAKDC, archief Ruys.

22. Toirkens, "De Minister van Financiën", blz. 134-135; Puchinger, a.w., blz. 257.

23. Puchinger, a.w., bliz. 335.

24. Ibld., blz. 428.

25. KDC, dagboek Aalberse $1 X$ 01 - 10-1923.

26. Puchinger, a.w., blz. 406-407.

27. Oud, Het jongste verleden II, blz. 117.

28. Puchinger, a.w., blz. 450-451.

29. Vgl. hlervóór biz. 72.

30. Oud, Het jongste verleden II, blz. 24.

31. Grlbling, Nolens, blz. 235.

32. Handelingen Tweede Kamer 1923-1924, blz. 138 e.w.

33. Ibld., blz. 189 e.v.

34. Ibid.

35. Gribling, Aabberse, blz. 413.

36. Handelingen Tweede Kamer 1923-1924, blz. 231 e.v.

37. Oud, Het jongste verleden II, blz. 137.

38. Puchinger, a.w., biz. 459.

39. Ibid., biz. 458-460; ARAKDC, archief Ruys.

40. Nog afgezien van het feit dat niet de hele RK fractie, doch slechts een minderheid zich tegen de vlootwet keerde, is het de vraag of hier sprake is van schending van coalitieafspraken. Ook al zouden over de vlootkwestle duidelijke afspraken zijn gemaakt quod non -, dan nog scheppen, aldus Van der Hoeven in ziln inauguratierede van 1960 aan de Universitelt van Amsterdam, "formele bindingen" tussen de regering en de meerderheldsfracties geen rechtsplicht, zelfs geen morele plicht tot het naleven daarvan. In laatste instantle moet elke kamerlid autonoom bepalen wat het in de gegeven

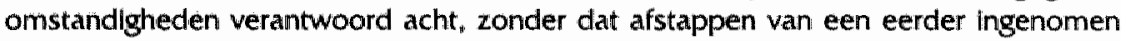
standpunt op zichzelf als "woordbreuk" valt aan te merken. Dikwijls blijkt men ook achter de felten aan te lopen met het formuleren van "specifieke" normen, alls: wie breekt betaalt; het kabinet behoort af te treden bij coalitiebreuk. Ook Van der Pot (a.w. blz. 336) betwiffelt of men thler kan spreken van regels die steeds behoren te worden gevolgd. De praktl|k stoort zlch tenminste niet altijd aan de "norm", zoals o.a. bleek in 1982, toen de BudA de coalitle met het CDA en D66 verbrak en het kabinet-Van Agt II met de steun van de beide overige fractles doorregeerde.

41. Puchinger, a.w., blz. 453; het vers is afkomstig van J.H. de Waal Mallefijt. minister van kolonièn in het kabinet-Th. Heernskerk.

42. Puchinger, a.w., blz. 464.

43. In de fractlevergadering van de AR op 15 januarl 1924 erkent Rutgers dat zijn verwlit aan het adres van de katholleken overtrokken was, omdat het (vloot-)akkoord van 1922 in staatsrechtelljk opzicht een zwak punt is. (vgll. Puchinger, a.w., blz. 577). 
44. KDC, archlef Nolens.

45. Puchinger, a.w, blz, 490 .

46. ARAKDC, archief Ruys.

47. Puchinger, a.w., bli. 507.

48. Nolens had de koningin op 24 november 1923 laten weten: "... de Roomsch. Katholleke Staatspartij in de Tweede Kamer zoo in haar geheel als wat de leden afzonderlijk betreft, [is] nog steeds niet bereid tot samenwerking met de SoclaalDemocratische Arbeiderspartij ..." (ARAKDC, archief Ruys).

49. Van Raalte, Het Nederlandse parlement, $2^{\text {de }}$ druk, blz. 35. De NRC van 25 december merkt in haar commentaar op de formatieopdracht o.m. op ".... dat de eigenlijke regeering van het kabinet op eene kamermeerderheld overgat, die ten slotte aan niemand verantwoordelijk ziljn zal ... Zoo komt alles op z'n kop te staan...".

50. ARAKDC, archief Ruys.

51. Ibid.

52. In de partil heerst een crisissfeer, die zich niet beperkt tot de fractie, maar ook het partijbestuur en de katholleke ministers aanzet tot verwillten over en weer over de vlootkwestie. De parti] is ziek, stelt Ruys vast, en het kjezerskorps zou dat wel eens kunnen afstraffen.

53. KDC, archief Nolens.

54. Puchinger, a.w., blz. 555.

55. ARAKDC, archief Ruys.

56. Handielingen Tweede Kamer 1923-1924, blz. 325 e.v.

57. Oud, Het jongste verleden I, blz. 64.

58. Oud, Het jongste verleden II, blz. 171.

59. Ibld., blz. 170 .

60. Ibld., blz. 160 .

61. Kranenburg/Negting, Inteiding in het Nederlands adiministratiefrecht, blz. 92-93. Anders dan de aldaar genoemde auteurs, leiden o.a. Van der Pot, Donner, Vegting en Van der Grinten uit het specifieke karakter van de ambtenaarsverhouding af dat de ambtenaar een voortdurend recht op het eens vastgestelde salaris niet toekomt.

62. Oud, Het jongste verleden II, biz. 163.

63. Hekeldicht uit de jaren twintig op de VDB.

64. In de verkiezingsstrijd van 1925 wordt door de SDAP met leuzen als: "HII weet de centen te vergaairen. Uit het bloed en zweet der ambtenaren", stevig op de man - CoIljn - gespeeid.

65. "Van oude mensen, de dingen dle voorbllgaan" "roman uit 1906 van Louls Couperus (1863-1923).

66. Kroniek van 100 jaar Oympische Spelen, blz, XII-XIII.

67. Puchinger, a.w. biz. 452.

68. ARAKDC, archief Ruys.

\section{HOOFDSTUK 7}

1. Puchinger, Colijn en het einde van de coalltie II, blz. 10.

2. ARAKDC, archlef Ruys.

3. Vgl. hiervóór blz. 25 en 87 . Kuyper overleed op 8 november 1920 , Lohman op 11 junl 1924.

4. Puchinger, a.w. blz. 380.

5. Handelingen Tweede Kamer 1925-1926, blz. 242. 
6. Ibid.

7. Vermeulen, De Maasbode, blz. 187.

8. Oud. Het fongste venleden II, blz. 37.

9. Puchinger, a.w., biz. 395.

10. Oud. Het jongste verleden I, blz. 40: "Sterk herinnert hil [Marchant] aan een figuur als. de franse staatsman Clemenceau, de "tilger", biltend van sarcasme, een ware "tombeur de ministres ${ }^{\mathrm{kn}} . . . "$.

11. Op 7 mel 1935 deelde minister Marchant de ministerraad mee te zijn overgegaan tot de katholleke kerk. Daags daarna liet partiggenoot, minister Oud, premier Colljn weten te zullen aftreden als Marchant gehandhaafd bleef. Op 13 mel verscheen een perscommuniquét waarin mededeling werd gedaan wan de ontslagaanvraag van Marchant en diens bedanken voor het lidmaatschap van de VDB. Rooms zijn, kan nog net, maar rooms worden...

12. Rogier/De Rooy, In vri/held herboren, blz. 634.

13. Gribling. Nolens, blz. 145.

14. Ibid., blz. 141.

15. Ibld., blz. 149.

16. Puchinger, a.w., biz. 645 .

17. Oud, Het jongste verleden 111, blz. 123.

18. Puchinger, a.w. blz. 738.

19. ARA/KDC, archief Ruys.

20. Ibld.

21. Puchinger, a.w., blz. 805.

22. ARA/KDC, archief Ruys.

23. Gribling, Aalberse, blz. 442.

24. Puchinger, a.w., blz. 841.

25. KDC, archief RKSP, notulen katholieke kamerclub XII d.d. 17-09-1929.

\section{HOOFDSTUK 8}

1. Puchinger, Nederlandse politici, blz. 111 .

2. Oud, Het jongste verleden IV, blz. 136.

3. Puchinger, Colitn en het einde van de coalitie II, blz. 808 .

4. Oud, a.w., blz, 32.

5. Ibid., blz. 33.

6. Vigl. hlervóór, biz. 9.

7. ARAKDC, archlef Ruys.

8. Donner, Bestuursrecht 1, blz. 168.

9. Schurgers, Charles Ruys, blz. 53.

10. Oud, a.w., blz. 238.

11. Ibld., blz. 85.

12. Ibld., blz. 81.

13. Gemeentewet, editie Schuurman \& Jordens, $30^{\text {ste }}$ druk, Memorie van Toelichting wijzigingswet 1931, ad artikel 216.

14. Van der Pot, Staatsrecht, blz. 638.

15. Ubid., blz. 22 .

16. Keynes, "Economlc Possibilities for our Grandchlldren" , blz. 29-30.

17. Churchill, Memoires, dl. 1, blz, 33. 
18. In 1941 stelden de nazi's zo'n central punt, het Rijksarbeidsbureau, in en misbruilkten het voor de Arbeitseinsatz, de gedwongen tewerkstelling van Nederlanders in Duitsland.

19. Oud, a.w., ble. 136.

20. Pitlo, Verbintenissenrecht Il, blz. 395.

21. Van Nispen tot Sevenaer, "Balans van ruim 25 jaar pachtrecht", blz. 171-176.

22. Van Raalte, Het Nederlandse parlement, $2^{\mathrm{de}}$ druk, blz. 86.

23. Vgl. hlervóór, blz. 120-121.

24. Oud, a.w., blz. 102.

25. Van Raalte, a.w., blz, 167.

26. Oud, a.w., blz. 104.

27. Ubid., blz. 104; Van Raalte, a.w., blz. 170.

28. De resolutie van het SDAP-congres van 1928 is verkort weergegeven op blz. 105 van het a.w. van Oud.

29. Oud, a.w., blz. 112.

30. ARA/KDC, archieff Ruys.

31. libid.

32. Rogier/De Rooy, In viijheid herboren, blz. 455.

33. "Ich habe mir Sie zum Vorbild genommen.", vertrouwde de Oostenrijkse prlesterbondskanselier Ignaz Seipel Nolens in 1929 toe. "Was dat maar waar geweest", reageerde Nolens, "dan waart ge nooit minnister geworden." (KDC, archlef Nolens).

34. Puchinger, Nederlandse politici, blz. 65.

35. Puchinger, Colijn en het einde van de coalitie II, bliz. 552.

36. ARA/KDC, archlef Ruys.

37. Handelingen Tweede Kamer 1931-1932, biz. 3-4.

38. ARAKDC, archief Ruys.

39. Handelingen Tweede Kamer $1931-1932$, blz. 832.

40. Rogier/De Rooy, a.w., blz. 733.

41. ARAKDC, archief Ruys.

42. Ibid.

43. Van Nispen tot Sevenaer in Weekblad van het recht, nr. 12525.

44. Oud, a.w., blz. 364 .

45. Handelingen Tweede Kamer 1932-1933, blz. 313 e.v.

46. Puchinger, Nederlandse politici, blz. 316. In ziln memolres noemt Johan Schaper, een van de Twaalf Apostelen, de spreekkoren die zich op de $8^{\text {ste }}$ november 1932 lieten horen "smakeloos en de SDAP" onwaardig".

47. Comelissen, "Tegen het fascisme", blz. 148-155.

48. Oud, a.w. blz. 380 .

49. Gribling, Aalberse, blz. 456.

50. Oud, a.w. blz. 376.

51. Van Spanning, De Christelijk-Historische Unie, blz, 268.

52. Van Raalte, a.w., blz. 84-85. Er heerste grote ontstemming over het stemgedrag wan de dissidente katholieke senatoren. Drie van hen waren kort daarop aan de beurt van aftreden en werden daarom niet herkozen.

53. Vermeld in De Gelderlander wan 4 februarl 1999 in een artikel gewild aan het overiljden van Ruys' oudste dochter, aan wie deze anekdote wordt toegeschreven.

54. Vellenga, Katholiek Zuid-Limburg en het fascisme, biz. 69.

55. Van den Berg, "De Minister-President", biz. 97-125.

56. Oud, a.w., blz. 302. 


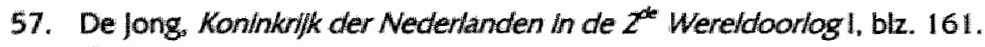

58. Oud, a.w., dl. V, blz. 2.

59. Cornelissen, "Het koloniallsme", blz, 138.

60. Oud, a.w., di. V., blz. 4.

61. BankNos, Hendirikus Cotijn, blz. 102.

62. De Jong, a.w., blz. 165.

63. Comellssen, "Het koloniallsme", blz. $138-139$.

64. Kranenburg/vegting, Inleiding in het Nederlands administratriefrecht, blz. 107-108; Van der Pot, a.w., blz. 459-460. Heringa/Zwart, Grondwet 1983, blz. 26 e.v.: Om wetgeving Inzake "ambtenaar en grondrechten" te laten voldoen aan de grondwettelijke beperkingssystematiek die tot formele wetgeving verplicht, ziln bil wet van 20 april 1988 , Statatsblad, nr. 229, de artikelen 125 a $\mathrm{t} / \mathrm{m}$ e in de ambtenarenwet ingevoegd.

65. KDC, dagboek Aalberse X 05-12-1932.

66. Van Spanning, a.w., blz. 221.

67. ARAKDC, archief Ruys.

68. Buys, de Gronctwet, dl. I, blz. 304.

\section{HOOFDSTUK 9}

1. Kesper over Ruys in het herdenkingsnummer van de Katholieke Illustratle

2. Het "zakboekje van Jhr. Ruys" in het herdenkingsnummer van de Katholieke Illustratie

3. Handellingen Tweede Kamer 1934-1935, blz. 2128 e.v.

4. Ibld., blz. 2195 e.v.

5. Ibld., blz. 2232 e.v.

6. Handelingen Tweede Kamer 1935-1936, blz. 2 e.v.; Oud. Het jongste verleden V.

7. blz. 230-231.

8. Archief Dagblad de Limburger.

9. Collin over Ruys in het herdenkingsnummer wan de Katholleke Illustratie.

10. ARAKDC, archlef Ruys.

11. Puchinger, Ontmoetingen met Nederlandse politict, blz. 11 .

12. Rogier/De Rooy, In vritheld herboren, blz. 473.

13. Fasseur, Wihelmina, blz. 541 .

14. Romeln, J., Erfaters van onze beschaving, blz. 772.

15. $\mathrm{Vgl}$. voetnoot 13 van hoofdstuk 1 .

16. $\mathrm{Vgl}$. voetnoot 52 van hoofdstuk 8 . 


\section{LEVENSLOOP VAN RUYS}

1873

$1892-1895$

1896

1899

$1899-1918$

1900

1902

$1905-1918$

1910

1914

1918

1918-1922

$1922-1925$

$1925-1929$

$1926-1929$

1927

1929-1933

$1933-1936$

1935

1936
Geboren in Roermond op 1 december

Rechtenstudie in Leiden

Advocaat in Maastricht

Voorzltter wan Sobrietas

Gemeenteraadslid van Maastricht

Rechtskundig adviseur van de RK Volksbond

Gehuwd met jkww. M. J. E. A. van der Heijdlen

Lid van de Tweede Kamer

Voorzitter van het Limburgse Groene Kruis

Regeringscommissarls voor hulp aan Belgische vluchtelingen

Commissaris der Koningin in Limburg

Eerste kabinet-Ruys

Tweede kabinet-Ruys

Voorzltter van de Tweede Kamer

Voorzitter van de RKSP

Minister van Staat

Derde kabinet-Ruys

Voorzitter van de Tweede Karner

Voorzitter van het Wit-Gele Kruis

Voorzitter van de Adelbertvereniging

Overleden in Utrecht op 17 april 


\section{BIJLAGE 2}

\section{KABINETTEN IN DE PERIODE 1918-1937}

\section{Ruys I (9 september 1918 - 18 september 1922)}

Binnenlandse zaken

Justitie

Onderwils, kunsten en wetenschappen

Financièn

Arbeld

Landbouw, niverheid en handel

Waterstaat

Oorlog

Marine

Buitenlandse zakem

Kolonlën
Jhr. mr. Ch. I. M. Ruys de Beerenbrouck mr. Th. Heemskerk

dr. J. Th. de Visser

mr. S. de Vries (tot 28-07*1921)

Ihr. mr. D. J. de Geer

mr. P.J.M. Aalberse

H. A. van Ijsselsteiln

ir. A. A. H. W. König

Ihr. G. A. A. Alting von Geusau (tot 05-01-1920)

Ruys (a.i. tot 31-03-1920)

W. F. Pop (tot 28-07-1921)

dr. J. I. C. van Dijk

W. Naudin ten Cate (tot 20-02-1919)

Ruys (a.l. tot 17-04-1919)

mr. H. Billeveld (tot 05-01-1920)

Van Ijsselisteljn (a.i. tot 31-03-1920)

Pop (a.l. tot 28-07-1921)

Van Dijk (a.l.)

Jhr. dr. H. A. van Karnebeek

A. W. F. Idenburg (tot 13-11-1919)

$S$. de Graaff

\section{Ruys II (18 september 1922 - 4 augustus 1925)}

Binnenlandse zaken en landbouw

Justitlie

Onderwijs, kunsten en wetenschappen

Financièn

Arbeid, handel en niverheid

Waterstaat

Oorlog

Marine

Buitenlandse zaken

Koloniën thr. mr. Ch. I. M. Ruys de Beerenbrouck mr. Th. Heemskerk dr. I. Th. de Visser jhr. mr. D. I. de Geer (tot 11-08-1923) dr. H. Colinn mr. P. J. M. Aalberse

ir. G. I. van Swaay dr. J. I. C. van Dijk E. P. Westerveld thr. dr. H. A wan Karnebeek S. de Graaff 


\section{Colijn I (4 augustus 1925 - 8 maart 1926)}

Binnenlandse zaken en landbouw

Justitle

Onderwijs, kunsten en wetenschappen

Financiên

Arbeid, handel en nijverheid

Waterstaat

Oorlog

Marine

Bulterilandse zaken

Kolonièn
Thr. mr. D. J. de Geer

dr. I. Scholkking

mr. V.H. Rutgers

dr. H. Colijn

mr. D. A. P. N. Koolen

ir. M. C. E. Bongaerts

J. M. J. H. Lambooy

Lamboay (a.l.)

Ihr. dr. H. A. van Karnebeek

Ch. J. I. M. Welter

\section{De Geer I (8 maart 1926 - 10 augustus 1929)}

BInnenlandse zaken en landbouw

Justitie

Onderwils, kunsten en wetenschappen

Flnanciën

Arbeid, handel en nliverheid

Waterstaat

Oorlog (tot 01-09.1928)

Marine (tot 01-09-1928)

Defensle (wanaf 01-09-1928)

Bultenlandse zaken

Kolonlë̀n mr. J. B. Kan

mr. J. Donner

mr. M. A. M. Waszink

jhr. mr. D. J. de Geer

dr. I. R. Slotemaker de Bruine

mr. H. van der Vegte

J. M. J. H. Lambooy (tot O1-09-1928)

Lambooy (tot 01-09-1928)

Lambooy (vanaf 01-09-1928)

Jhr. dr. H. A. van Karnebeek

(tot O1-04-1927)

thr. mr. F. Beelaerts van Blokland

dr. I. C. Koningsberger

\section{Ruys III (10 augustus 1929 tot 26 mei 1933)}

Binnenlandse zaken en landbouw

(tot 01.05-1932)

Binnenlandse zaken (vanaf 01-05-1932)

justitie

Onderwijs, kunsten en wetenschappen

Financlën

Arbeid, handel en nifverheld (tot 01-05- 1932)

Economische zaken en arbeld

(vanaf 01-05-1932)

Waterstatat

Defensle

Buitenlandse zaken

Koloniën jhr. mr. Ch. I. M. Ruys de Beerenbrouck (tot 01-05-1932)

Ruys (vanaf ol -05-1932)

mr. I. Donner

mr. I. Terpstra

Ihr. mr. D. J. de Geer

mr. T. J. Verschuur (tot 01-05-1932)

Verschuur (vanaf 01-05-1932)

mr. P. ]. Reymer

dr. L. N. Deckers

fhr. mr. F. Beelaerts van Blokland

S. de Graaff 
Colijn IV/II (26 mel 1933 - 31 jull 1935; na reconstructie: 31 jull 1935 tot 24 juni 1937)

Binnenlandse zaken

Justitie

Onderwijs, kunsten en wetenschappen

Financiën

Sociale zaken

Economische zaken (tot 02-09-1935)

Handel, nijuerheidl en scheepwaart

(vanaf 02-09-1935)

Landbouw en visseri) (vanaf 02-09-1935)

Waterstaat

Defensie

Buitenlandse zaken

Koloniën

mr. J. A. de Wilce

mr. J. R. H. van Schaik

mr. H. P. Marchant (tot 17-05-1935)

dr. J. R. Slotemaker de Bruïne

mr. P. I. Oud

dr. J. R. Slotemaker de Bruine

(tot 31-07-1935)

mr. M. Slingenberg.

mr. T. 1. Verschuur (tot 17-04-1934)

mr. M. P. L. Steenberghe (tot 06-06-1935)

dr. ir. H. C. J. H. Gelissen (tot 02-09-1935)

Gelissen (vanaf 02-09-1935)

dr. L. N. Deckers (vanaf 02-09-1935)

ir. J. A. Kalff (tot 13-O1-1935)

Ihr. Ir. O. C. A. van Lidth de jeude

dr. L. N. Deckers (tot 02-09-1935)

dr. H. Collin (a.l.)

jhr. mr. A. C. D. de Graeff

dr. H. Colign 


\section{SUMMARY}

\section{CHARLES RUYS DE BEERENBROUCK nobleman-statesman}

Charles joseph Marie Ruys de Beerenbrouck is born on December $\mathbb{1}, 1873$ in Roermond, a provincial town in the south of the Netherlands and birthplace of three Dutch prime ministers.

He grows up in a respectable Roman Catholic and well-to-do familly of nobility, living nevertheless in a sober style and practising "noblesse oblige". His father Gustave Ruys, a governor and politician with an open eye for the "social question", brought to pass in 1889 - a period in which state responsibility for the well-being of the individual and the community was still exceptional - the first llabour law of our country. From his father and mother Charles inherits religious zeal, humanity and sense of justice: qualities that generate the source of power for his social and political drive in the future.

Charles Ruys goes to the high school in Maastricht and The Hague, followed by his study of law at the University of Leiden. After his graduation in 1895 he establishes himself as a lawyer in Maastricht.

Years of great social and political engagement arrive. Also thanks to his initiative Roman Catholic trade unions and health institutions are founded in Maastricht and in many other places in the province of Limburg. At the same time he is active as a pioneer in the field of the alcohol temperance movement and the rehabilitation of discharged prisoners.

Next to that, from 1899 on till nineteen years later he is a progressive member of the city council in Maastricht, a function which he combines with his membership of the Lower Chamber (de Tweede Kamer) of parliament from 1905 till 1918.

In May 1918 Charles succeeds his father as Royal Commissioner in the province of Limburg. Four months later queen Wilhelmina requests him to form a new cabinet, based on the Christian Democratic parties. And on September 9, 1918 he is the first Catholic ever to be appointed prime minister in the - so far by conservatives, liberals and protestants dominated - parliamentary history of the Netherlands. 
Charles Ruys is one of the most prominent Dutch statesmen during the interbellum. Up to his death in 1936 he serves three times in turn as prime minister (1918-1922, 1922-1925 and 1929-1933) and twice as chairman of the Lower Chamber (1925-1929 and 1933-1936).

The years between 1918 and 1936 when Ruys plays such an important part in Dutch politics, for sure haven't been the most peaceful and trouble-free times in the twentieth age: the final fight of the first world war with its aftermath of misery; the revolutionary turbulences in November 1918 , dropped in from Germany; the disarmament rage with its paralysing effects on the national defence; the laborious process of the social and constitutional reform; the rise of fascism and national socialism; the economic decline and crisis in the twenties and thirties.

Thanks to his sound judgement, communication abilities, binding force and iron optimism Ruys is the right man to manage the public affairs in this turbulent period. Sometimes by trial and error, but always persisting with the toughness of a survival artist who isn't impressed by "a little turbullence at home".

It is the seventeenth of April $\mathbb{1 9 3 6}$ when a dangerously ill Ruys sighs:

"I can't live without working. I would rather wish God allows me to come". A bit later the nobleman-statesman who works for the people dles. Looking back on Ruys' political live we may conclude that he proved himself as a confidence inspiring, incorruptible governor and a firm promoter of the social constitutional state during the unstable interbellum. And that's anything but ordinary! 


\section{PERSONENREGISTER}

Aalberse, P.J.M. 2, 30-32, 36, 37, 42 . $47,51-55,67,71,80,81,86,100$, $104,105,109,110,113,127,129$, $139,147,164,166,167,176-179$, $184,192,197,199,201,203-205$, $207,208,210-212,215$

Aengenent, J.D.J. 133, 134

Agt, A.A.M. van 207, 208

Albarda. J.W. 73 137, 159, 162, 177, 182,185

Albrecht, aartshertog landvoogd 29

Alting von Geusau, jhr. G.A.A. 36, 38, 63, 66,215

Andel, J. van 199

Andeweg, R.B. 198

Anema, A. 206

Ariëns, A.M.A.]. 31

Bank, J.T.M. 198, 201, 212

Banning. W. 198, 205

Beel L.J.M. 68, 199

Beelaerts van Blokland, ihr. F. 117-119. $139,140,216$,

Benedictus XV. paus 90

Bentinck, G.J.Ch. graaf 39

Berg. J.Th.J. van den $198,205,212$

Bergh, G. van den 152, 180, 198, 208

Billeveld, $H$. 64, 215

Bllt, C.L. van der 154

Bomans, I.B. 63, 66, 111

Bongaerts, M.C.E. 216

Boon, Giu, 150, 184, 187

Bos, D. 17,18

Bosmans, J. 201, 202, 207

Bouman, P.J. 198

Bovend'Eert, P.P.T. 198, 200, 207

Braakenslek. I. 55

Brlnkel, Th.B.F.M. 198

Bronsweld-Vitringa, S.C.C. 111

Bruijn. J. de 198

Buys, $\rrbracket$.Th. 124, 185, 198, 212

Calvilin, 1. 127, 149

Charlté, J. 198
Churchill, W.L.S. 126, 153, 198, 211

Clemenceau, G. 51,210

Collin, H. 2, 22, 23, 25, 26, 36, 64, 66, $67,85,87,88,92,93,98,99,109$ $111,117-122,125-127,129-131$. 133, 137, 139, 140,146,154, 165, $170,176,179,182,185,186,189$. $191-193,204-207,209,210,212$. 215-217

Cornelissen, I. 198, 211, 212

Cornips, J. 198, 203

Cort van der Linden. P.W.A. 1, 17, 18, $24,63,75,83,90,103,119,145$, 192,205

Couperus, L.M.A. 127, 209

Cramer, Ch.G. 182

Cranenburgh, R.Ch.A. van 133

Deckers, L.N. $140,159,160,182,216$, 217

Derks, M. 198, 203

Diepenhorst, P.A. $156-158$

Dilk, J.J.C. van $70,71,109,122,129$, $150,159,160,193,215$

Domela Nieuwenhuis, F.). 15,44

Donner, A.M. 68, 147, 198, 202, 205$207,209,2110$

Donner, J. 140, 147, 156-158, 184, 216

Dorhout Mees, T.J. 198

Drees, W. 201

Dresselhuys, H.C. $42,99,147$

Drucker, W. 57

Ebels, F.E.H. 157, 158, 174

Ebert. F. 38

Elzinga, D.J. 198

Emma, koningln-moeder 139

Fasseur, C. 195, 198, 207, 208, 212

Fillips 11, koning van Spanje 29

Fleskens, A.N. 156-158, 174

Fortanier, G.F. 199, 202, 208 
Geer, jhr. D.f. de $26,27,62,70,87-89$, 95, 98, 100, 101, 108, 110, 128, $134-137,139,140,144,145,149$, $154-156,159,165-167,169,170$, $176,177,179,197,206,207,215$, 216

Gelissen, H.C.J.H. 217

Giebels, L.J. 199

Glin, A. van 137

Goeman Borgesius, H. 15, 16, 20

Goseling, C.M.J.F. 180

Gosses, I.H. 199

Graaff, S. de 107, 140,205, 215, 216

Graeff, jhr. A.C.D. de 217

Gribling. J.P. 28, 70, 134, 178, 199, 203$208,210,211$

Grinten, I.H.P.M. van der 209

Groen van Prinsterer, G. 10

Groeneweg, S. 44, 207

Handy, Ch. 199

Harmsen, G. 199, 205

Hasseit. W.J.C. van 199

Heemskerk, J. 8, 12, 102

Heemskerk, Th. 1, 17, 20, 23, 25, 26, 35 , $47,50,69,86,89,101-104,106$,

$109,124,127,129,132,137,147$. $162,174,184,215-217$

Heringa, A.W. 199, 205, 212

Hitler, A. 143

Hoeven, I. van der 199, 208

Houten, S. van 13,19, 20

Huizinga. J.J. 207

Idenburg, A.W.F. 23, 25, 26, 35, 48, 66. 205,215

IJsselsteyn, H.A. van 36, 64, 215

Isabella, aartshertogin-landvoogdes 29

Jacobs, A. 57

Japikse, N. 199

Jong, L. de $71,72,199,205,206,212$

Kalff, I.A. 217

Kan. J.B. 216

Kappeyne van Coppello. 1. 6, 11, 12,57

Kappeyne van Coppello ir., J. 206
Karnebeek Thr. H.A van 30, 36, 71, 72, $81,91,119,120,126,129,135$. $136,215,216$

Kersten, G.H. 85, 122, 131, 132, 134, $137,148,193$

Kesper, LA. 191, 212

Ketelaar, Th.M. 57

Keymes, J.M. 153, 186, 199, 211

Kimman, E.J.J.M. 30, 199, 203

Klompe, M.A.M. 199

Knottenbelt, $H_{2}$. $\|77\|$,

Kolkman, M.J.C.M. 16

Könlg, A.A.H.W. 36, 215

Koningsberger, I.C. 216

Koolen, D.A.P.N. 110, 115-117, 119, $130,133,216$

Kortmann, C.A.J.M. 199

Krabbe, $H, 77,124,147$

Kranenburg, R. 146, 158, 196, 199, 209. 212

Krol, Ch.B, 199

Kuiper, D.Th. 199

Kummeling, H.R.B.M. 200

Kuyper, A. 1, 11, 14-16, 21, 22, 24, 25, $27,28,35,46,54,77,94,102$, $108,130,139,147,201,202,205$. 210

Lambooy. |M.).H. 216

Leo XIII, paus 200, 204

Lidth de jeude, O.C.A. van 217

Limburg, J. 134, 165

Lingbeek, C.A. 148, 149, 151, 168, 206

Loder, B.C.J. 71

Lokin-Sassen, P. 203

Lowink . H.). 153, 170

Lubbers, R.F.M. 1, 2, 94, 199, 201

Lynden van Sandenburg, C.Th. baron van 184

MacDonald, J.R. 153

Mackay, Ae. baron 6, 13, 20, 29, 198, 199

Marchant, H.P. 2, 42-44, 48, 56, 57, 63, $69,78-80,86,99,114,116,124$, $125,132,134,137,145-147,152$. $160,162,167,185,191,196,210$. 217

Marx, K.H. 44, 50, 198 
Meester, Th. H. de 159

Melfers, E.M. 199

Miler, P. 8

Minkenhof, A. 199, 208

Molengraaff, W.L.P.A. 104

Monté verLoren, F.H. de 92

Mussolinl, B. 111

Naudin ten Cate, W. $36,63,66,215$

Nlezen, 1. 199

Nispen tot Sevenaer, |hr. C.C.C.M. van 203

Nispen tot Sevenaer, Jhr. C.M.O. wan 33, $157,175,199,210,211$

Nispen tot Sevenaer-Ruys de Beerenbrouck, |kww. M.J.A. van 2, 32, 198, 211

Nispen tot Sevenaer, Jhr. O.F.A.M. van $25,26,42,58,68,120,128,165$, 166,206

Nolens, W.H. 1, 20, 22-28, 31, 36, 56, $60,66,67,69,70,72,76,80,81$, $86,87,89,91-94,99,109,111$. $120,124,128-132,134,140,146$. 151, 164-166, 196, 199, 201-207, 209-211

Oppenheim, J. 124, 151

Ort, B. 103

Ould, P.J. 28, 50, 57, 58, 68, 72, 76, I\|1, $122,150,170,171,180,199,201$, 202, 204-212, 217

Pacelli, E. kardinaal 203

Peters, I.A.) 199

Pkerson, N.G. 15, 20

Pitlo, A, 156, 199, 208, 211

Ploeg, P.W. van der 199

Poels, H.A. 201

Pop, W.F. 62-65, 68, 82, 215

Post, R. 199

Postma, A. 198

Pot, C.W. van der 68, 152, 183, 199 , 202, 205-210

Prakke, L. 199

Puchinger, G. 2, 28, 58, 109, 200-212

Ralte, E. van 68, 119,200, 201, 205 . $206,209,211$
Ravesteil $n_{*}$ W. wan 58, 11

Reede, I.L. de 199

Regout, P.D. 30

Reymer, P.J. 140, 149, 150, 216

Rinik. P. 69

Rogier, L.J. 164, 195, 200, 202, 205. 210-212

Romelin, 1. 2, 200, 212

Romein-Verschoor, A. 2, 200

Rood, M.G. 200

Rooy, N. de 21, 133, 200, 202, 205. $210-212$

Rossini, G. 57

Rutgers. V.H. 68, 78, 99, 116, 209, 216

Ruys, Gerlach 29

Ruys de Beerenbrouck, Jhr. G.A.M.I. 32, 33, 203, 204

Ruys de Beerenbrouck-barones de Loé, M.M.C.Ph.H.G. 33

Ruys de Beerenbrouck, thr. G.L.M.H. 20 , $29,30,33,53,120,195,199,203$, 204

Ruys de Beerenbrouck-Ruys de Beerenbrouck, jkww. M.I.L. 29, 33, 120

Ruys de Beerenbrouck-jkww. van der Heijden, M.J.E.A. 32, 214

Ruys de Beerenbrouck, jkww. L.M.E.A. 29. 30

Ruys van Beerenbroek, jhr. E.H. 29

Ruys van Beerenbroek-van Aefferden, C.M.A.Ph. 29

Sasse van IIsselt, Jhr. A.F.O. van 78

Savornin Lohman, Jhr. A.F. de 1, 13,14, $21-23,25,26,56,58,60,68,80$, $81,87,88,117,124,130,139,210$

Schaepman, H.|.A.M. 11,13-16, 21, 22 , $36,132,195,201,202$

Schaepman, Th.F.M. 164, 165

Schalk, J.R.H. van 75, 78, 111-116, 160 . 191,217

Schaper, J.H.A. 43. 54,69, 105, 159 ,

$160,206,211$

Scheffer, H.J. 200, 204, 205

Scheidemann, Ph, 38

Schenk, M.G. 200

Schermerhorn, W. 46

Schimmelpenninck. G. graaf 5 
Schokking. I. $78,87,88,92,93,99,104$ 。 $116,132,137,146,151,179,216$

Scholtens, L.A. 52

Schurgers, H.J.H. 200, 201, 210

Seipel, I, 211

Shakespeare, W. 146

Slingenberg, M. 217

Slotemaker de Bruïne, J.R. 55, 136, 148 . 216,217

Sluis, W. van der 156, 157

Smeets. M.K.J. 203

Snijders, C.I. 38

Solinge, A.G. van 199

Spanning, H. van 200, 202, 211, 212

Steenbeek, J.G. 200, 202, 208

Steenberghe, M.P.L. 191, 217

Streek, $H_{\text {. }}$ van de 200,204

Stroink, F.A.M. 200, 202, 208

Struycken, A.A.H. 30, 106, 183, 206, 208

Swaay, G.J. van $97,97,215$

Tak van Poortvllet, J.P.R. 12-15

Talma, A.S. $20,27,37,52-54,65,136$

Terpstra, J. 140,168, 216

Thorbecke. J.R. 5, 6, 7, 9, 19, 36, 77, 83, $147,151,201$

Tilanus, H.W. $114,143,159,160,194$

Tjeenk Willink, H.D. 206

Toirkens, S.J. 200, 208

Treub, M.W.F. 48

Trip, L.J.A. 27

Troelstra, P.J. 1, 15, 17, 38-45, 50, 76-79, $87,99,110,111,115,116,124,165$

Vegte, $H$. van der 216

Vegting, W.G. 183, 199, 200, 209, 212

Vellenga, S.Y.A. 200, 212

Veraart, J.A. 133, 134

Veraart, I.J.M. 199, 202, 210

Verhagen, J.A.H. 28, 200, 203

Vermeulen, H. 200, 202, 210

Verschudur, T.J. 55, 140,148, 149, 154-156, $164,170-172,180,181,186,197,216$. 217

Visscher, H. 48

Visser, 1.Th de $14,23,35,57,58,69,81$, $100,109,122,127,129,134,174,215$
Visser, L.L.H. de 160,162,176, 193

Visser van I|zendoorn. A.C. 78

Vliegen, W.H. 79, 135, 183

Vogt, W. 149

Voorst tot Voorst, I.I.G. Laron wan (18461931) 130

Voorst tot Voorst, IIJ.G. Baron wan (1880 1963) 33

Voorst tot Voorst-Ruys de Beerenbrouck. J.M.A.L. van 32

Vorrink, J.J. 183

Vos, C. $198,201,212$

Vos van Steenwijk, W.L. baron de 79,176

Vries, S. de $27,36,61,62,65,67,81,82$. 215

Waal Malefijt. I.H. de 208

Wareham, J. 200, 205

Waszink, M.A.M. 216

Welter, Ch.J.1.M. 167, 168, 172, 186, 216

Westerman, J. 151, 207

Westervell, E.P. 95, 97, 122

Wieland, I.H.M. 200

Wijnbergen, A.I.M.J. baron van 24, 83, 137, 206

Wilnen, H.A. van 200

Wijnkoop, D.J. 176

Wilde, I.A. de 217

Wilhelm II, keizer van Dultsland $38,39,51$

Wilhelmina, koningin $17,24,27,33,45,48$, $49,57,68-70,75,82,86-88,90,97$. $102,115-119,127,137,139,141,175$, $195,198,200,207,208,212$

Willem II, koning 6

Willem III, koning 8

Wissen, G.J.M. van 199

Zuylen van Njevelt, 1,P.]. A. graal van 8

Zwart, T. 199, 212 


\section{C.v.}

Jo Stassen (Beek, 1936) volgde van 1949 tot 1955 het gymnasium op het Bisschoppelijk College in Sittard. Studeerde vervolgens rechten aan de Universiteit van Amsterdam en slaagde daar, na een onderbreking wegens militaire dienst, in 1964 voor het doctoraal examen in de publiekrechtelijke richting.

Werkte vervolgens zes jaar in een wet- en regelgevende functie bij de gemeente Amsterdam en switchte in 1970 naar de rijksdienst, waar hij zich achtereenvolgens bij financiën en VROM bezighield met grondzaken en automatisering. Was ten slotte van 1980 tot aan zijn vervroege uittreding medio 1997 successievelijk directeur van het kadaster en de openbare registers in Friesland en Limburg.

Hem was het na afsluiting van zijn beroepsbezigheden een must zich onder begeleiding van de Universiteit Maastricht te verdiepen in de roerselen van lemand die niet kon leven zonder te werken. Dochter Caroline hielp hem zijn bevindingen op papier te zetten. 